Flavia d'Albuquerque Andrade da Silveira

\title{
Cenários urbanos: construindo identidades através de uma arquitetura temática
}

Tese apresentada como requisito parcial para obtenção do grau de Doutora pelo Programa de Pós-Graduação em Arquitetura e Urbanismo da Universidade de São Paulo -Área de concentração Projeto, espaço e cultura.

Orientador Prof. Dr. Carlos Roberto Zibel Costa 
Autorizo a reprodução e divulgação total ou parcial deste trabalho, por qualquer meio convencional ou eletrônico, para fins de estudo e pesquisa, desde que citada a fonte.

flaviadalbuquerque@terra.com.br

Ficha Catalográfica

Silveira, Flavia d'Albuquerque Andrade da Silveira

S587c Cenários urbanos: construindo identidades através de uma arquitetura temática / Flavia d'Albuquerque Andrade da Silveira. --São Paulo, 2009.

209 p. : il.

Tese (Doutorado - Área de Concentração: Projeto, Espaço e Cultura) - FAUUSP.

Orientador: Carlos Roberto Zibel Costa

1.Arquitetura 2.Espaço urbano 3.Espaço turístico I.Título

CDU 72 
Para Marcelo e Felipe 


\section{Agradecimentos}

Ao meu orientador, Professor Carlos Zibel, pelo estímulo e parceria para a realização deste trabalho.

À Capes e à USP, pelos auxílios concedidos, sem os quais este trabalho não poderia ter sido realizado.

Ao Marcelo, por tudo.

Aos meus pais, Antonio e Angela, pela educação, atenção, apoio e incentivo de sempre.

À Vó Vilma, por ter me apresentado a arte.

Aos amigos da FAU-UFRJ.

Aos professores que participaram da Comissão Examinadora.

A todos os professores e funcionários da FAU USP pelos ensinamentos e pela ajuda.

A todos os amigos e familiares que, de uma forma ou de outra me estimularam ou me ajudaram. 
Resumo No último século, a inserção de temas explorados segundo características figurativas, alegóricas e narrativas tornou-se freqüente em locais voltados para comércio e lazer. Estes chamados Espaços Temáticos encontram paralelo em cidades que, visando o turismo, passaram a adotar elementos do modelo temático em escala urbana. Este trabalho procura identificar as possibilidades de utilização do temático no espaço urbano, associando-o ao marketing de lugar. Além disso, relaciona reflexos do temático na produção arquitetônica contemporânea, como a utilização do figurativo, mas, especialmente, o caráter espetacular que permeia a arquitetura atual.

Palavras-chave Arquitetura; Marketing de lugar; Espaços Temáticos; Cidades Temáticas; Turismo; Cenografia; Arquitetura promocional 
Abstract Throughout the last century, the inclusion of themes exploited according to figurative, allegorical and narrative characteristics, has become frequent in commercial and leisure oriented places. These so called Themed Places find similarities in cities that, aiming for tourism, adopt elements of the theme formula in urban scale. This research intends to identify different possibilities on theming urban space, according to place marketing. Also, it finds reflexes of the theme formula in contemporary architectural production, such as the use of figurative, but most of all, the exploitation of spectacle present in nowadays architecture.

Key-words Architecture; Place Marketing; Themed Places; Themed Cities; Tourism; Cenography; Promotional Architecture. 


\section{Lista de figuras}

\section{Capa 1.Veneza-acervo pessoal}

2.Venus Fort Shopping, Tóquio - www.venusfort.co.jp

3.Hotel The Venetian, Macau - www.venetianmacao.com

4.Itália em EPCOT Center - acervo pessoal

5.Hotel The Venetian, Las Vegas - www.thevenetian.com

6.Barra World Shopping - acervo pessoal

Capítulo 1 1.Pintura paleolítica - GOMBRICH, E. H. A Historia da Arte. Rio de Janeiro: LTC, 1999. p.41.

2.Pintura mural em Pompéia - acervo pessoal

3.Colunas em Pompéia - acervo pessoal

4.Coluna em Pompéia (detalhe) - acervo pessoal

5.Maquete da Vila Adriana - acervo pessoal

6.Canopus, Vila Adriana - acervo pessoal

7.Escultura de Crocodilo na Vila Adriana - acervo pessoal

8.Portal da Catedral de Chartres - GYMPEL, Jan. Histoire de l'Architecture. De l'Antiquité a nos Jours. Köln: Könemann, 1997. p.35

9.Sala dos espelhos em Versalhes - GYMPEL, Jan. Histoire de l'Architecture. De l'Antiquité a nos Jours. Köln: Könemann, 1997. p.57

10.Strawberry Hill - www.wmf.org.uk

11.Castle Ward - www.discovermotherireland.com

12.Castle Ward - www.discovermotherireland.com

13.Neuschweinstein - GYMPEL, Jan. Histoire de l'Architecture. De l'Antiquité a nos Jours. Köln: Könemann, 1997. p.74

14.Edifício projetado por Adolf Loos - GYMPEL, Jan. Histoire de l'Arcbitecture. De l'Antiquité a nos Jours. Köln: Könemann, 1997. p.83

15.Worlds Columbian Exposition - www.columbia.edu

16.Plan voisin - www.architecture.com

17.Ville Radieuse - www.architecture.com

18.Pavilhão L'Esprit Nouveau - GÖSSEL, Peter. e LEUTHÄUSER, Gabriele. Arquitectura no século XX. Köln: Taschen, 1996. p.167

19.Pavilhão L'Esprit Nouveau (interior) - GÖSSEL, Peter. e LEUTHÄUSER, Gabriele. Arquitectura no século XX. Köln: Taschen, 1996. p.166

20.Life Style, de Bruce Mau - www.archrecord.construction.com

21.Suporte para canetas aerodinâmico - www.lepoix.de

22.Moedor de gelo aerodinâmico - www.lepoix.de

23.Kitsch - vendedor de souvenirs - www.common.wikimedia.org

24.Kitsch - anões de jardim - www.baixaki.ig.com.br

25.Kitsch - domos de neve - www.collectibles.about.com

26.Kitsch religioso - acervo pessoal

27.Desenho animado "Pluto's Dream House" - DUNLOP, Beth. Building a Dream: The Art of Disney Architecture. New York: Harry N. Abrams Publisher, 1996. p.18

28.Projeto para entrada de Disneyland - DUNLOP, Beth. Building a Dream: The Art of Disney Architecture. New York: Harry N. Abrams Publisher, 1996. p.19

29.Glass House, de Philip Johnson - GYMPEL, Jan. Histoire de l'Arcbitecture. De l'Antiquité a nos Jours. Köln: Könemann, 1997. p.95.

30.Procuratie Vecchie - BOTTON, Alain de. Arquitetura da Felicidade. São Paulo: Editora Rocco, 2007. p.186.

31.Palácio do Doge - BOTTON, Alain de. Arquitetura da Felicidade. São Paulo: Editora Rocco, 2007. p.187.

32.Villa Savoye - GÖSSEL, Peter. e LEUTHÄUSER, Gabriele. Arquitectura no século XX. Köln: Taschen, 1996. p.172.

33.Chenonceau - www.chenonceau.com

34.Strip durante o dia - www.commons .wikimedia.org 
35.Strip durante a noite - www.commons.wikimedia.org

36.Placa do hotel-cassino Caesar's - VENTURI, Robert, SCOTT BROWN, Denise, IZENOUR, Steven. Learning From Las Vegas - The Forgotten Symbolism of Architectural Form. Cambridge: The MIT Press, 2001. p.60

37.Placa recente do hotel-cassino Caesar's - www.commons.wikimedia.org

38.Placa de entrada em Las Vegas - www.commons.wikimedia.org

39.Placa do hotel-cassino Circus circus - www.commons.wikimedia.org

40.Luxor - www.casinofolk.com

41.Excalibur - www.casinofolk.com

42.Luxor interior - www.las-vegas-hotel-price.com

43.Excalibur Interior - www.las-vegas-hotel-price.com

44.Caesar's: shopping interno - www.city-data.com

45.Caesar's: piscinas - www.city-data.com.br

46.Edifício-pato - VENTURI, Robert, SCOTT BROWN, Denise, IZENOUR, Steven. Learning From Las Vegas - The Forgotten Symbolism of Architectural Form.

Cambridge: The MIT Press, 2001. p.88

47.Sinalização para sanitátio em Colonial Williamsburg - www.history.org

48.Colonial Williamsburg - www.history.org

49.Colonial Williamsburg - www.history.org

50.Colonial Williamsburg - www.history.org

51.Colonial Williamsburg - www.history.org

52.Huis Ten Bosch - www.jnto.go.jp

53.Shijingshan - www.i.abcnews.com

54.Freemont Street - HUXTABLE, Ada Louise. The Unreal America Architeture and Illusion. The New Press. New York:1993. p.77.

55.Batalha de piratas em Treasure Island - www.treasureisland.com

56.Quincy Market - www.city-data.com

57.West Edmonton Mall - www.westedmall.com

58.Barra World Inglaterra - acervo pessoal

59.Barra World Japão - acervo pessoal

60.Barra World Holanda - acervo pessoal

61.Disney Village - DUNLOP, Beth. Building a Dream: The Art of Disney Architecture. New York: Harry N. Abrams Publisher, 1996. p.164.

62.Disney Village - DUNLOP, Beth. Building a Dream: The Art of Disney Architecture. New York: Harry N. Abrams Publisher, 1996. p.163.

63.Marilyn, Andy Warhol - ARGAN, Giulio Carlo. Arte Moderna. São Paulo: Companhia das Letras, 2002. p.649.

64.Hotel Swan - DUNLOP, Beth. Building a Dream: The Art of Disney Architecture. New York: Harry N. Abrams Publisher, 1996. p.69.

65.Hotel Dolphin - DUNLOP, Beth. Building a Dream: The Art of Disney Architecture. New York: Harry N. Abrams Publisher, 1996. p.72.

66.Close-up progressivo do pavilhão Marrocos, em EPCOT Center - THE IMAGINEERS. Walt Disney Imagineering - A Bebind the Dreams Look at Making the Magic Real. New York: Disney Editions, 1996. p.158.

67.Close-up progressivo do pavilhão Marrocos, em EPCOT Center - THE IMAGINEERS. Walt Disney Imagineering - A Bebind the Dreams Look at Making the Magic Real. New York: Disney Editions, 1996. p.159.

68.Close-up progressivo do pavilhão Marrocos, em EPCOT Center - THE IMAGINEERS. Walt Disney Imagineering - A Bebind the Dreams Look at Making the Magic Real. New York: Disney Editions, 1996. p.159.

\section{Capítulo 2 1.All Star Cafe Nova York - acervo pessoal}

2.All Star Cafe na Disney World - www.disney.go.com

3.All Star Sports - acervo pessoal

4.All Star Sports - DUNLOP, Beth. Building a Dream: The Art of Disney Architecture. New York: Harry N. Abrams Publisher, 1996. p.185.

5.All Star Sports - acervo pessoal

6.All Star Sports - acervo pessoal 
7.All Star Sports - acervo pessoal

8.All Star Music - DUNLOP, Beth. Building a Dream: The Art of Disney Architecture. New York: Harry N. Abrams Publisher, 1996. p.189.

9.All Star Music - DUNLOP, Beth. Building a Dream: The Art of Disney Architecture. New York: Harry N. Abrams Publisher, 1996. p.189.

10.Cite de La Musique - www.cite-musique.fr

11.Hard Rock Café Las Vegas - acervo pessoal

12.Hard Rock Cafe Cancun - acervo pessoal

13.TheAmerican Adventure - acervo pessoal

14.TheAmerican Adventure - acervo pessoal

15.Parthenon de Nashville - www.nashville.gov

16.Estátua da liberdade - www.nps.gov

17.Estátua da liberdade em New York City Center - acervo pessoal

18.Copacabana Lounge - DUNLOP, Beth. Building a Dream: The Art of Disney

Architecture. New York: Harry N. Abrams Publisher, 1996. p.74.

19.Blizzard Beach - quadro de idéias - THE IMAGINEERS. Walt Disney

Imagineering - A Bebind the Dreams Look at Making the Magic Real. New York: Disney Editions, 1996. p.26.

20.Blizzard Beach - acervo pessoal

21.Blizzard Beach - acervo pessoal

22.Blizzard Beach - acervo pessoal

23.Hopi Hari - www.hopihari.com.br

24.Pleasure Island - projeto - THE IMAGINEERS. Walt Disney Imagineering - $A$ Behind the Dreams Look at Making the Magic Real. New York: Disney Editions, 1996. p.23.

25.Pleasure Island - atual - THE IMAGINEERS. Walt Disney Imagineering - $A$ Behind the Dreams Look at Making the Magic Real. New York: Disney Editions, 1996. p.183.

26.Ingresso Disneyland - acervo pessoal

27.Animatronics - THE IMAGINEERS. Walt Disney Imagineering - A Bebind the Dreams Look at Making the Magic Real. New York: Disney Editions, 1996. p.91.

28.Animatronics - confecção - THE IMAGINEERS. Walt Disney Imagineering - $A$ Bebind the Dreams Look at Making the Magic Real. New York: Disney Editions, 1996. p.125.

29.Guapo Loco - acervo pessoal

30.Hidden Mickey - www.hiddenmickeys.org

31.Team Disney Building - DUNLOP, Beth. Building a Dream: The Art of Disney Architecture. New York: Harry N. Abrams Publisher, 1996. p.85.

32.Restaurante de Team Disney Building - DUNLOP, Beth. Building a Dream: The Art of Disney Architecture. New York: Harry N. Abrams Publisher, 1996. p.88.

33.Projeto inicial para Disneyland - THE IMAGINEERS. Walt Disney Imagineering - A Bebind the Dreams Look at Making the Magic Real. New York: Disney Editions, 1996. p.14.

34.Projeto para Disneyland - DUNLOP, Beth. Building a Dream: The Art of Disney Architecture. New York: Harry N. Abrams Publisher, 1996. p.28.

35.Folder do parque Six Flags Magic Mountain, com os personagens da Warner Brothers - acervo pessoal

36.Islands of adventure - acervo pessoal

37.Islands of adventure - acervo pessoal

38.Islands of adventure - acervo pessoal

39.Disney Village - acervo pessoal

40.Folder de City Walk Hollywood - acervo pessoal

41.City Walk Orlando - acervo pessoal

42.Disney Village - DUNLOP, Beth. Building a Dream: The Art of Disney Architecture. New York: Harry N. Abrams Publisher, 1996. p.164.

43.Disney Village - DUNLOP, Beth. Building a Dream: The Art of Disney Architecture. New York: Harry N. Abrams Publisher, 1996. p.165.

44.Disney Store - THE IMAGINEERS. Walt Disney Imagineering - A Bebind the Dreams Look at Making the Magic Real. New York: Disney Editions, 1996. p.185. 
45.NBA store - acervo pessoal

46.NBA City - acervo pessoal

47.Solvang - www.solvangusa.com

48.Solvang - www.solvangusa.com

49.Estátua de Jack Daniel em Lynchburg - www.jackdaniels.com

50.Big Apple, em Colborne - www.americansguide.ca

51.Telefone público em Sidrolândia - www.sidrolandia.ms.gov.br

52.Telefone público em Pirapora - www.guipirapora.com.br

53.Telefone público em Porto de Galinhas - www.portodegalinhas.com.br

54.Telefone público em Salvador - acervo pessoal

Capítulo 3 1.Chichen Itzá - som e luz - www.cancunvista.com

2.Chichen Itzá - som e luz - www.cancunvista.com

3.Serpente reproduzida em Chichen Itzá - AROCHI, Luis E. La pirâmide de

Kukulcán: su simbolismo solar. Octava reimpresión corregida y actualizada. Anzures: Panorama Editorial, 1992. p.82.

4.Chichen Itzá no equinócio - AROCHI, Luis E. La pirâmide de Kukulcán: su simbolismo solar. Octava reimpresión corregida y actualizada. Anzures: Panorama Editorial, 1992. Contracapa.

5.Projeto para queima de fogos - OECHSLIN, Werner, BUSCHOW, Anja. Architecture de Fête. Bruxelles: Pierre Mardaga editeur, 1984.

6.Queima de fogos em comemoração ao tratado de Aix-la-Chapelle OECHSLIN, Werner, BUSCHOW, Anja. Architecture de Fête. Bruxelles: Pierre Mardaga editeur, 1984.

7.Empire state iluminado para o Natal - www.commons.wikimedia.com 8.Empire state iluminado para o Valentine's Day - www.commons.wikimedia. org

9.Queima de fogos no Magid Kingdom - DUNLOP, Beth. Building a Dream - The Art of Disney Architecture. New York: Harry N. Abrams Publisher, 1996. p.42.

10.Show de lasers na Universal Studios - Folder do parque

11.Queima de fogos em Pleasure Island - Folder do parque

12.Grande Arché - www.grandearche.com

13.Arco de Sobral - www.sobral.ce.gov.br

14.Arco de Sobral - www.sobral.ce.gov.br

15.Arco de triunfo no folder da Universal Studios - acervo pessoal

16.Arco de triunfo em MGM Studios - acervo pessoal

17.Capitólio - Washington - www.commons.wikimedia.org

18.Lincoln Memorial - Washington - www.washington.org

19.Casa branca - Washington - www.commons.wikimedia.com

20.Brasília - Palácio do Congresso - GYMPEL, Jan. Histoire de l'Architecture. De l'Antiquité a nos Jours. Köln: Könemann, 1997. p.99.

21.Brasília - Palácio do planalto - BRUAND, Yves. Arquitetura Contemporânea no Brasil. São Paulo: Editora Perspectiva, 2002. p.195.

22.Brasília - Bloco residencial - BRUAND, Yves. Arquitetura Contemporânea no Brasil. São Paulo: Editora Perspectiva, 2002. p.210.

23.Cupom promocional para Capone's dinner show - www.orlandocuponsfree. com

24.Cupom promocional para Arabian nigths - www.orlandocuponsfree.com 25.Cupom promocional para Pirate's dinner adventure - www. orlandocuponsfree.com

26.Mapa de Walt Disney World - www.disney.go.com

27.Sky Venture - www.skyventure.com

28.Gatorland - www.gatorland.com

29.Wonder Works - www.wonderworksonline.com

30.Show de som e luz em Freemont Street; Las Vegas - www.commons. wikimedia.org

31.Show de som e luz em Freemont Street; Las Vegas - www.commons. wikimedia.org 
32.Show de som e luz em Freemont Street; Las Vegas - www.commons. wikimedia.org

33.Rio All-Suite Hotel \& Casino - www.lasvegas-hotel-casino-reviews.com

34.Paris Las Vegas - www.lasvegas-hotel-casino-reviews.com

35.Circus circus - www.commons.wikimedia.org

36.Treasure Island - www.treasureisland.com

37.Show no Museu imperial - www.museuimperial.gov.br/someluz

38.Show no Museu imperial; Petrópolis - www.museuimperial.gov.br/someluz

39.Show no Museu imperial; Petrópolis - www.museuimperial.gov.br/someluz

40.Show de som e luz em Carcassone - www.carcassone.org

41.Show de som e Luz no Red Fort - www.indiantouristguide.com

42.Show de som e luz em Keops - www.touregypt.net

43.Garrafa de Coca-cola antiga - folder do museu

44.Museu da Coca-cola - acervo pessoal

45.Main Street - DUNLOP, Beth. Building a Dream - The Art of Disney Architecture. New York: Harry N. Abrams Publisher, 1996. p.118.

46. Main Street - DUNLOP, Beth. Building a Dream - The Art of Disney Architecture. New York: Harry N. Abrams Publisher, 1996. p.119.

47.Calico Ghost Town - www.calicotown.com

48.Calico Ghost Town - www.calicotown.com

49.Seaside - KATZ, Peter. The New Urbanism Toward an Architecture of Community. McGraw Hill, Inc.1994.

50.Seaside - KATZ, Peter. The New Urbanism Toward an Architecture of Community. McGraw Hill, Inc.1994.

51.Seaside - KATZ, Peter. The New Urbanism Toward an Architecture of Community. McGraw Hill, Inc.1994.

52. “O show de Truman” - cena do filme

53.Celebration - Vista aérea - www.commons.wikimedia.org

54.Celebration - rua - acervo pessoal

55.Projeto de Epcot - THE IMAGINEERS. Walt Disney Imagineering - A Bebind the Dreams Look at Making the Magic Real. New York: Disney Editions, 1996. p.37

56. Modelo de residência em Celebration: Colonial revival - LARA, Fernando. Admirável Urbanismo Novo. In. Arquitextos - periódico mensal de textos de arquitetura (online) Disponível: http://www.vitruvius.com.br

57.Modelo de residência em Celebration: Coastal - LARA, Fernando. Admirável Urbanismo Novo. In. Arquitextos - periódico mensal de textos de arquitetura (online) Disponível: http://www.vitruvius.com.br

58.Modelo de residência em Celebration: Victorian - LARA, Fernando. Admirável Urbanismo Novo. In. Arquitextos - periódico mensal de textos de arquitetura (online) Disponível: http://www.vitruvius.com.br

59.Modelo de residência em Celebration: Classical - LARA, Fernando. Admirável Urbanismo Novo. In. Arquitextos - periódico mensal de textos de arquitetura (online) Disponível: http://www.vitruvius.com.br

60.Panorama da área central de Celebration - www.commons.wikimedia.com

61.Praça em Celebration - acervo pessoal

62.Cinema em Celebration - acervo pessoal

63.Edifício comercial em Celebration - acervo pessoal

64.Residências em Celebration - acervo pessoal

65.Via secundária para veículos em Celebration - acervo pessoal

66.Via de serviço para pedestres em Celebration - acervo pessoal

Capítulo 4 1.Coleção Moranguinho-ALZER, André e CLAUDINO, Mariana. Almanaque anos 80. Rio de Janeiro: Ediouro, 2004. p.259.

2.Ursinhos Carinhosos - www.voceselembra.com

3.He-Man - ALZER, André e CLAUDINO, Mariana. Almanaque anos 80. Rio de Janeiro: Ediouro, 2004. p.260.

4.Caderno da Branca de Neve - www.americanas.com.br

5.Boneca Branca de Neve - www.americanas.com.br 
6.Bolsa da Branca de Neve - www.americanas.com.br

7.“A Branca de Neve” - cena do filme

8.Davy Crockett - http://daniel-boone.blogspot.com

9.Brinquedos Kinder Ovo - acervo pessoal

10.Shampoo do Cocoricó - www.paodeacucar.com.br

11.Shampoo da Angélica - www.paodeacucar.com.br

12.Shampoo da Disney - www.paodeacucar.com.br

13.Hamburguer da Mônica - www.paodeacucar.com.br

14.Extrato de tomate do Jotalhão - www.paodeacucar.com.br

15.Fralda da turma da Mônica - www.fraldaemcasa.com.br 16.Propaganda de Vedacit com Cascão - www.vedacit.com.br

17.Boneco Lost - www.lostbrasil.com

18. Boneco Lost - www.lostbrasil.com

19.Boneco Lost - www.lostbrasil.com

20.Grande piano na FAO Schwarz - www.fao.com

21.Toys R'Us - acervo pessoal

22.Toys R'Us - acervo pessoal

23.Website da Ryan Air - www.ryanair.com

24. Logo de Paty do Alferes - www.patydoalferes.ri.gov.br

25.Holambra - www.holambra.sp.gov.br

26.Holambra - www.holambra.sp.gov.br

27.Holambra - www.turismoholambra.com.br

28.Holambra - www.turismoholambra.com.br

29.Logo I love New York - www.iloveny.com

30.Salzburg - acervo pessoal

31.Salzburg - ônibus do "The sound of music tour" - acervo pessoal

32. Estádio olímpico de Tianjin - www.oglobo.globo.com

33. Estádio Nacional Indoor; Pequim - www.oglobo.globo.com

34. Centro Aquático Nacional; Pequim - www.oglobo.globo.com

35. Parque Olímpico Shunyi; Pequim - www.oglobo.globo.com

36. Estádio Olímpico de Shenyang - www.oglobo.globo.com

37. Ginásio do instituto de Tecnologia - www.oglobo.globo.com

38. Estádio Nacional - festa de encerramento - www.oglobo.globo.com

39. Logo Turquia - www.tourismturkey.org

40. Logo Tailândia - http://amazingthailand.tourismthailand.org

41. Logo Texas - www.travel.state.tx.us

42. Logo Suíça - www.myswitzerland.com

43. Logo Costa Rica - www.visitcostarica.com

44. Logo Singapura - www.visitsingapore.com

45. Logo Áustria - www.austriatourism.com

Capítulo 5 1.Tomorrowland antes - DUNLOP, Beth. Building a Dream - The Art of Disney Architecture. New York: Harry N. Abrams Publisher, 1996. p.134.

2.Tomorrowland antes - DUNLOP, Beth. Building a Dream - The Art of Disney Architecture. New York: Harry N. Abrams Publisher, 1996. p.134.

3.Tomorrowland depois - DUNLOP, Beth. Building a Dream - The Art of Disney Architecture. New York: Harry N. Abrams Publisher, 1996. p.133.

4.Tomorrowland depois - DUNLOP, Beth. Building a Dream - The Art of Disney Architecture. New York: Harry N. Abrams Publisher, 1996. p.133.

5.Aladdin - www.lasvegashotelreservation.org

6.Planet Hollywood - www.las vegastourism.com

7.Safári no Animal Kingdom - acervo pessoal

8.Animais animatronics no Magic Kingdom - www.disneyworld.disney.go.com

9.Chopp de vinho - www.oautentico.com.br

10.Suco com gominhos - www.minutemaid.com.br

11.Barra World - mundo árabe - acervo pessoal 
12.Barra World - mundo árabe - acervo pessoal

13.Veneza - acervo pessoal

14.Veneza - The Venetian - www.thevenetian.com

15.Veneza - Barra World - acervo pessoal

16.Palio em Siena - www.ilpaliodisiena.org

17.Medieval Times - www.medievaltimes.com

18.Dachau - vista geral - acervo pessoal

19.Dachau - alojamento - acervo pessoal

20.Guggenheim em Bilbao - JODIDIO, Philip. Contemporary American Architects. Volume IV. Köln: Taschen, 1998. p.63.

21.Burj Dubai - www.burjdubai.com

22.Taj Mahal - GYMPEL, Jan. Histoire de l'Architecture. De l'Antiquité a nos Jours. Köln: Könemann, 1997. p.19.

23.Centro Pompidou - GÖSSEL, Peter. e LEUTHÄUSER, Gabriele. Arquitectura no século XX. Köln: Taschen, 1996. p.324.

24.Opera House de Sidney - www.commons.wikimedia.org

25.Zaragoza - Viagem e Turismo - Especial - Isto é Espanha, edição 151-E

05/2008. São Paulo: Editora Abril p.34.

26.Logo da cidade de Niterói - www.niteroi.ri.gov.br

27.MAC Niterói - www.macniteroi.com.br

28.Souvenir de Innsbruck - acervo pessoal

29.Ski Jump em Innsbruck - acervo pessoal

30.Funicular em Innsbruck - acervo pessoal

31.Torre de Montjuïc - CERVER, Francisco Asensio. The World of Contemporary Architecture. Cologne: Könemann, 2000. p.107.

32.Troféu do grande prêmio da Espanha - www.daylife.com

33.Burj Al Arab - www.burj-al-arab.com

34.Dancing Towers - www.dubaicityguide.com

35.The Palm - www.thepalm.ae

36.The World - www.theworld.ae

37.Piazza d'Italia - GÖSSEL, Peter. e LEUTHÄUSER, Gabriele. Arquitectura no século XX. Köln: Taschen, 1996. p.270.

38.Chiat/Day - JODIDIO, Philip. Formes Nouvelles. Köln: Taschen, 1997. p.159.

39.Puente de la Mujer - www.commons.wikimedia.org

40.Puente de la Mujer - http://archrecord.construction.com/projects/bts/ archives/bridges/04_puentaMujer/overview.asp

41.Sala de degustação em López de Heredia - www.dezeen.com

42.Sala de degustação em López de Heredia - www.dezeen.com

43.Centro de Cultura Judaica - http://culturajudaica.uol.com.br

44. Hotel Holyday Inn Resort Gagudju Crocodile - FRAUSTO, Salomon. OCKMAN, Joan. (org). Architourism Authentic Escapist Exotic Spectacular. Prestel. New York: 2005. p.93.

45.Agência dos correios em Celebration - acervo pessoal

46.Escultura em La Vilette - www.worldvisitguide.com

47.Escultura em La Vilette - www.worldvisitguide.com

Conclusão 1.American Center - www.vitruvio.ch

2.Disney Concert Hall - www.laphil.org 


\section{Sumário}

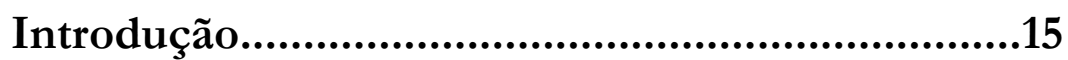

Capítulo 1 - Conceitos fundamentais.....................23

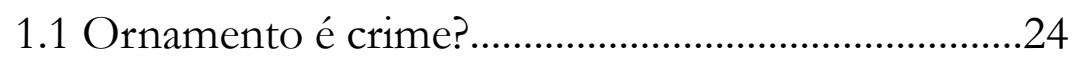

1.2 Styling e Kitsch: respostas precoces

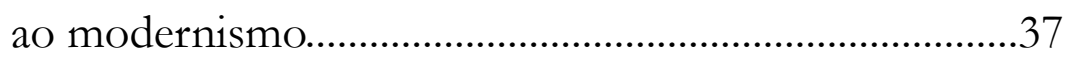

1.3 Venturi e o simbolismo na arquitetura.........................42

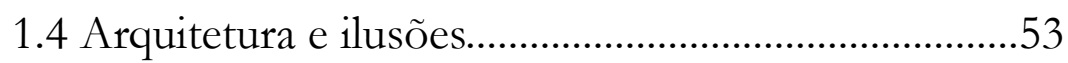

1.5 Conceitos contemporâneos............................................62

Capítulo 2 - Entendendo o temático........................70

2.1 Espaços Temáticos........................................................70

2.2 Cidades Temáticas.............................................................

Capítulo 3 - O tema no espaço urbano....................98

3.1 Poder e tema..............................................................99

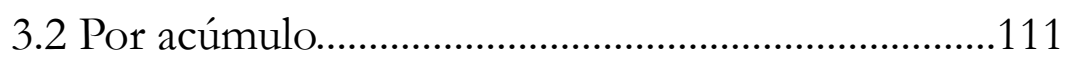

3.3 História e tema.........................................................117

3.4 Temáticas e assumidas..............................................123

Capítulo 4 - Marketing e tema..............................137

4.1 Marketing na cultura visual contemporânea...........137

4.2 Marketing de lugar e turismo........................................150

Capítulo 5 - Tema e arquitetura na cultura contemporânea .....................................................166

5.1 Identidade e autenticidade........................................166

5.2 Temático no contexto da arquitetura contemporânea................................................................184

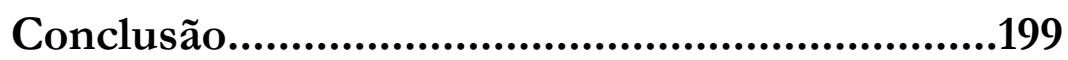

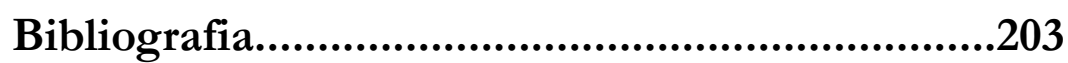




\section{Introdução}

Este trabalho foi resultado de uma série de questionamentos surgidos durante a elaboração da dissertação de mestrado "Design, cenografia e entretenimento - uma análise da evolução dos Espaços Temáticos", defendida em abril de 2004, pelo departamento de Artes e Design da Pontifícia Universidade Católica do Rio de Janeiro. A pesquisa em questão tratava, resumidamente, da inclusão de um tema norteador da concepção arquitetônica, explorado de maneira alegórica, figurativa e narrativa, como meio de atrair o consumidor para estabelecimentos de comércio e lazer. A proposta foi, então, construir uma reflexão que buscasse identificar as características comuns aos estabelecimentos que se propõem temáticos, bem como as causas para o surgimento deste modelo de entretenimento, ou seja, o processo que desencadeou esta prática.

Ao longo do trabalho, ficou claro que este processo não se restringia a parques temáticos ou a estabelecimentos estritamente comerciais, embora obedecesse à ótica mercadológica. Se foram estudadas situações em que a identidade corporativa era construída a partir de uma ambientação temática, surgiu a indicação para o desdobramento proposto como pesquisa de doutorado, a partir do momento em que se identificou que um processo análogo de construção de imagem através do temático poderia se estender ao marketing de cidades.

Portanto, esta pesquisa tem como objeto de estudo o que podemos chamar, em analogia aos Espaços Temáticos, de Cidades ou Regiões Temáticas. Em primeiro lugar, é preciso deixar claro que não se trata de um trabalho sobre parques temáticos, tampouco sobre a Disney. Certamente, estes são os paradigmas que norteiam a exploração do temático e, como tais, serão estudados e, freqüentemente, mencionados como referências. Contudo, o que se busca aqui é o entendimento sobre a transição da exploração alegórica da arquitetura dos parques para estabelecimentos comerciais e culturais diversos e, enfim, para o espaço urbano.

Igualmente, o trabalho se propõe a identificar as influências do modelo temático na arquitetura produzida nos 
últimos anos, buscando comprovar que há reflexos do modelo temático na produção arquitetônica contemporânea. Mais do que simplesmente tratar do local em si, a pesquisa enfoca a relação estabelecida entre a arquitetura alegórica, narrativa, de apreensão imediata, enfim, temática, e a construção da identidade local. A reflexão proposta versa sobre a maneira como uma exploração temática de determinada região pode contribuir para alterar tanto sua identidade local quanto a imagem que ela divulga e deixa transparecer aos visitantes.

Certamente, será questionada a moralidade de um trabalho que trata de algo tão controverso quanto a indução de consumo, ainda que não seja este o enfoque da pesquisa. Quanto a isso, cabem alguns esclarecimentos. Conforme ocorrido na pesquisa de mestrado que originou esta proposta, não se pretende neste trabalho julgar positiva ou negativamente a incidência de representações cenográficas como base para os modelos arquitetônicos contemporâneos. Este seria, sem dúvida, o caminho mais óbvio e esperado, porém acredita-se aqui que rejeitar esta arquitetura, de alguma forma já incorporada à nossa cultura ocidental, seria mais artificial que assumir a existência e pertinência desta exploração mercadológica da paisagem em nosso tempo.

Ciente da polêmica gerada por esta temática, creio que torna-se necessário um posicionamento da pesquisadora diante do controverso objeto de estudo. Embora não seja o objetivo deste trabalho julgar a existência dos estabelecimentos temáticos ou sua influência na arquitetura contemporânea, fatalmente a pesquisa suscitará uma demanda por tal julgamento. Nesse sentido, falo aqui como pesquisadora, professora e acadêmica que busca entender o que está por trás do fenômeno, bem como as razões que o tornam tão polêmico, mas tento, igualmente, entender a perspectiva dos responsáveis pela divulgação e comércio dos estabelecimentos ou cidades temáticos. No entanto, falo, sem dúvida, como consumidora, parte de uma geração que cresceu tendo como sonho a viagem à Disney World, sem nunca enxergar no sonho a perversão do consumo. Falo como quem, ainda hoje, percorre Espaços Temáticos apreciando seu aspecto lúdico, deixando-se levar pela fantasia com naturalidade, sem perder a perspectiva de que se 
trata apenas de um momento de lazer.

Assim, ainda que mais fácil do ponto de vista acadêmico, seria de grande hipocrisia condenar indistintamente a utilização do modelo temático e o consumo, afinal somos todos consumidores, se não de produtos licenciados, de livros, filmes, músicas, etc. Enfim, cada vez mais também a cultura é um bem consumível, de maneira que, mesmo no meio acadêmico, desejamos consumir. Acredito que até o opositor mais ferrenho dos parques temáticos poderia ser seduzido por algum estabelecimento que explorasse tema de seu interesse. Para Bauman, o consumo (não o consumismo) pode ser encarado como “(...) um elemento inseparável da sobrevivência biológica que nós humanos compartilhamos com todos os outros organismos vivos".

O lazer é legítimo e necessário, e não me parece problemático que cada um busque, dentro dos limites éticos e legais, aquilo que lhe proporcione prazer, ainda que fugindo momentaneamente da realidade. É isso o que fazemos ao tomar um chopp ou um café com amigos e é o que fazemos ao curtir a fantasia proporcionada por Espaços Temáticos. Parece mais coerente com nosso tempo não promover oposição revolucionária contra o temático e o consumo, e sim aproveitá-los naquilo a que se destinam: lazer momentâneo e despretensioso, sem que isso signifique ignorar todos os problemas de nossa sociedade.

Portanto, em momento algum foi buscada uma "solução" para combater os Espaços Temáticos; muito pelo contrário, a intenção foi, antes de julgá-los, entendê-los. Assim, quanto aos questionamentos sobre a validade dos projetos estudados, pode-se dizer que, se por um lado, os Espaços Temáticos podem, através da imersão na fantasia, promover um consumo menos controlado e servir ao objetivo comercial, por outro, podem propiciar momentos de diversão despreocupada para os que se deixam levar consciente e momentaneamente por seu aspecto lúdico. Neste sentido, seria preciso questionar antes o objetivo dos empreendimentos voltados para o comércio e lazer, para só então questionar se "tematizar" estes espaços satisfaz suas necessidades.

Podemos contrapor as opiniões de Carlos e Klein. A 
primeira afirma que:

"A indústria do turismo transforma tudo o que toca em artificial, cria um mundo fictício e mistificado de lazer, ilusório, onde o espaço se transforma em cenário para o "espetáculo" para uma multidão amorfa mediante a criação de uma série de atividades que conduzem à passividade, produzindo apenas a ilusão de evasão, e, deste modo, o real é metamorfoseado, transfigurado, para seduzir e fascinar. Aqui o sujeito se entrega às manipulações desfrutando a própria alienação e a dos outros." 2

É fácil inserir a Disneyland ou outro parque temático assumidamente artificial neste modelo. Entretanto, a própria autora chama atenção para a criação de um comportamento construído para o turismo em cidades como Paris ou Nova York em que há um roteiro rápido e pré-determinado a ser seguido pelo passivo turista. $\mathrm{O}$ city tour passa pelos pontos que caracterizam a cidade, de acordo com o imaginário do turista, também construído pelo marketing. Diante desta constatação, podemos questionar se existe de fato alguma realidade, alguma autenticidade. A autora faz referência a guias turísticos de Nova York que deixam de mencionar espetáculos de balé, privilegiando o enfoque no comércio e consumo, por exemplo. Se a busca é por cultura e autenticidade, cabe a discussão: Seria o balé, culturalmente autêntico na cidade? Não seria o próprio consumo a grande característica do local? A questão aqui é: Não seria ainda mais artificial buscar um passado cultural com o qual a população de hoje não se identifica? E de que época buscaríamos tais referências? A mesma autora cita Eco, afirmando que "a Disney é a alegoria da sociedade de

3. ECO (1986) consumo"’3. Se, no cotidiano, há uma obrigação consumista para o turista, parece haver, na academia, uma obrigação de se negar o consumo. Talvez o caminho do meio seja o menos artificial.

Resgatar culturas parece tão poético quanto ingênuo. É mais fácil acreditar que o morador das pequenas cidades que exploram o temático objetivando o turismo deseja esta exploração como uma de chance de adquirir o direito ao consumo. Isto porque o desenvolvimento do turismo e, conseqüente- 
4. Editorial, Hermenaut \# 10: Popular Culture, 1995. In. KLEIN (2002) p.102.

5. BOTTON (2007) pp.72-73. mente, da economia local, pode trazer oportunidades para o morador. A retomada de uma suposta cultura local, sem identificação com a geração atual, leva a um contra-senso, pois carrega o potencial de transformar o local em uma espécie de parque temático construído artificialmente para o turismo.

A postura dita irônica, ao invés de combativa, de alguns jovens em relação à cultura de massa, onde se incluem, a princípio, os Espaços Temáticos, foi relatada por Naomi Klein citando o zine Hermenaut:

“(...) Ir ao Disney World para tomar ácido e sacanear o Mickey não é revolucionário; ir ao Disney World com pleno conhecimento de o quão ridículo e pernicioso é tudo aquilo e ainda viver grandes momentos de inocência, em alguns casos quase inconsciência, mesmo que psicótica, é algo completamente diferente. Isso é o que Certeau descreve como 'a arte de estar entre as coisas', e é o único caminho de verdadeira liberdade na cultura atual." ${ }^{4}$

A adoção desta proposta de consumo consciente do lazer, mais coerente e realista, permite uma análise menos preconceituosa sobre o temático. Alain de Botton mostra como nossa visão de mundo influencia a percepção sobre a arquitetura:

\begin{abstract}
“Descrever um prédio como belo (...) implica uma atração pelo estilo particular de vida que esta estrutura está promovendo (...). Sentir uma sensação de beleza é sinal de que encontramos uma expressão material de certas idéias que temos do que seja viver bem.

Similarmente, os prédios nos parecem ofensivos (...) porque conflitam com a nossa compreensão do justo sentido da existência - e isso nos ajuda a explicar a seriedade ou o caráter vicioso em que tendem a se desenrolar as disputas a respeito do papel da arquitetura." 5
\end{abstract}

Não seria, então, o desprezo pelo temático um reflexo do desprezo pelo consumismo que este representa? Há uma espécie de culpa associada ao consumo sendo transposta para o temático.

Cabe, ainda, esclarecer, inicialmente, a preponderância de exemplos norte-americanos dentre as referências citadas ao longo do trabalho. O fato se deve, em primeiro lugar, à cons- 
tatação de que foi nos Estados Unidos o surgimento do temático com objetivo comercial e é lá que, realmente, está a maior parte das referências. Além disso, há maior disponibillidade de fontes que citam a exploração do temático nos Estados Unidos e houve possibilidade de visita a alguns destes locais. A pesquisa procurou compensar esta predominância mencionando, sempre que possível, casos brasileiros e de outras partes do mundo, a fim de mostrar que, embora o foco inicial do temático tenha sido norte-americano, o modelo foi bastante difundido, fazendo parte de uma cultura global.

Em resumo, objetiva-se discutir a utilização de elementos temáticos na arquitetura e seu papel na construção de identidades locais, atingindo conclusões que propiciem seu entendimento, sem necessariamente combatê-los. O trabalho se propõe, ainda, a traçar uma relação entre este modelo e as arquiteturas do passado, de modo a contribuir para o entendimento sobre seu papel no contexto da arquitetura contemporânea.

Para tanto, o primeiro capítulo define um quadro teórico fundamental, buscando identificar e analisar o que foi dito pelos teóricos que, ao longo da história questionaram a presença do ornamento na arquitetura. Além disso, inclui teorias contemporâneas pertinentes ao estudo das cidades temáticas, como os conceitos de "colagem" e "montagem", de

6. MONTANER (2002)

7. PARENTE (2004)

8. LIPOVETSKY(2004)

9. MORIN (2000)

Montaner ${ }^{6}$, "rede", de Parente ${ }^{7}$, "hipermodernidade", de Lipovetsky $^{8}$ e "complexidade", de Morin". Esta reflexão teórica inicial pretende solidificar a base a partir da qual será possível, no decorrer do trabalho, avaliar a evolução do uso de temas na arquitetura e construção identitária.

O segundo capítulo retoma os Espaços Temáticos estudados durante a dissertação de mestrado defendida. Com isso, mostra como elementos figurativos ganharam destaque na arquitetura, especialmente em estabelecimentos voltados para o comércio e lazer. A primeira parte deixa clara a definição de Arquitetura Temática a ser adotada, mostrando como este modelo surgiu e se desenvolveu e comparando casos claramente temáticos com casos em que não há nenhum elemento alegórico, e outros em que o próprio programa se sobressai, tornase figurativo e acaba por converter-se em tema. Em seguida, 
tratará das chamadas Cidades Temáticas, procurando mostrar como o modelo temático transcendeu os estabelecimentos comerciais e passou a ser usado como elemento de construção de identidades locais e instrumento para o marketing das cidades, visando uma ampliação de seu potencial turístico.

O capítulo seguinte enfoca as principais implicações acarretadas pelo uso de temas na construção de identidades locais. Foram pesquisados casos emblemáticos e diferentes formas de exploração dos temas no espaço urbano, direta ou indiretamente. Assim, são apresentados casos de conversão da cidade em temática, segundo algumas possibilidade principais levantadas, bem como exemplos de situações precursoras, em que ainda não há o temático comercial e explícito. Teve enfoque a relação entre arquitetura e poder, pois foram relacionados casos em que a exploração do tema em diferentes níveis contribuiu igualmente para o desenvolvimento de identidades locais, a partir da imagem pretendida pelo governante responsável.

O quarto capítulo relaciona a questão ao marketing e turismo. Para isso, mostra como a cultura visual associada à busca contínua pelo lazer e o enfoque do marketing no público infantil podem ter contribuído para a consolidação do temático. Em seguida, analisa o marketing de lugar, segundo o qual o mercado turístico foi aquecido em função de uma exploração alegórica do espaço, pretendendo comprovar que, de um modo geral, o turista associa a cidade a símbolos que, explorados sob uma ótica figurativa e alegórica, são convertidos em tema. Entretanto, o capítulo identifica, também, a possibilidade de crescimento econômico decorrente da aplicação de técnicas de marketing a localidades.

O capítulo final pretende situar o modelo temático dentro do contexto da arquitetura contemporânea, relacionando-o à teoria recente da arquitetura. A primeira parte questiona os conceitos de 'identidade' e 'autenticidade', mostrando que o temático foi utilizado como estratégia de diferenciação, culminando com a cultura do fake, em que tudo começa a parecer igual. A estratégia atual para diferenciar o produto seria, então, procurar dotá-lo de caráter autêntico.

Finalmente, a segunda parte avalia que, se o temático 
faz cada vez menos sentido, por outro lado, há características do modelo que permeiam a produção arquitetônica contemporânea. Assim, a tese é concluída identificando elementos de relação entre o modelo temático e a arquitetura contemporânea, de modo a contribuir para sua inserção na teoria arquitetônica recente. 


\title{
Capítulo 1 Conceitos fundamentais
}

\begin{abstract}
"Parece que somos incapazes de olhar prédios ou móveis sem atá-los às circunstâncias históricas e pessoais das nossas observações; conseqüentemente estilos arquitetônicos e decorativos tornam-se, para nós, suvenires emocionais dos momentos e cenários nos quais os encontramos."1
\end{abstract}

Alain de Botton

Introdução

1. BOTTON (2007) p. 94
Este capítulo pretende contribuir para a avaliação da evolução e surgimento da Arquitetura Temática, estabelecendo uma revisão bibliográfica sob a crítica acerca do ornamento na arquitetura. Como é escassa a crítica que trata especificamente do temático, propõe-se relacionar autores e críticos que, de uma forma ou de outra, demonstraram preocupação com a presença, ausência e relevância do ornamento na arquitetura. Objetiva-se, assim, identificar momentos que contribuíram para o desenvolvimento atual da Arquitetura Temática e, ainda, constituir uma base sólida para a discussão posterior sobre a ética neste tipo de projeto e seu papel na arquitetura atual.

A proposta aqui é, portanto, mostrar como a alegoria, ainda que não assumidamente temática, está há tempos presente na arquitetura e como aparece hoje. Esta comprovação pode corroborar a tese de que, embora o temático não se enquadre especificamente em nenhum movimento arquitetônico, muito de sua essência permeou a história e muito permanece, tendo influenciado diretamente a arquitetura contemporânea. Pretende-se relacionar a presença e intensidade do ornamento e alegoria na arquitetura ao longo da história à existência recente do temático, revisando a crítica sobre a evolução do ornamento na arquitetura até o momento histórico em que o temático está no auge.

Este capítulo irá avaliar a crítica arquitetônica sobre o ornamento, culminando em conceitos contemporâneos aplicáveis ao modelo estudado. Com isso, será possível estabelecer uma reflexão buscando comprovar que o temático precede, de certa forma, várias características fundamentais presentes em grande parte da produção contemporânea, como a pre- 
ponderância da visualidade e o aspecto simbólico figurativo, fazendo pela cidade o que a arquitetura temática fez pelo estabelecimento comercial.

1.1 Embora não tenha sido possível documentar a primeiOrnamento é crime? ra aparição do termo 'Arquitetura Temática', a expressão está, indubitavelmente, relacionada ao surgimento dos primeiros parques temáticos, em especial do complexo Disneyland, inau2. DUNLOP (1996) p. 27 gurado em 1955. ${ }^{2}$ Se a Arquitetura Temática, assumida como tal, aparece somente no século XX, parece bastante provável que elementos ornamentais tenham aparecido na arquitetura desde seu início. Para estabelecer um debate sobre a presença e relevância do ornamento na arquitetura, poderíamos retroceder a ponto de, inclusive, retomar a discussão acerca das pinturas rupestres. Arnold Hauser ${ }^{3}$ defende a hipótese de que, durante o período paleolítico, em que o homem dependia da

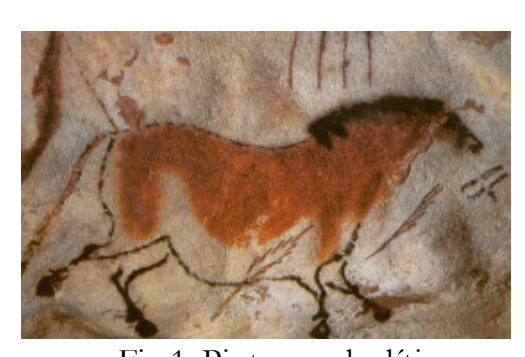

Fig 1. Pintura paleolítica em caverna; Lascaux, França. caça e coleta para sobrevivência, as pinturas teriam possuído caráter pragmático. A representação mimética da caça precedendo o ato funcionaria como garantia de seu sucesso, e qualquer interpretação da pintura como elemento ornamental mostra-se insustentável, já que os animais representados apareciam inevitavelmente flechados, antecipando o sucesso da caça.

Entretanto, Hauser aponta que, com a transição para o período neolítico, em que o homem passa a dominar o cultivo vegetal e domesticação do animal, fixando residência por temporadas mais longas, a representação pictórica mimética perde o sentido. A nova situação permite uma divisão de tarefas mais nítida e permite ao homem desenvolver um nível de abstração inédito. As representações pictóricas e escultóricas atingem um caráter simbólico, dividindo-se entre elementos de arte sacra ou ornamentação e podendo, então, funcionar

4. Idem pp. 9-17 como elementos estéticos. ${ }^{4}$ Ou seja, é possível que a caverna, esta forma primitiva de habitação, ainda que não projetada ou construída pelo homem, já recebesse acréscimos ornamentais. Embora não se pretenda aqui analisar a fundo esta questão, tampouco comprovar a hipótese de Hauser, a mera possibilidade de que o ornamento no espaço construído, ou neste caso, apropriado, estivesse presente em épocas tão remotas ressalta 
sua importância para o homem.

Seguindo um pouco adiante, podemos citar a argu5. ARGAN (1999) mentação de Giulio Carlo $\operatorname{Argan}^{5}$, defendendo uma relação entre os sucessivos períodos históricos, do ponto de vista estético, baseada na antítese entre clássico e anticlássico, em que, a partir da antiguidade clássica greco-romana, seguiriam momentos de repúdio e aceitação desta estética clássica original. Entretanto, embora o ornamento tenha sido, principalmente após o modernismo, notadamente associado ao anticlássico, identificamos, já durante o Império Romano, um apreço por elementos de composição exclusivamente ornamentais. Nas ruínas romanas de Pompéia, exemplos de sua aplicação são encontrados em pinturas murais ou em colunas erguidas com tijolos, porém ornamentadas para parecerem colunas clássicas de pedra. O próprio Coliseu de Roma fez com que os romanos fossem, em vários momentos, considerados desonestos, pelo acréscimo de colunas fingindo sustentar os pavimentos superiores, quando na verdade a estrutura dependia exclusivamente dos arcos.

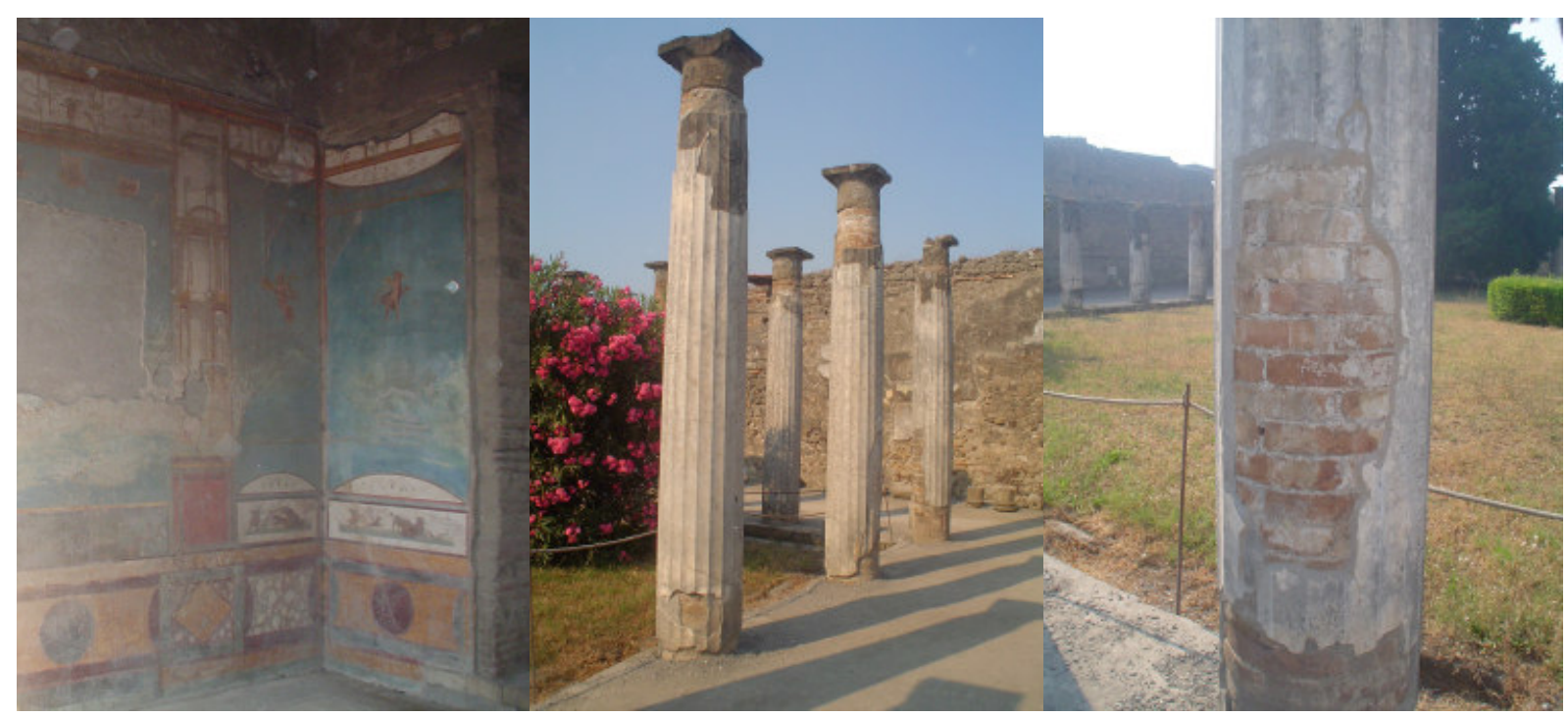

Figs 2, 3 e 4. Pintura mural em residência e colunas de tijolos revestidas para simular pedra; ruínas de Pompéia.

Conjuntos esculturais cenográficos são encontrados nas ruínas da Vila Adriana, construída no século II DC como residência de veraneio para o Imperador Adriano em Tívoli, nos arredores de Roma. A Vila possui escala urbana e, conforme veremos adiante, pode ser tratada como um dos primei6. Ver Capítulo 1.5 ros exemplos de colagem arquitetônica. ${ }^{6} \mathrm{Um}$ de seus setores, 
conhecido como Canopus, teria a pretensão de reproduzir o canal que ligava as cidades de Alexandria e Canopus, no Egito, configurando uma insipiente manifestação de Arquitetura Temática. Exemplificando a referência adotada para o projeto deste setor do complexo está o conjunto escultórico ainda preservado que inclui, entre outros, um crocodilo esculpido em

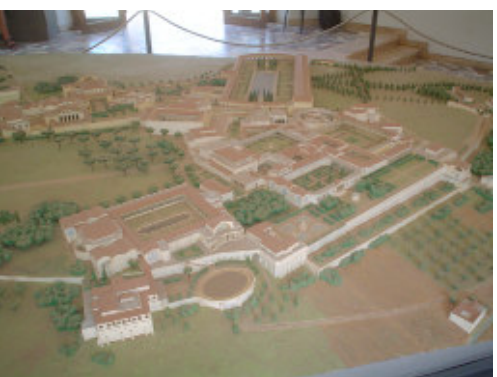

Fig 5. Reconstituição em maquete da Vila Adriana; Tívoli, Itália.

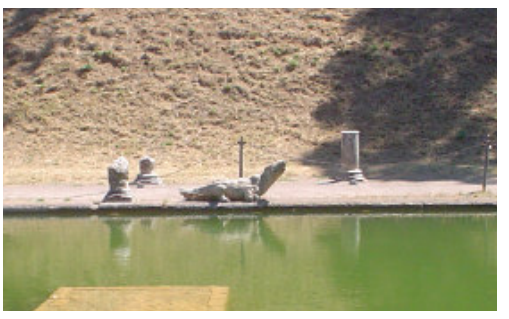

Fig 7. Escultura de crocodilo, na Vila Adriana.

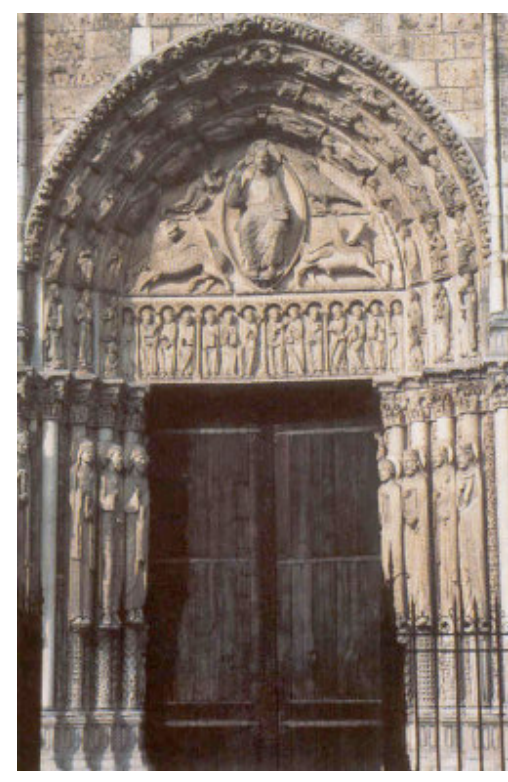

Fig 8. Portal da Catedral de Chartres; França. pedra, referência figurativa ao tema adotado. ${ }^{7}$

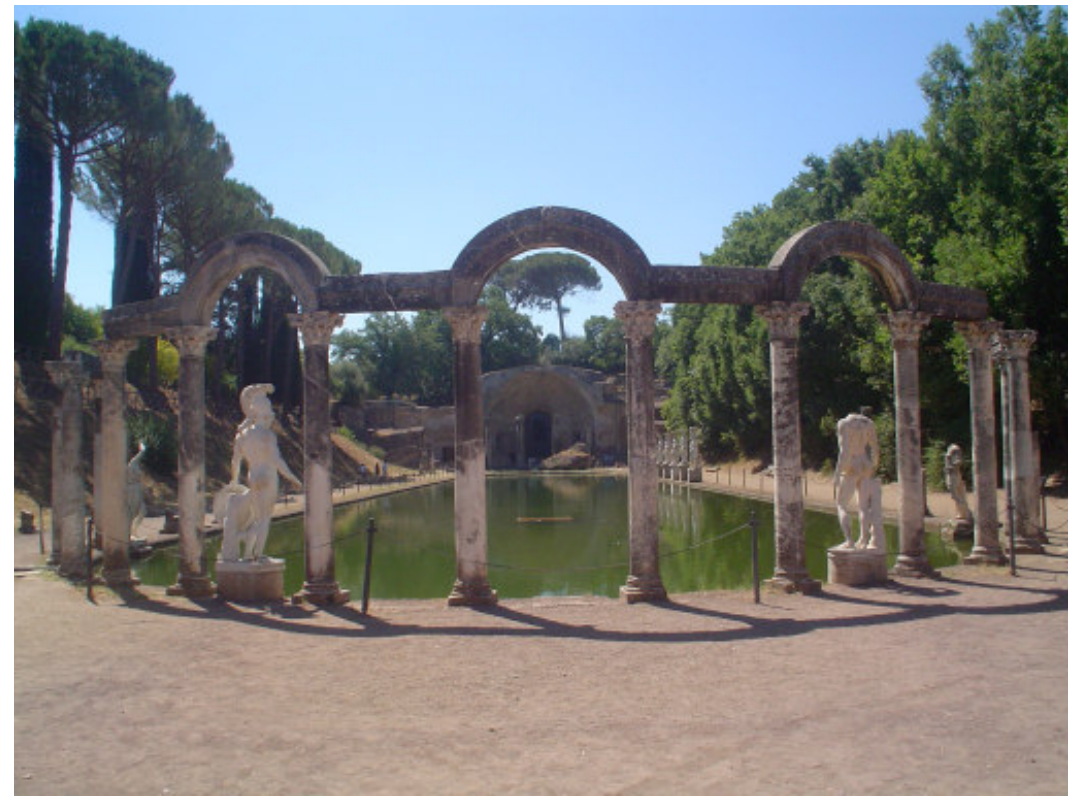

Fig 6. Canopus, na Vila Adriana.

No período subseqüente, dominado pela arquitetura medieval gótica, a exploração do ornamento torna-se mais assumida e evidente. A imponência arquitetônica das grandes catedrais depende diretamente da ornamentação presente em seus portais rebuscados, vitrais detalhados, gárgulas e elementos escultóricos pensados em conjunto com a edificação. Além disso, por estar em constante construção, crescendo conforme cresce a cidade medieval, a catedral gótica recebe permanentes adendos ornamentais.

O declínio do modelo feudal, com a ascensão da burguesia, o início da configuração da cidade moderna e o Renascimento Italiano, retomam formas arquitetônicas clássicas. Porém, esta mesma ascensão burguesa permitirá, de certa forma, o surgimento da arte moderna com a legitimação do trabalho do artista, e esta legitimação, associada à acumulação de capital burguesa, estará posteriormente relacionada ao styling e, portanto, ao ornamento. Não é surpresa que a cres- 


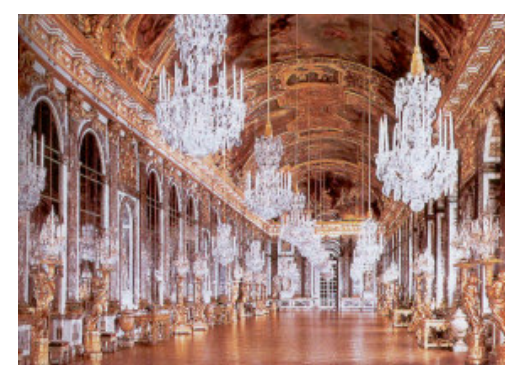

Fig 9. Sala dos espelhos em Versailles; opulência característica da monarquia francesa.

8. BURKE (1994)

9. BOTTON (2007) pp.34-46

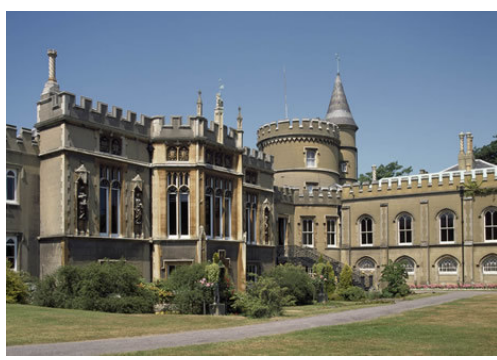

Fig 10. Strawberry Hill, residência construída em estilo gótico, por Horace Walpole.
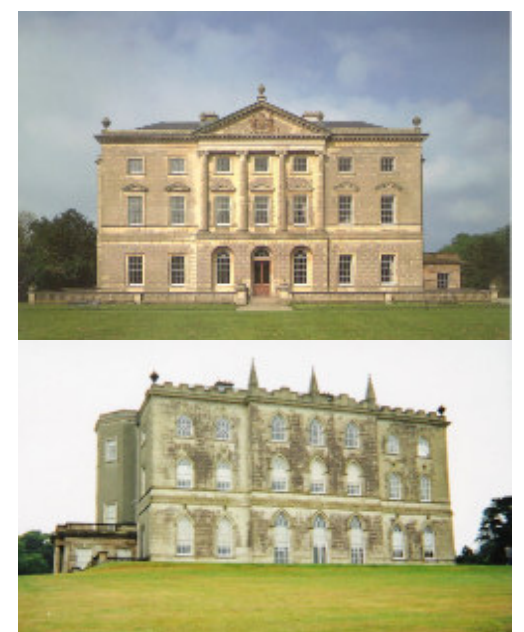

Figs 11 e 12. Fachadas frontal e posterior de Castle Ward, residência construída em dois estilos. cente opulência burguesa, inicialmente associada à presença de obras assinadas nos Palazzos, tenha encontrado barreira na composição arquitetônica dita mais clássica, característica do Renascimento, culminando com o Barroco e o Rococó, extremamente ornamentados. Na França, este é o estilo abraçado pela monarquia, para quem quanto maior fosse a ornamentação e riqueza, tanto do castelo quanto de seu interior, mobiliário e mesmo das celebrações oferecidas, maior o poder do rei. ${ }^{8}$

Durante o período em que prevaleceu o classicismo, pouco foi feito que quebrasse a ordem. Porém, Botton ${ }^{9}$ narra dois casos especiais. Em 1747, o filho do primeiro-ministro britânico, orgulhoso em ser diferente e com especial apreço pelo período medieval, encomendou para si a primeira casa gótica do mundo. O vocabulário eclesiástico medieval foi adaptado para compor o programa residencial e, como o morador, orgulhoso de seu feito, abria a casa para visitação, logo apareceram outras construções inspiradas no estilo gótico. Botton chega a afirmar que é possível que tenha sido este o princípio do ecletismo, em que passa a ser permitido evocar qualquer passado na arquitetura. O segundo caso narrado por Botton revela a que ponto chegou a liberdade estilística. Em meados do século XVIII, um casal de posses desejava construir uma casa, mas não chegava a um consenso quanto ao estilo a ser adotado - ela preferindo o gotico, ele o clássico. A solução encontrada pelo arquiteto foi dividir a casa, com a fachada frontal e parte dos cômodos seguindo o estilo clássico, e a fachada posterior com o restante dos cômodos em estilo gótico.

Seguindo a linha da fantasia, talvez o exemplo mais emblemático seja o castelo de Neuscbweinstein, erguido entre 1869 e 1886, para o Rei Ludovico da Baviera. A construção, inspirada no passado medieval, tem interiores que antecipam o temático, com elementos figurativos remetendo à ópera de Richard Wagner, incluindo, até mesmo, um cômodo que reproduz uma gruta. Aparentemente luxuoso, na verdade se trata de um grande cenário, em que as luminárias de ouro e pedras preciosas são, na realidade, pintadas e feitas com resina. Curiosamente, este precurssor do temático foi o modelo adotado por Walt Disney para o castelo na Disneyland - a cópia 


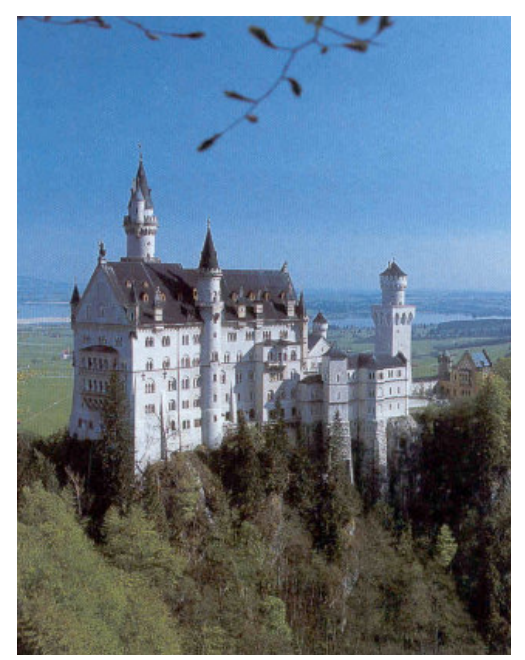

Fig 13. Castelo de Neuschweinstein; Füssen, Alemanha.

10. OECHSLIN e BUSCHOW da cópia.

Portanto, a ornamentação esteve sempre presente de alguma forma na arquitetura antiga e medieval. Embora possamos identificar, desde o século XV, manifestações que remetem à Arquitetura Temática, como os projetos para ornamentação de festas ${ }^{10}$ e exposições internacionais, por exemplo, é a partir da busca assumida pelo lucro comercial máximo que temas externos à esfera da arte e arquitetura passam a ser inseridos em projetos. Deve-se ressaltar que somente com o capitalismo surgiu a chamada indústria do entretenimento e, conseqüentemente, foi possível a Arquitetura Temática no sentido aqui estudado, porque aparece a possibilidade de transformar em lucro o tempo ocioso. Se, antes, apenas o tempo dedicado ao trabalho era considerado gerador de finanças, agora o tempo livre passa a ser ocupado por atividades comercializáveis. O uso de temas em ambientes comerciais constitui um instrumento através do qual pode-se potencializar o lucro obtido a partir destas atividades, incentivando turismo e lazer. Entretanto, se, por um lado, o temático assumido parece recente, associado aos grandes parques, especialmente aos complexos do grupo Disney, por outro, veremos que a ornamentação objetivando uma valorização da arquitetura precede em muito esta Arquitetura Temática.

Podemos considerar que coincide com o Art Nouveau a primeira aparição do ornamento como elemento compositivo na arquitetura pós-revolução industrial. Associada à Revolução Industrial está a, recém-surgida, necessidade de reduzir o tempo de consumo a fim de torná-lo compatível com o novo tempo de produção acelerado. Isto porque o crescimento da capacidade de produção alcançado após a revolução industrial demanda um aumento de consumo. Portanto, a partir do momento em que começa a surgir o excedente de produção, este comércio de bens necessários cresce em diversidade; indústria e comércio assumem a função de criar novas necessidades, das quais o consumidor não tinha consciência. Estando satisfeitas as carências práticas, são criadas novas exigências que o consumidor incorpora, de modo que a indústria de bens de consumo propicia um aumento considerável da quantidade de itens considerados necessidade básica. 
11. LOOS, Adolf, Ornament and Crime. In. FOSTER (2003) p.13

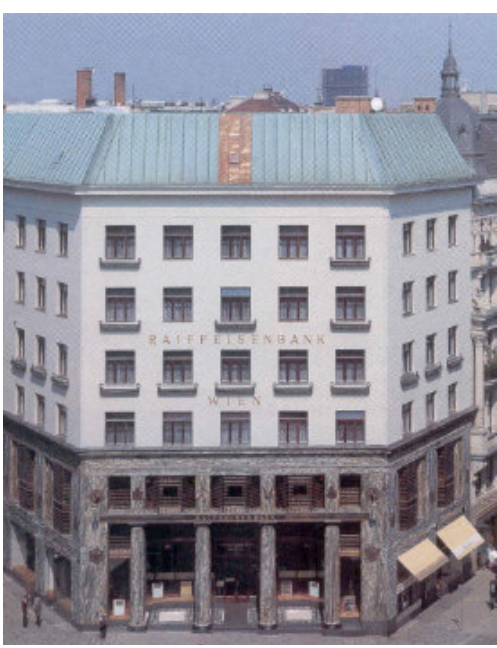

Fig 14. Edifício de uso misto, projeto de Adolf Loos; Viena, Áustria.

12. GORMAN (2004) pp.74-75

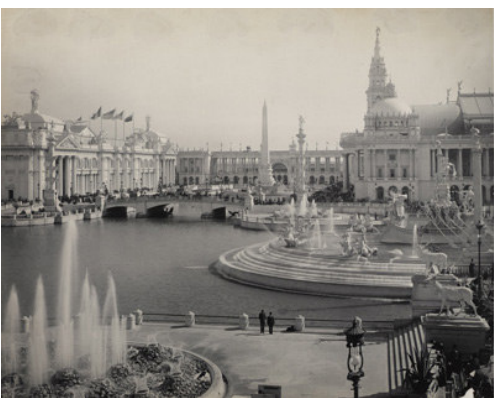

Fig 15. World's Columbian Exposition; Chicago, Estados Unidos.

13. FRAMPTON (2003) pp.103

109.
Não por acaso, a crítica a respeito desta exploração do ornamento pelo Art Nouveau tem sido produtiva desde então. Neste trabalho, serão analisados textos como "Ornament and crime"(1908), de Adolf Loos, em que afirma que a "a evolução da cultura é sinônimo da remoção do ornamento de objetos utilitários", associando "ornamento e crime" ticas que respondem ao histórico manifesto de Loos, como "Design and Crime"(2003), de Hal Foster.

O arquiteto austríaco Adolf Loos (1870-1933) é provavelmente conhecido hoje tanto por seu ensaio, "Ornament and Crime", como pelas estruturas modernistas inovadoras que construiu depois de 1910, incluindo algumas das primeiras residências privadas feitas em concreto reforçado. No ensaio, o arquiteto defende que o grau de civilização de uma sociedade pode ser medido pelo grau em que baniu o ornamento. ${ }^{12}$ Loos viajou pelos Estados Unidos de 1893 a 1896, tempo em que visitou a World's Columbian Exposition de 1893, em Chicago. Esta Feira Mundial apresentou um novo modelo de parque, com uma rua principal em torno da qual giravam as principais atrações. Essa via, chamada de "midway", com uma grande variedade de brinquedos, era um sucesso enorme e ditou a configuração espacial de parques de diversões durante os sessenta anos seguintes. Atualmente, pode-se observar que a proliferação de ruas temáticas ou ruas 24 horas ainda segue o mesmo conceito. Entretanto, Loos parece ter sido mais influenciado pela visita aos novos "arranha-céus" em estrutura de aço que estavam sendo construídos em cidades como Chicago, Nova York, e Saint Louis. Ao retornar, iniciou sua carreira como arquiteto, além de passar a escrever artigos para revistas especializadas.

Segundo Kenneth Frampton ${ }^{13}$, Loos condena o ornamento não apenas por promover trabalho desnecessário e perda de materiais, mas também por estabelecer uma espécie de escravidão ao artesanato, que só se justificaria para aqueles sem acesso à cultura mais elevada. Este tipo de declaração, ética e esteticamente polêmica, teria isolado Loos de outros teóricos da época, inclusive de seus sucessores. Frampton continua, afirmando que, embora polêmico, Loos foi pioneiro em perceber a nova realidade moderna quando vê que o arquiteto 
14. RYBCZYNSKI (1999) pp.181-

urbano nasce desvinculado do passado rural, não podendo buscar as raízes clássicas aristocráticas como compensação por esta perda de vínculo. A solução apresentada por Loos seria dissociar a arquitetura produzida por esta burguesia, definitivamente não aristocrática, da arte, considerando-a como edificação. Propõe, então, o uso de peças de vestuário e mobiliário sem ostentação e ornamento, antecipando, em parte, o "objeto-tipo" de Le Corbusier. Na prática construtiva, a ideologia se reflete em projetos residenciais abstratos, usando a linguagem geométrica limpa do cubo branco e, mais tarde, evoluindo para planos escalonados, que influenciariam definitivamente o movimento moderno francês.

Assim, a condenação ao uso do ornamento ganha força e nos influencia até os dias atuais, principalmente por sua relevância durante o período em que prevaleceu a estética modernista. A idéia de que "a forma segue a função", afirmação feita pelo arquiteto Louis Sullivan, foi, segundo Witold Rybczynski, "citada com tanta freqüência, que é fácil esquecermos que era um slogan e não uma regra". ${ }^{14}$

Esta estética funcionalista do movimento moderno é representada, principalmente, por Le Corbusier e sua propos15. FRAMPTON (2003) p.182. ta de construir a "Máquina de morar". Segundo Frampton", esta proposta é explicitamente exposta pela primeira vez em um artigo de Le Corbusier publicado pela revista "L'Esprit Nouveau", intitulado "Le Purisme", que abrangia todas as áreas de expressão e questionava as distorções cubistas, propondo um refinamento de estilos. Entretanto, para Frampton, o período de maior expressão de Le Corbusier coincide com a uma arquitetura". publicação do clássico "Vers une architecture"(1923) ${ }^{16}$, também pré-publicado em parte na revista "L'Esprit Nouveau". Neste texto, Le Corbusier salienta a necessidade primordial de se atender às demandas funcionais, bem como a importância de, para isso, fazer uso de formas abstratas que despertem reflexão intelectual. Esta linguagem, influenciada pela perfeição que Corbusier enxergava na técnica e precisão da produção industrial, é chamada "Esthétique et Architecture de l'Engenieur". Frampton cita um trecho do livro em que ficam evidentes o racionalismo e a idéia da produção em série aplicados à moradia, propostos por Corbusier: 
17. LE CORBUSIER. Vers une architecture. In. FRAMPTON (2003)

p.183.

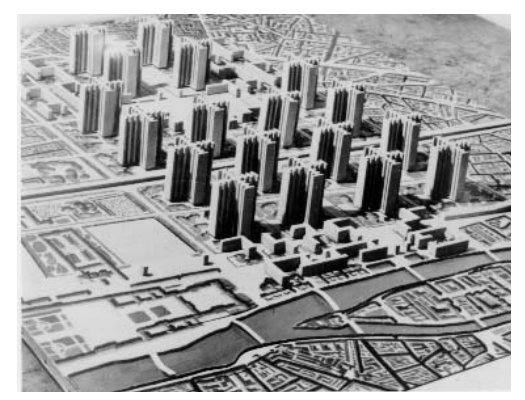

Fig 16. Plan Voisin.

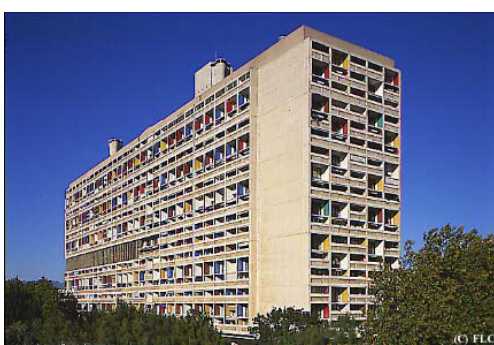

Fig 17. Ville Radieuse.

\begin{abstract}
"Se eliminarmos de nossos corações e mentes todos os conceitos mortos a propósito das casas e examinarmos a questão a partir de um ponto de vista crítico e objetivo, chegaremos à “máquina de morar”, a casa de produção em série, saudável (também moralmente) e bela como são as ferramentas e os instrumentos de trabalho que acompanham nossa existência." ${ }^{17}$
\end{abstract}

Seguindo sua preocupação com o projeto em escala urbana, Le Corbusier, após ter desenvolvido uma série de residências em que prevalecia a proposta da máquina de morar, parte para propostas de habitação coletiva, em que as unidades individuais, chamadas células habitacionais, são sobrepostas em construções verticalizadas. O famoso Plan Voisin, para Paris, em que era proposta a derrubada de uma grande área de construções na zona central e histórica da cidade, abrindo espaço para a construção de grandes torres cruciformes, trazia a proposta da máquina de morar para o âmbito urbano, a partir do momento em que colocava uma série de atividades urbanas dentro dos edifícios e explorava o automóvel para o funcionamento eficiente da cidade. O projeto, essencialmente utópico, não foi efetivado, mas teve repercussão direta na concepção da Ville Radieuse, em que Le Corbusier finalmente propõe e constrói a cidade vertical, com edifícios multifuncionais.

Rybczynski mostra que as inovações tecnológicas haviam tido até o movimento modernista pouca ou nenhuma influência na conformação estética dos interiores residenciais, pois a tecnologia havia sido incorporada no uso de eletricidade e, mais tarde, de eletrodomésticos, mas inserida dentro de uma estética ornamentada, ditada mais pela moda e gosto popular que pela tecnologia em si. Este aparente equilíbrio entre tradição e inovação seria quebrado com a chegada da estética moderna, marcada pela Exposition Intrenationale des Arts Décoratifs et Industriels Modernes, realizada em 1925, em Paris, com a proposta de apresentar as últimas idéias na decoração de interiores. Por toda a exposição predominaram ambientes decorados com riqueza e formas rebuscadas, seguindo o que seria, em função da própria exposição, denominado estilo Art Déco. A linguagem Déco se propunha moderna e urbana, sem 
qualquer referência a estilos históricos, e Rybczynski afirma que os organizadores da exposição informaram explicitamente que não deveria haver, nos interiores apresentados, menção alguma a referências históricas. Entretanto, ainda que sob uma estética vista como moderna, e demonstrando apreço pela tecnologia, estavam presentes nos interiores Déco os elementos do passado - candelabros, frisos, etc - bem como permanecia

201. intacta a noção de conforto até então predominante. ${ }^{18}$

Um pavilhão pouco visto e comentado seria, no entanto, o mais marcante desta exposição. A revista L'Esprit Nonvean apresentou um projeto de Le Corbusier, então seu editor, em parceria com seu primo Pierre. Tratava-se de uma construção cúbica totalmente branca, com exceção das letras EN aplicadas na fachada. Consta que a maior parte do público pensou tratar-se de obra ainda não concluída e a crítica da época não mencionou o pavilhão, desconsiderando-o.

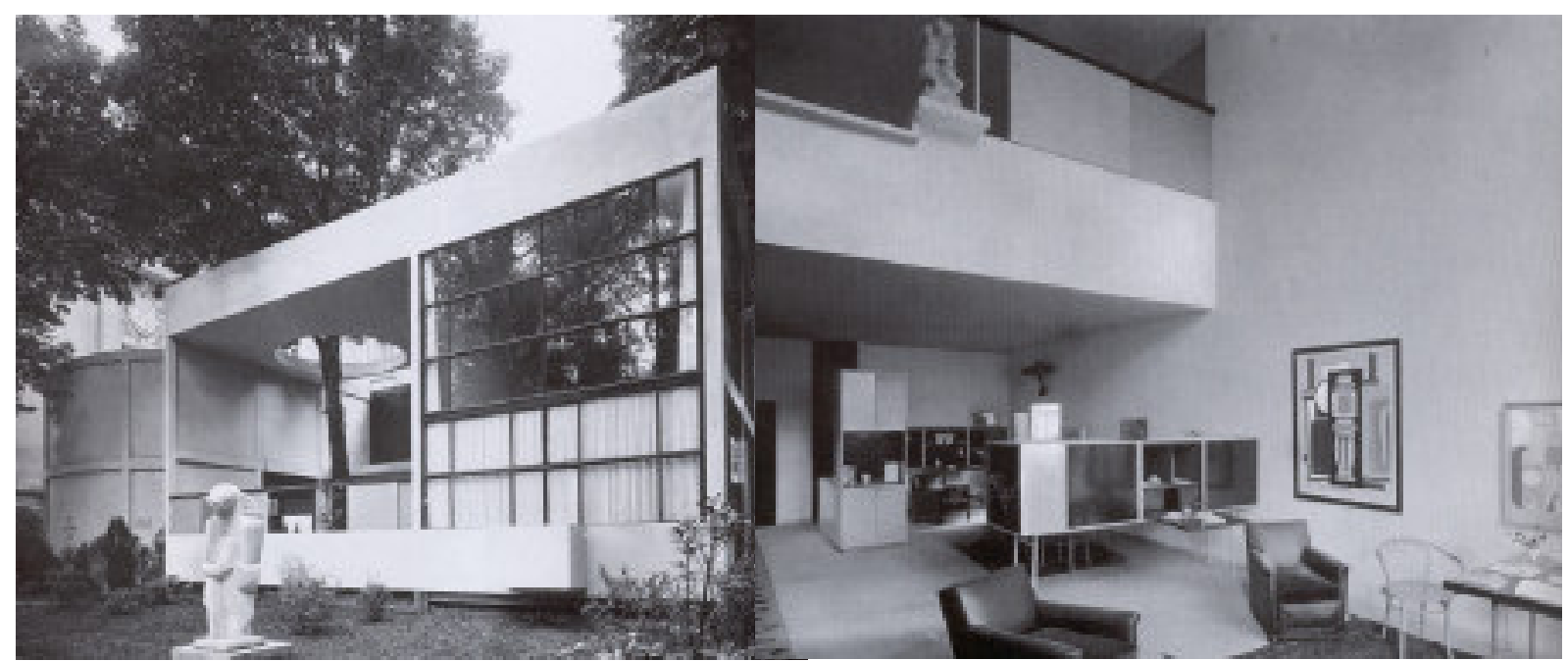

Figs 18 e 19. Pavilhão L'Esprit Nouveau.

O interior apresentava-se tão vazio quanto o exterior, sem ornamentação, cortinas ou papel de parede, com as paredes totalmente brancas, exceto uma, em marrom, em contraste com um teto azul e armários em amarelo. As janelas eram modelos normalmente utilizados na indústria, assim como o mobiliário, bastante comum. Ao contrário do que poderia pensar o visitante, esta aparente simplicidade não foi conseqüência de limitações de orçamento, embora elas existissem, e sim da proposta de recusar todo e qualquer ornamento ou reconstituição histórica. Le Corbusier apresentava sua "máquina de morar" propondo uma residência que contasse com 
19. Idem pp.200-201

20. FRAMPTON (2003) p.188.

(1)
blicou "Le 5 points d'une arcbitecture nouvelle", em que determina os hoje clássicos cinco pontos fundamentais a serem seguidos para a expressão modernista: uso de pilotis elevando o primeiro pavimento e liberando a área do solo, planta livre em decorrência da separação entre estrutura e paredes, fachada livre, vãos horizontais e uso de terraço-jardim como forma 21. Idem p.188. de recriar o espaço ocupado no solo pela edificação. ${ }^{21}$ Este modelo rígido não permitia, evidentemente, a inclusão de ornamentos e referências não arquitetônicas.

Le Corbusier e o movimento francês marcaram, sem dúvida, a estética moderna, mas outras vertentes certamente contribuíram para a consolidação desta rejeição ao ornamento. Giulio Carlo Argan identifica, dentro da chamada ótica moderna, seis orientações distintas relacionadas a localizações, 22. ARGAN (2002) p.264 situr situações sócio-culturais e influências diversas. ${ }^{22}$ Entretanto, afirma que as diversas correntes modernas aproximam-se por princípios comuns - priorizam o planejamento urbano, propõem o uso mínimo do solo, adequam a forma arquitetônica a um sistema causal, aliam-se à produção industrial e consideram a arquitetura moderna e a indústria condicionantes do progresso. Em suma, o funcionalismo e, conseqüentemente, a 
desqualificação do ornamento, permeiam a estética moderna, qualquer que seja sua vertente.

A discussão sobre o ornamento na arquitetura e design permanece, inclusive, em críticas bastante recentes. Remetendo ao texto de Adolf Loos, "Ornament and Crime", Hal Foster publicou, em 2003, "Design and Crime (and other diatribes)", cujo capítulo II, "Design and Crime", parece realmente uma resposta a Loos, atualizando suas idéias, para aplicá-las em relação ao momento presente.

Foster identifica, na virada do último século, uma retomada da estética Art Nouveau em que o designer se esforça para, através de uma decoração rica e elaborada, dotar todos os objetos de subjetividade. Este modelo, na época conhecido como Gesamtkunstwerk, ou 'trabalho total', era aplicado nas artes e ofícios, de modo que tudo, da arquitetura aos cinzeiros, recebesse esta ornamentação. Para Foster, o retorno das práticas associadas ao Art Nouveau, considerado vulgar e fora de moda, desde o final dos anos 20 , indica que passamos por um momento em que objetos são identificados como "mini-sujeitos" e há cada vez menos distinção entre os saberes. Questiona, então, se não seria o caso de retomarmos a distinção entre práticas, preconizada por Loos, desta vez, evidentemente, desprovida do décor puritano e bagagem ideológica que permearam "Ornament and Crime" e toda sua obra.

Foster cita um esquete escrito por Loos em que um homem contrata um designer para colocar "arte em toda e qualquer coisa" - paredes, mobiliário, objetos utilitários, etc. Terminado o projeto, o homem sente-se profundamente infeliz, pois, para Loos, ao acrescentar qualidades a tudo, ele

23. Foster utiliza com freqüência o termo "designer Art Nouveau". A denominação é certamente controversa, já que na época não era legitimado o profissional e nem mesmo estava estabelecido o conceito de Design. Aqui foi feita a opção por manter as palavras de Foster somente quando estiver fazendo referência a seus escritos.

24. FOSTER (2003) pp.13-26 perde a distinção, tornando-se, paradoxalmente, um homem sem qualidades. Os designers Art Nouveau ${ }^{23}$ teriam, portanto, pretendido infundir arte em objetos utilitários, o inverso do que fariam, mais tarde, os modernistas, tentando elevar o objeto utilitário à arte.

Foster retoma este debate, justificando sua atualidade no fato de que hoje é ainda mais intensa a fusão entre a estética e o utilitário, e tudo pode ser visto como design. Após a prevalência do "artista-engenheiro" 24 modernista, ressurgiria a figura do designer, porém, ao contrário do designer Art Nou- 
25. BAUDRILLARD, Jean. For a Critique of the political economy of the Sign. In. FOSTER (2003) p.20 veau, para Foster resistente à indústria, o designer contemporâneo se alinharia com a tecnologia, fazendo uso e dependendo dela. Além disso, a penetração do design na sociedade é agora bem mais abrangente, atingindo empresas, grupos sociais e setores de atuação diversos. Cabe aqui ressaltar que, embora os seguidores da estética Art Nouveau realmente tenham colocado resistência à industrialização, valorizando referências à natureza e ao trabalho artesanal, por outro lado adotaram a produção industrial, bem como os novos materiais difundidos com o desenvolvimento da indústria.

O próprio Foster prevê o contra-argumento de que estética e utilidade já foram unidos dentro da lógica comercial, pelo menos desde os anos 20, com a Bauhaus. Segundo Baudrillard, embora não fosse a intenção final dos professores da Bauhaus, a escola promoveu uma transição da "economia política do produto" para a "economia política do signo". ${ }^{25}$ Assim, a antiga proposta de reconectar o estético ao utilitário ou, como diz Foster, "reconectar Arte e Vida", levantada pelo Art Nouvean e apoiada, segundo ideologias diversas, pela Bauhaus e outros movimentos ao longo do tempo, seria finalmente alcançada através do design, mas, desta vez, seguindo a lógica da indústria cultural. Foster conclui que, embora o modelo do design total não seja novo, parece ter sido só agora plenamente alcançado.

A explicação reside no fato de que, no início da produção massificada pós-revolução industrial, reinava a uniformidade. Logo passou a ser necessário atrair o consumidor criando atrativos diferenciais, em um processo que tornou a embalagem o chamariz para o produto. Estava traçado o caminho para o design moderno, em que o produto é subjetivado. Com a flexibilização da produção, é possível, hoje, produzir em massa e, simultaneamente, atender a públicos mais específicos. O produto torna-se definitivamente personificado, promovendo a expansão do design.

Foster identifica duas outras motivações para a expansão do design, a brand-equity - valorização da marca - seja qual for o produto, e o crescimento da indústria da mídia. No primeiro caso, percebe-se que, cada vez mais, as marcas concentram esforços no branding, valorizando sua identidade mais 
26. MAU, Bruce. Life Style In.
FOSTER (2003) p.22.
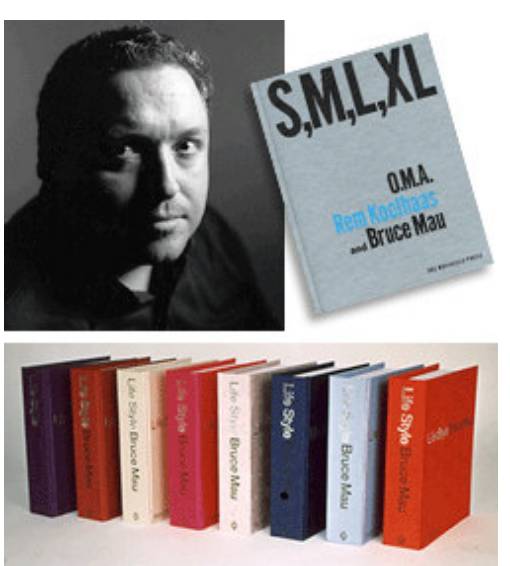

Fig 20. Bruce Mau, S,M,L,XL e Life Style.

27. Idem que seu produto, pois é justamente esta identidade que traz valor ao produto, seja este um objeto, serviço ou mesmo uma pessoa, um político, por exemplo. Já o crescimento da mídia, para Foster, se traduz em uma nova relação com o produto, que pode ser pensado não como um objeto produzido, mas como dados a serem manipulados. Este novo produto depende, portanto, ainda mais do design, para que estes dados sejam projetados, pensados e reprojetados.

Para ilustrar a situação atual do design, Foster recorre ao livro "Life Style", de Bruce Mau. ${ }^{26} \mathrm{O}$ extenso trabalho, repleto de experimentação com cores e fontes, parece ser mais valorizado como uma experiência de design que intelectual e constitui, na prática, um compêndio de projetos e histórico de seu estúdio, um manifesto em favor de si próprio. O design de Bruce Mau, bastante requisitado desde então, passou a ser identificado com a produção da imagem, um design voltado para a valorização da marca. Mau chega a afirmar que "Neste ambiente, a única maneira de cons-
truir valor real é acrescentar valor: embru-
lhar o produto com inteligência e cultura. O
produto aparente, o objeto ligado à transação,
não é, de forma alguma, o produto verdadei-
ro. O produto real converteu-se em cultura e
inteligência." 27

Foster cita, ainda, o que seria o equivalente a "Life Style" no campo da arquitetura, "S, M, L, XL", de Rem Koolhaas com projeto gráfico de Bruce Mau, cujo título nos lembra, além das diversas escalas de trabalho do autor, a necessidade de possuir linhas de produtos adequadas a todos os tipos de consumidores.

Foster vai além, ressaltando que, se existe claramente a confluência entre signo e produto, o mesmo tem acontecido entre espaço e produto, combinados, através do design, em shoppings reais e virtuais. Exemplifica citando novamente Mau que, sobre um projeto de criação de identidade para uma rede de livrarias, afirma que se trata de um "ambiente de venda... em que identidade da marca, sistema de sinalização, 28. Ibidem interior e arquitetura seriam totalmente integrados." 28 Relembrando a figura de linguagem favorita dos designers contemporâneos, como Mau, Foster diz que em relação à sociedade, 
30. Ver capítulo 5.1

29. Ibidem

eles, mais que críticos do espetáculo, são surfistas do espetáculo, como disse Mau com "o status do artista [e] a folha de pagamento do homem de negócios" 29.

Foster conclui que este modelo atual do design total, voltado para a imagem, é a apoteose do sujeito e, paradoxalmente, sua simultânea extinção. Ao mesmo tempo em que promove a subjetivação de qualquer objeto ou elemento da vida cotidiana, em contrapartida, o design total envolve o sujeito em uma capa imagética tão rígida que pode desprovê-lo de subjetividade. A esta afirmação poderemos associar a crítica acerca da possível desconstrução de identidades locais, quando adotado um referencial temático no espaço urbano. ${ }^{30}$

Vimos, portanto, que o debate sobre a presença, pertinência e relevância do ornamento na arquitetura antecede qualquer discussão sobre a pós-modernidade. Ao longo da história, observamos períodos de prevalência estética alternando momentos de valorização e condenação ao ornamento, bem como sofre alterações o papel a ele atribuído.

1.2 Se, na maior parte da Europa, predominava a estética

Styling e Kitsch: respostas precoces ao modernismo modernista, nos Estados Unidos aparecia uma alternativa estética que retomava a valorização do ornamento, sob a ótica do styling, termo cunhado após a crise de 1929, que carrega ainda hoje uma carga negativa. No momento de crise, a indústria se viu obrigada a adotar novas estratégias para atrair o consumidor, especialmente a de tornar propositalmente o objeto obsoleto a fim de incentivar a compra de um substituto. Esta obsolescência era alcançada com um redesenho periódico do produto, de acordo com uma estética diferenciada, e sem ter necessariamente qualquer motivação funcional. Além de tornar o produto mais atrativo, incentivando sua substituição, o styling funcionou como instrumento para atrair o consumidor para determinado produto em detrimento do concorrente. $\mathrm{O}$ conceito foi definido por Gillo Dorfles:

\footnotetext{
"De fato, o verdadeiro significado da palavra pode ser considerado o de uma adequada e cuidada cosmética do produto, de maneira a dar um novo fascínio e uma nova elegância ao objeto, prescindindo de qualquer verdadeira
} 

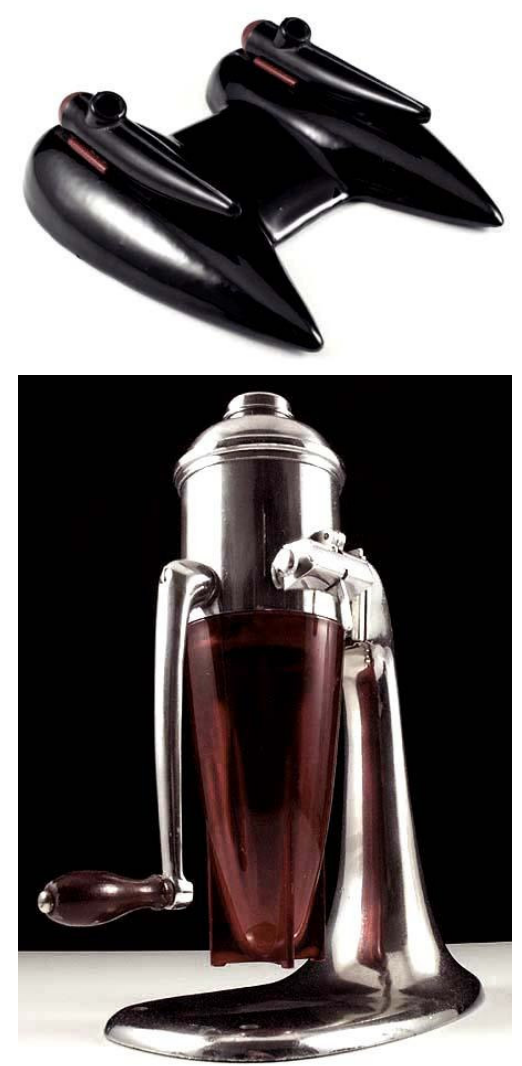

Figs 21 e 22. Suporte para canetas e moedor de gelo com formas aerodinâmicas; década de 30 .
Embora pareça negar a prática, Dorfles se propõe a apresentar seus pontos positivos e negativos. Identifica, então, uma valiosa relação entre as transformações estilísticas promovidas e as transformações simbólicas da sociedade em que se inserem. Para acentuar esta relação, cita o exemplo da tomada do mercado norte-americano por formas aerodinâmicas em objetos cuja função era essencialmente estática. Produtos que não apresentavam qualquer requisição funcional para possuir modelagem aerodinâmica recebiam esta formatação, em função do significado de atualidade, evolução e movimento associado à forma. $\mathrm{O}$ valor simbólico da forma se colocava independentemente dos aspectos funcionais do objeto.

Evidentemente, esta prática foi negada pelos puritanos modernistas, pregadores da apologia ao funcionamento, assim como da forma ideal como conseqüência de função e estrutura bem resolvidos. Neste sentido, não há como negar a relevância do styling no contexto da evolução do uso e crítica do ornamento na arquitetura, pois, ainda que não no campo teórico, o que faria mais tarde Robert Venturi, na prática o modelo quebra a rigidez modernista e levanta outra possibilidade, anos antes de os críticos falarem em pós-modernismo.

O próprio Dorfles aponta elementos positivos no styling, assumindo não possuir visão tão negativa sobre o modelo quanto seus precedentes; afinal, o desejo por diferenciação parece inerente ao ser humano. Uma das principais críticas ao styling residia em sua relação intrínseca com o capitalismo, tratando o modelo como estratégia de promoção do consumo e construção de necessidades, exclusiva dos países então capitalistas e, predominantemente, americana. De fato, o modelo foi inaugurado nos Estados Unidos, mas Dorfles mostra que logo chega à Europa quando esta entra em crise econômica. Além disso, identifica sua presença na ex-União Soviética comunista que, mesmo sem a concorrência típica do capitalismo, ainda precisava convencer o consumidor a abandonar certos produtos em bom estado de funcionamento para substituí-los por mais novos, de acordo com a necessidade da indústria estatal.

A conotação pejorativa dada ao styling está, ainda hoje, bastante relacionada à presença de elementos ornamentais 
desnecessários na arquitetura e design, situação, por sua vez, associada ao kitsch. Abraham Moles mostra que a percepção pejorativa do kitsch, sempre associado a uma quebra de autenticidade, é intrínseca à sua própria definição, uma vez que a palavra deriva do alemão verkitschen - trapacear. Moles define, inicialmente, o kitsch como

“(...) um conceito universal, familiar, importante, que corresponde, em primeiro lugar, a uma época da gênese estética, a um estilo marcado pela ausência de estilo, a uma função de conforto acrescentada às funções tradicionais, ao supérfluo do progresso." 32

Entretanto, afirma que a compreensão do kitsch está primordialmente associada a uma conotação intuitiva, melhor entendida por exemplos que por definições.

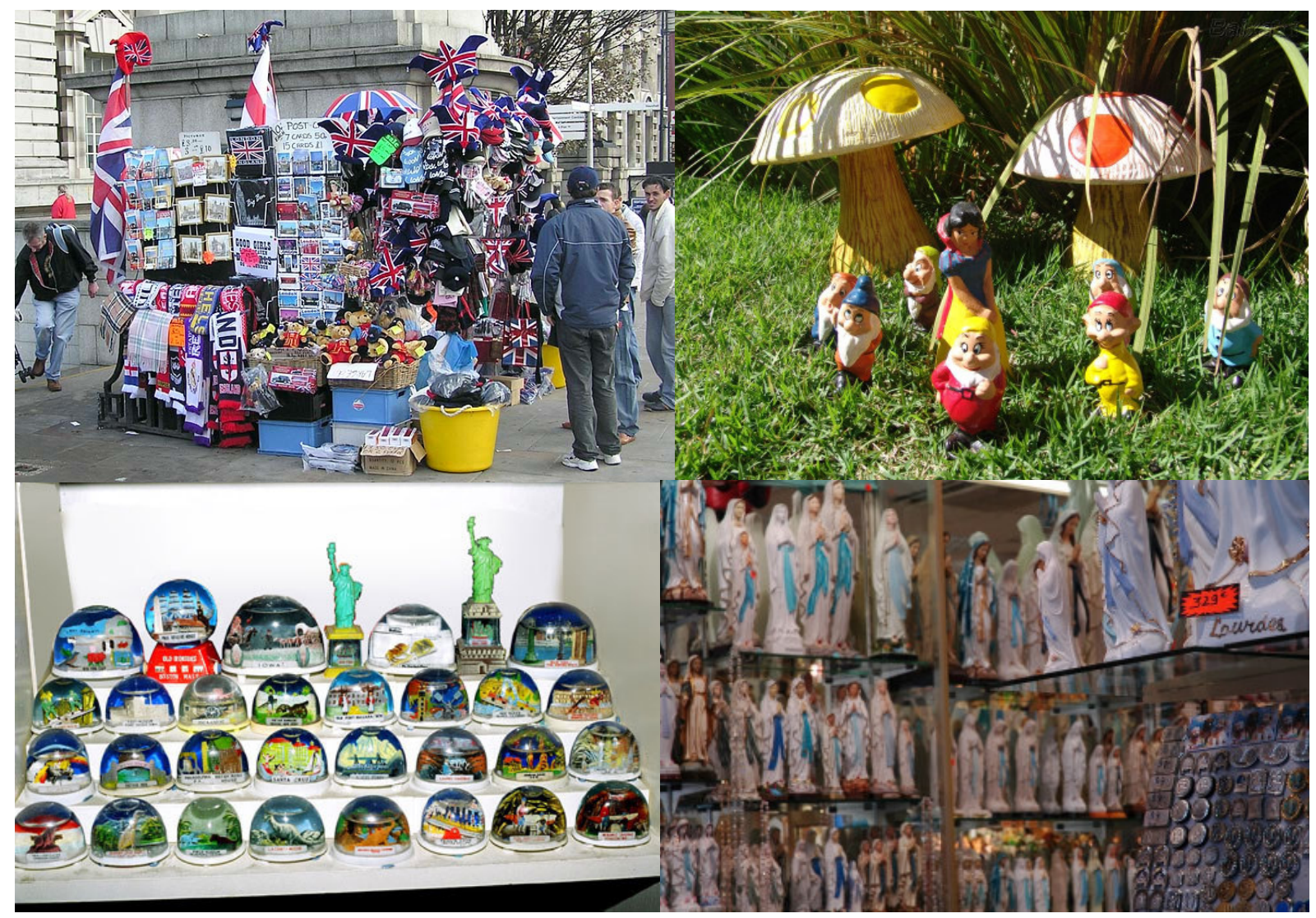

Figs 23, 24, 25 e 26. O Kitsch: vendedor de souvenis em Londres, anões de jardim, coleção de domos de neve e kitsch religioso em Lourdes; França.

Assim, Moles trata o kitsch como fenômeno social, relacionando sua aparição a uma situação social de ascensão burguesa que permite o acesso à opulência; quando é quebrada a dicotomia entre feio e belo na arte, o intervalo é ocupado pelo kitsch. Com a Revolução Industrial, separam-se definitivamente os atos de criação - invenção, inserção de formas inéditas 
- e produção - replicação e cópia de formas existentes. O homem que opera a máquina industrial enfrenta a alienação do trabalho. Por outro lado, se já não se ocupa da criação, o trabalhador ganha um tempo livre dedicado ao ócio, e o consumo ocupa este espaço.

A estética kitsch baseia-se nesta sociedade de consumo em que o objeto adquire características supra-utilitárias, tornando-se sempre provisório. Se antes o objeto caracterizava-se por sua função pragmática, Moles afirma que passa gradativamente a adquirir valor conotativo, definindo status e classe social. Justamente por acumular as características de gerador de status e opositor da simplicidade a uma acessibilidade ao homem comum, à vida cotidiana, o kitsch ganha espaço. A presença do kitsch na sociedade contemporânea está, portanto, relacionada à ascensão da classe média, tanto quanto foi associada à ascensão burguesa no passado.

$\mathrm{O}$ autor mostra que recontextualizando objetos podemos dotá-los de características kitsch. Mais que um adjetivo, para Moles o kitsch é uma forma de relação estética com o ambiente. Existiria, portanto, uma maneira kitsch de olhar os objetos. Este olhar parece relacionado ao que Marx chamou "fetichismo da mercadoria", assim definido:

"Há uma relação física entre coisas físicas.

Mas a forma mercadoria e a relação de valor entre os produtos do trabalho, a qual caracteriza essa forma, nada têm a ver com a natureza física desses produtos nem com as relações materiais dela decorrentes. Uma relação socia1 definida, estabelecida entre os homens, assume a forma fantasmagórica de uma relação entre coisas. Para encontrar um símile, temos de recorrer à região nebulosa da crença. Aí, os produtos do cérebro humano parecem dotados de vida própria, figuras autônomas que mantêm relações entre si e com os seres humanos. É o que ocorre com os produtos da mão humana, no mundo das mercadorias. Chamo a isso de fetichismo, que está sempre grudado aos produtos do trabalho, quando são gerados como mercadorias. É inseparável da produção de mercadorias." 33

Mesmo adotando uma definição através de exemplos e 
analogias, Moles procura, ainda, elencar características tipológicas do kitsch. Inicialmente mostra que, ainda que o tamanho do objeto não tenha qualquer relação com uma possível aproximação em direção à estética kitsch, encontra-se uma farta oferta de objetos kitsch que fazem uso de distorções de escala, especialmente no caso das réplicas em miniatura. Busca, então, definir parâmetros tipológicos para objetos kitsch e para conjuntos que apresentam características kitsch, ainda que individualmente não o sejam.

Dentre as principais características comuns apresentadas, Moles relaciona a predileção por curvas complexas, superfícies bastante ornamentadas, uso de cores, com a combinação de várias gamas e a substituição de materiais. Para os agrupamentos kitsch, as possibilidades identificadas foram o acúmulo de objetos em um volume pequeno para recebê-los, a junção de objetos não correlatos, a aproximação de elementos sem justificativa funcional e a "sedimentação", que representa o acúmulo lento de objetos sem preocupação com o conjunto.

Enfim, o kitsch parece estar relacionado à gratuidade, objetos ao alcance do homem sem função prática, por exemplo os souvenir de viagem e artigos religiosos. No caso dos exemplos citados, há uma proposta kitsch assumida, mas são igualmente encontrados gadgets, pequenos objetos ou acessórios engenhosos, cujo desenho não apresenta intencionalidade 34. MOLES (2001) pp.43-68. kitsch. ${ }^{34}$

Sabemos que o temático auto-legitimado surge nos Estado Unidos, onde, no design, o pós-modernismo precede de certa forma a filosofia européia, afinal o styling tem início em 1930. Podemos, então, questionar se não seria o temático um contraponto persistente ao modernismo. O pop, o kitsch, e, porque não, o temático, ainda que coincidam temporalmente com o período moderno e não tenham como objetivo direto atacar a estética moderna (o temático chega a se apropriar desta estética nos primeiros parques da Disney), agiram como reação à impavidez modernista e poderiam, portanto, estar na raiz do pós-modernismo e, conseqüentemente, da arquitetura contemporânea. 


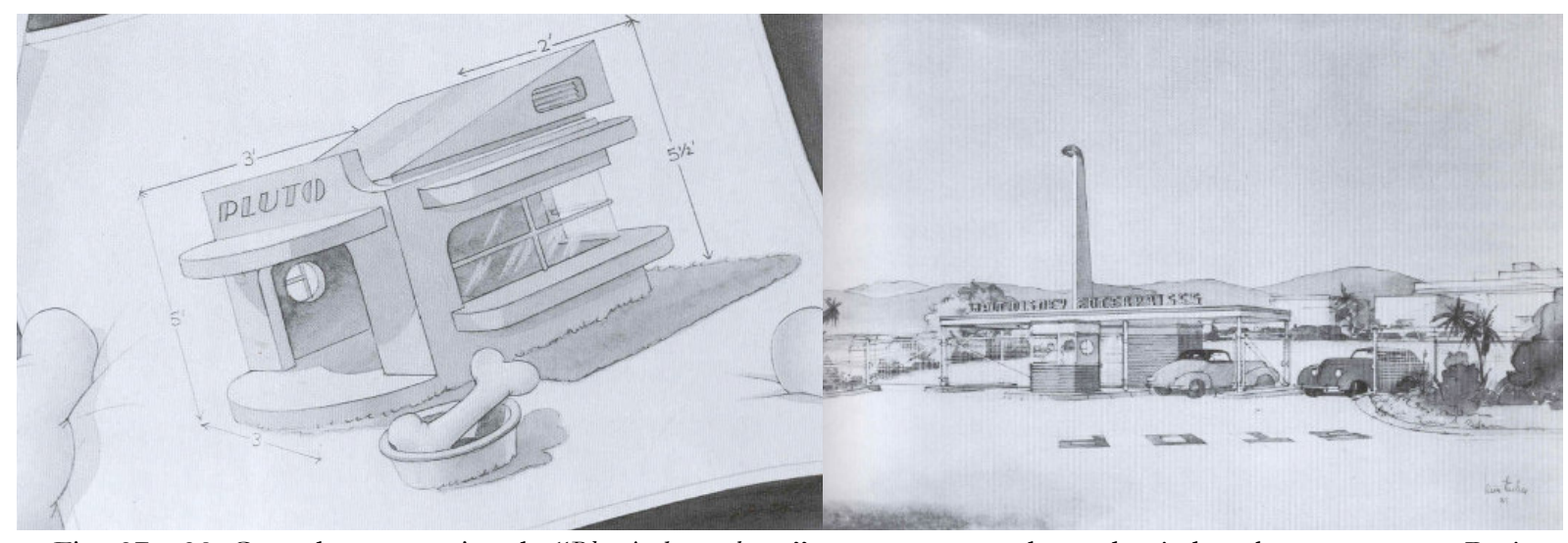

Figs 27 e 28. Cena do curta animado "Pluto's dream house", com a casa moderna desejada pela personagem. Projeto não executado de Kem Weber para a entrada dos estúdios Disney, seguindo a linguagem moderna.

1.3 Vimos que, enquanto a Europa seguia principalmente Venturi e o simbolismo a escola modernista, rejeitando qualquer espécie de ornamenna arquitetura to, nos Estados Unidos, especialmente no campo do design, já se quebrava a estética do "menos é mais" explorando o styling e o kitsch. Porém, segundo Kate Nesbitt, coube a Robert Venturi, com a publicação de "Complexidade e Contradição em Arquitetura", pelo MoMA, a possibilidade de inaugurar "a crítica norte-americana à hegemonia da corporação modernis35. NESBITT (2006) p.91. ta" ${ }^{35}$. Nesbitt afirma, ainda, que dentre aqueles que atribuíram tal qualidade ao livro está o historiador Vicent Scully, autor da introdução ao trabalho de Venturi. Scully traça, nesta introdução, um paralelo com o clássico "Vers une Architecture" (1923) de Le Corbusier, chegando a afirmar que o texto de Venturi seria o "mais importante livro escrito sobre criação e produção de arquitetura" desde então. Scully avalia que, assim como Le Corbusier questionava "os seguidores incondicionais das Belas Artes", Venturi questiona os seguidores de Le Corbusier e da estética modernista. Já em nota à segunda edição, de 1977, Scully afirma se orgulhar do paralelo traçado. Segundo ele, a comparação, antes tida com ousada e atrevida, ficou comprovada com o passar do tempo.

Não surpreende, portanto, que, anos mais tarde, Scully tenha contribuído com o prefácio do livro "Building a Dream: the art of Disney architecture", sobre a arquitetura produzida por nomes reconhecidos para diversos edifícios dos complexos de entretenimento Disney ao redor do mundo. Neste prefácio, intitulado "Disney: theme and reality", Scully, ao tratar sobre 
36. DUNLOP (1996) pp.7-11

37. VENTURI (1995) a questão do temático na arquitetura dos parques, levanta a possibilidade de que também a arquitetura moderna seja temática, na medida em que assume como tema a própria modernidade. ${ }^{36}$ Scully, inclusive, cita Venturi como o primeiro a nos lembrar que o reducionismo modernista rejeitava os recursos simbólicos e narrativos mais complexos e ricos que haviam permeado a arquitetura até o início do século.

Este primeiro livro de Venturi ${ }^{37}$ parece ter, realmente, sido o pioneiro em questionar abertamente o modelo modernista. Conforme o autor afirma em nota à segunda edição, o livro enfoca primordialmente a forma arquitetônica, o que parece coerente com a época em que foi escrito, quando ainda não estavam evidentes as questões sociais e simbólicas posteriormente levantadas, inclusive pelo próprio Venturi em "Learning from Las Vegas". Assim, em termos formais, Venturi, como os modernistas, busca precedentes históricos. Porém, se os modernistas, seguindo Le Corbusier, adotaram como paradigma a estética do templo grego, Venturi assume predileção pelo maneirismo, barroco e rococó, embora reconheça a complexidade presente na aparente simplicidade dos templos dóricos. Isto porque esta simplicidade visual resultava de um jogo sutil e complexo de distorções e contradições, perdido com os templos do período tardio.

Venturi crê que complexidade e contradição, aceitas em outras áreas, como artes, poesia e matemática, foram erroneamente suprimidas da arquitetura, com a adoção da linguagem modernista. Afinal, a arquitetura é complexa, por sua própria condição de considerar fatores distintos, em essência a tríade vitruviana - comodidade, firmeza e prazer. Se os modernos buscavam a linguagem uniforme e universal, Venturi defende, portanto, que a faceta formal da arquitetura deve aceitar e revelar toda sua complexidade, expondo-se não através da exclusão de elementos, mas através da inclusão de fatores que configurem uma totalidade, ainda que aparentem contraditoriedade quando isolados.

Para Venturi, que defende o equilíbrio através de opostos, os arquitetos modernistas evitavam a ambigüidade, pois a adoção da estética do "menos é mais" faz com que o arquiteto selecione aqueles problemas que deseja resolver, excluindo 


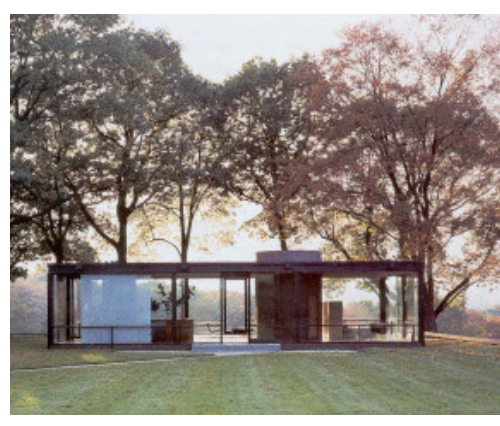

Fig 29. Glass house, de Philip Johnson; Connecticut, Estados Unidos.

38. BOTTON (2007) pp.184-185

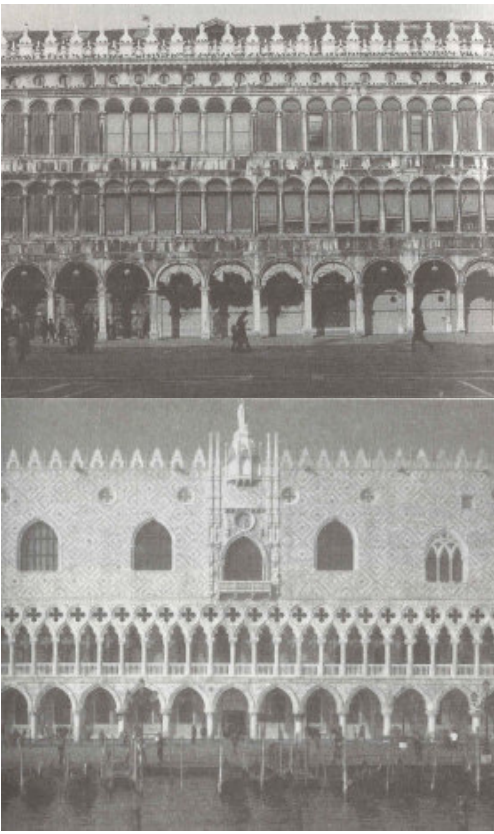

Figs 30 e 31. Procuratie Vecchie e Palácio do Doge; Veneza, Itália. outros e, com isso, correndo o risco de desvincular a arquitetura da vida cotidiana e das necessidades programáticas. Cita o exemplo das casas inspiradas nos pavilhões de exposições, como as de Philip Johnson, em que o cada vez mais complexo programa doméstico acaba simplificado. Não que Venturi não aceite a simplificação, mas o faz como método analítico, nunca como fim, assim como rejeita a complexidade superficial das formas deliberadamente pitorescas.

De Botton afirma que somos atraídos pela ordem quando vem acompanhada de complexidade, quando "janelas, portas e outros detalhes foram tecidos num desenho que consegue, ao mesmo tempo, ser regular e intrincado." 38 Para exemplificar, cita a Procuratie Vecchie e o Palácio do Doge, ambos na Praça São Marcos, em Veneza. Enquanto o primeiro apresenta constância na composição dos três pavimentos, o segundo atrai o olhar, pois ainda que exista ordem, há um desenho elaborado, que se alterna a cada pavimento de forma simultaneamente complexa e equilibrada.

À complexidade formal necessária à arquitetura, Venturi acrescenta a complexidade de significados, mais uma vez comparando aos níveis de significação presentes em outras manifestações. Tal qual na poesia ou na arte, na arquitetura complexa são constantes as tensões e ambigüidades, permitindo a percepção de significados diversos. Para ilustrar esta idéia, Venturi cita exemplos de edifícios que são "fechados, contudo abertos"; "simétricos, contudo assimétricos"; "simples, contudo complexos", etc, ou seja, situações formais que aceitam interpretações e compreensões distintas. Fala em "níveis contraditórios" ao propor a substituição da escolha entre uma opção ou outra, pela aceitação de níveis, "tanto uma coisa como outra". Venturi ilustra tal afirmação citando inúmeros exemplos de edifícios, especialmente barrocos e maneiristas, em que determinado elemento parece fora de lugar ou de proporção isoladamente, entretanto se ajusta de forma surpreendente ao conjunto, ou situações em que uma planta prevalentemente longitudinal pode ser percebida como transversal e vice-versa. Novamente, Venturi preza a inclusão em detrimento à exclusão modernista, valorizando níveis de significação aparentemente contraditórios que se alternam em prevalência, 


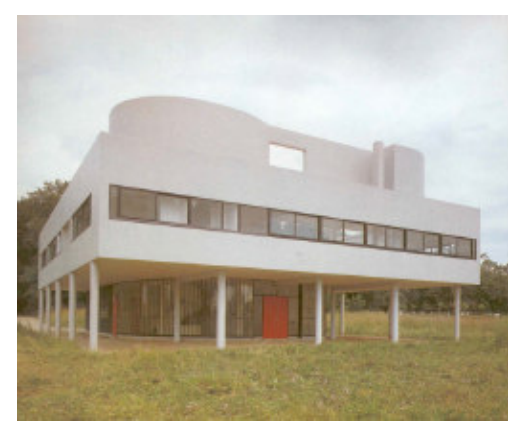

Fig 32. Villa Savoye, projeto de le Corbusier. Para Venturi aparentemente simples, porém tem interior complexo. Sua planta é simultaneamente quadrada e curva. Poissy, França.

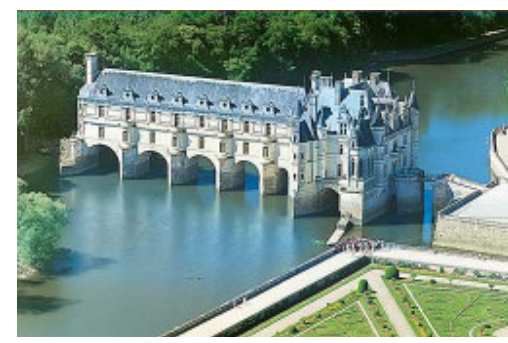

Fig 33. Castelo de Chenonceau. Edíficio de múltiplo funcionamento levado ao extremo. É edifício e ponte. Vale do Loire; França. de acordo com o percurso e a vivência no edifício.

Dentro do conceito de "níveis contraditórios", em paralelo à idéia de significados sobrepostos, Venturi estabelece o conceito de "elemento de duplo funcionamento", não sem antes mencionar edifícios de múltiplo funcionamento. Estes seriam edifícios não excludentes, que admitem funções variadas, ao contrário de certos edifícios que excluíam toda função que não fosse a de escritório, por exemplo. Assim, seriam edifícios de múltiplo funcionamento, entre outros, os famosos edifícios-fita de Le Corbusier que incluíam comércio, circulação de veículos e habitação, entre outras funções. Tanto o edifício quanto o cômodo multifuncional foram aceitos pela estética modernista que, no entanto, rejeitou o "elemento de duplo funcionamento". Para Venturi, a arquitetura moderna teria encorajado a separação total de funções, delegando formas e materiais específicos para funções específicas, por exemplo, ao promover a separação definitiva entre estrutura e fechamento, através das colunas aparentes em oposição aos panos de vidro das fachadas. Entretanto, Venturi aponta exemplos, mais uma vez na arquitetura barroca, de situações em que peitoris funcionam como pingadeiras e pilares possuem função simultaneamente estrutural e espacial, ou seja, constituem elementos tanto de sustentação quanto de composição formal. Por esta sobreposição de funções, estes elementos diferem do supérfluo, do ornamento. No entanto, Venturi considera que mesmo o ornamento exclusivamente estético, ou elemento retórico, ainda que em desuso, é válido se dotado de função expressiva na composição formal.

Ao decidir por determinada abordagem para o edifício, o arquiteto estabelece uma ordem que, para Venturi, deve acomodar as complexidades e contradições do projeto para que seja válida e não arbitrária. Porém, ao invés de valorizar a padronização modernista irrestrita, Venturi propõe dois caminhos, a "contradição adaptada" e a "contradição justaposta". A primeira é flexível, propõe modificações na ordem, como adaptação às questões apresentadas pelo espaço, estrutura e programa. A segunda é inflexível, baseia-se em forte contraste, na quebra de ordem. Em ambos os casos, acredita que esta quebra de ordem pode contribuir para trazer vitalidade ao edi- 
fício, realçando suas contradições.

Os conceitos trabalhados por Venturi, ainda que com aplicação restrita à forma arquitetônica, estão associados a conceitos hoje presentes na crítica à arquitetura e à sociedade contemporânea. O trabalho iniciado neste primeiro livro tem, de certa forma, continuidade em "Learning from Las Vegas", pesquisa escrita a partir de um estúdio realizado com estudantes e professores da Universidade de Yale, em 1968, adotando

39. Ficou conhecido como The Strip o trecho da Las Vegas Boulevard onde está a maioria dos cassinos. Esta via central cruza a cidade de Las Vegas.
Las Vegas e sua Strip $^{39}$, a via onde se localizam os principais cassinos, como paradigma para a análise do simbolismo na forma arquitetônica. Se no trabalho anterior Venturi tem foco no aspecto formal da arquitetura, em "Learning from Las Vegas", junto com Denise Scott Brown e Steven Izenour, volta-se para as questões simbólicas na arquitetura e no espaço urbano.

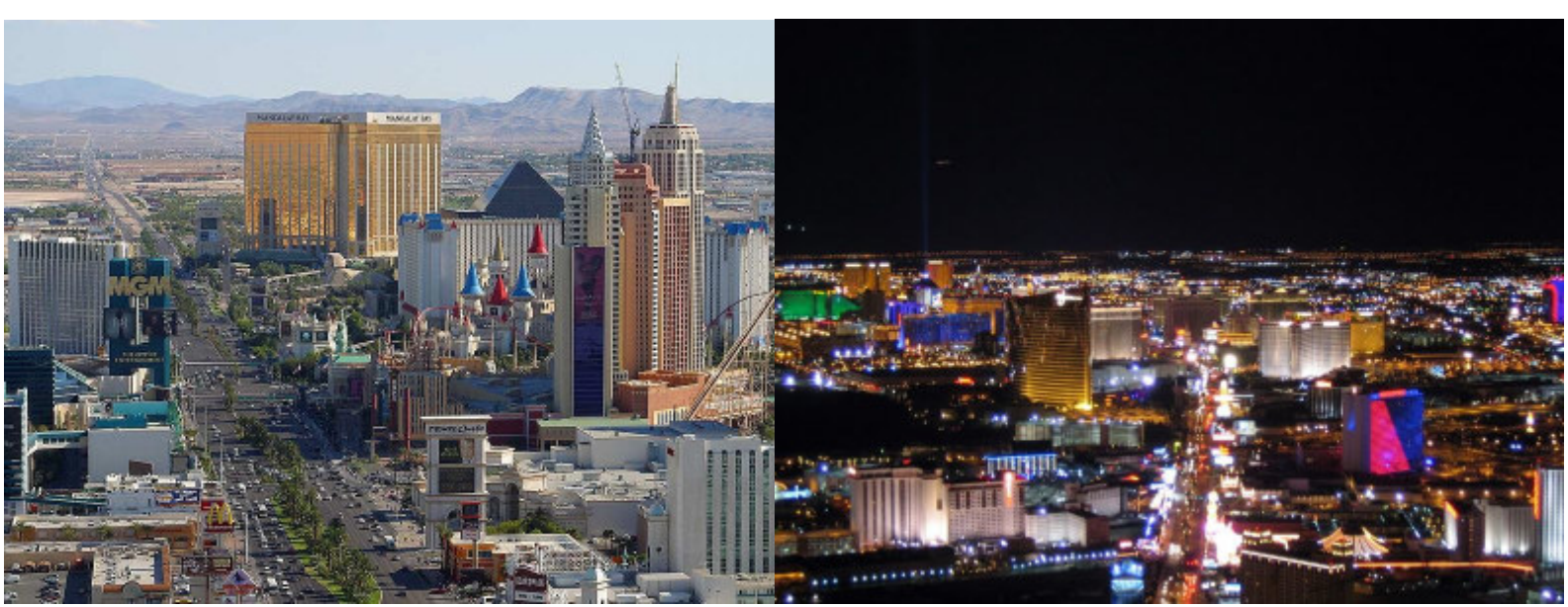

Figs 34 e 35. Parte sul da Strip durante o dia e parte norte, à noite.

No prefácio à segunda edição, Scott Brown conclui que o aprendido com Las Vegas não foi o hábito de acrescentar grandes placas de referencial imediato em todos os edifícios, mas se aprendeu a repensar o papel do simbolismo na arquitetura e aceitar os gostos e valores de outras culturas, olhando com menos pretensão o papel da arquitetura na sociedade. Com esta afirmação, Scott Brown retoma a crítica à arquitetura moderna então recente, dita uniforme e de pouca vitalidade. A esta crítica soma-se a de que a arquitetura moderna trazia consigo a proposta radical de mudar completamente a paisagem existente, tal qual o já citado Plan Voisin de Le Corbusier para Paris, ao invés de aprender com o que 
existe, promovendo melhorias mais coerentes.

Talvez seja este o primeiro trabalho a mencionar diretamente a presença do temático na arquitetura e, muito provavelmente, também por isso, o texto esteve sempre carregado de polêmica, mas inevitavelmente a crítica pode voltar-se à validade da análise feita, defendendo que o exemplo principal - o cassino - teria moral questionável. A respeito do jogo e da arquitetura como elemento de persuasão para tal, os autores fizeram questão de destacar que não estão em questão os valores morais associados aos cassinos, e sim o método adotado em suas arquiteturas, mesmo porque não se trata de um livro sobre cassinos e sim sobre esta nova apresentação do simbolismo na arquitetura.

Retomando o paralelo com a arquitetura moderna, o texto identifica que esta arquitetura "limpa" não encontra espaço para placas e sinalizações, vistas como interferências e restritas ao mínimo possível; afinal, para os modernos, o significado da arquitetura deveria ser transmitido através de sua própria forma, e não de símbolos previamente conhecidos. Aqui poderíamos retomar a citação de Scully, que questiona se a própria arquitetura moderna não teria se convertido em símbolo auto-referencial. Ao reproduzir-se seguindo padrão universal, a arquitetura moderna acaba por fazer referência a algo já conhecido e a própria linguagem moderna inevitavelmente torna-se forma previamente conhecida.

Assim, se para os modernos a arquitetura deve ser tida como espaço e a comunicação deve vir da forma, em Las Vegas teríamos a sobreposição da comunicação sobre o espaço, com a arquitetura em segundo plano. Evidentemente, tratase de outra escala - do automóvel, mais veloz e aberta - e outro contexto - essencialmente comercial. Se na escala do mercado medieval ou da Main Street a comunicação podia ser verbal, ou através das vitrines e de pequenas placas, a escala de Las Vegas demanda a comunicação através de placas e outdoors significativamente maiores que, inclusive, comunicam mais que o próprio edifício, de arquitetura dita neutra, pouco visto e encoberto pelos estacionamentos. Estas placas fazem uso de mídias diversas - na época, figuras, textos, esculturas, iluminação; hoje, também o vídeo é utilizado. Podemos iden- 
40. VENTURI, SCOTT-BROWN e IZENOUR (2001) p.13 "Symbol dominates space. Architecture is not enough. Because the spacial relationships are made by symbols more than

by forms, architecture in this

landscape becomes symbol in space rather than form in space." tificar a escala do mercado ainda presente, porém, no interior dos cassinos. Por outro lado, são estes enormes elementos de sinalização que trazem a unidade ao aparente caos da Strip. Os autores identificam, portanto, uma preponderância simbólica inédita; o símbolo avulso, descolado da arquitetura, torna-se mais importante que o próprio edifício, conforme afirmam:

"O símbolo domina o espaço. A arquitetura não é suficiente. Como as relações espaciais são feitas mais por símbolos que por formas, a arquitetura nessa paisagem se torna um símbolo no espaço, ao invés de forma no espaço." ${ }^{40}$

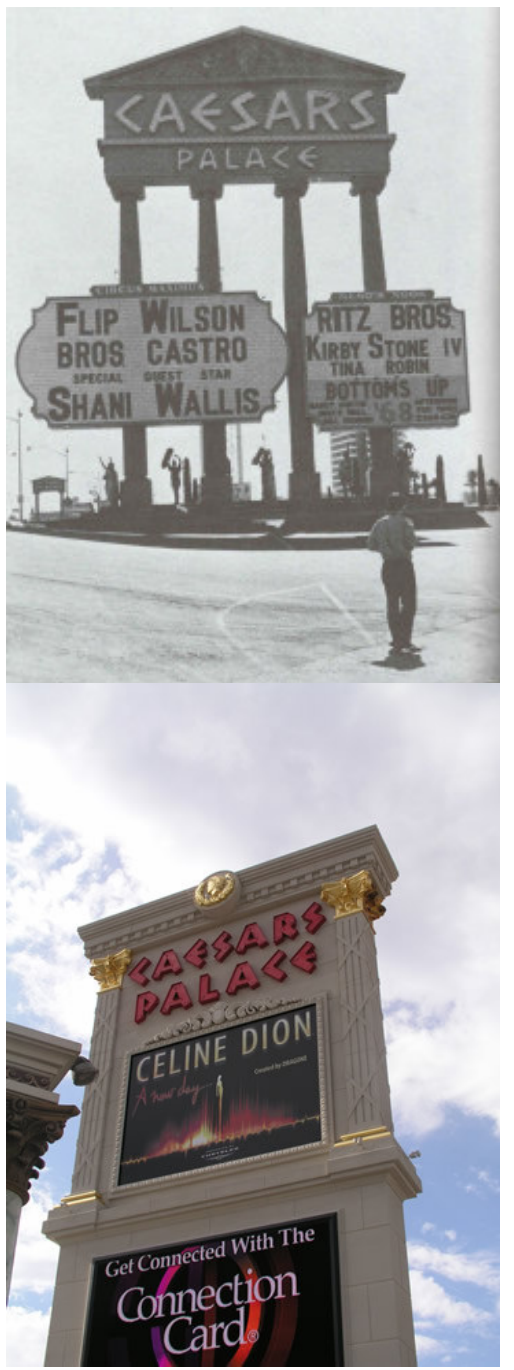

Figs 36 e 37. Placa do hotel-cassino Caesar's na época do levantamente feito por Venturi e nova placa, já com vídeo.

41. Idem p.106.

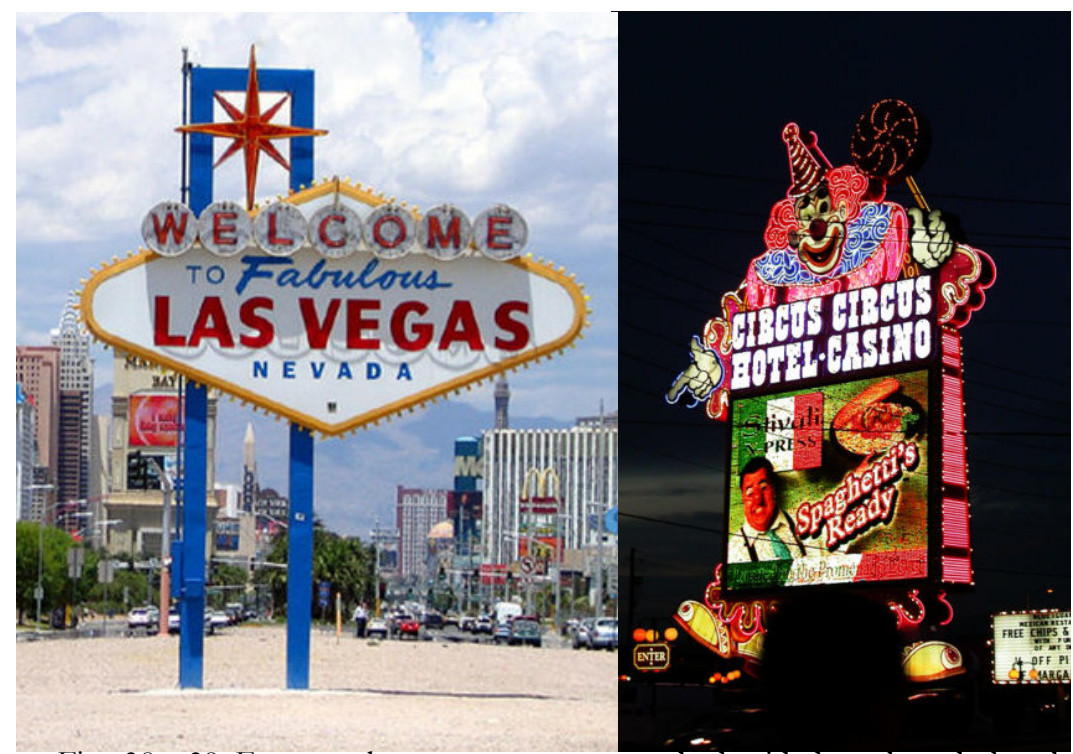

Figs 38 e 39. Famosa placa que marca a entrada da cidade e placa do hotelcassino Circus Circus, em forma de palhaço.

Venturi cita casos em que o símbolo sobrepõe-se a ponto de a arquitetura assumir a função de sinalização, como o do restaurante concebido em formato de pato, em um caso, segundo os autores, análogo ao do domo barroco que era simultaneamente construção e símbolo. Hoje, percebemos que este exemplo, na época da pesquisa ainda exceção, tornou-se praticamente regra em Las Vegas. Os autores deixam transparecer a percepção desta tendência quando afirmam que, em Las Vegas, o simbólico evolui seguindo a tendência de que o edifício seja cada vez mais sinalização e menos arquitetura ${ }^{41}$. Hoje, com o acréscimo assumido do tema, todos os grandes cassinos são construídos e/ou remodelados segundo uma arquitetura de prevalência do símbolo de apreensão imediata, previamente conhecido e de rápida associação com a temática adotada. Para citar alguns exemplos, temos o hotel-cassino 
Luxor, construído com a forma de uma pirâmide egípcia, o Excalibur, um castelo medieval, ainda que de proporções bastante alteradas, ou o Circus Circus, com uma "tenda circense".

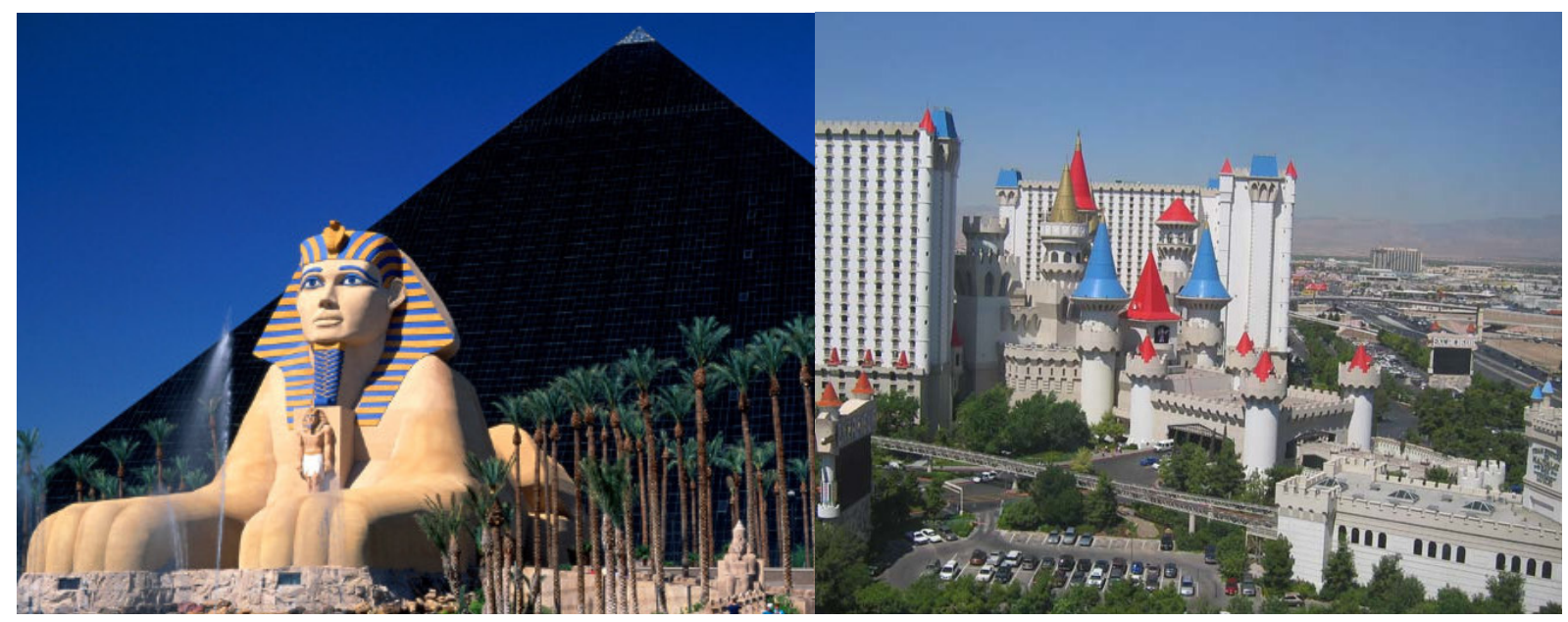

Figs 40 e 41. Cassinos Luxor e Excalibur.

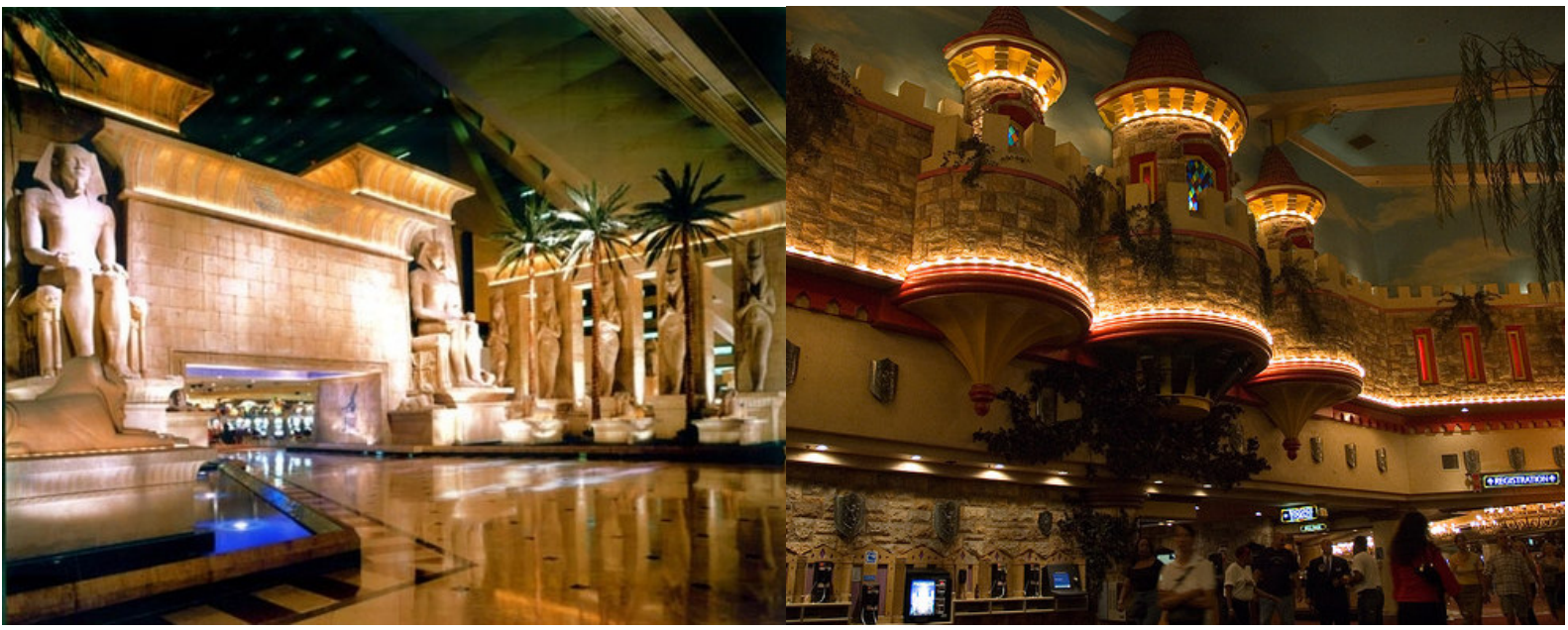

Figs 42 e 43. Interior dos cassinos Luxor e Excalibur.

Embora a pesquisa esteja focada no simbolismo, e não propriamente no ornamento, os dois estão intrinsecamente relacionados. Ao comentar a durabilidade das fachadas e placas de sinalização da Strip, mais próxima a do automóvel que do edifício, os autores mencionam a necessidade constante de renovação para equiparação aos concorrentes, tanto pelo tamanho quanto pelo acréscimo de ornamentos que fazem com que suas placas e fachadas sobressaiam. Nesta época, as fachadas frontal e direita, mais visíveis aos veículos, recebiam tratamento mais elaborado, enquanto a esquerda recebia algo mais simplificado, e a fachada de fundos, não vista, era totalmente negligenciada. O elemento constante seria a estrutura interior "neutra". Avaliando os cassinos mais recentemente, percebe- 
mos que também este interior recebe revestimentos temáticos, assim como as fachadas, já que, hoje, os estacionamentos circundam as edificações, permitindo a visibilidade total do edifício.

Esta diferenciação pelo tema, ainda que não total como hoje, já estava presente nas fachadas no período de pesquisa para o livro e, por isso, os autores afirmam que é difícil não pensar cada cassino com algo único; a própria propaganda característica desta arquitetura de persuasão requer a diferenciação do produto. Entretanto, também afirmam que, ao mesmo tempo, os cassinos trazem muito em comum. Sobre isso, podemos citar Bourdieu e sua afirmação de que no campo de produção erudita, mas, principalmente no campo da indústria cultural, a busca irrestrita por diferenciação pode induzir aos mesmos critérios, levando à igualdade. ${ }^{42}$

Para Venturi, o cassino de Las Vegas é uma combinação. Se o complexo programa costuma incluir atividades diversas como jogo, restaurantes, boites, habitação temporária, lojas, etc, o estilo também reflete uma combinação de elementos e referências. O texto cita o exemplo do hotel-cassino Caesar's, com a temática 'Roma antiga', então um dos maiores da cidade, cuja arquitetura combina elementos romanos, etruscos, barrocos, etc. Podemos destacar que o referencial adotado pelo temático comporta elementos de fácil identificação pelo público em geral, ou seja, um cassino de temática associada à Roma Antiga irá trazer como referência tudo aquilo que entendemos e identificamos como romano, independentemente de ser historicamente verdadeiro ou compatível.
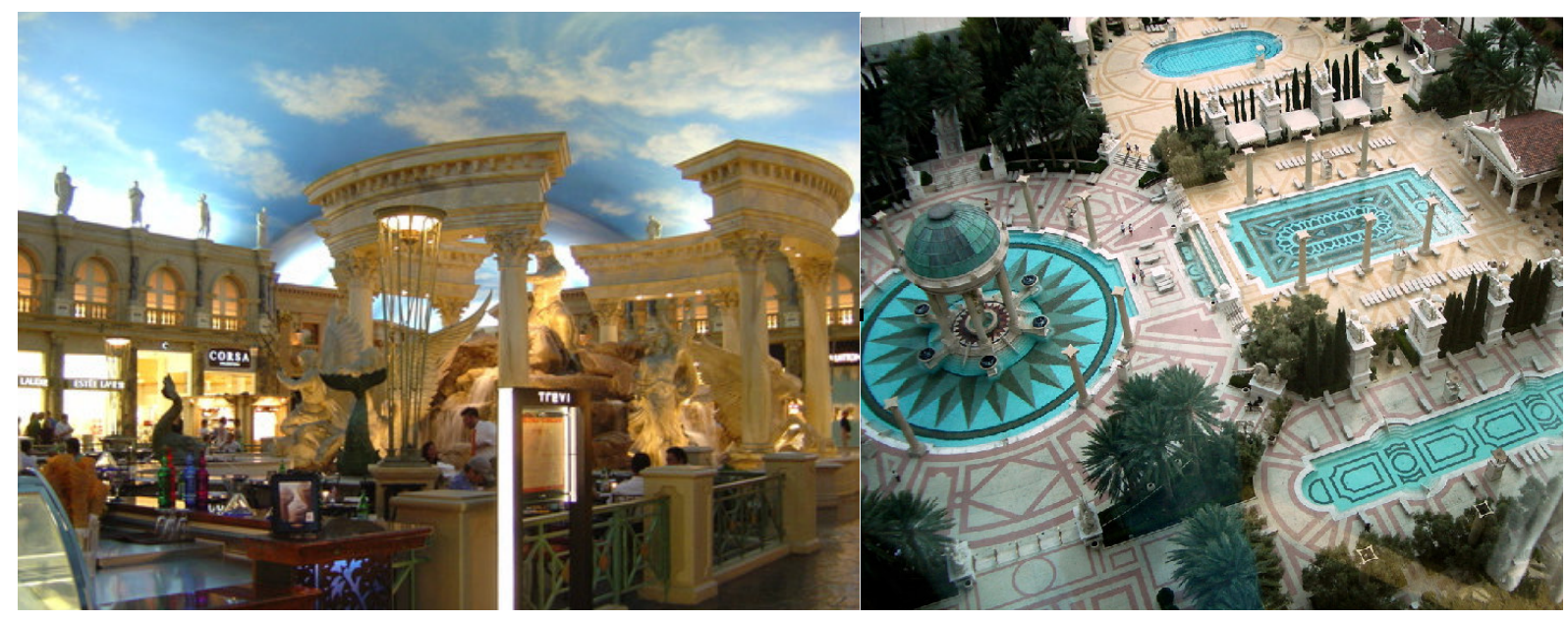

Figs 44 e 45. Hotel-cassino Caesar's. 
43. VENTURI, SCOTT-BROWN e IZENOUR (2001) p.53

"For the architect or urban designer, comparisons of Las Vegas with others of the World's "pleasure zones" (...) suggest that essential to the imagery of pleasure-zone architecture are lightness, the quality of being an oasis in a perhaps hostile context, heightened symbolism, and the ability to engulf the visitor in a new role: for three days one may imagine oneself a centurion at Caesars Palace, a ranger at the Frontier, or a jetsetter at the Riviera rather than a salesperson from Des Moines, Iowa, or an architect from Haddonfield, New Jersey."
A ausência de luz natural no interior dos cassinos elimina qualquer referência temporal. Ao mesmo tempo, o uso de paredes que absorvem a luz, associado à configuração labiríntica do interior dos cassinos e ao uso de ar condicionado confere a sensação de espaço infinito. Essa quebra de vínculo com o exterior, apontada pelos autores como elemento da arquitetura de persuasão em Las Vegas, favorece a longa permanência do apostador e constitui característica essencial do entretenimento temático.

Embora não estabeleçam o conceito de "temático" realmente não é este o foco da pesquisa - os autores identificam Las Vegas com outros centros de lazer:

"Para o arquiteto ou urbanista, a comparação entre Las Vegas e outras das “zonas de prazer" mundiais (...) sugere que são essenciais para a arquitetura das zonas de prazer a iluminação, ser um oasis em meio a um contexto hostil, simbolismo elevado e a habilidade para envolver o visitante em um novo papel: por três dias alguém pode se imaginar um centurião no Caesar's Palace, um desbravador noFrontier, ou um jetsetter no Riviera, ao invés de um vendedor de Des Moines, Iowa, ou um arquiteto de Haddonfield, New Jersey." ${ }^{43}$

Entretanto, afirmam que mais importante do que esta constatação é a de que a arquitetura de Las Vegas alcança vitalidade e que, fazendo referência ao conceito trabalhado em "Complexidade e Contradição em Arquitetura", consegue esta vitalidade porque inclui, ao invés de excluir. Acrescentam, ainda, que Las Vegas evidencia o valor do simbolismo e da referência na arquitetura e prova que mesmo arquitetos se divertem com esta arquitetura carregada de lembranças.

A partir de Las Vegas, os autores identificaram duas possibilidades principais de manifestação do simbólico na arquitetura. No primeiro caso, o próprio edifício é tratado como símbolo, sua estrutura depende da forma simbólica. Seria o caso do já citado edifício em forma de pato. No segundo caso, a estrutura, o abrigo, recebe aplicação de ornamentos que conferem simbologia. Venturi chama esta situação de "decorated 44. Idem p.87. shed", algo como galpão decorado. ${ }^{44}$ Para os autores, ambas as situações são válidas, embora a primeira raramente seja rele- 


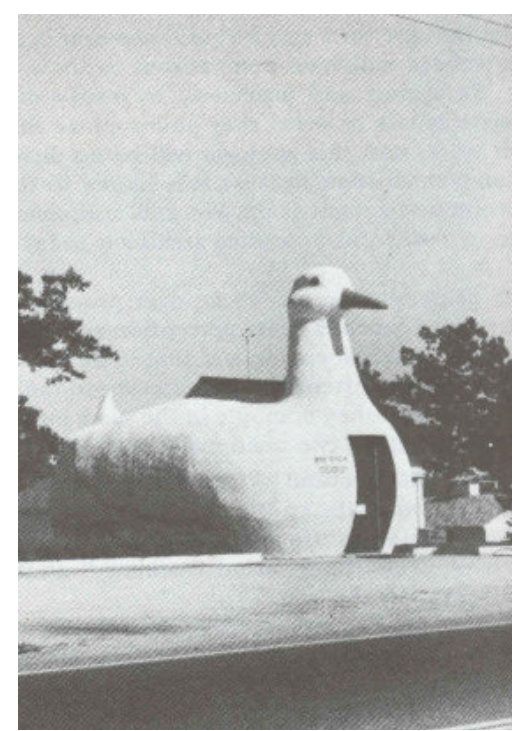

Fig 46. Edifício-pato.

45. EISENMAN, Peter. O fim do clássico: o fim do comeco, o fim do fim. In. NESBITT (2006) p.235.

46. VENTURI, SCOT'T-BROWN e IZENOUR (2001) pp.113-114 vante e esteja claramente expressa uma predileção pelo galpão decorado, dita mais coerente com a época em que se encontravam, caracterizada pela mídia da sinalização, mais prosaica, porém mais flexível em termos de escala e mais adaptável que o simbolismo heróico representado pelo edifício-pato. Seguindo esta lógica, concluem que a arquitetura moderna está próxima do modelo "pato", pois, ao rejeitar a aplicação de ornamentos e simbologia explícita, converte a edificação em um ornamento em si.

Anos mais tarde, Eisenman concorda com Venturi na predileção pelo galpão decorado, ao afirmar que:

"Uma construção do tipo "pato" é aquela que aparenta a sua função ou que revela na aparência exterior a sua ordem interna. Um "galpão decorado" é uma construção que funciona como um grande outdoor, onde qualquer tipo de imagem, (exceto a função interna do prédio) - letreiros, padrões, e mesmo elementos arquitetônicos - transmite uma mensagem acessível a todos. Desse ponto de vista as despojadas "abstrações" modernistas ainda são objetos referenciais: são "patos" tecnológicos em vez de tipológicos." $" 45$

Ainda seguindo a lógica desta simbologia apreendida em Las Vegas, o texto traça um paralelo com diversas arquiteturas do passado, avaliando a presença do ornamento como símbolo em cada uma delas. A pesquisa identifica as catedrais medievais com os dois modelos identificados. A catedral é um símbolo em si, já que seu significado simbólico para a cidade medieval tem preponderância sobre sua estrutura, mas também recebe aplicação de ornamentos, relevos escultóricos. Já a arquitetura renascentista e barroca dos Palaz:os seria um exemplo fiel do modelo galpão decorado, com suas fachadas retas, porém ornamentadas com rusticações, colunas, etc. Sobre o ecletismo característico do século XIX, afirmam ter sido um período de "simbolismo da função" ", ou seja, um período em que a simbologia associada à arquitetura servia para tornar mais evidente a função do edifício. É citado o exemplo dos edifícios bancários, comumente construídos fazendo referência à basílica clássica para sugerir responsabilidade e tradição. Em relação ao ornamento na arquitetura moderna, relatam 
que, embora existisse - como no caso dos pilares em "I" - raramente fazia referência a elemento não arquitetônico. De um modo geral, a referência onipresente na arquitetura moderna era a evocação da tecnologia da Revolução Industrial. Portanto, existia um simbolismo na arquitetura moderna e a grande crítica que fazem aos modernistas é em relação à recusa destes em admitir esta presença do simbólico.

Assim, "Learning from Las Vegas" lembra que, com mais ou menos evidência, o ornamento sempre teve relevância na composição arquitetônica e, com isso, critica a visão moderna de Mies sobre a tríade vitruviana de que firmeza e comodidade resultariam em beleza, como se esta fosse mera conseqüência da adequação tipológica ao programa e estrutura da edificação. Destaca, ainda, que em nada diminui o trabalho ou importância do profissional arquiteto sua aproximação com a cultura popular, muito pelo contrário, o reforço desta relação, possivelmente pelo viés da ironia, poderia aproximar o arquiteto do cliente e a arquitetura do público. Seria, então, hora de acatar e avaliar a presença do ornamento, do elemento simbólico na arquitetura, como algo potencialmente positivo. O pioneirismo do texto em aceitar a presença do simbólico, inclusive do figurativo, na arquitetura recente o torna fundamental para esta pesquisa.

1.4 Anos mais tarde, já com a transformação dos cassiArquitetura e ilusões nos e locais de entretenimento de um modo geral em espaços assumidamente temáticos, Ada Louise Huxtable retomou a discussão iniciada por Venturi, Izenour e Scott Brown, desta vez tratando dos mundos de fantasia construídos pela arquitetura norte-americana mais recente, no livro "The Unreal 47. HUXTABLE (1993). America - Architecture and Illusion”, de $1993 .{ }^{47}$ No prefácio do texto, Huxtable explica que não nega a demanda por espaços "artificiais" e nada tem contra a ilusão, mas que o cerne de sua preocupação está na transformação da história em fantasia, do ambiente em entretenimento, e em como esta transição afeta nossa visão sobre passado, presente e suas realidades.

A autora deixa claro que não busca o entendimento filosófico sobre o conceito de realidade, já que trata de algo mais concreto, a realidade do mundo que optamos por cons- 
truir e como esta escolha nos afeta. Para Huxtable, a opção pela fantasia e ambientações construídas, em detrimento à verdade do local e seu passado, promove satisfação, porém limitada e ilusória. Neste modelo, a interação entre edificação, entorno e sociedade seria ignorada ou invertida, por exemplo na construção da réplica de Nova York em um cassino de Las Vegas. Essa predileção do público pelo fake seria responsável pela barreira que nos impede de receber positivamente o que Huxtable chama de "arquitetura séria". Entretanto, faz questão de afirmar que seu objetivo não é rejeitar ingenuamente o modelo temático, mas questionar se esta demanda é fato, ou se apenas aceitamos a arquitetura que vem sendo oferecida por ser mais interessante em termos mercadológicos.

Huxtable diz não saber exatamente desde quando, mas identifica que, em algum momento, a realidade deixou de ser a única opção, resultando inicialmente na possibilidade de ampliá-la e, logo, revisá-la, substituindo-a pela fantasia cuidadosamente selecionada. Especialmente nos Estados Unidos, a conversão de espaços históricos em entretenimento temático tem se mostrado bastante lucrativa, de acordo com o exemplo citado como um dos primeiros e mais replicados, a cidade de Colonial Williamsburg, modificada em 1920.

Huxtable relata que sua restauração partiu do princípio de que era necessário estabelecer um recorte temporal, no caso 1770. Com isso, construções posteriores à esta data foram removidas, independentemente de seu valor histórico, e substituídas por outras, movidas para o terreno esvaziado, ou reconstruídas, mesmo que já não existissem há tempos, caso do Capitólio. A cidade parece ter sido restaurada de acordo com o que imaginavam ter sido, ou, o mais arriscado e provável, de acordo com aquilo que gostariam que tivesse sido. Para completar o cenário, os interiores foram reconstruídos com peças em sua maioria não originais, e elementos de produção foram acrescidos para consolidara sensação de viagem no tempo, entre eles carruagens, atores em roupas de época e mesmo animais. O projeto foi apresentado como uma "reprodução autêntica", paradoxal termo duramente criticado pela autora, uma vez que, por definição, a réplica não pode coincidir com o original. Mesmo porque, era praticamente impossível 
48. MIDDLETON (2002) tabela 21.1 p.386. parques temáticos quanto em museus. ${ }^{48}$

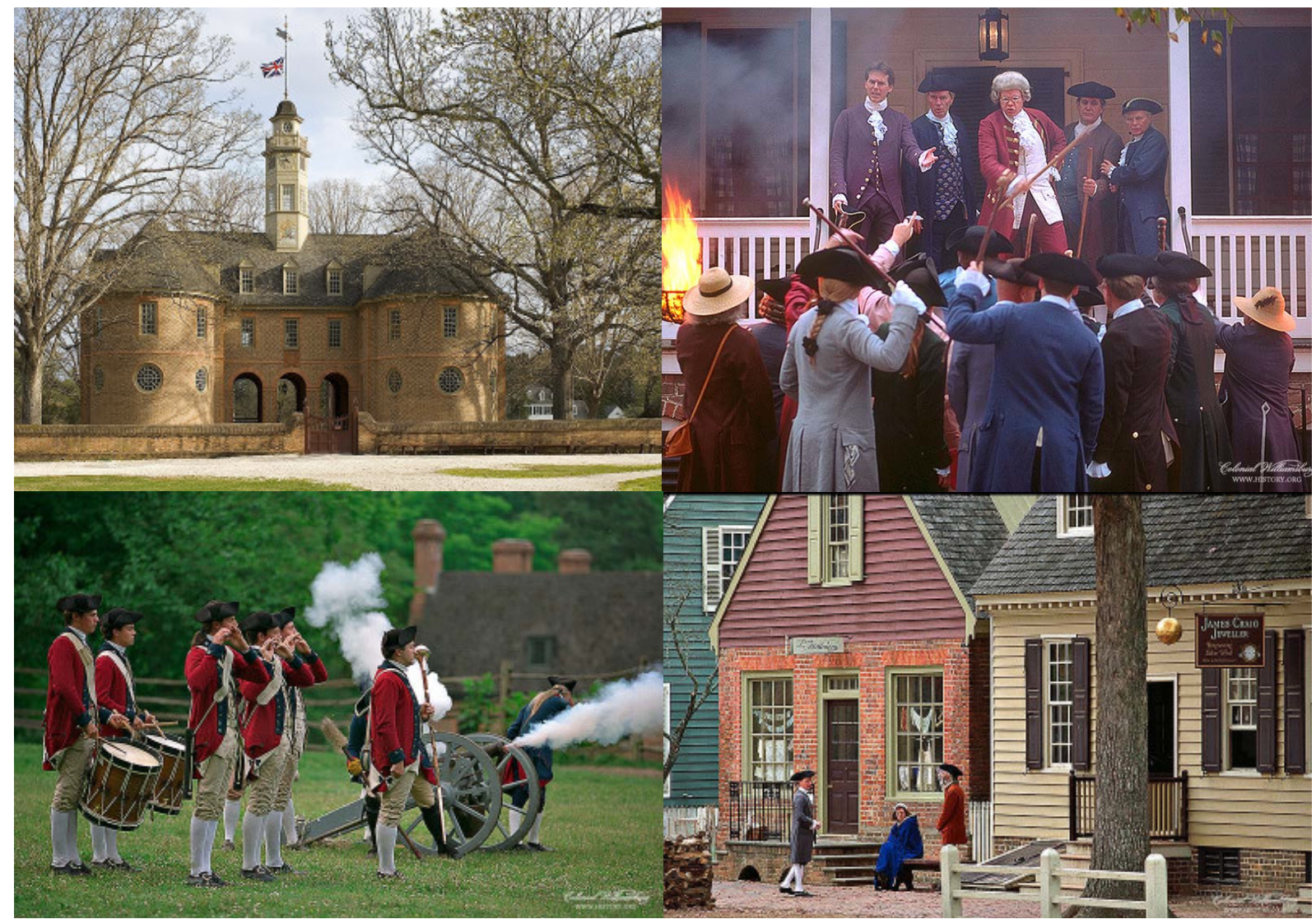

Figs 47, 48, 49 e 50. Colonial Williamsburg: capitólio, encenações de discussão e batalha e cena cotidiana.

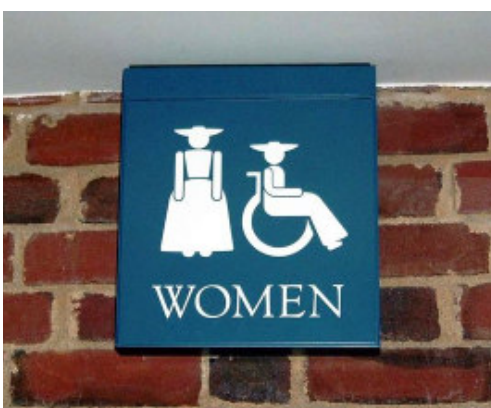

Fig 51. Sinalização de sanitário em Colonial Williamsburg.

49. AUGÉ, Marc. Contemporary tourist experience as mise-en-scène. In. FRAUSTO e OCKMAN. (2005) p. 91 "as a result, what we are looking at is really just the spectacle of ruins. (...) we are looking at a scene constructed in and for the present time."

não submeter os documentos históricos à interpretação, e dificilmente o resultado seria uma réplica semelhante ao original. A conotação de Colonial Williamsburg é tão ambígua que Middleton, ao listar os dez principais tipos de atrações gerenciadas abertas ao público, a cita como exemplo tanto em

parques temáticos quanto em museus. ${ }^{4}$ 
contrapartida, teríamos aprendido com Williamsburg que o passado não deve ser encarado apenas como um lugar, mas como um processo cuja arquitetura deve estar vinculada ao contexto social. Argumenta, também, que mesmo a chamada "preservação histórica", ao eliminar imperfeições, apaga as marcas da história, edita a memória. Assim, de uma forma ou de outra, é constantemente inventado um novo passado para satisfazer nossas necessidades e valores estéticos. O ideal seria, então, preservar o passado integrando-o dinamicamente ao contexto contemporâneo, principalmente no que se refere aos edifícios remanescentes nas grandes metrópoles. Eles poderiam receber usos distintos do original, apropriados à realidade contemporânea, e seriam adequados a estes novos usos, mas, segundo Huxtable, o resultado, se não perfeito, seria, ao menos, real.

De Williamsburg para a Disneyland foi um pequeno passo. Assim como a cidade, os parques apresentam uma ilusão verossímil, oferecendo a chance de se aproveitar com segurança e conforto locais e épocas de acesso difícil ou inviável. A temática adotada pelos parques é diversa e abrangente, praticamente qualquer assunto é passível de reinvenção. Huxtable relembra que boa parte da paisagem norte-americana foi construída com base na fantasia, desde as avenidas retilíneas de Manhattan, passando pelos resorts da Flórida com suas palmeiras importadas, até as novas comunidades suburbanas planejadas sob a ótica do New Urbanism. Porém, se estas cidades devem apresentar um planejamento social e urbano funcional, permitindo seu desenvolvimento e expansão futuros, os parques temáticos crescem para suprir a demanda mercadológica. Esta exploração temática dos parques já foi, inclusive, transposta para museus e sítios históricos sob o pretexto educacional.

Huxtable relata sua decepção ao visitar a Disneyland e encontrar, por trás das fachadas cuidadosamente construídas da Main Street, interiores uniformes, vendendo os mesmos souvenirs, descritos como exemplares do brega mais corriqueiro. No entanto, demonstra apreciação pelo então recente complexo da Universal Studios, em Los Angeles, o Universal City Walk. Descrito como um híbrido de shopping center e parque temático, 
50. Ver capítulo 2.2

51. Além dos parque locais, o oriente conta com filiais da Disney. O Tokyo Disney Resort comemorou 25 anos em abril de 2008. Atualmente conta com dois parques, hotéis, lojas e restaurantes.

A Hong Kong Disneyland foi inagurada em 2005, com um parque e dois hotéis.

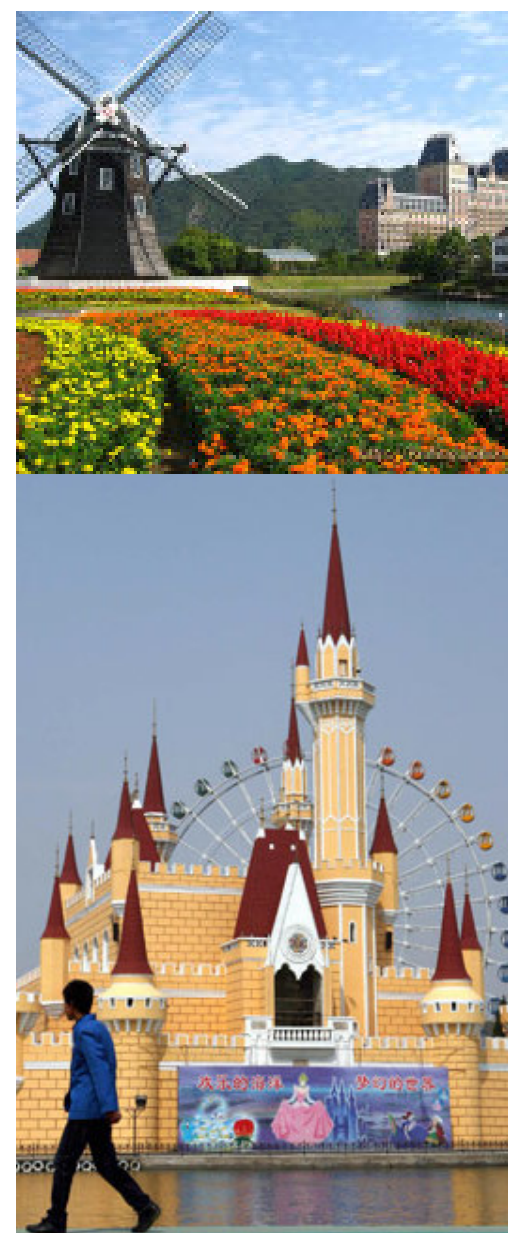

Figs 52 e 53. Huis Ten Bosch, parque temático japonês que reproduz a Holanda. Shijingshan, parque Chinês "inspirado" na Disneyland.

52. Ver capítulo 3.3

53. Ver capítulo 3.4 o City Walk remete ao espaço público da rua e inclui atividades como bares, restaurantes, livrarias e cursos, em um contexto mais dinâmico, emoldurado por fachadas resultantes de colagem de referências arquitetônicas a edifícios reais. ${ }^{50} \mathrm{~A}$ autora conclui que o modelo estabelecido pela Disney pode ser aprimorado e, ainda que provoque desconforto, seria ingenuidade negar seu espaço na cultura norte-americana contemporânea. Hoje, talvez possamos estender a afirmação de Huxtable à cultura globalizada contemporânea, já que o temático avança inclusive em países ocidentais como Japão e China. ${ }^{51}$

Comparando os visitantes dos parques temáticos, Huxtable vê, como ponto comum, a busca pelo lazer com segurança e conforto em locais limpos e homogêneos. A oferta dos parques, portanto, vai além do souvenir fatalmente comercializado, a maior oferta é a possibilidade de lazer despreocupado de longa duração, por no mínimo um dia inteiro, sem a ocorrência de qualquer imprevisto indesejado. Para os que permanecem por mais tempo, há oferta de veículos que levam diretamente aos hotéis, igualmente temáticos, de maneira que resta ao turista pouca ou nenhuma preocupação além de comprar a passagem. Não há limites para esta oferta de entretenimento; os parques incluem em seus complexos hotéis temáticos para todos os gostos, clubes, campos de golfe, entre outros atrativos, ou seja, como as cidades do passado, esta paisagem é construída com base no fantástico, mas com o único propósito de entreter e, conseqüentemente, lucrar.

Com a crescente violência e decadência urbana, aparece uma inversão do modelo temático. A imagem almejada por todos é hoje a da comunidade romântica do passado e Huxtable entende que, a partir do momento em que as cidades são remodeladas seguindo esta imagem, o real passa a imitar a imitação. Orlando, a cidade mais próxima ao Walt Disney World, está repleta de restaurantes temáticos e inúmeras pequenas cidades remodelaram suas Main Streets de acordo com a original Disney. ${ }^{52}$ A própria Disney projetou em seus domínios uma espécie de cidade temática, Celebration, onde estilos distintos são aplicados a projetos padronizados de residências, todos em harmonia, segundo a propaganda do local. ${ }^{53}$ Para Huxtable, trata-se de um exemplo em que a coisa errada está 
54. HUXTABLE (1993) p.71 "(...) the thing imitated is no better than the copy, and the reverse may be taken to be true. Las Vegas, an act of total artifice, pretends to be nothing but itself.'"

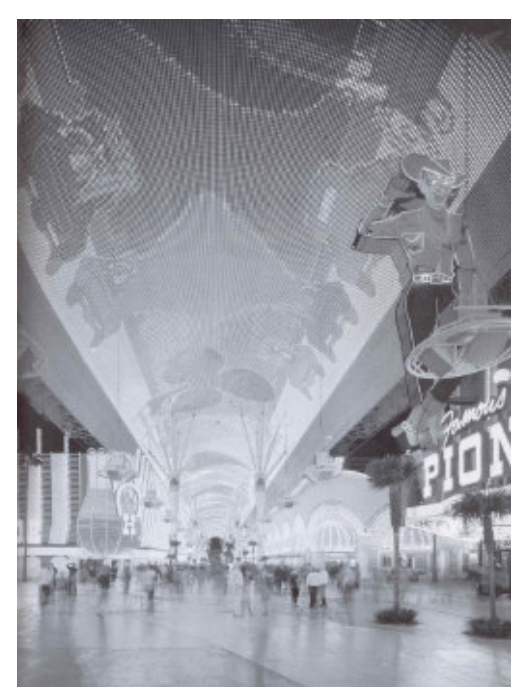

Fig 54. Freemont Street.

sendo feita da forma correta, pois o projeto conta com especialistas bem preparados. Uma tematização análoga já ocorria em muitos subúrbios norte-americanos, em que a ilusão de status era vendida em residências cuja arquitetura remetia à grandiosidade de arquiteturas do passado. A conclusão de Huxtable é de que o mundo irreal tornou-se bastante real, conforme percebemos em sua afirmação: “(...) a coisa imitada não é melhor que a cópia, o contrário também pode ser tido como verdade. Las Vegas, um ato de artificialidade, finge ser nada mais que ela mesma." 54

A questão já não seria o confronto entre real e falso, mas entre o bom e mau falso, sendo bom aquele que promo55. Ver capítulo 5.1 ve melhorias em relação à realidade. ${ }^{55}$ Huxtable classifica o "fake fake" e o "real fake", este representado por locais como Las Vegas, onde, conforme apontaram Venturi, Scott Brown e Izenour, foi desenvolvido um vocabulário arquitetônico novo que atende às demandas comerciais e sócio-culturais emergentes. Huxtable entende que reside nos complexos de entretenimento, como os cassinos de Las Vegas, a nova fronteira do planejamento urbano. O objetivo tão perseguido durante anos por urbanistas de valorizar o pedestre e projetar em sua escala está, em certo ponto, atingido no interior destes complexos. Cita, ainda, o exemplo da Fremont Street, que em "Learning from Las Vegas", ainda era a área antiga e ultrapassada da cidade, e nesse momento havia sido convertida em uma vibrante via para pedestres, envolvida em um show de som e luz produzido por computação gráfica.

A cidade, originalmente voltada para o público adulto, é agora identificada com o entretenimento familiar, pois os cassinos incluem shoppings, casa de shows, parques, tudo envolvido pela temática explorada. Huxtable chama atenção para o que então ainda estava em projeto, o complexo New York New York, em que edifícios famosos e marcos urbanos e históricos de Manhattan localizam-se lado a lado, unificados por uma montanha russa que percorre esta arquitetura.

Cada complexo costuma promover shows periódicos relacionados à temática explorada, batalhas entre piratas em um mar artificial, ou explosões vulcânicas em pleno deserto. A questão se complica quando a experiência artificial torna-se 


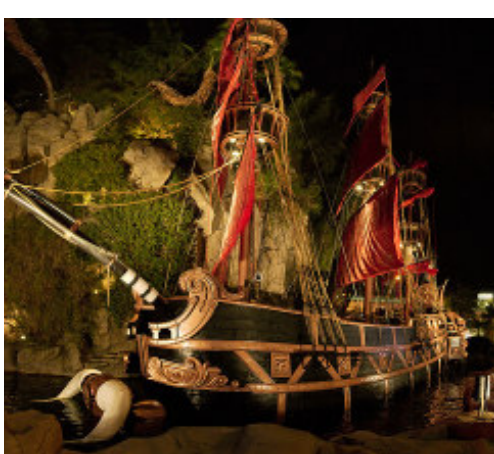

Fig 55. Barco usado como cenário do show Sirens of TI, apresentado diariamente na entrada do hotelcassino Treasure Island.

56. HUXTABLE (1993) p.86

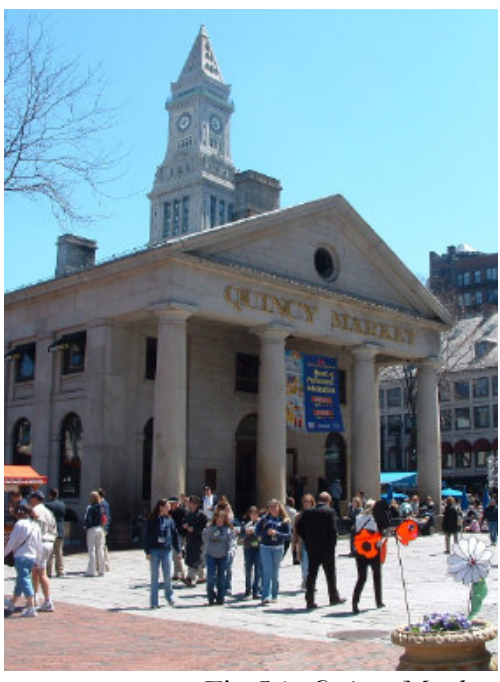

Fig 56. Quincy Market.

57. Idem p.95.

da autenticidade reconhecida por Huxtable, já que, embora antigo, pois data de 1820, trata-se de um edifício em etilo "neogrego" que poderia ser visto como temático não houvessem passado quase dois séculos de sua construção. Poderíamos nos perguntar se a antiguidade é suficiente para conferir autenticidade, a partir do momento em que uma referência aparentemente arbitrária - no Quincy Market, a Grécia - pode ser reconhecida como parte da época em que o edifício foi construído. Neste caso, estaríamos próximos da tendência identificada por Stephen Fjellman de que o futuro dos Parques Temáticos, ou pelo menos de Walt Disney World, é ser convertido 


\section{FJELLMAN (1992) p.403. em museu. ${ }^{58}$}

Ver capítulo 3.3

59. CRAWFORD, Margareth. The world in a shopping mall. In SORKIN

(2001)

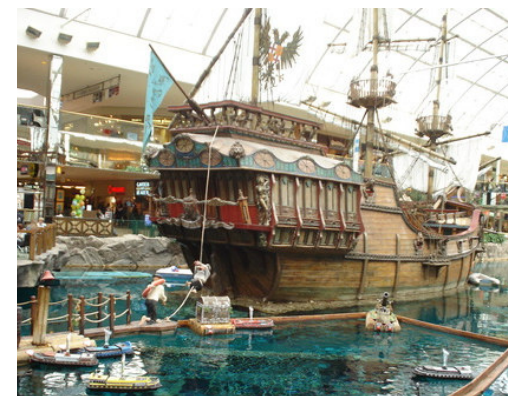

Fig 57. Navio pirata em West Edmonton Mall. O maior shopping do mundo tem entre suas atrações parque de diversões, parque aquático, rink de patinação, shows,

etc.

Huxtable alerta, também, para o que Margaret Crawford chama "successful package of authenticity" 59 , em que a arquitetura original é "melhorada" para ser exaltada como atrativo, mas é fato que a conversão de muitos edifícios históricos em áreas comerciais permitiu sua preservação. Entretanto, a transposição do valor único da arquitetura histórica para o objeto comum à venda pode equipará-los, deturpando o valor da própria arquitetura original. Existe, ainda, a possibilidade de exploração de áreas que não necessariamente possuam características históricas, caso do South Street Seaport, em Nova York, cuja conversão em área de comércio e lazer foi baseada na replicação dos fragmentos de autenticidade remanescentes no local.

O shopping center, com seus corredores labirínticos, possui como essência a mimese da cidade, substituindo a experiência urbana, recriando a cidade como espaço comercial. Lojas de rua, com as de Rodeo Drive, em Beverly Hills, vêm usando a história, real ou inventada, como marketing. Evidentemente, o shopping, mais cedo ou mais tarde, seria unido ao parque temático. Huxtable relata a primeira experiência desta confluência, o West Edmonton Mall, no Canadá, cuja propaganda é de que o mundo inteiro está presente dentro do shopping. O empreendimento conta com áreas temáticas de referências diversas distribuídas por lojas, parques, restaurantes, salas de cinema e até uma capela. Logo após, foi inaugurado em Minessota, nos Estados Unidos o Mall of America, ainda maior e mais impressionante, incluindo, além dos espaços de lazer, edifícios de escritórios e universidade, entre outros. Huxtable enxerga nesta transposição da cidade para o shopping center a perda da diversidade e opções de escolha que, antes presentes no espaço urbano, são eliminadas no novo ambiente controlado. Podemos observar que, igualmente no Brasil, encontramos a inserção de programas voltados para a oferta de serviços nos shoppings, principalmente com a incorporação de edifícios comerciais anexos, mas também universidades e temas, caso do Barra World Shopping, no Rio de Janeiro, com áreas que reme60. Ver capítulo 5.1 tem a Veneza, Londres, Paris e outros destinos turísticos. ${ }^{60}$

Huxtable se pergunta, então, como a arquitetura fun- 
61. ORVELL, Miles. The Real Thing: Imitation and Authenticity in American Culture, 1880 - 1940. In. HUXTABLE (1993) pp.110-111.

ciona sob esta ótica da diluição entre imitação e autenticidade, e conclui que se torna um fenômeno cada vez mais econômico e menos estético. Para a autora, a indistinção entre real e cópia é, com toda sua perversidade, um fenômeno fascinante. Cita Miles Orvell ${ }^{61}$ e sua afirmativa de que somente no século XX a autenticidade foi considerada elemento essencial à arte, em resposta ao ecletismo produzido pela máquina durante o século anterior. Esta busca pelo autêntico teria sido a base do modernismo, mas o inevitável desejo pela réplica de baixo custo e fácil obtenção prevaleceu com mais força.

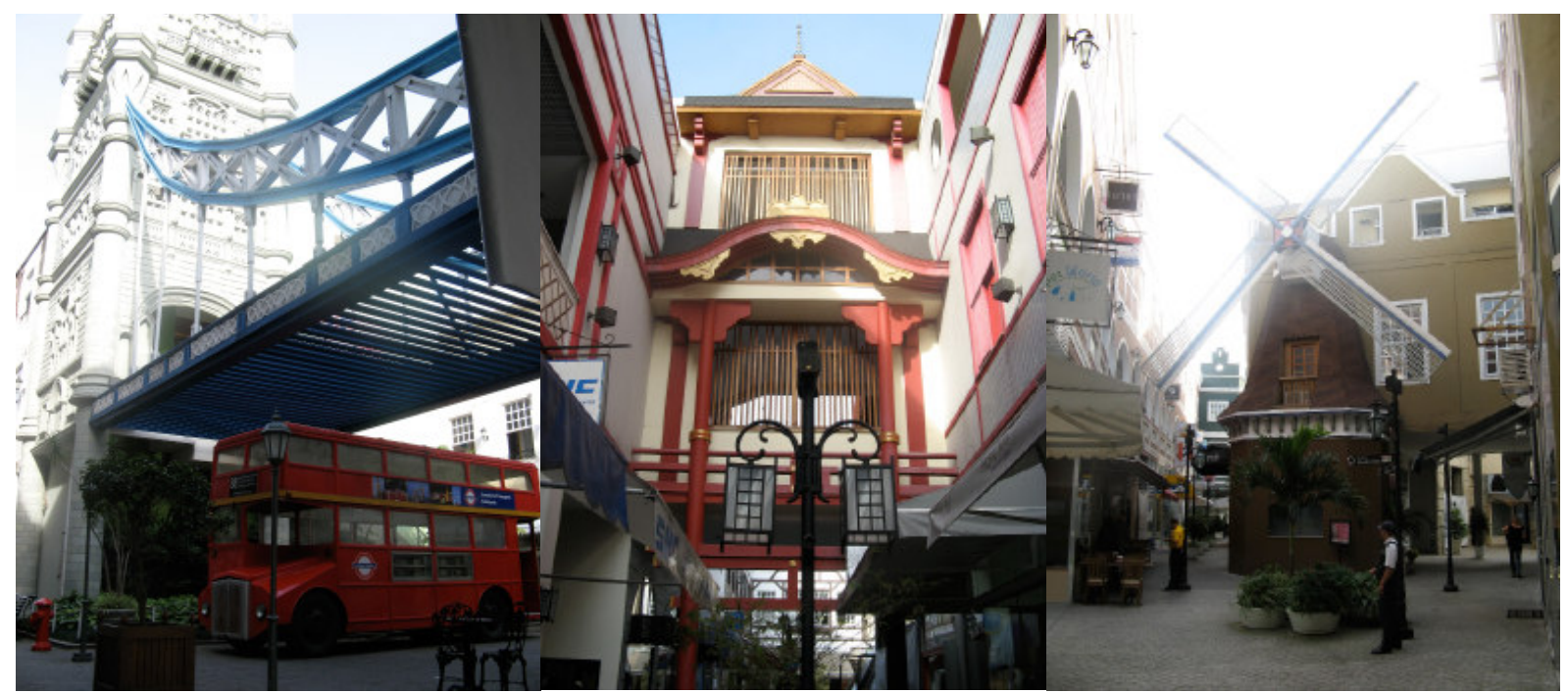

Figs 58, 59 e 60. Inglaterra, Japão e Holanda, no Barra World; Rio de Janeiro.

O pós-modernismo pode ter sido uma vingança para aqueles que resistiram a estética e moral modernistas, mas não possui vocabulário de fácil apreensão. Huxtable afirma que o público, satisfeito com a simulação, deixa de se importar 62. HUXTABLE (1993) p.112. com aquilo que chama "arquitetura real" ${ }^{62}$. Assim, o reconhecimento da paisagem pop permitiu que muitos arquitetos passassem a trabalhar a serviço da fantasia.

Recentemente, o grupo Disney recrutou um time de arquitetos consagrados, como Frank Gehry, para projetar uma série de edifícios administrativos e anexos aos parques. No entanto, a maioria deles evitou referências diretas aos personagens infantis, fugindo da característica da arquitetura temática de fornecer informações de apreendimento imediato. Procuraram, ainda, incluir elementos que caracterizassem o projeto como sendo de sua autoria, o que não costuma ocorrer em espaços temáticos. Nestes locais, normalmente, não trans- 
parece a assinatura do artista responsável, uma vez que devem prevalecer elementos relacionados ao tema. Além disso, a incursão destes profissionais na arquitetura temática se deu em projetos encomendados por uma instituição já consolidada, financeiramente bem sucedida. Possivelmente, a parceria não seria viável se a proposta partisse de qualquer outra empresa atuante no campo do entretenimento temático que não o grupo Disney. Huxtable questiona se não é perigoso que arquitetos baseiem suas linguagens e mensagens no que Umberto

63. Idem p.113. Eco chamou "cultura contaminada"63. A autora, entretanto, se diz partidária dos que vêem a cultura popular como fonte de aprendizado e não negam as realidades e necessidades de seu tempo, incluindo o shopping, o subúrbio e a rua comercial.

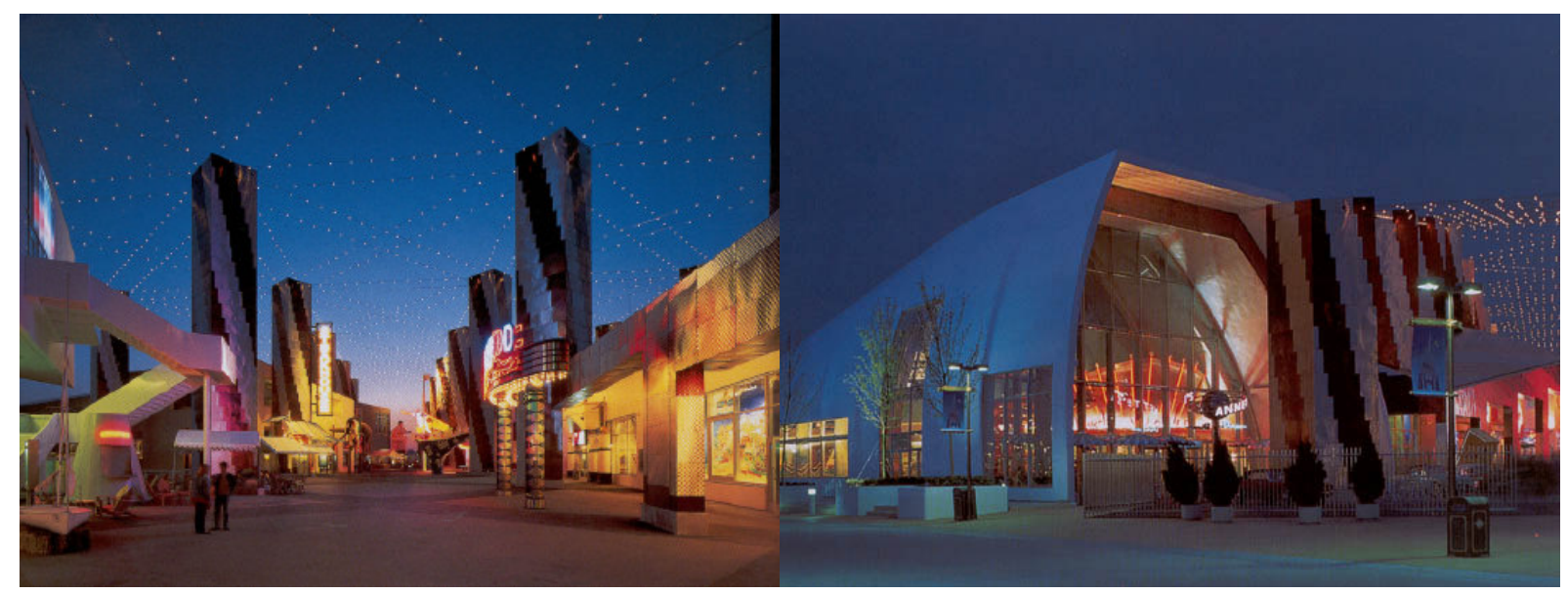

Figs 61 e 62. Disney Village, projeto de Frank Gehry; Marne-la-Vallée, França.

Finalmente, mostra como a ilusão presente no temático aparece na arquitetura contemporânea, no sentido de que, hoje, qualquer arquitetura produzida depende de inovação e extravagância como pontos focais, ainda que extremamente bem planejada. Um exemplo seriam os edifícios de Frank Gehry, em que as formas grandiosas podem parecer alheatórias e de extravagância gratuita, quando são cuidadosamente 64. Ver capitulo 5.2 pensadas. ${ }^{64}$ Conclui que a palavra 'artificial' pode ter perdido significância, mas a arquitetura ainda é a arte responsável pelo desenho de nossas cidades.

Conceitos ral necessário para qualificar com exatidão a arquitetura concontemporâneos temporânea. Hoje coexistem autores e correntes variadas, em geral avaliando o momento presente em relação ao moderno 
65.HARVEY (1999) ou pós-moderno. David Harvey ${ }^{65}$ afirma ser o moderno uma 66. MONTANER (2001) condição para o pós-moderno, Montaner ${ }^{66}$ avalia que a mo-

67. EISENMAN, Peter. $O$ pós funcionalismo. In NESBITT (2006) pp. $97-101$

68. MONTANER (2002) templa o pluralismo. ${ }^{68}$

O período de crescimento da chamada cultura pop caracterizou-se pela confluência entre as culturas erudita e popular, configurando um momento de complexidades e sobreposições. Para explicitar esta distinção entre culturas, podemos recorrer ao conceito de Campo de Produção, definindo 69. BOURDIEU (2001) pp.100-154 por Bourdieu ${ }^{69}$. O Campo de Produção é entendido como derivado da oposição entre duas vertentes, o Campo de Produção Erudita, em que as normas e critérios de avaliação são produzidos internamente, por aqueles que são simultaneamente clientes e concorrentes, e o Campo da Indústria Cultural, que produz para o grande público. Por produzir para os próprios produtores, o Campo de Produção Erudita rompe com as outras categorias, ou seja, com os não intelectuais, enquanto o Campo da Indústria Cultural opera segundo a lei da concorrência para conquistar o maior mercado possível.

No Campo de Produção Erudita, a crítica (em sua maioria produtores) atribui a si própria a tarefa de fornecer uma interpretação criativa para uso dos criadores, como forma de justificar a obra. Fica estabelecida, então, uma relação de solidariedade entre crítica e autores. A crítica se coloca a 


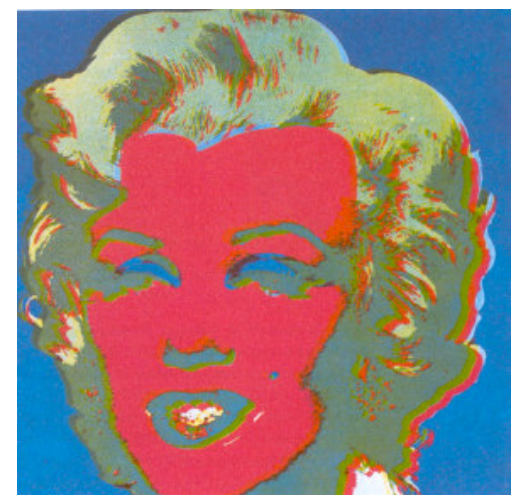

Fig 63. Andy Warhol: Marilyn Monroe (1964).

70. MORIN, Edgar. Introduction à la Pensée Complexe. In. MONTANER, (2002) p. 118 serviço do artista com a função de dar inteligibilidade à obra e, em contrapartida, valoriza a si própria. O sucesso estrondoso assusta a crítica, por ser conseqüência da manifestação do grande público, afinal a distância entre o sucesso de público e o reconhecimento no interior do grupo pode ser indicador de autonomia do campo.

Nada mais emblemático para exemplificar a inserção da cultura popular no meio erudito que a pop art de Andy Warhol. Em suas obras repletas de ambigüidade e ironia, Warhol reproduzia ícones da cultura de massa, sempre remetendo às técnicas adotadas pela publicidade. Se, por um lado, o trabalho criticava o sistema, por outro o fortalecia, mitificando e elevando à arte objetos de consumo imediato. Montaner acredita que, ao quebrar a barreira entre o popular e o erudito, a cultura pop fundamentou a base para a cultura contemporânea.

Diante desta configuração cultural contemporânea complexa, Montaner cita Edgar Morin, principal responsável pela fundamentação do pensamento complexo e do próprio conceito de complexidade. Segundo Morin ${ }^{70}$, "o pensamento complexo aspira o pluridimensional", em oposição ao recorte metonímico proposto pelo pensamento cartesiano. Segundo esta nova visão, o pensamento científico linear foi paulatinamente substituído pelo pensamento em redes, segundo o qual o objeto de estudo deve ser considerado dentro de sistemas, jamais isoladamente.

Conforme vimos, os conceitos de complexidade e contradição foram aplicados à crítica arquitetônica por Robert Venturi, dando início a questionamentos fundamentais sobre 71. Ver capitulo 1.3 a então predominante estética moderna. ${ }^{71}$ Venturi analisa a arquitetura seguindo a idéia de complexidade, de que já não é possível olhar as partes isoladamente, somente podem ser analisadas as relações estabelecidas entre os diversos componentes de um sistema.

Montaner afirma que, além de recorrer à complexidade, a arquitetura do período dominado pela cultura pop tem como ponto comum a referência a imagens históricas como instrumento de comunicação. Como vimos na análise de "Learning from Las Vegas", trata-se de uma arquitetura em que a 
comunicação sobrepõe-se à edificação e, para comunicar, esta arquitetura faz uso de referências previamente conhecidas. Montaner exemplifica com a Piazza d'Italia, em New Orleans, um projeto de Charles Moore que consiste em um compêndio de formas históricas recontextualizadas, acrescidas de um repertório pop, com luzes neon. Cita, ainda, a obra de Michael Graves, mais tarde responsável por vários projetos para a Walt Disney Company, entre eles os polêmicos hotéis Swan e 72. Ver capitulo 5.2 Dolphin. $^{72}$ Projetados em conjunto, os hotéis inauguraram um novo modelo arquitetônico para a empresa, prescindindo das referências aos personagens consagrados no cinema. No entanto, o modelo temático não foi abandonado, já que o projeto reportava a figuras mitológicas - cisne e golfinho -, presentes em contos de fadas e, conseqüentemente, no imaginário infantil. Graves afirma ter buscado inspiração nos 73. DUNLOP (1996) pp.63-74. jardins e fontes barrocos e na arquitetura de Bernini. ${ }^{73}$

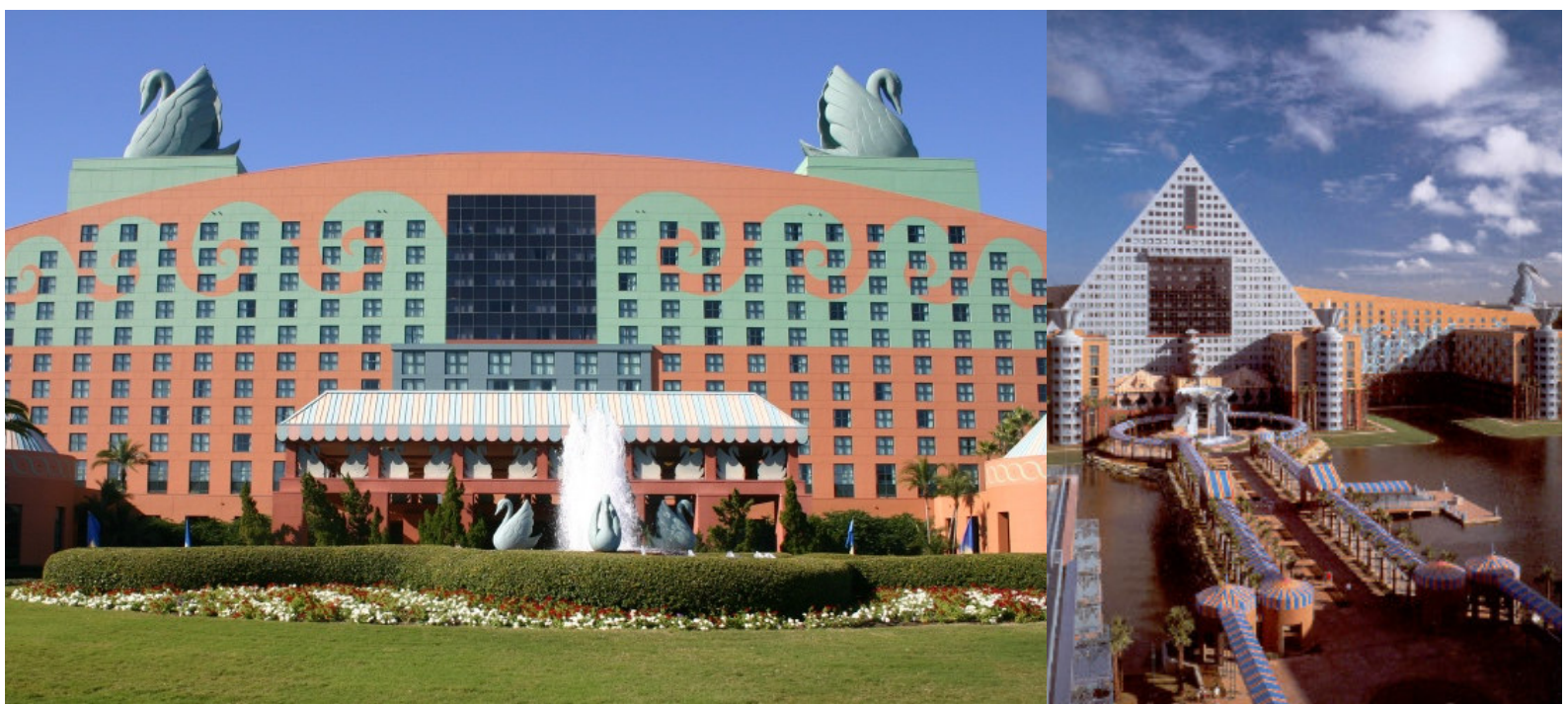

Figs 64 e 65. Hotéis Swan e Dolphin.

Montaner, então, cita explicitamente os centros temáticos e complexos de lazer a que nos referimos aqui, quando afirma que

"Esta maneira de fazer, ensaiada nas experiências pós-modernistas dos anos setenta e oitenta, converteu-se na mais eficaz para os conjuntos temáticos e para as promoções imobiliárias das empresas de diversão e comunicação. Bairros residenciais fechados, hotéis, cassinos, shoppings centers, parques temáticos, centros esportivos e todo tipo de arqui- 
74. MONTANER (2001) p.128.

tetura do consumo adotaram as imagens do espetáculo - o cinema, o esporte e a moda como fonte de inspiração para suas formas" ${ }^{74}$

Realmente, esta linguagem arquitetônica nostálgica e irônica reflete a sociedade de consumo contemporânea, ambígua e complexa.

Montaner estabelece, ainda, uma associação entre a arquitetura contemporânea e a cultura do fragmento, relacionando a realidade atual, fragmentária, à teoria da complexidade. Para ele, há antecedentes históricos para a cultura do fragmento, especialmente na pintura, mas, também na arquitetura, caso da já citada Vila Adriana, composição de formas previamente conhecidas recontextualizadas. Identifica, então, dois mecanismos segundo os quais funciona a cultura do fragmento - colagem e montagem. No primeiro caso, há uma sobreposição de peças que configuram um novo conjunto. Trata-se, portanto de um conceito antigo que remonta ao kitsch, ao pitoresco. Entretanto, poderíamos pensar que o temático está igualmente relacionado à colagem, pois, ao pretender a unidade do projeto em torno do tema, configura-se uma sobreposição de referências de forte caráter simbólico recombi75. Ver capitulo 5.2 nadas. $^{75}$

Já a montagem recorre à seqüência narrativa cinematográfica. Profissionais como Rem Koolhaas levam para a arquitetura a proposta do cinema de articular planos de significado, que contam toda a história em menos de duas horas. A própria Disneyland é resultado assumido de uma transposição da linguagem cinematográfica para o espaço físico tridimensional. Walt Disney concebeu seu primeiro parque temático baseado no objetivo de fazer a narrativa ultrapassar as duas dimensões da tela. ${ }^{76}$ Os Espaços Temáticos trouxeram a cenografia até o p.11. público. Neles, o visitante literalmente entra na história, torna-se personagem da história. Em inúmeros estabelecimentos, o percurso é pensado como uma narrativa cinematográfica, em que as visões se sucedem de forma planejada para compor a história.

Pode-se traçar uma analogia, considerando que nos ambientes temáticos a câmera é substituída pela visão de quem percorre os espaços, de modo que, tal qual em um cenário, 
recebem tratamento especial as áreas que podem ser vistas. Evidentemente, neste caso a região em quadro aumenta consideravelmente; agora, o espaço disponível para a narrativa já não está restrito à tela, ampliando a quantidade de informação necessária para envolver o visitante na fantasia. Em alguns Espaços Temáticos, apenas os setores voltados para serviços internos e manutenção não fazem referência ao tema. Muitas atrações de parques temáticos não foram pensadas para serem vistas de cima e, portanto, não recebem tratamento cenográfico em suas coberturas. Assim, um passeio no teleférico em Disneyland pode revelar a unidade dos galpões mascarados em diversas atrações independentes, por exemplo.

O nível de detalhes normalmente apresentado nos Espaços Temáticos de certa forma remete ao posicionamento e aproximação de câmera cinematográficos. Os ambientes são pensados para serem vistos primeiro em um plano geral. Conforme se dá a aproximação do visitante, é possível perceber um nível crescente de detalhamento em uma espécie de closeup. Então, o visitante é atraído inicialmente pelo conjunto, até que algum ponto em especial atraia sua atenção. Ao se direcionar para este foco, passa a perceber elementos novos. Com isso, é criada a expectativa de que há sempre algo a ser visto em seguida, um detalhe que a alguma distância havia passado

77. Idem p.158. desapercebido. ${ }^{77}$ Portanto, os Espaços Temáticos são essencialmente fragmentários, por operarem tanto como colagens quanto como montagens.

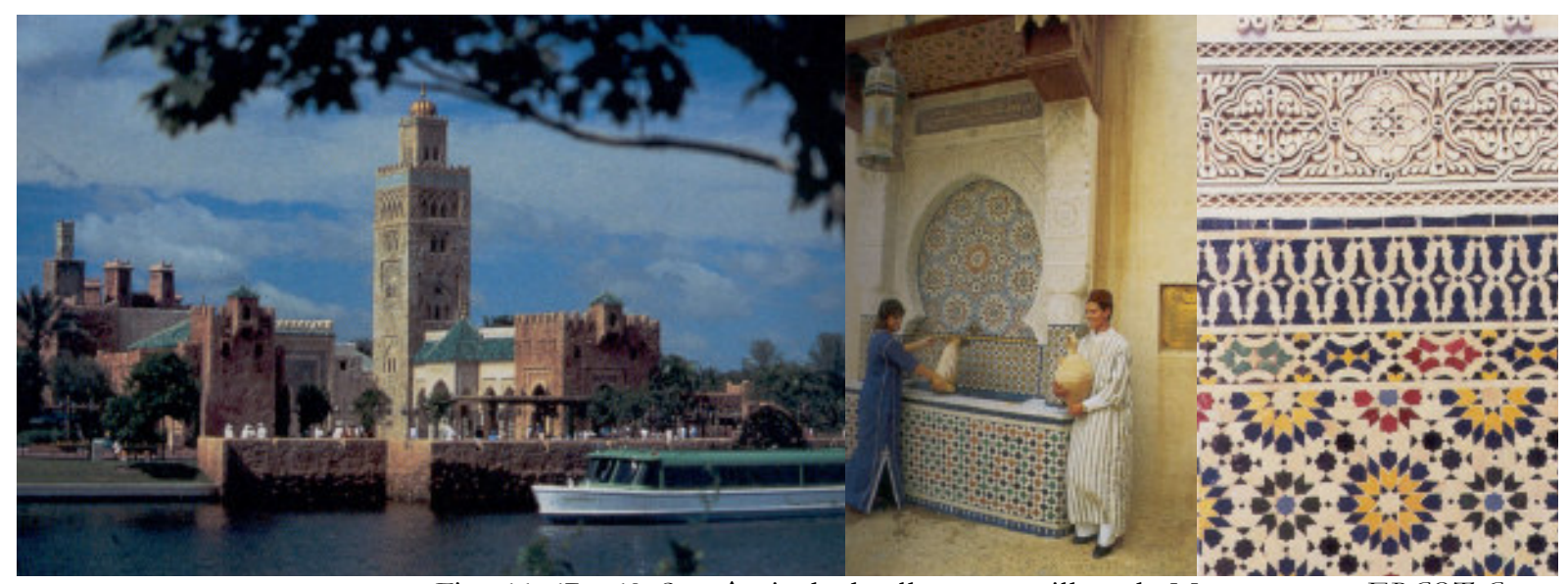

Figs 66, 67 e 68. Seqüência de detalhes no pavilhão do Marrocos, em EPCOT Center.

A inserção do modelo temático no contexto pós-moderno pode ser discutida recorrendo às direções tomadas pela 
78. COLQUHOUN (2004) p.225.

79. JAMESON, Fredric. Postmodernism, or the cultural logic of the late capitalism. In. FJELLMAN (1992) sentada, em detrimento ao que seria visto na realidade. Conforme disse Umberto Eco, "A imaginação americana demanda 80. ECO (1986) p.8. o real e, para obtê-lo, precisa fabricar o totalmente falso" ${ }^{\text {, }}$, característica que podemos, cada vez mais, estender aos povos de influência norte-americana de modo geral. Até aqui vimos que grande parte dos críticos avalia Entre as diferentes soluções de apropriação das formas clássicas utilizadas literalmente, encontra-se a caricatura, da qual podemos aproximar os Espaços Temáticos. No entanto, segundo ele,

“(...) por mais diferentes que essas soluções possam ser, elas possuem uma coisa em comum - todas rejeitam a proibição modernista à imitação. Todas, até certo ponto, afrouxam a ligação que o pensamento historicista estabe-

Podemos enxergar o temático como um fenômeno que extrapola essa tendência, uma vez que não somente aceita a imitação, mas faz dela seu fundamento primordial. Se uma tendência pós-moderna é dissociar a forma artística de sua época e contexto, no temático a idéia é trazer para o momento atual, através da imitação, esta espécie de "espírito de época", enunciado por Hegel. A distinção reside, evidentemente, no fato de que, paradoxalmente, se busca o "espírito" de uma outra época, retomada através da recontextualização de seu repertório arquitetônico.

O repertório clássico é, portanto, apropriado pelo temático, assim como referências de outras épocas, em uma tentativa escapista de transferência para uma situação distante do cotidiano, seja ela essencialmente fantástica ou retorno à determinada época/cultura. Trata-se de um local cujos detalhes devem, em sua totalidade, receber tratamento remetendo ao tema adotado, para que o freqüentador o considere verossímil, sem jamais lembrar-se da realidade externa a este ambiente. Esta idéia está diretamente relacionada ao conceito platônico de simulacro - "a cópia idêntica para um original que nunca existiu"79 - uma vez que estes locais se convertem em suporte para uma arquitetura e/ou design simbólicos, que apresentam aquilo que o espectador esperaria ver na época/cultura repre- 
a cultura contemporânea em relação à sua antecessora, para 81. LIPOVETSKY (2004) a maioria o pós-modernismo. Entretanto, Gilles Lipovetsky ${ }^{81}$ extrapola esta fronteira, ao afirmar que a pós-modernidade sequer existiu. Para corroborar esta tese, Lipovetsky trabalha com o conceito de "hipermodernidade" que, mais do que propor uma mudança retórica, traz inovações semânticas de validade incontestável. Ele entende que a emergência do conceito de pós-modernidade coincidiu com o crescimento de uma sociedade individualista, consumista e plural, preocupada com o presente imediato. Entretanto, Lipovetsky salienta que a idéia de pós-modernidade carrega consigo uma idéia de extinção do contexto moderno incoerente, já que seria mais adequado pensarmos que vivemos um momento de superlativa modernidade, não de superação. Assim, o contexto contemporâneo seria caracterizado pelos "hiper", em que, muitas vezes paradoxalmente, tudo é levado às últimas conseqüências.

Após estabelecer que o "hipermoderno" extrapola a valorização do presente, Lipovetsky questiona, então, o que acontece com a relação estabelecida com o passado e o futuro. Neste sentido, retoma a discussão sobre a exploração consumista da memória em que tudo passa a ser passível de classificação como patrimônio histórico. O fenômeno, chamado de "hipermemória", marca a substituição do caráter simbólico do monumento por sua faceta midiática, com a criação de museus dedicados aos mais diversos tópicos, acréscimo de shows a 82. Ver capitulo 3.3 sítios históricos e venda de souvenirs. ${ }^{82}$

Percebemos, portanto, que, ainda que a literatura específica sobre as implicações da chamada Arquitetura Temática seja bastante recente e escassa, encontramos na crítica sobre este modelo reflexos de inúmeras críticas prévias. Tais críticas anteriores trataram sobre a pertinência e importância do ornamento na arquitetura ao longo do tempo, podendo ajudar a compreender a arquitetura de hoje, além de mostrar que esta discussão aparentemente recente há muito permeia a crítica arquitetônica. Associando a literatura acerca do ornamento à crítica sobre a sociedade contemporânea, buscamos estabelecer os fundamentos para avaliar e qualificar o papel do modelo temático na arquitetura atual e, conseqüentemente, na construção de identidades locais. 


\section{Capítulo 2 Entendendo o Temático}

\begin{abstract}
"Malls have become much more than just places to shop. They have become places for people to visit as centers of community life. At the same time, entertainment parks have long recognized a need to provide more than just rides and entertainment. Therefore the juxtaposition and integration of retail and entertainment have become inevitable. We shall see more and more of such successful fusion throughout the next decade and into the $21 \mathrm{st}$ century."1
\end{abstract}

Terry Van Gorder, presidente e CEO do Knott's Berry Farm

\section{Introdução}

1. Sobre a inclusão do parque no Mall of America. In Stores, August 1989, 43-44. In ROGERS, GAMANS e GRASSI (1991). pp.278-

279.

"Shoppings se tornaram bem mais que locais para comprar. Tornaram-se lugares para as pessoas visitarem, centros da vida da comunidade. Ao mesmo tempo, os parques de diversão há muito reconheceram a necessidade de oferecer mais que apenas rides e diversão. Portanto, a justaposição e integração de venda e lazer tornou-se inevitável. Devemos ver mais e mais desta fusão de sucesso ao longo da próxima década e do sécullo XXI."

Para entender o conceito de Cidade Temática retomaremos a idéia de Espaço Temático, estruturada na dissertação de mestrado "Design, cenografia e entretenimento - uma análise da evolução dos Espaços Temáticos", defendida em abril de 2004, pelo departamento de Artes e Design da Pontifícia Universidade Católica do Rio de Janeiro. A discussão sobre Cidades Temáticas tem início questionando os limites que as definem, a partir das principais características que tornam pertinente classificar e estudar um local como temático. Este capítulo inicia, portanto, a definição do objeto de estudo, deixando clara a definição de Arquitetura Temática a ser adotada, e mostrando como este modelo surgiu e se desenvolveu. Conforme veremos, uma série de especificidades na aplicação do tema difere estes espaços, aqui chamados temáticos, de outros em que é igualmente evocado um certo caráter espetacular.

Em seguida, trataremos das chamadas Cidades Temáticas, procurando mostrar como o modelo temático transcendeu os estabelecimentos comerciais e passou a ser usado como elemento de construção de identidades locais e instrumento para o marketing das cidades, visando uma ampliação de seu potencial turístico.

2.1 Certamente o termo 'temático' nos remete de imediato aos grandes parques, a ponto de associarmos freqüentemente as duas palavras; não se pode falar em temático sem que 


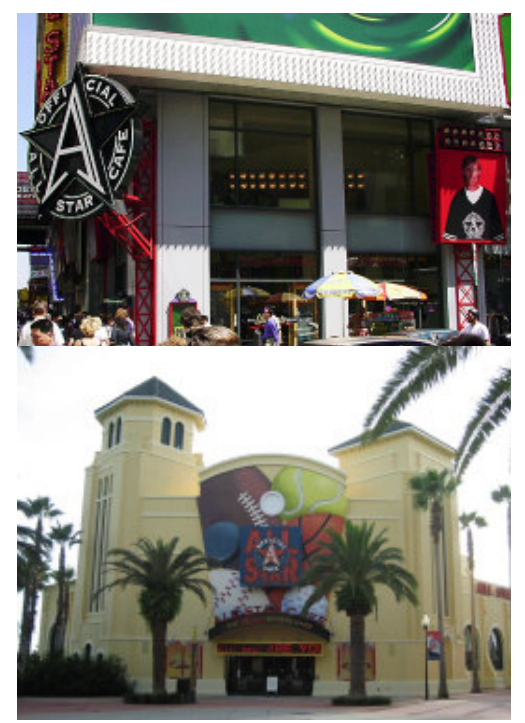

Figs 1 e 2. All Star Cafe em Nova York e em Walt Disney World.

2. A cadeia de restaurantes $A l l$ Star Cafe tinha como parceiros os atletas Wayne Gretzky, Joe Montana,

Shaquille O’Neal, Ken Griffey, Jr., Andre Agassi e Monica Seles. Toda a concepção do espaço remetia ao tema 'esporte'. A última filial ainda aberta, dentro do Walt Disney World Resort foi fechada em 2008.

imediatamente seja evocado o parque. A idéia de algo 'temático’ está de tal forma impregnada da imagem de Mickey Mouse que pode nos levar a crer que apenas parques podem receber tal adjetivo. Ainda que os parques temáticos tenham inegável pioneirismo na difusão do uso de temas e sejam citados aqui como referência, o tema é hoje aplicado em situações cada vez mais diversas. A opção pelo termo Espaços Temáticos definindo um espaço, parque ou não, concebido de acordo com uma temática pré-estabelecida, destaca esta diferença.

Para compreender os Espaços Temáticos, é preciso primeiramente entender que o tema não precisa estar associado ao programa arquitetônico, muito pelo contrário. Um ginásio esportivo não é considerado um Espaço Temático sobre esportes, apenas recebe a função de abrigá-los. Por outro lado, em um espaço baseado no tema 'esporte', como a cadeia de restaurantes All Star Cafe $e^{2}$, por exemplo, o projeto é inspirado no tema esportivo, bem como na imagem de atletas famosos que possuem sociedade no estabelecimento. Entretanto, sua função não está relacionada à prática esportiva, o local acumula as funções de bar, boite e loja.

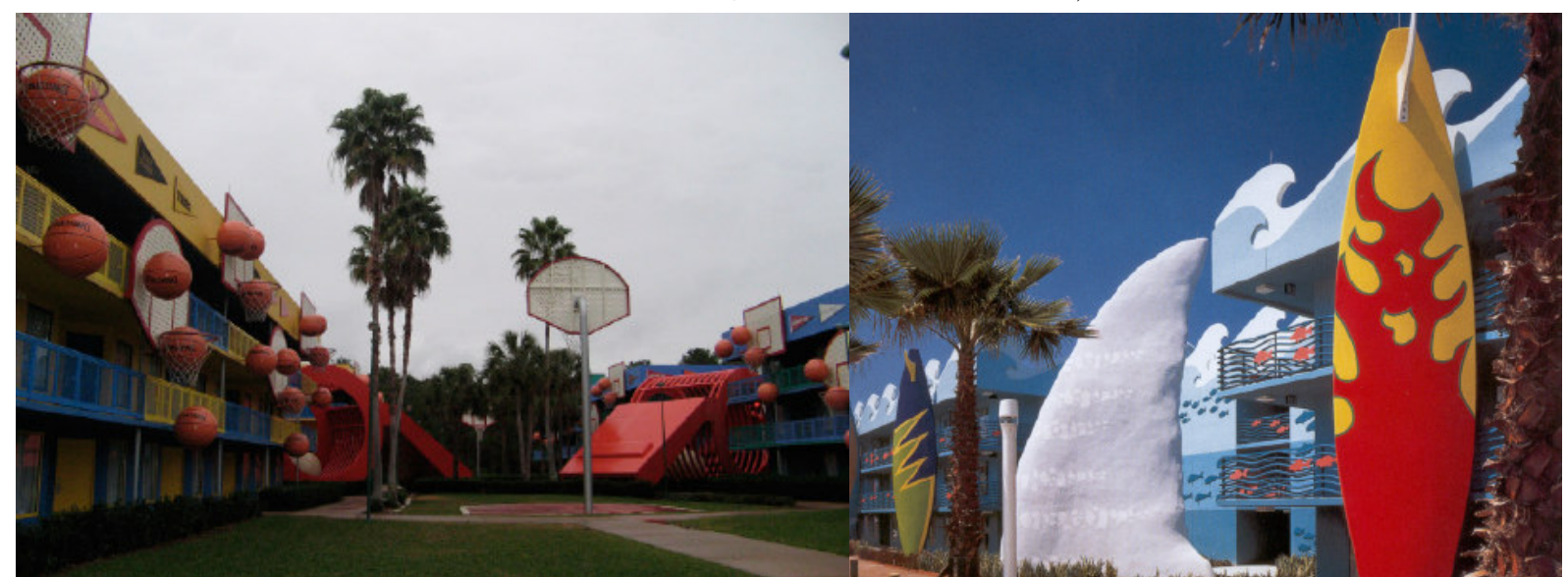

Figs 3 e 4. Hotel All Star Sports em Walt Disney World.

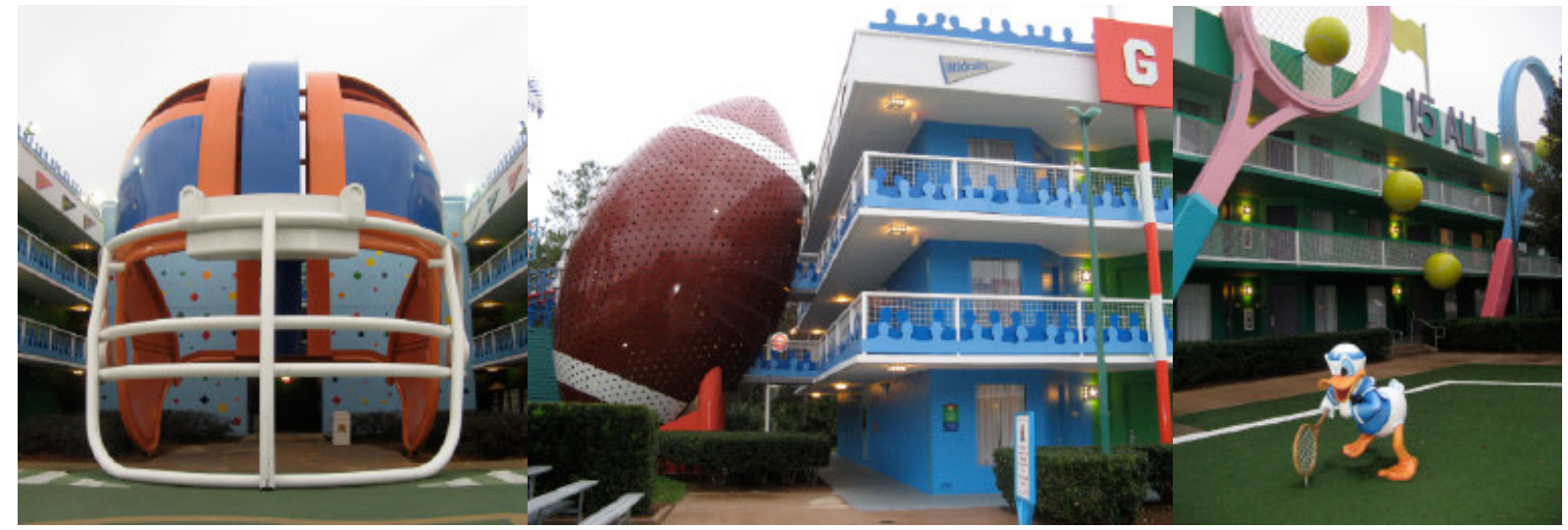

Figs 5, 6 e 7. Hotel All Star Sports em Walt Disney World. 
3. http://www.cite-musique.fr

4. http://www.hardrock.com

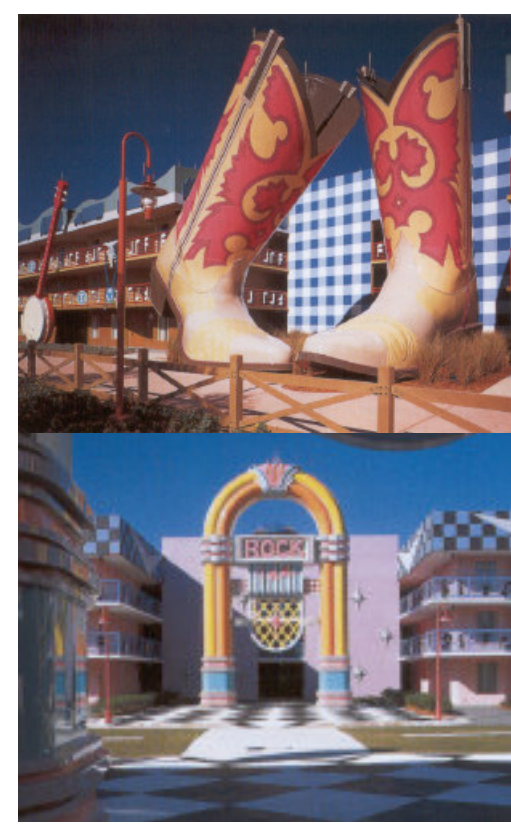

Figs 8 e 9. Hotel All Star Music em Walt Disney World.
Analogia semelhante pode ser feita entre a Cité de la Musique e bares como os da cadeia Hard Rock Cafe. Localizado em Paris, no Parc de La Villete, e projetado pelo arquiteto Christian de Portzamparc, o primeiro é um espaço voltado para a música em todos os seus aspectos. O conjunto inclui salas de concerto, escola de música, biblioteca, etc, em uma composição, segundo o arquiteto, inspirada no ritmo musical. ${ }^{3}$ Entretanto, o projeto não apresenta as referências diretas e figurativas, que caracterizam os Espaços Temáticos.

No exemplo dos bares Hard Rock Cafe, como em outros Espaços Temáticos que exploram o tema 'música', a associação transparece com menor sutileza. Ao invés de referências como ritmo, encontra-se o uso de ícones musicais como guitarras gigantescas pendendo do teto ou decorando a fachada, carros típicos do período de apogeu do Rock n’Roll também pendentes ou rasgando as fachadas, além de relíquias antes pertencentes a ídolos pop - figurinos, instrumentos, prêmios, fotos, autógrafos, etc - decorando as paredes. ${ }^{4}$ Ao contrário da Cité de la Musique, nos bares, a temática musical é explorada através de ícones de fácil reconhecimento recontextualizados e apresentados sob uma ótica alegórica. O mesmo acontece com alguns novos hotéis do complexo Disney World, baseados em temas como música e esportes. Concluímos que a função e o programa da edificação não estão necessariamente relacionados ao tema.

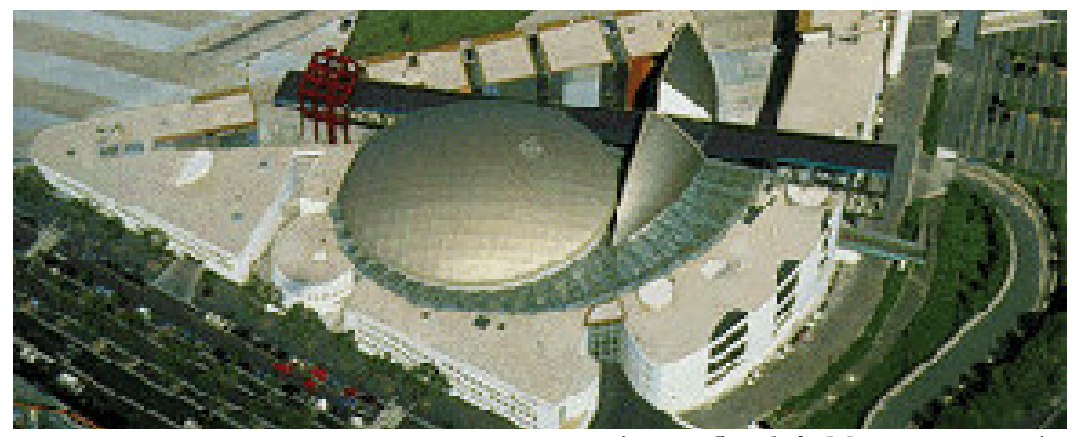

Fig 10. Cité de la Musique, em Paris.

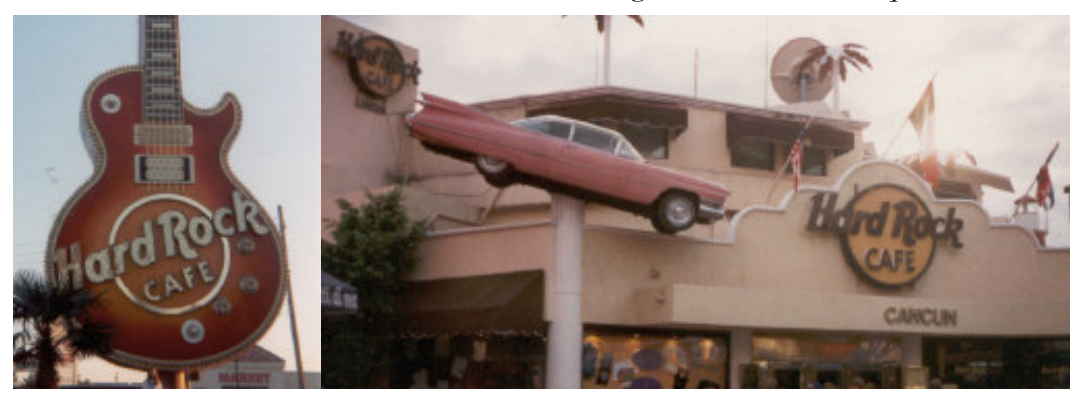

Figs 11 e 12. Hard Rock Cafe, em Las vegas e Cancun. 
É importante, ainda, diferenciar os Espaços Temáticos daqueles em que apenas ocorre uma reprodução de estilos arquitetônicos. Nos Espaços Temáticos os temas e elementos referentes ao partido são descontextualizados para que se adeqüem aos objetivos do estabelecimento, para que o visitante identifique rapidamente o tema apresentado. Portanto, mesmo nos casos em que o tema é um local ou uma cultura - um bar mexicano, por exemplo - é apresentada não uma reprodução de espaços existentes na cultura inspiradora, mas a visão que se tem desta cultura. O espaço refletirá a imagem construída pela indústria cultural a respeito do assunto inspirador. Nessa concepção não são tidos como Espaços Temáticos prédios de inspiração neoclássica, construídos no Rio de Janeiro, por exemplo.

No entanto, deve se esclarecer o fato de que, se por um lado, o simples uso de um estilo arquitetônico não é considerado tema, por outro o Espaço Temático pode aproveitar-se do estilo para compor a narrativa e ambientação que identificam o tema. Um edifício neoclássico como o capitólio de Washington não é um prédio temático, ainda que possa ser analisado, sob diversos aspectos, como antecessor do modelo 5. Ver Capítulo 3.1 temático atual. ${ }^{5}$ Porém, o mesmo estilo colonial norte americano pôde ser descontextualizado e recontextualizado ao ser aplicado ao prédio que abriga a atração The American Adventure em Epcot Center. A atração está situada em uma área do parque que evoca as grandes feiras e exposições universais, pois cada um de seus pavilhões representa um país. Para representar os Estados Unidos foi eleito o mesmo estilo encontrado nas construções clássicas do período de pós-colonização que caracterizou o processo de independência e democratização norte-americana. Este estilo era largamente utilizado por Thomas Jefferson no momento da assinatura da constituição do país e evoca uma época que representa, para os americanos, sua unidade e identidade. Assim, como a história, os estilos artísticos e arquitetônicos são apropriados pelo entretenimento temático, seja para identificar uma época ou local, seja para estabelecer um vínculo entre o espaço temático e características do estilo exposto. Porém, no Temático, estes estilos são apresentados, invariavelmente, de forma descontextualizada. 


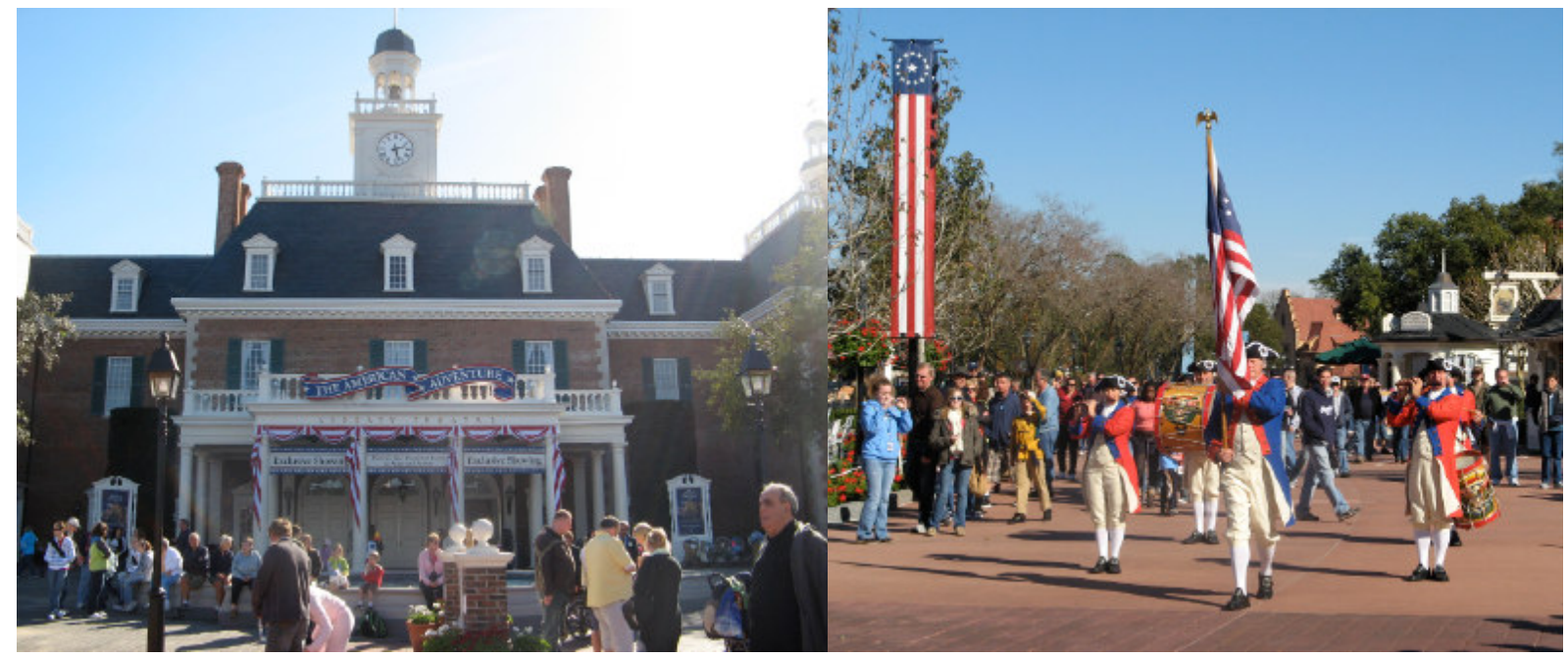

Figs 13 e 14. The Americam Adventure, em EPCOT Center.

Apropriações de estilos, como a ocorrida em Washington, ou no Rio de Janeiro no início do século XIX, explorando o neoclássico francês, carregam consigo um certo caráter

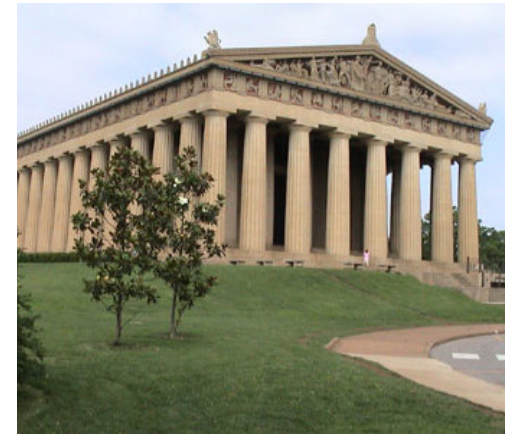

Fig 15. Parthenon, em Nashville. espetacular, por objetivarem a aquisição de valor em função da associação com a imagem evocada pelo estilo utilizado, mas não podem ser consideradas temáticas. $\mathrm{O}$ mesmo pode se dizer do Parthenon de Nashville, erguido na cidade norteamericana de mesmo nome em comemoração a seu centenário, em 1897. Trata-se de uma réplica em tamanho natural do famoso templo construído em Atenas durante o período antigo clássico. Certamente, manifestações como estas contribuíram para a construção do modelo temático. Entretanto, nos casos apresentados ainda não há de maneira explícita o aspecto comercial, a alegoria, a conjunção de símbolos diversos em um mesmo edifício para criar o Espaço Temático, e sim uma reprodução de estilos ou construções existentes.

A Estátua da Liberdade, por exemplo, ainda que convertida em símbolo kitsch, nunca foi considerada manifestação temática. No entanto, ao ser reproduzida como ícone em novos contextos objetivando a associação com o tema New York, a réplica da estátua vem sendo convertida em elemento de construção do Espaço Temático em mais de uma situação. No Rio de Janeiro, o shopping New York City Center, cuja temática se inspira na cidade de Nova York, fez da reprodução da estátua sua grande marca, localizando-a em sua entrada e vestindo-a de acordo com a época do ano - de Papai Noel, durante as Festas Natalinas ou com o uniforme da seleção brasileira de 

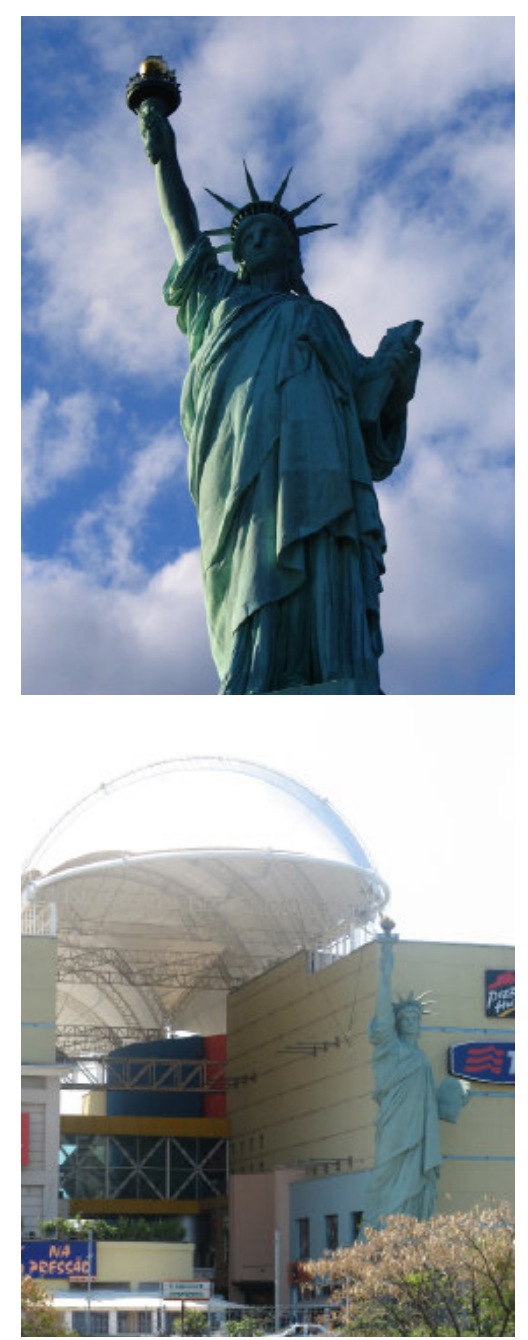

Figs 16 e 17. Estátua da liberdade original e réplica no New York City Center.

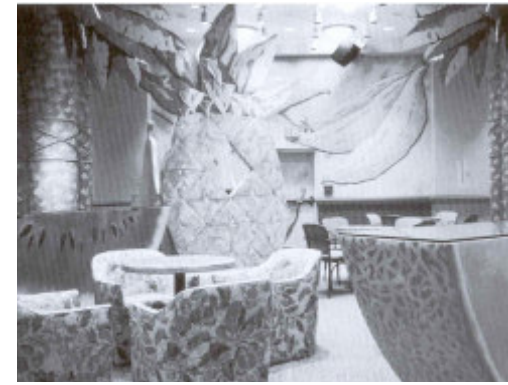

Fig 18. Copacabana Lounge, no Hotel Swan, de Michael Graves, em Walt Disney World. Clichés para representar o Brasil. futebol durante a Copa do Mundo, por exemplo. Já em Las Vegas a estátua foi reproduzida no hotel-cassino New York New York, cuja arquitetura faz uma colagem de edifícios característicos de Nova York entremeados por um trilho de montanha russa. Assim, embora seja definido por uma linha tênue, há um limite entre programa - determinado pela função a que se destina a edificação - partido - a opção estética adotada no projeto - e tema - a narrativa a ser contada. Evidentemente há casos em que estes elementos são sobrepostos. O próprio Hard Rock Cafe tem a musica tanto como tema quanto como programa - além de bar, suas filiais costumam incluir palcos para shows.

Os Espaços Temáticos propõem-se, portanto, a fazer com que o visitante se transporte para o local, ou mesmo para o tema representado. Mais que isso, um Espaço Temático pretende ser identificado como representação do que está no imaginário coletivo a respeito do tema, não como réplica de seu inspirador. Para atingir este objetivo, o projeto é baseado em ícones identificados com o assunto retratado, pouco importa se são ou não condizentes com a realidade. Conseqüentemente, o espaço final nunca existiu até ser concretizado através da Arquitetura Temática, ou seja, um espaço cujo tema é o Brasil, por exemplo, será totalmente distinto de qualquer local que exista no país, porém englobará referências que proporcionem o entendimento, que sejam comumente associadas ao país. Assim, o tema é desenhado utilizando os símbolos que imediatamente afloram quando se pensa no tema, mesmo que sejam fantasiosos, mitológicos.

Não se pode falar em “estilo temático", pois se trata de um fenômeno cuja manifestação formal varia de acordo com o tema a ser explorado. A aproximação entre os Espaços Temáticos encontra-se não em um repertório formal único, mas em seu objetivo, pois a representação formal desta finalidade comum - a venda ou propaganda - é múltipla. O temático poderia se aproximar do ecletismo pelas referências a épocas e culturas distintas, a fim de incorporar o valor implícito em tais referências. Porém, na realidade, a utilização de signos arquitetônicos funciona como estrutura de suporte para a narrativa que acrescenta valores ao local. Assim, ornamentos, por 
exemplo, podem ou não ser interessantes à história narrada, e o figurativo, embora sempre apareça, pode surgir de forma mais ou menos incisiva, de acordo com o tema explorado.

Concluímos que uma das principais características que identificam um Espaço Temático é a existência de uma narrativa. A concepção de um Espaço Temático funde elementos em uma cenografia que simula um local existente ou cria um espaço novo, de alguma forma ligado ao tema empregado. Portanto, o tema que passa a nortear toda a concepção do espaço nada mais é que uma história a ser contada. O que torna um espaço temático é, antes de tudo, o tratamento cenográfico, alegórico e lúdico, empregado para narrar a história, o tema.

Esta narrativa pode ser apresentada segundo duas vertentes. O estabelecimento pode tanto apropriar-se de uma história conhecida e evocá-la através de sua ambientação ou criar uma história inédita para ser adotada como tema. No entanto, ainda que a história não seja nova, há sempre uma forma particular de contá-la. Para valorizar ao máximo o estabelecimento, o enfoque é dado, invariavelmente, no lado positivo, no aspecto de maior qualidade que a história possa oferecer.

Assim, uma possibilidade para definição da temática adotada é a criação de uma narrativa exclusivamente para justificar o Espaço Temático. Neste caso é realmente concebida uma história que conta como teria, de acordo com a fantasia apresentada, surgido o espaço em questão. Durante a fase inicial de concepção do projeto, estas histórias podem funcionar como suporte para os profissionais envolvidos. Após a abertura ao público, identificamos, dentro desta opção de construir uma narrativa fictícia especialmente para o Espaço Temático, duas linhas. Em algumas situações, esta espécie de mitologia do espaço ainda é contada aos freqüentadores, em outras funcionou, principalmente, como um briefing para direcionar o projeto, não sendo contada aos visitantes.

Um exemplo do primeiro caso seria o parque aquático Blizzard Beach, parte integrante do complexo Disney World. O parque foi concebido seguindo a história fictícia de que uma tempestade de neve haveria caído sobre o Estado da Flórida, cobrindo a maior montanha da região, permitindo a constru- 
ção da primeira estação de esqui do Estado. Logo, com o calor típico do clima local, a neve derretida teria originado as cor6. THE IMAGINEERS. (1996). redeiras e piscinas existentes no parque aquático. ${ }^{6}$ Portanto, a pp.26-27. inspiração em estações de esqui norteia todo o projeto do parque que recebe um tratamento cenográfico de neve. A história é contada aos freqüentadores como uma lenda que teria dado origem ao parque e que justifica sua existência.

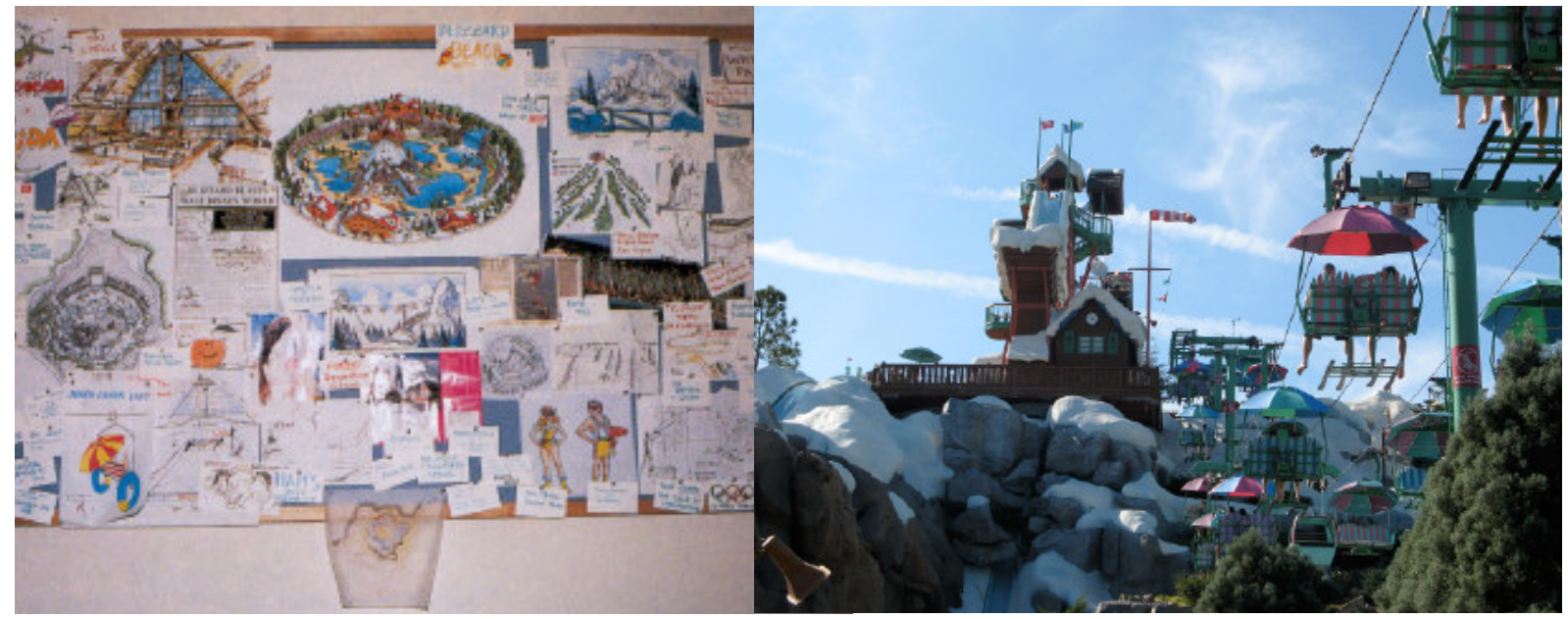

Figs 19 e 20. Quadro de idéias construído durante a fase de projeto e Blizzard Beach pronto.

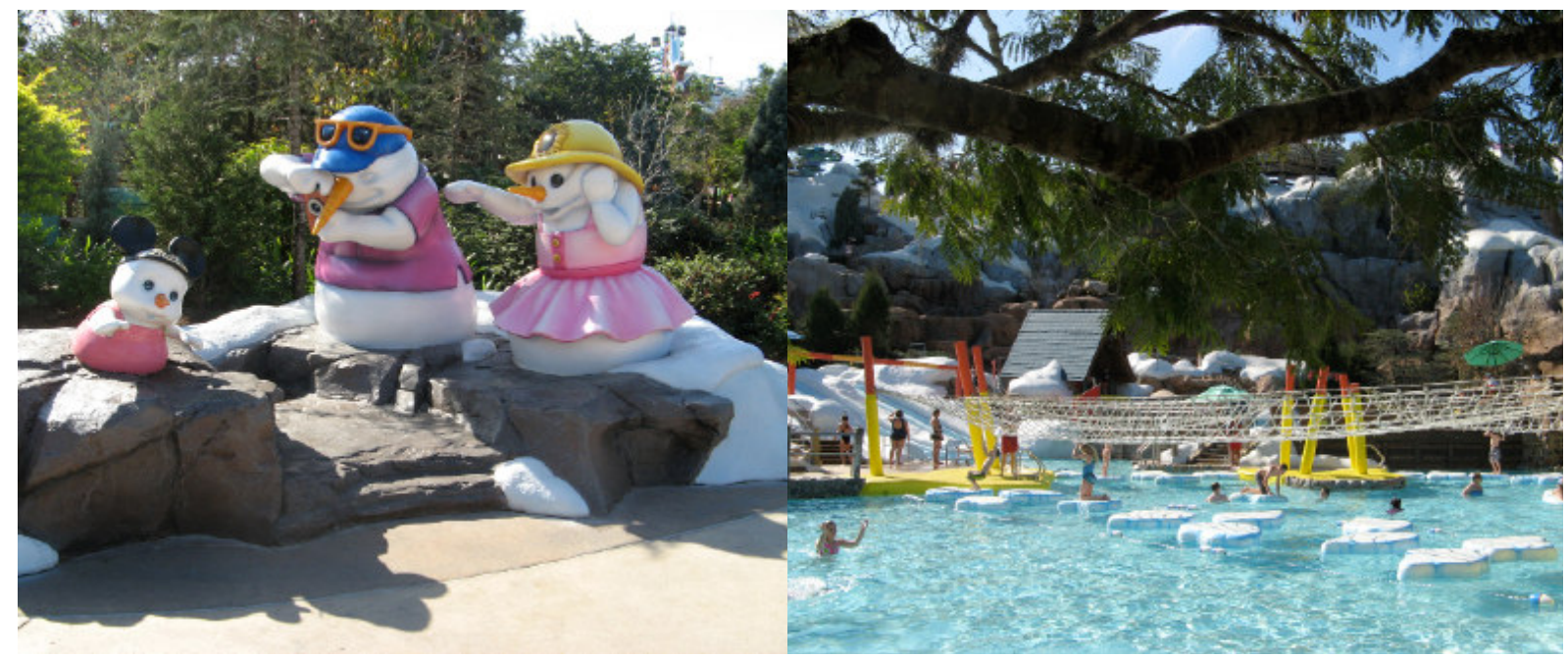

Figs 21 e 22. Blizzard Beach - "bonecos de neve" na entrada do parque e "blocos de gelo" na área infantil.

Citando um exemplo brasileiro temos o parque Hopi Hari, em Vinhedo, São Paulo, cuja mitologia complexa é contada aos visitantes para justificar a coexistência de áreas temáticas tão distintas quanto o "velho oeste" e o "Egito antigo". 7 criação de um tema exclusivo para o empreendimento permite que se faça este processo inverso, moldando a história para justificar aquilo que se deseja incluir. Entretanto, é preciso que o visitante acredite no que está sendo dito. Narrativas 


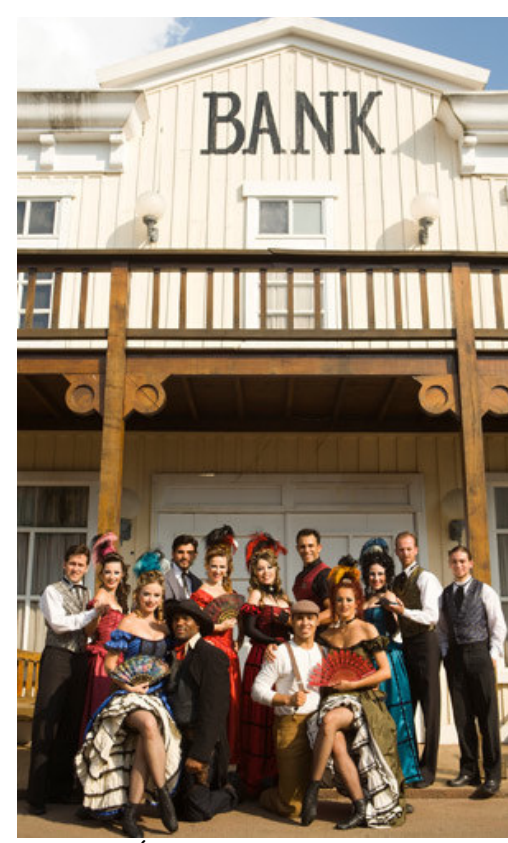

Fig 23. Área temática Wild West, em Hopi Hari.

tão complexas como a do Hopi Hari provavelmente não serão lidas pelo público que enxerga apenas um parque de diversões com áreas temáticas, sem entender como estão conectadas.

Há casos em que é criada uma lenda depois não contada para o público, mas que funciona como ponto de partida para o projeto. Foi o ocorrido com outra área em Walt Disney World, o Pleasure Island, conjunto de boites, bares e restaurantes. O mito dizia que a área onde fica atualmente o Pleasure Island fora, durante o século XIX, um distrito industrial cujo dono, Merriweather Pleasure, havia sido um aventureiro. Pessoas de todo o mundo o procuravam para contar sobre suas experiências, incentivando-o a abandonar os negócios e partir em busca de novas aventuras. Seus filhos, que teriam herdado a empresa, também a abandonariam ao receberem notícias de que seu pai estaria perdido em alto mar. O espaço teria entrado em decadência, sendo redescoberto, anos mais tarde, pelos

7. Justificativa temática para o hopi Hari encontrada na seção "história" do site official do parque. In http://www. hopihari.com.br/história:

"Existem várias interpretações para o surgimento de Hopi Hari, mas nenhuma apresenta provas que possam ser consideradas verdadeiras. Uns contam que Hopi Hari nasceu como um presente que o grande Hopi, deus da alegria e sobrinho de Zeus, deu para sua amada Hari, deusa da aventura. Outros afirmam que Hopi Hari é o lugar onde os viajantes do tempo descansam e vivem a vida. E alguns mais místicos ainda, crêem que Hopi Hari seria uma colônia de férias de extraterrestres superiores que habitam a Via Láctea.

KAMINDA MUNDI foi a primeira morada dos fundadores de Hopi Hari. Para lá foram pessoas de toda parte do mundo, onde construíram suas casas com fachadas que lembram a arquitetura de seus países de origem. O nome "Kaminda Mundi" quer dizer "Caminho do Mundo" em Hopês. Kaminda Mundi combina uma vida cultural intensa (é nessa região que fica o maior teatro do país e o cinema 3D) com uma das maiores rodas-gigantes do mundo e uma torre de onde você "despenca" de uma altura de 69 metros.Com o passar do tempo, o número de crianças de Hopi Hari não parou de crescer e logo precisaram de um grande parque para se divertir. Foi então que se decidiu pela criação de uma região onde as crianças pudessem brincar tranqüilas. Surgiu INFANTASIA!

A CONSTRUÇÃO DA CAPITAL

Hopi Hari tornou-se um país lindo e precisava ter uma capital. Então foi determinado um local para a construção e começou a preparação do terreno. Neste momento, uma grande surpresa aconteceu. Durante as escavações, descobriu-se um inacreditável sítio arqueológico, cheio de pirâmides, tumbas e "Katakumbas". Essa região misteriosa foi chamada de MISTIERI e é nela que encontra-se a Montezum, a quinta maior montanha-russa de madeira do mundo. Com $1.200 \mathrm{~m}$ de extensão e $105 \mathrm{~km} / \mathrm{h}$ de velocidade, ela garante fortes emoções com suas curvas acentuadas. Imagina-se que a Montezum é branca porque foi construída com ossos de dinossauro!! Por isso, o projeto da capital foi transferido para um dos mais belos recantos de Hopi Hari, a fronteira norte-nordeste, junto ao grande lago. Depois de pronta, a capital ficou o máximo! Lá tem de tudo. Tem o maior restaurante de Hopi Hari, o Chevrolet Mundi e, para radicalizar, há o looping do Katapul e o vôo delirante do Hadikali. A capital recebeu o nome de ARIBABIBA que quer dizer "viva a vida com alegria", a idéia que resume a filosofia de vida dos seus cidadãos, e de todos os hópius e hópias.

WILD WEST Afastada das outras regiões de Hopi Hari, fica Wild West.

Contam que um dia um hópiu estava lá no Rio Bravo pescando, quando descobriu uma pepita de ouro. No dia seguinte o mundo inteiro já estava sabendo. A notícia chegou aos Estados Unidos, no Oeste americano. Não deu outra. Arrumaram as carroças, fizeram um comboio para Hopi Hari e se estabeleceram ao lado de Kaminda Mundi. Eles têm xerife, dançam cancã no Saloon e duelam na rua. Têm até idioma próprio, o gringo, um dialeto que mistura o inglês e o hopês. Agora que você já sabe a história do nosso Kantri (país), venha viver sua história divertida em Hopi Hari." 
8. Walt Disney convencionou chamar os profissionais da área de criação das atrações dos parques Imagineers, junção dos termos "imagination" e "engineer", algo como engenheiros da imaginação.

9. THE IMAGINEERS. (1996).
Imagineers $^{8}$, que realizaram a revitalização, transformando os galpões abandonados em restaurantes e boites. ${ }^{9}$ Esta história fictícia justificava todo o projeto, já que estaria sendo retomada a vocação original do local de atrair aventureiros, fechando um ciclo. Já em sua inauguração não havia no complexo qualquer referência à mitologia adotada na fase de concepção. Desde setembro de 2008, as boites foram fechadas e o Pleasure Island vem funcionando apenas como centro comercial, com lojas e restaurantes. É possível que, em breve, outra narrativa substitua a mitologia atual, entretanto ainda não foi divulgado o que acontecerá com o espaço.

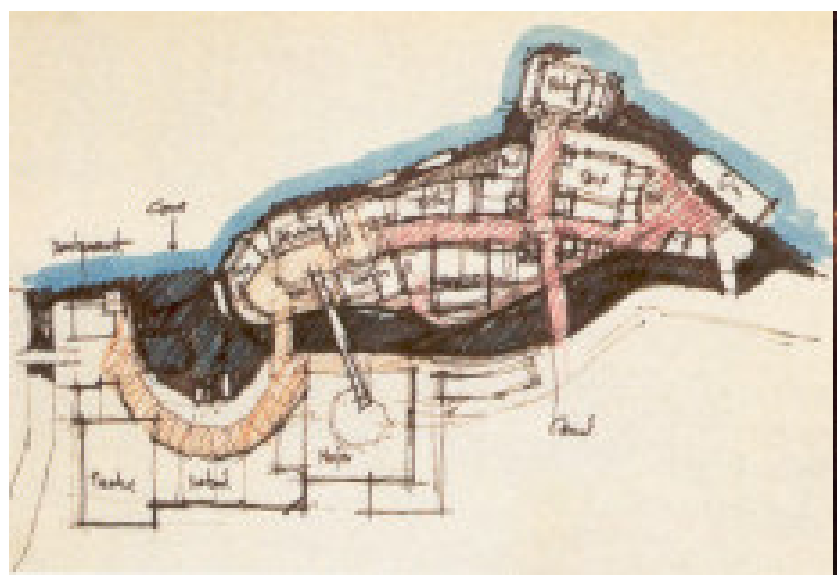

Já entre os espaços que se inspiram em uma história previamente difundida, como ocorre na maioria dos parques temáticos, há os que se baseiam em contos infantis, personagens, personalidades, locais de apelo turístico ou outras histórias já bastante conhecidas. Espaços vinculados a celebridades, por exemplo, adotam uma temática biográfica, contam, em geral mitificando o personagem, a história de vida da personalidade que se torna o tema do local. É o caso do já citado All Star Cafe, cuja temática foi baseada na vida de esportistas de sucesso, sócios do empreendimento, bem como do Michael Jordan's Restaurant, em Chicago, já fechado, mas que incluía em sua decoração toda espécie de relíquias que faziam referência ao astro do basquete. Como no restaurante de Jordan, o All Star Cafe incluía, em cada uma de suas filiais, fotos autografadas, uniformes, troféus ou qualquer outra peça associada aos atletas/personalidades. Aqui no Brasil, especialmente no Rio de Janeiro, ainda no ramo dos esportes, já patrocinaram res- 


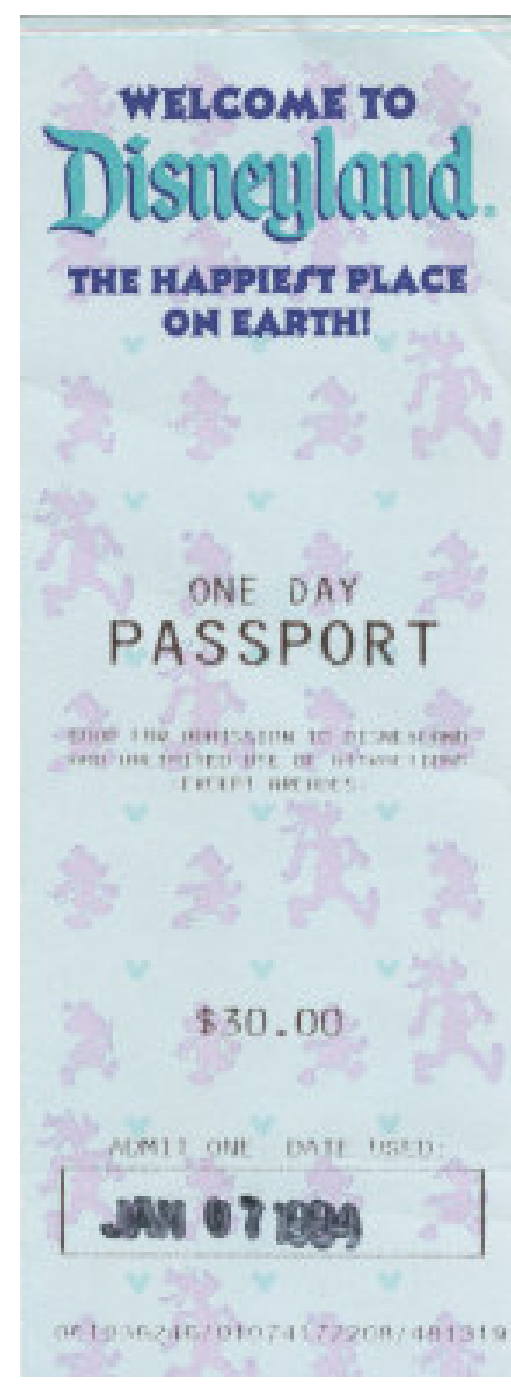

Fig 26. Ingresso para Disneyland com o slogan do parque.

10. "O lugar mais feliz da Terra." Ver capítulo 3.3 taurantes/casas noturnas temáticos jogadores de futebol reconhecidos mundialmente como Zico (Espaço Zico), Ronaldo (R9) e Romário (Café do Gol), todos já fechados. O levantamento feito nos leva a crer que a vida útil de estabelecimentos temáticos sustentados por celebridades tende a ser proporcional à capacidade do ídolo de se manter em evidência.

A presença de personagens que identifiquem o tema, embora freqüente, não é essencial. Até pela associação inconsciente com os parques temáticos ligados a personagens infantis e cartoons, poderíamos imaginar que a personagem inspiradora é fundamental para a concepção do Espaço Temático, porém, como foi visto em exemplos anteriores, o espaço não precisa necessariamente contar a história de uma personagem. Afinal, a narrativa orienta a construção do Espaço Temático, principalmente porque o próprio freqüentador torna-se personagem da história contada.

Seja qual for a temática inspiradora, os Espaços Temáticos possuem em comum a busca pela construção de uma realidade alternativa que permita a total imersão do visitante no tema retratado. Em casos de sucesso como o dos parques da Disney, quando o tema inspirador é conhecido, sabe-se que somente a parte agradável da história é narrada nas atrações que a envolvem. Conta-se a história não como ocorreu realmente, mas como se considera que deveria ter ocorrido, afinal estamos tratando de "mundos perfeitos". Embora em nenhum momento fique claro para o visitante que grande parte da história é deixada de lado, o próprio slogan da Disneyland - "The happiest place on earth" evidencia a intenção de construir mundos perfeitos e, conseqüentemente, ficcionais. ${ }^{10}$

Assim, vimos que são criadas representações idealizadas da realidade e, portanto, espaços que não existiriam mesmo no local ou tempo retratado. Além disso, nos Espaços Temáticos, elementos reproduzidos artificialmente são de um detalhismo tal que se assemelham verdadeiramente ao real. Com isso, cria-se um estado de permanente dúvida entre o que seria natural e o que foi construído com tecnologia apropriada. Durante muito tempo foi este o caso dos animatronics, robôs com movimentos então extremamente reais, representando humanos ou animais encontrados nos rides e shows de 
parques temáticos. Hoje, com o desenvolvimento tecnológico, fica mais clara a percepção de que estes movimentos não são tão realistas quanto se propõem. No entanto, os visitantes parecem não se importar, permanecendo fascinados com os brinquedos; o público deseja acreditar. A questão levantada aqui é de que cada vez menos importa o que é real ou não, inclusive, em muitos casos, o falso é preferido para "atingir maior perfeição".

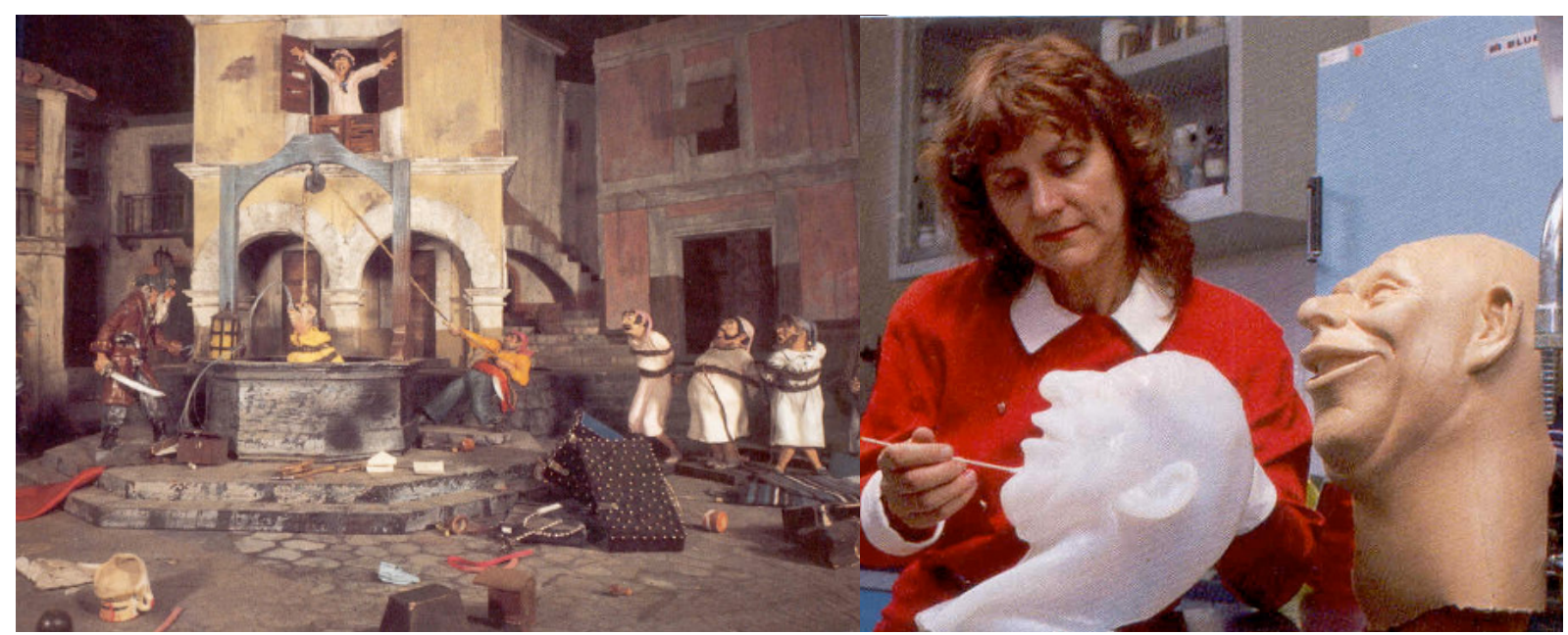

Figs 27 e 28. Animatronics no brinquedo Pirate's of the Caribbean e em confecção.

Para que o público se envolva imediatamente no contexto do tema, e perceba com clareza a história narrada, a linguagem utilizada costuma ser bastante figurativa e de rápida apreensão. Os Espaços Temáticos costumam explorar símbolos conhecidos que são instantaneamente associados à narrativa apresentada, identificando-a. De forma metonímica são reproduzidos ícones comumente associados ao tema adotado, como se, por exemplo, em um bar mexicano, toda a essência da cultura representada estivesse presente em sombreros e outros equivalentes.

Por outro lado, podemos pensar que quanto maior a

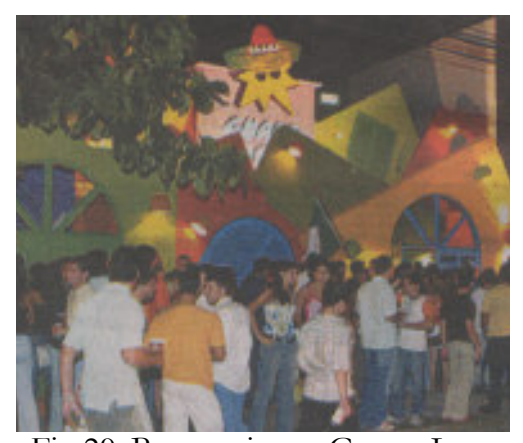

Fig 29. Bar mexicano Guapo Loco; Rio de Janeiro. imprevisibilidade do tratamento dado ao tema, desde que este seja facilmente identificável, maior a chance de seduzir o público. Se tratamos de espaços de lazer que primam pela imersão, é evidente que o tema deve ser absorvido de forma aparentemente natural, mas alguma imprevisibilidade certamente tornará esta apreensão algo lúdico. Após a percepção inicial do tema, em um segundo momento pode-se promover a identificação de novos elementos atraentes, e apontá-los pode se 


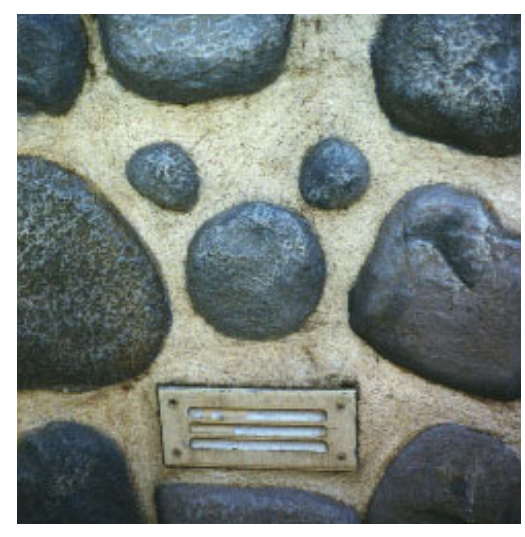

Fig 30. Hidden Mickey em parede de pedra no Magic Kingdom, em Walt Disney World.

mo prédio a imagem de Mickey Mouse aparece nos encostos dos assentos e nos armários. Ainda que os símbolos e personagens sejam bastante conhecidos, as situações em que são apresentados são um tanto quanto inusitadas, mesmo porque se trata de um edifício corporativo, não de um parque.
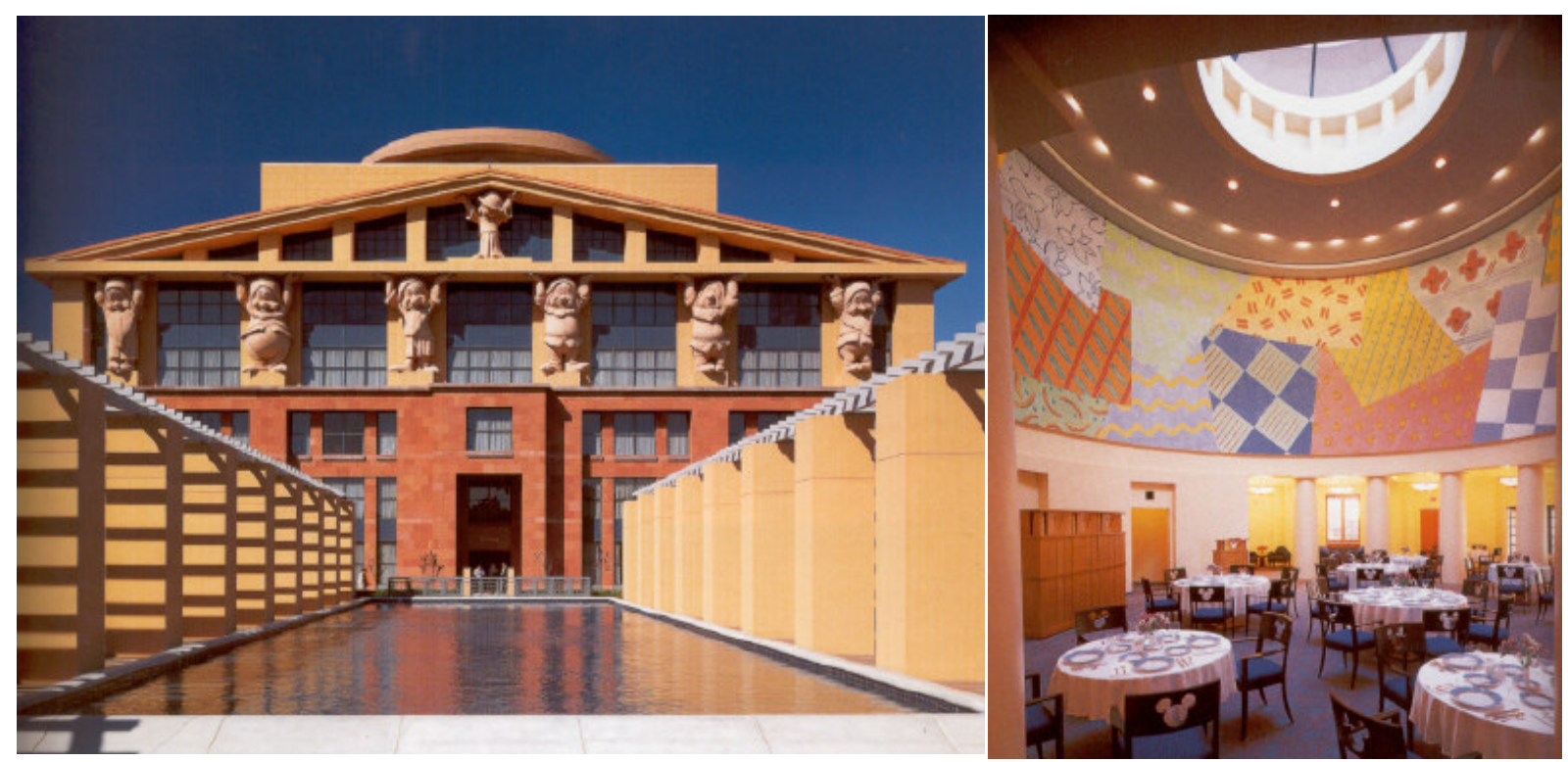

Figs 31 e 32. Team Disney Building - fachada e restaurante.

A narrativa contada nos Espaços Temáticos pode, então, ser analisada sob a ótica da associação feita por Gillo 11. DORFLES (1972) pp.47-49. Dorfles ${ }^{11}$ entre design e teoria da informação. Segundo esta relação, quanto maior a imprevisibilidade do tratamento dado ao tema, ou seja, da informação transmitida, maior a chance do objetivo do estabelecimento ser atingido. Isto caso a aceitação do tema proposto seja positiva. Assim, o projeto será considerado mais eficiente do ponto de vista comercial conforme sua capacidade de transmitir proporcionalmente maior quantidade de informação, envolvendo ainda mais o público 
no espaço. Os Espaços Temáticos podem atribuir parte de seu sucesso a esta oferta de algo diferente, com foco no inusitado, no nonsense.

Além disso, seguindo a lógica de transmitir a maior quantidade de informação possível, na maioria dos casos estes espaços oferecem experiências multissensoriais, incluindo além das referências visuais, temperatura, sons, umidade e aroma que o público identifique com o tema. A transparência do tema em diferentes níveis sensoriais segue o princípio de que quanto maior a intensidade da informação, maior a imersão do visitante no Espaço Temático. Ambientes cuja narrativa evoca temas assustadores, costumam usar temperaturas mais baixas para acentuar a sensação de arrepio e desconforto. Já reproduções de florestas e temáticas associadas à natureza incluem sons de animais e ambientes mais úmidos, por exemplo.

Este conjunto multissenssorial de informações, mais sutil que a referência visual, funciona bem para marcar a transição entre áreas temáticas distintas no caso de espaços que incluem mais de um tema ou sub-temas. Em grandes parques, onde a setorização é marcada por diferenciações temáticas, até o piso costuma sofrer alterações em sua textura, por exemplo. $\mathrm{O}$ visitante percebe inconscientemente, através do tato, que se trata de um espaço diferente.

Podemos, então, pensar que a velocidade e intensidade com que se percebe a narrativa praticamente não deixam margem para que o freqüentador reflita racionalmente sobre o espaço, reduzindo a capacidade de análise crítica. Com a grande carga de informação que recebe, o visitante não tem a oportunidade de perceber criticamente o espaço, tornando-se imerso no conjunto. Assim, reduzindo ao mínimo a quantidade de elementos que não estejam associados ao tema, cresce o envolvimento lúdico do freqüentador com o espaço, afinal qualquer elemento dissonante pode lembrar a "realidade".

Portanto, em projetos temáticos, a ambientação é pensada com o intuito de envolver o público no tema proposto, em intensidade tal que promova alienação em relação a tudo que é externo ao Espaço Temático. O tema configura-se como motivador para que o freqüentador sinta-se transportado para 
12. "A imaginação é o modelo a partir do qual a realidade é criada." In. DUNLOP (1996) p.14. outro local, pois, ao envolver-se emocionalmente com a temática, descarta temporariamente sua "realidade". Podemos pensar os Espaços Temáticos enquanto locais de fuga, espaços em que se busca, com a cenografia, construir um ambiente ao mesmo tempo inusitado, surpreendente e verossímel. A concepção espacial aqui se propõe a concretizar, ainda que de forma ilusória, a fantasia da viagem a outros mundos.

Para que o visitante abstraia a realidade externa ao Espaço Temático, é preciso que este tenha credibilidade, ou seja, que se acredite que aquele espaço desenhado no imaginário pode ser transposto para a realidade, e não que são apenas cenários falsos. Os Espaços Temáticos pretendem, então, aproximar-se de uma concretização de espaços desenhados no imaginário. A proposta desta arquitetura é, a partir do sonho e da fantasia, construir espaços concretos, verossímeis. Como afirmou Walt Disney, "Imagination is the model from which reality is created" $" 12$.

Vimos que, por um lado, a faceta alegórica da arquitetura está presente há muitos séculos. Entretanto o que é aqui entendido como temático está intimamente relacionado ao caráter comercial do espaço. A aplicação de temas em espaços contemporâneos surge com a necessidade de salvar os parques de diversão americanos, que se encontravam em período de decadência. Assim, embora o tema, ou ao menos a ornamentação alegórica, já existisse em outras situações, o surgimento destes Espaços Temáticos estudados obedece a um processo histórico concreto e pode, portanto, ser datado. Os Parques Temáticos surgiram devido à necessidade de incorporar um elemento novo que promovesse os antigos centros de lazer em decadência. Logo a aplicação de temas foi estendida a espaços comerciais de um modo geral, em uma estratégia de marketing que funciona ao tocar o lado emocional, induzindo o público a visitar o centro de entretenimento e consumir produtos ou serviços. Observamos a incidência do temático em espaços comerciais e de lazer que vendem mercadorias e serviços diversos, mas, em comum, vendem experiências.

Portanto, falamos de locais essencialmente auto-promocionais; além de todas as características expostas, o que mais contribui para enquadrá-los como temáticos é a própria 
intenção de sê-lo. Os Espaços Temáticos constituem entidades que se auto-legitimam. Colocar-se como temático nada mais é que parte de um projeto de marketing de lugar em que o tema é um atrativo extra. Parques, bares, restaurantes, casas noturnas, etc, passam a ter sua concepção orientada por um tema e a se auto-denominar parques temáticos, bares temáticos, restaurantes temáticos ou boites temáticas.

Pode-se concluir, então, que a intencionalidade é inerente à construção dos Espaços Temáticos. O objetivo principal, que justifica o acréscimo do tema na concepção de um estabelecimento, é o retorno financeiro obtido quando há maiores atrativos para o público. O tema se torna mais eficiente enquanto atrativo conforme é reduzida a quantidade de elementos dissociados da narrativa. Assim, os Espaços Temáticos são concebidos com inspiração em determinado assunto que é contado em seu espaço físico sob a forma de uma narrativa de fácil apreensão, repleta de símbolos reconhecíveis e fantásticos, proporcionando, então, uma imersão do freqüentador nesta história. A proposta é a da construção de um "mundo perfeito".

Este capítulo tem como propósito delimitar o conceito Cidades Temáticas que poderíamos chamar, em analogia aos Espaços Temáticos, de Cidades ou Regiões Temáticas, pois aqui a escala torna-se pouco relevante. Mais do que simplesmente tratar do local em si, a pesquisa se foca na relação estabelecida entre a arquitetura alegórica, narrativa, de apreensão imediata, enfim, temática, e a construção da identidade local. A reflexão proposta versa sobre a maneira como uma exploração temática de determinada região pode contribuir para alterar tanto sua identidade local reconhecida pelos habitantes quanto a imagem que ela divulga e deixa transparecer aos visitantes.

É preciso, primeiramente, estabelecer algumas características que identificariam uma região como temática, tarefa para a qual poderemos retomar o conceito apresentado de 13. ANDRADE (2004) "Espaço Temático"13. Entretanto, ao contrário destes estabelecimentos temáticos, que se auto-legitimam como tais, incorporando a identificação em seu próprio título - bar temático, restaurante temático, etc - a associação de uma região com 
o modelo temático se daria, principalmente, pela utilização de elementos alegóricos que narram uma mesma história - o tema.

Ao analisar a aplicação da arquitetura temática como conhecemos hoje, podemos inferir que se trata de um fenômeno recente. A origem imediata deste processo configurou-se a partir da criação dos primeiros parques temáticos, durante a década de cinqüenta, mas notamos que o temático, pouco a pouco, ultrapassou a fronteira dos parques de diversão para se estender a inúmeras áreas, principalmente comerciais. O termo "Espaço Temático" engloba, então, locais nos quais fundem-se arquitetura, design e cenografia, locais em que a arquitetura transcende sua função tradicional para tornar-se responsável direta pelo entretenimento do usuário. Assim, o espaço arquitetônico não apenas abriga e interage com as ações que o envolvem, mas torna-se responsável pela principal delas. A arquitetura recebe a função de contar uma história, de ambientar o freqüentador, transportando-o para uma realidade fictícia. No entanto, ao contrário do que possa parecer a princípio, se descartarmos a característica comercial e pensarmos no temático como uma afirmação de poder, corporativo ou não, notamos que a idéia implícita no conceito de arquitetura temática pode englobar referências trazidas desde muito antes, inclusive em escala urbana. ${ }^{14}$

Assim, gradativamente extrapolando o reduto dos parques, uma temática, uma alegoria, passou a ser agregada ao espaço construído, seja qual for sua função, como forma de estabelecer uma identidade visual para o local, um aspecto diferenciado, um atrativo para o visitante. A publicidade atraída com o acréscimo do tema pode objetivar a transformação de espaços regulares de lazer em grandes atrações turísticas, ou fazer com que atrações turísticas pouco lembradas ganhem maior visibilidade, voltando-se para o turismo de massa.

Para entender como a temática extrapolou a fronteira dos parques, podemos recorrer a uma rápida revisão histórica. Os parques europeus, originalmente áreas verdes para piqueniques e passeios, haviam se consolidado, nos Estados Unidos, seguindo um modelo ligeiramente adaptado. Eram localizados ao final das linhas de bonde como atrativo para 
15. NATIONAL AMUSEMENT PARK HISTORIC ASSOCIATION. The Amusement Park Industry - a Very Brief History In. http:/www.napha.org. promover seu uso durante os finais de semana. Em 1929, com a crise na bolsa de valores de Nova York, os Estados Unidos entraram em depressão econômica e, em 1935, restavam apenas poucos parques de diversões. Além disso, a Segunda Guerra Mundial abalou consideravelmente a indústria. Neste momento, mais parques fecharam, enquanto os que resistiram se abstiveram de acrescentar novas atrações devido ao racionamento. ${ }^{15}$

No período pós-guerra, os Estados Unidos e, conseqüentemente, a indústria dos parques de diversões, desfrutaram de prosperidade. Público e renda atingiram recordes, enquanto novos parques eram abertos. Além disso, o baby boom após a Guerra influenciou a criação de um novo conceito, o Kiddieland, pequeno centro de entretenimento voltado para o público infantil incluído nos parques. Deste modo, os parques foram rapidamente incorporados à paisagem dos subúrbios crescentes. Contudo, o sucesso foi passageiro, pois já na metade do século XX, a chegada da televisão, a desagregação e decadência urbana, assim como o crescimento dos subúrbios, promoveram novo abalo nos então envelhecidos parques. Enquanto o público se satisfazia com novas formas de entretenimento, os parques novamente enfrentavam dificuldades. Sua manutenção foi possível graças ao novo conceito, encontrado com a criação da Disneyland. ${ }^{16}$

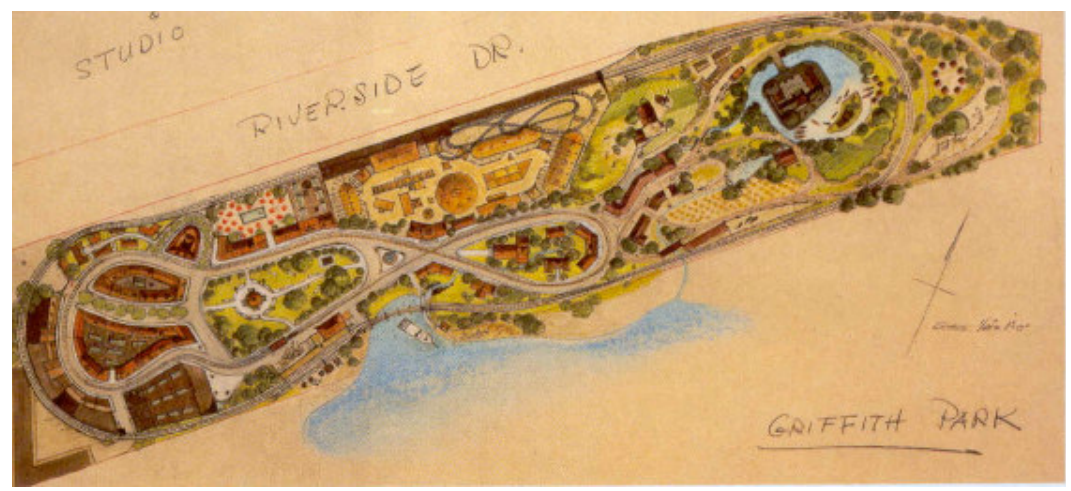

Fig 33. Um dos primeiros projetos para a Disneyland, ainda bem semelhanta aos parques tradicionais.

O parque idealizado por Walt Disney foi inicialmente inspirado em seu hobby, o ferromodelismo. Antes de conceber o parque, Walt construíra um modelo em proporções quase humanas em seu próprio jardim. Ao invés de seguir o modelo já conhecido, o parque foi dividido em cinco áreas temáti- 


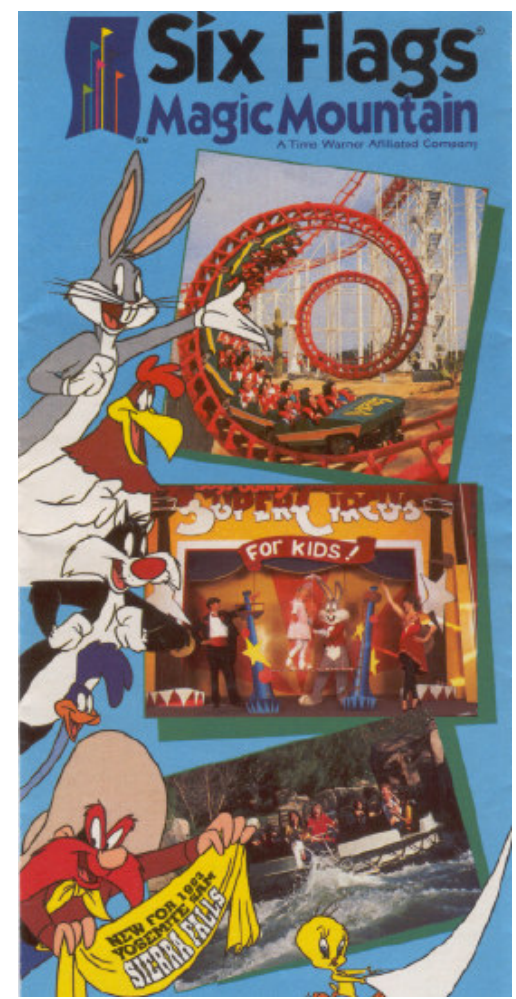

Fig 35. Folder para o parque Six

Flags Magic Mountain, incluindo os personagens da Warner Brothers. cas distintas interligadas por um percurso de trem. Com isso, propôs-se proporcionar aos freqüentadores a fantasia da viagem para terras e épocas diferentes. Disneyland tornou-se um sucesso imediato, dando início à era dos parques temáticos. Os novos parques passaram a seguir o modelo Disney e, logo, antigos parques associaram-se a empresas para incluir personagens e temas. ${ }^{17}$

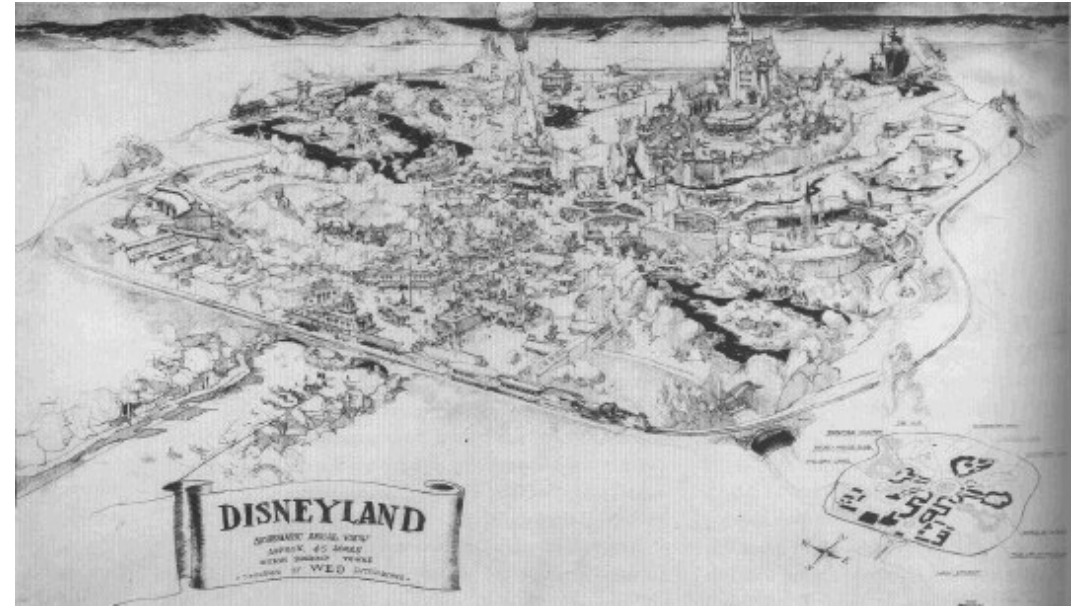

Fig 34. Projetos para a Disneyland, já setorizada em áreas temáticas e organizada segundo um eixo radial.

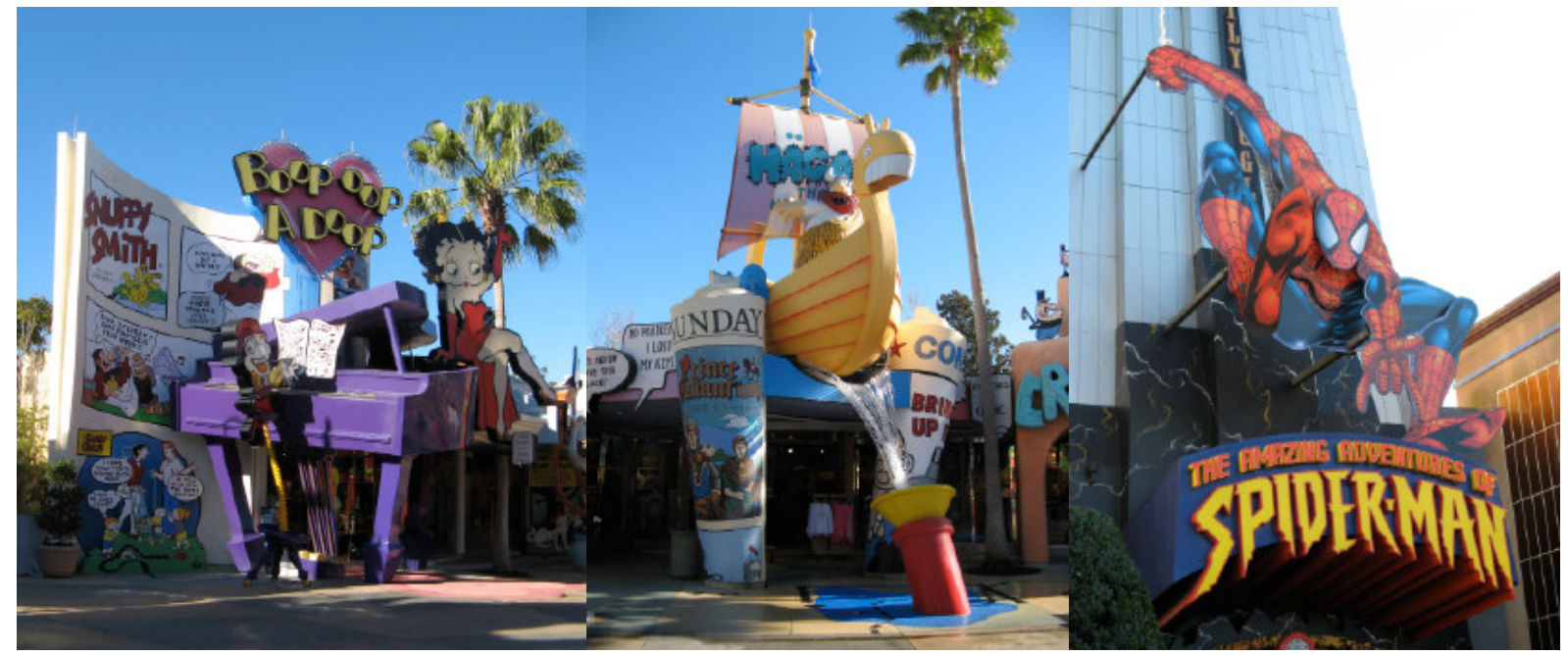

Figs 36, 37 e 38. Betty Boop, Hagar e Homem-aranha no Islands of Adventure, parque da Universal Studios.

17. A cadeia Six Flags, especializada em montanhas russas associouse a Warner Brothers para incluir personagens em seus parques. Em 1983, o tradicional parque Knott's Berry Farm inaugurou uma área temática denominada Camp Snoopy, fazendo referência ao famoso personagem e seus amigos. No Brasil, o Hopi Hari possui uma área para crianças menores sobre os personagens do programa infantil Vila Sésamo.
Hoje, uma das novidades encontrada nos parques é o que convencionaremos chamar de Centro Temático de Entretenimento. Trata-se de um anexo aos parques, normalmente localizado em sua entrada e constituído por um complexo de lojas, bares, cinemas, restaurantes e boites. Mais uma vez a Disney inaugurou um conceito ao criar a Disney Village, área que engloba restaurantes, espaços para shows, nightclubs, lojas, além de diversas outras atrações. Os demais grandes parques 
temáticos passaram a incluir em seus programas propostas semelhantes.

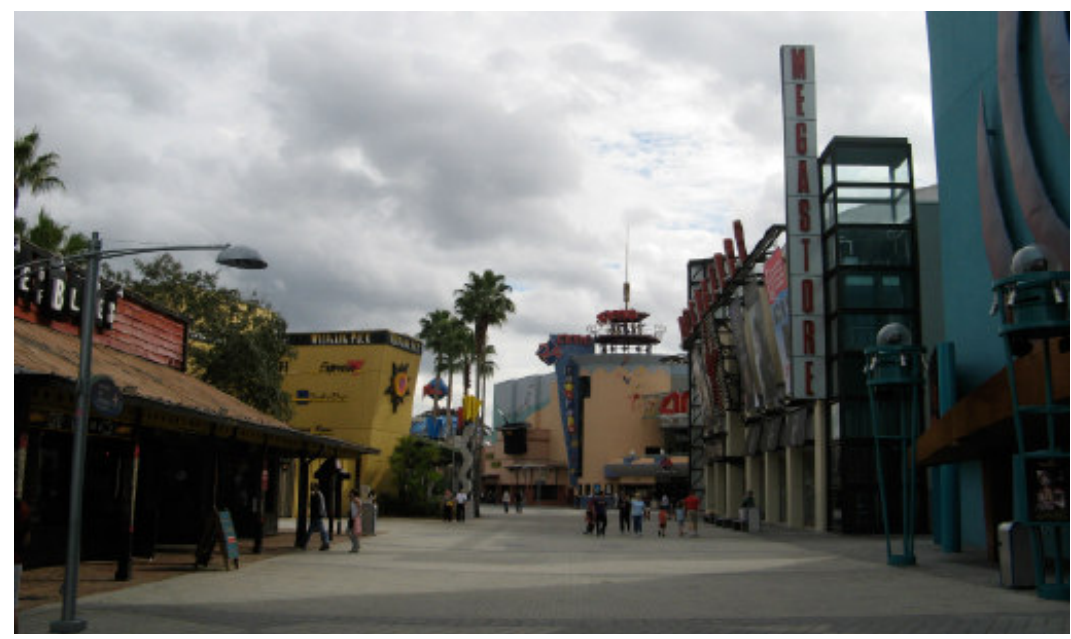

Fig 39. Disney Village, em Walt Disneyy World.

$\mathrm{Na}$ entrada da Universal Studios, em Los Angeles, está a Universal City Walk, uma rua com programa semelhante ao da Disney Village. O projeto de Jon Jerde partiu da idéia consolidada de que Los Angeles nada mais é que um conjunto de subúrbios, uma cidade sem cidade. Então, Jerde cria a cidade nesta rua temática, extrapolando todos os sentidos - gorilas agarrados às fachadas de edifícios comerciais, carros saindo das paredes - como se o mundo real encontrasse o cinema, tema do parque.

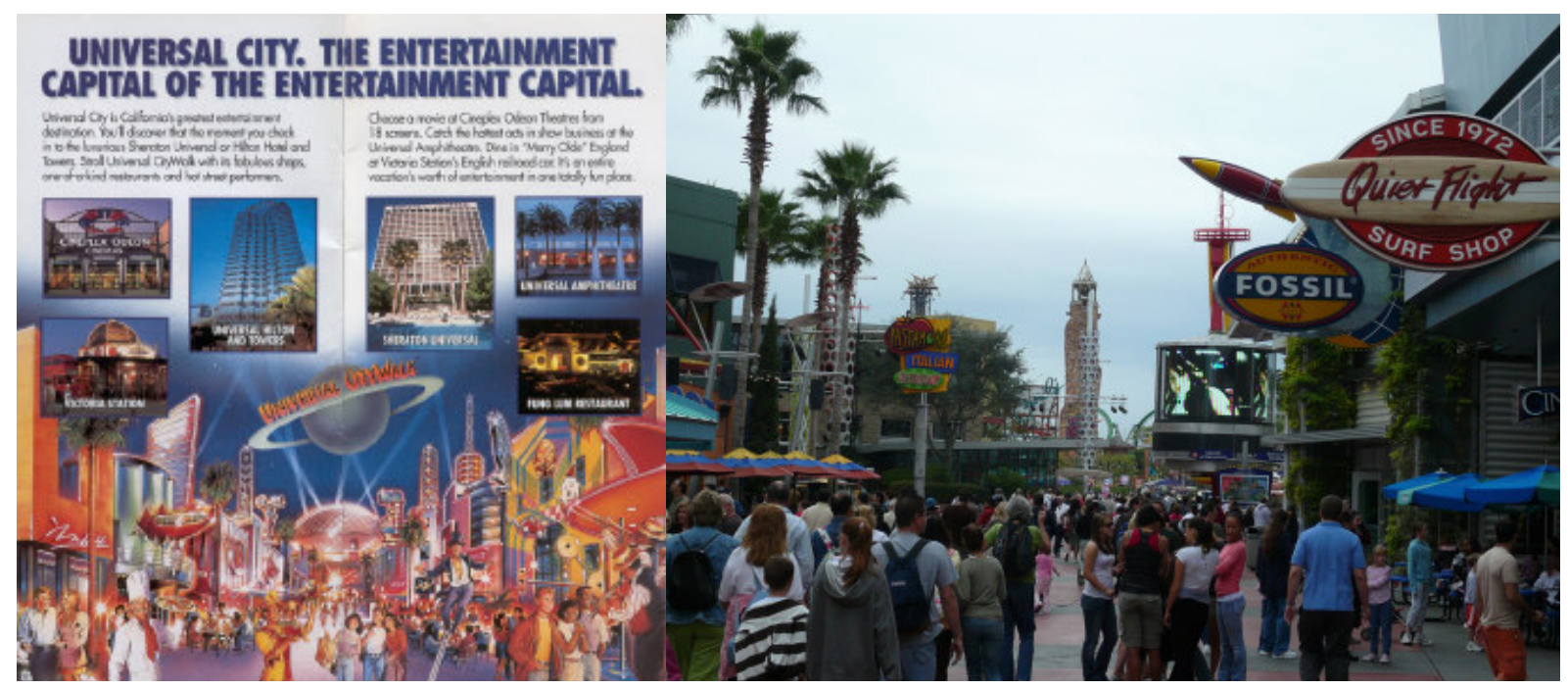

Figs 40 e 41. Folder para a Universal City Walk. Hollywood e Universal City Walk Orlando.

A própria Disney incluiu complexos como estes em mais dois de seus parques, na Califórnia e na França. A tendência atual, portanto, leva a crer que estes Centros Temáti- 
cos de Entretenimento podem ganhar força, tornando-se independentes dos parques. Um exemplo de que isso já ocorre pode ser identificado nos famosos cassinos temáticos de Las Vegas ou em shoppings temáticos, totalmente desvinculados de parques. Além disso, o uso de temas sai dos parques para ser levado a estabelecimentos de menor porte, como restaurantes, bares, lojas, e dinner shows.

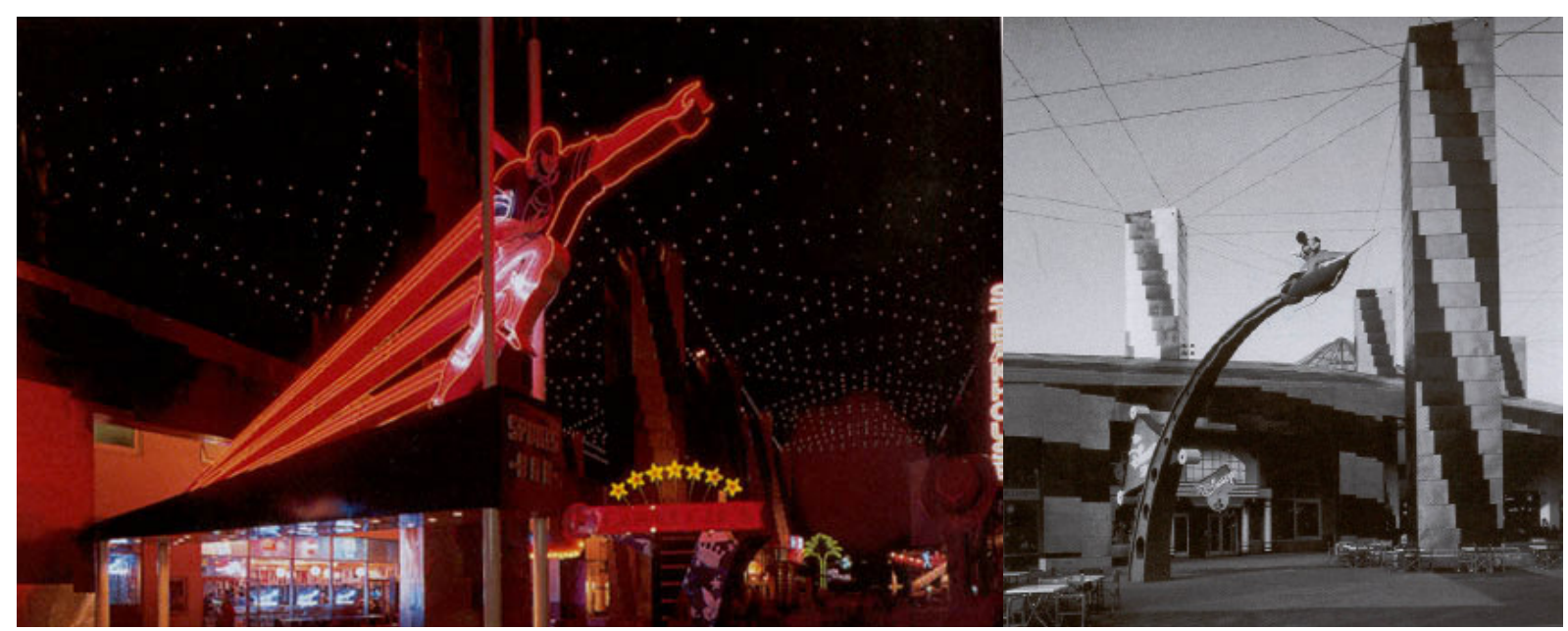

Figs 42 e 43. Disney Village, na Disneyland Paris.

Desta forma, a partir dos grandes complexos de lazer, o tema se desenvolveu como solução para atrair público maior e mais diverso, funcionando como elemento de comunicação e divulgação dos espaços. Hoje, o uso de temas excede o limite dos grandes complexos e atinge de pequenos estabelecimentos comerciais a grandes cadeias de lojas e franquias diversas, em

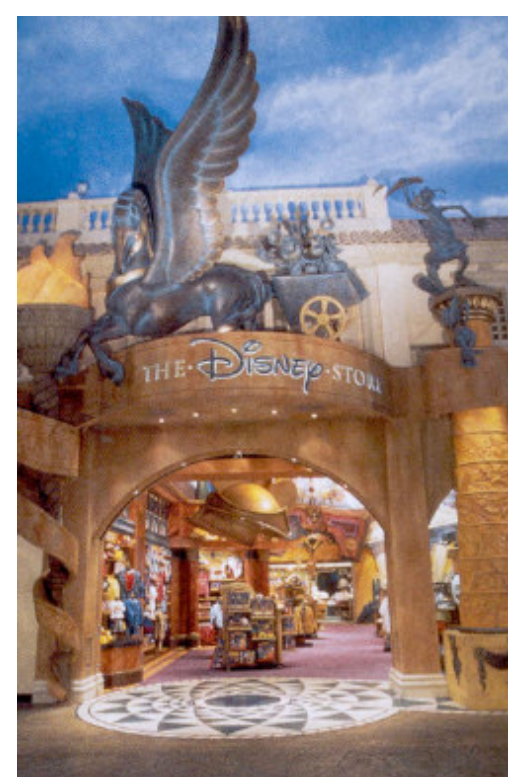

Fig 44. Disney Store; Las Vegas. um processo em que quando não há um tema a ser explorado, a própria marca é convertida em alegoria, conforme veremos a seguir.

Cada vez mais os Espaços Temáticos tornam-se superlojas com temática totalmente auto-referencial; marcas que se tornam temas de si próprias. Lojas como as Disney Stores ou Nike Towns vendem produtos exclusivos, mas, além disso, promovem a marca através de inúmeras referências diretas, permeando todo o espaço construído. O freqüentador é tão envolvido pelo conjunto quanto seria em um parque temático, ao mesmo tempo em que é fortalecida a identidade da marca. Conforme afirma Naomi Klein

$$
\begin{aligned}
& \text { "a idéia geral é criar um lugar que seja parte } \\
& \text { shopping center, parte parque de diversões, }
\end{aligned}
$$


18. KLEIN (2002) pp.174-175.

19. Ver Capítulo 3.3

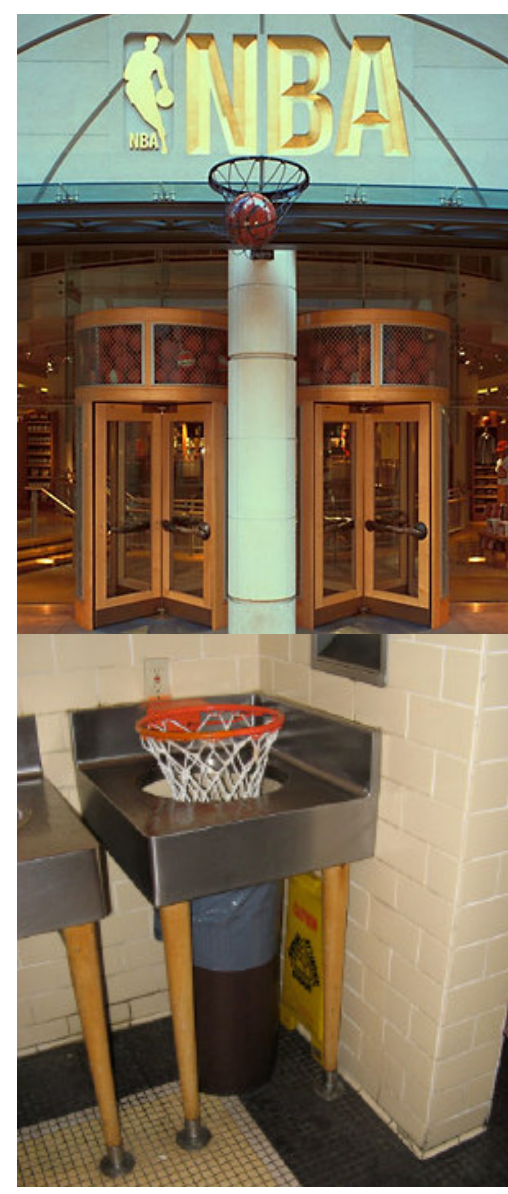

Figs 45 e 46. NBA Store; Nova York e cesto de lixo no sanitário do NBA City, no Universal City Walk.

20. LEACH, Neil. Escapist Introduction In. FRAUSTO, e OCKMAN (2005) p.117.

"We live in a culture of escapist dreaming, fueled by the midia. It is as though the only effective strategy for dealing with the horror vacui of contemporary existence has become a form of fantasy escapism, based on the role-playing and theming.

Television soap operas, movies, and pop-music videos, along with consumer magazines, provides us with catalogues of wish-images,

which we might incorporate into our lives and on which to model our selves. It is as though we have turned into animated mannequins, acting out lives according to the well-rehearsed steps of some Hollywood role model." parte performance multimídia - uma publicidade mais poderosa e evocativa que mil outdoors." 18

A grande questão envolvida no entendimento dos Espaços Temáticos, de um modo geral, é, portanto, a construção da imagem. Se, cada vez mais, compramos não produtos, mas idéias e experiências, faz sentido que a exploração temática seja incorporada a cidades turísticas que vendem justamente a experiência de vivenciá-las. Portanto, aos poucos a exploração temática como artifício para atrair o turista estendeu-se a espaços mais abrangentes, chegando a cidades inteiras. Hoje fica claro que este processo não se restringe a parques temáticos e, tampouco, a estabelecimentos estritamente comerciais, embora obedeça à ótica mercadológica. É possível identificar a incidência do temático inclusive em sítios arqueológicos e museus que recebem tratamento alegórico explorando sua própria história, com o objetivo de atrair divisas que promovam a auto-sustentabilidade financeira. ${ }^{19}$ Portanto vivemos em uma espécie de cultura do temático:

\begin{abstract}
"Vivemos em uma cultura de sonho escapista, alimentada pela mídia. É como se a única estratégia eficiente para lidar com o horror vacui da existência contemporânea fosse uma forma de fantasia escapista, baseada na atuação e tematização. Novelas, filmes e video clipes, junto com revistas, nos fornecem um catálogo de imagens-desejo, que podemos incorporar a nossas vidas e segundo as quais nos modelamos. É como se tivemos sido transformados em manequis animados, atuando em nossas vidas de acordo com os passos bem ensaiados de algum modelo Hollywoodiano." 20
\end{abstract}

Além disso, se identificamos situações em que a identidade corporativa era construída a partir de uma ambientação temática, percebemos um desdobramento deste processo a partir do momento em que se identificou que um processo análogo de construção de imagem através do temático poderia se estender ao marketing de cidades.

Locais como Memphis - a cidade de Elvis Presley, ou Lynchburg - a cidade do uísque, ambas nos Estados Unidos, exploram uma temática de reflexos alegóricos que faz parte, hoje, de suas identidades. Esta temática se evidencia através 
da arquitetura e do design de folders de divulgação, estabelecimentos comerciais, mobiliário urbano, e outros elementos presentes nas cidades que utilizam signos de associação imediata com o tema que, conseqüentemente, é associado ao próprio local. Da mesma forma, foi encontrada uma série de cidades ou regiões cujos símbolos de identidade local, tidos, atualmente, como "naturais", parte de suas histórias, haviam sido, na prática, construídos a partir de uma "tematização" da região. Identificamos, ainda, o caso inverso: cidades que, em oposição às que constroem a narrativa de sua história a partir de elementos cenográficos, trazem para sua paisagem elementos igualmente cenográficos, porém inspirados em aspectos de sua cultura. Nas duas situações, a identidade local é consolidada a partir da exploração alegórica de um tema prédeterminado.

No Brasil, por exemplo, a idéia de que "o tempo parou" costuma ser veiculada como propaganda de cidades - Petrópolis ou Teresópolis, por exemplo - que adotam ou mantêm modelos arquitetônicos de épocas passadas, e prometem ao visitante o retorno a esta época "tão boa". Cidades Históricas como Ouro Preto e Paraty, a exemplo da já citada Colonial Williamsburg adotaram uma preservação seletiva, procurando enaltecer o período colonial. Para tanto, não permitem construções que fujam da estética da época. Certamente esta imagem está associada a uma visão romântica acerca desta época passada e carrega, por conseguinte, uma carga da opinião construída pelo momento atual sobre este período anterior.

O mesmo ocorre em cidades como Solvang, na Califórnia, cuja arquitetura remete à tradição medieval européia, ou em alguma das várias cidades norte-americanas que restauraram suas ruas principais buscando semelhança com a Main 21. FJELLMAN (1992) pp.169-176. Street dos parques de Walt Disney World. ${ }^{21}$ O que passa a ser considerado como tipicamente europeu, no primeiro caso, ou original da cidade, no segundo, nada mais é que representação formal da imagem que se tem, no momento da construção, sobre a cultura e período retratados. Logo, a exploração temática de uma cidade pode alterar a narrativa de sua história; nestas cidades que restauraram suas ruas principais sob a ótica da Main Street de Walt Disney passou-se a acreditar naquela 
paisagem como sendo original. Podemos dar suporte a essa idéia tomando como referência o conceito de "invenção das 22. HOBSBAWN (2000) tradições" estabelecido por Eric Hobsbawn ${ }^{22}$, que busca identificar a construção de conceitos tidos como parte formadora de determinada cultura, ainda que tenham sido recentemente incorporados.

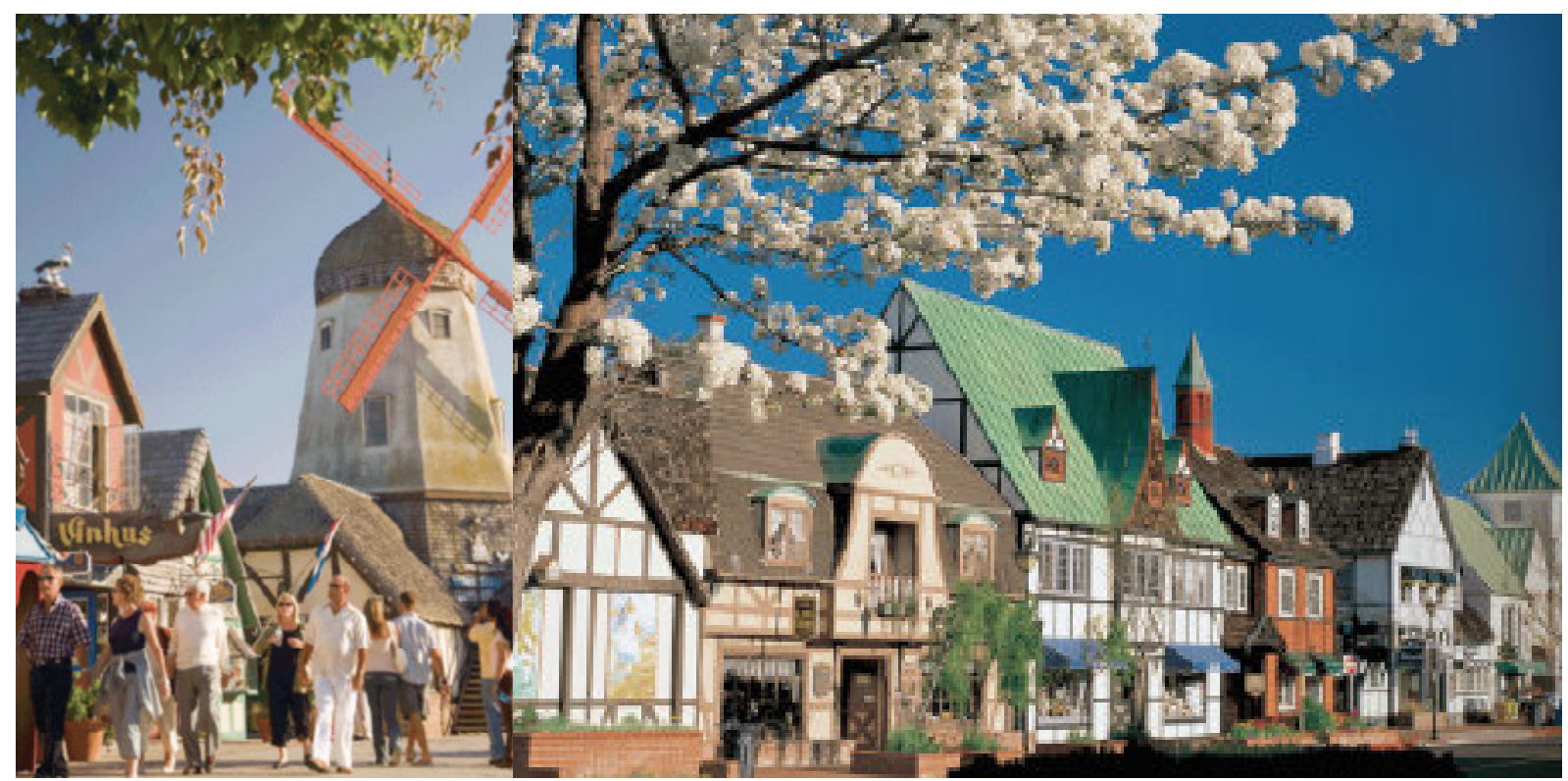

Figs 47 e 48. Solvang: os prédios referenciam a imigração dinamarquesa.

Assim, uma cidade ou região pode ser relacionada ao modelo temático quando grande parte dos elementos que configuram sua paisagem é inspirada diretamente em um mesmo tema que transparece de forma figurativa, objetivando a identificação imediata do tema narrado com o propósito claro de construir identidade e atrair visitantes e divisas. Esta região passa, então, a ser conhecida, divulgada e associada a esta temática predominante. Poderíamos questionar se cidades planejadas, sempre pensadas para refletir a identidade que se deseja representar, não seriam automaticamente temáticas. Entretanto, a maior parte destas cidades busca um estilo arquitetônico consagrado como elemento de reforço identitário,

23. Ver Capítulo 3.1 sem necessariamente explorar uma temática figurativa. ${ }^{23}$

A princípio, identificamos duas formas de ocorrência do modelo temático no espaço urbano. A primeira hipótese considera a inclusão de um tema que, inicialmente, não estabelece qualquer tipo de relação com o local, mas se torna, posteriormente, sua maior referência. O exemplo mais emblemático do modelo temático - o complexo Disney World, na Fló- 
24. VENTURI, SCOTT-BROWN e IZENOUR (2001) Ver Capítulo 1.3

25. Ver Capítulo 3.2

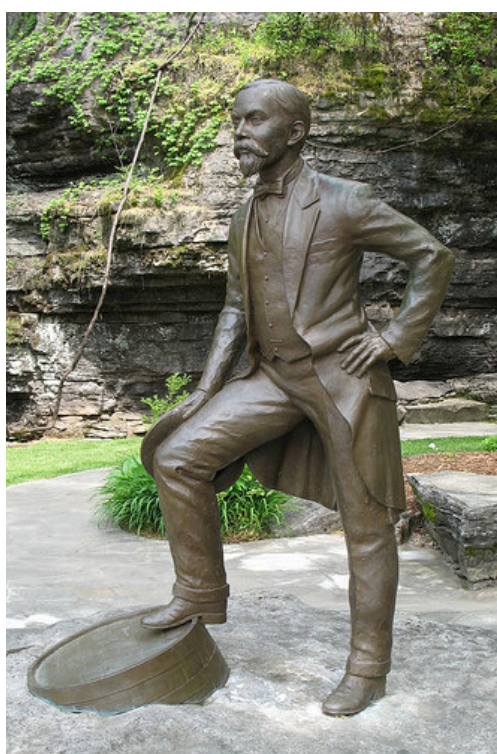

Fig 49. Estátua de Jack Daniel, o fundador da destilaria, em Lynchburg.

26. http:/ /www.bigthings.ca/ ontario/colborne.htm

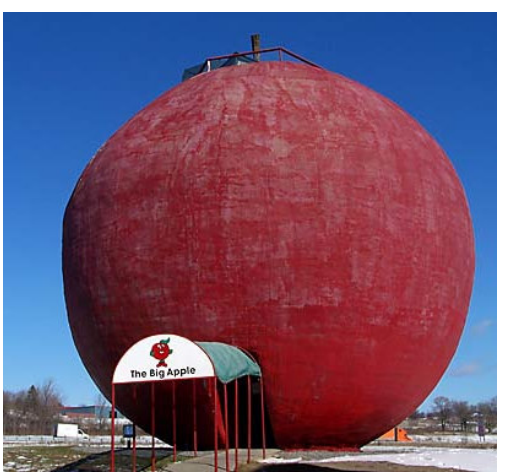

Fig 50. Big Apple, em Colborne. rida - fez com que a cidade de Orlando se enquadrasse neste caso. A área onde foi construído o complexo, originalmente um enorme pântano, não possuía espécie alguma de vínculo, a priori, com a temática dos personagens de Walt Disney. No entanto, o sucesso do empreendimento fez com que fossem construídas atrações menores de temática análoga, a ponto de associarmos a cidade exclusivamente aos parques temáticos ou à figura simbólica de Mickey Mouse. As principais vias de acesso à cidade foram tomadas, a exemplo da Strip de Las Vegas analisada por Robert Venturi ${ }^{24}$, por elementos simbólicos que pretendem atrair o consumidor. Embora esta imagem tenha sido recentemente construída, é utilizada como divulgação da cidade para o turista e tornou-se difícil imaginar Orlando de outra forma. ${ }^{25}$

Uma segunda hipótese considera a exploração temática de assuntos que carreguem alguma associação com o local. Esta situação pode ser exemplificada pela já mencionada "cidade do uísque" - Lynchburg, onde foi fundada a destilaria do famoso bourbon norte-americano Jack Daniel's. Outro exemplo interessante, Colborne - Ontário, no Canadá, auto-proclamada "cidade da maçã", deve seu tema a uma grande plantação préexistente da fruta. Hoje, no entanto, a idéia é explorada através de um referencial simbólico bastante figurativo - a estrada que leva à cidade conta com uma maçã cenográfica de pouco mais de 11 metros de diâmetro. Este marco da paisagem, devidamente acompanhado por uma confeitaria em que são vendidos exclusivamente produtos derivados da maçã, tornou-se ponto de parada para viajantes, fortalecendo-se como referência e símbolo da cidade. ${ }^{26}$ Esta espécie de marco localizada nas saídas de acesso para a cidade tornou-se, nas últimas décadas, bastante recorrente no norte dos Estados Unidos e Canadá.

Seguindo a mesma idéia de explorar temáticas reconhecidas a priori, certas regiões fazem uso de elementos cenográficos pontuais, ou seja, mesmo que a cidade possua outros referenciais simbólicos mais fortes, algumas incidências alegóricas contribuem para fortalecer esta simbologia. Pode ser citado o exemplo de Salvador, no Brasil, com seus telefones públicos construídos em formato de cocos ou berimbaus. Os telefones em si não constituem propriamente símbolos de 
identificação, mas através de uma representação figurativa, remetem à praia e à música típica - elementos formadores da identidade da cidade. Não seria o caso de entender a cidade como temática, mas, sem dúvida, encontramos elementos temáticos permeando seu espaço.

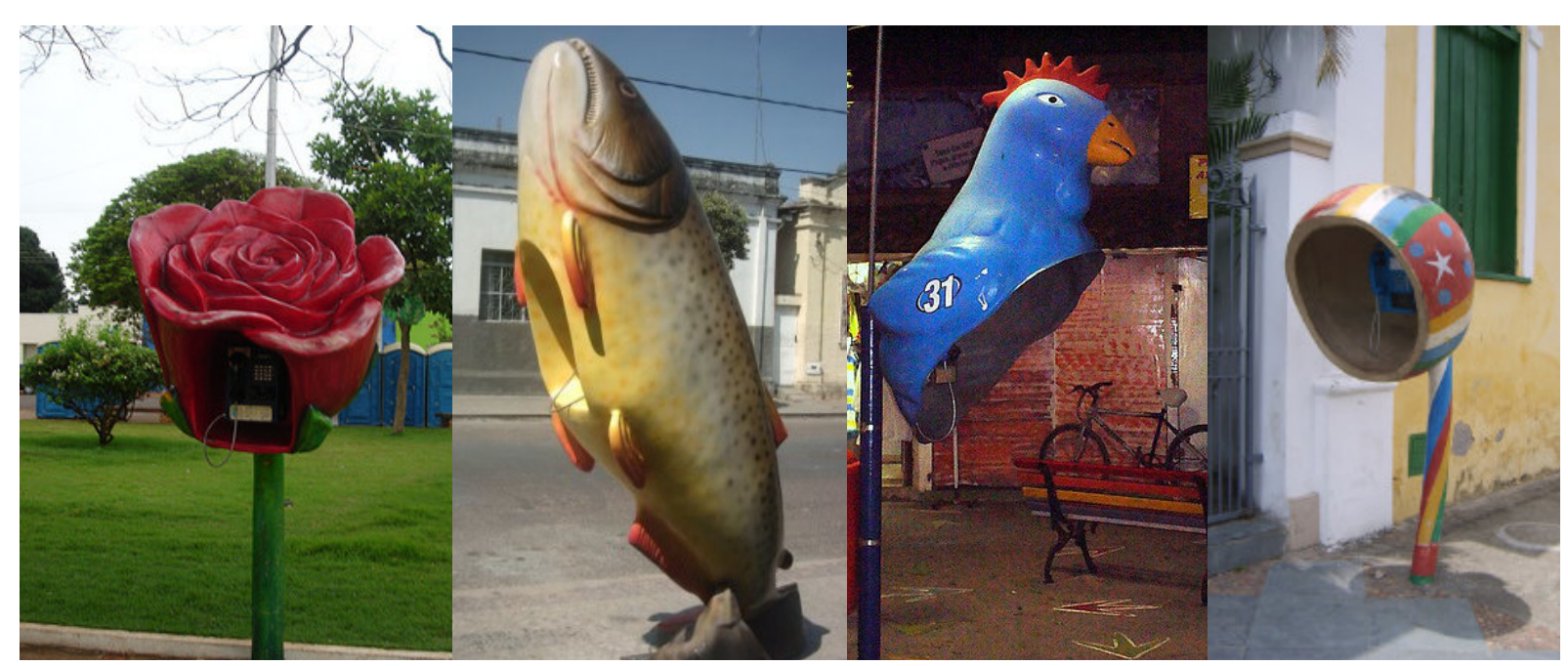

Figs 51, 52, 53, e 54. Telefones públicos figurativos em Sidrolândia, Pirapora, Porto de Galinhas e Salvador.

As reações da população à conversão de sua própria cidade em um complexo temático pode variar entre extremos. A criação de tais espaços pressupõe a aplicação de simbologia que pode não possuir identificação positiva com a região em que será inserida. Evidentemente, símbolos semelhantes podem evocar múltiplas interpretações e reações, de acordo com a história e cultura de cada local. Assim, a experiência de "tematizar" uma cidade pode tanto ser abraçada pela população por atrair visibilidade para a cultura local, fortalecer a identidade e incrementar o turismo, atraindo divisas, como pode ser totalmente rechaçada, quando o tema eleito não for condizente com o conceito de identidade local dos moradores.

A hipótese aparentemente mais provável é de que no caso de Orlando, por exemplo, tenha havido maior resistência à implantação da temática do que em casos como Lynchburg, Colbourne ou Salvador. Isto porque, mesmo que todas as temáticas tenham sido construídas em algum momento, estas populações já possuíam o vínculo estabelecido com o tema no momento inicial de sua exploração alegórica. No primeiro caso, é possível que a inclusão do tema tenha sido inicialmente rejeitada pelos habitantes locais, ou mesmo que ainda o seja. Entretanto, devemos levantar a hipótese de que gerações mais 
27. BOTTON (2007) p.96.

recentes, que convivem com o tema explorado desde "sempre" talvez entendam a temática como algo inerente à sua cidade. É preciso questionar até que ponto esta associação de um tema à paisagem urbana é realmente desprezada pela população ou se pode, com o tempo, ser consolidada e absorvida como um elemento formador da identidade local.

É provável que os moradores se oponham, inicialmente, à conversão de sua cidade em espaço temático, mas é igualmente provável que novas gerações encarem sua cidade com bastante naturalidade. Conforme afirma Botton: "A passagem de algumas gerações nos permite olhar para objetos e construções sem os preconceitos que entravam todas as eras." ${ }^{27}$

Podemos, ainda, trabalhar com a hipótese de que esta aceitação diverge do morador para o visitante - afinal, as impressões de quem pertence a uma paisagem e de quem a visita ou imagina serão, provavelmente, distintas. É possível que os símbolos e temas se tornem presentes no imaginário do turista mais imediatamente que no da comunidade local. Por serem divulgados como atrativos, os temas podem tornar-se elementos-chave no entendimento da identidade de um local pelo turista. Assim, ao questionarmos a aceitação e permanência do temático como referência identitária, podemos relacionar variáveis que influenciam em uma maior ou menor possibilidade de consolidação deste referencial, dentre elas o uso de um tema previamente conhecido pela população local e a maneira como suas características se revelam. Do mesmo modo, pensando em cidades que objetivam o turismo, a proximidade do tema com o público alvo constitui variável de influência em sua aceitação pelos freqüentadores eventuais.

Além disso, parece que não apenas o tema, mas a configuração formal dos objetos que o exploram também interfere em seu sucesso e reconhecimento. Desta forma, colocam-se como variáveis neste sucesso, além do aspecto estético, os aspectos funcionais, embora levante-se a hipótese bastante provável de que tais elementos funcionam como atrativos mais por despertarem curiosidade que por proporcionarem alguma espécie de fruição estética.

Concluímos que podemos avaliar sob diferentes aspectos a utilização de conjuntos ou elementos simbólicos ceno- 
gráficos como formadores, direcionadores ou evidenciadores de identidades locais. Se o fenômeno é recorrente, será fundamental qualificar a importância destes elementos para as regiões que os utilizam e seus visitantes. Afinal, se tais manifestações encontram, com tamanha freqüência, lugar na cena arquitetônica contemporânea, devem ser teorizadas e avaliadas como objeto de estudo para que se possa, no futuro, analisar criticamente seu papel neste momento histórico. 


\section{Capítulo 3 O tema no espaço urbano}

\begin{abstract}
“(...) a Holanda é tão completamente manufaturada quanto a Disneylândia! Não existe um único metro quadrado de terra no pais que não tenha sido aterrado ou, de certa forma, transportado, modificado e tratado para parecer como se sempre estivesse estado lá."1
\end{abstract}

James H. Gilmore e B. Joseph Pine II
1. GILMORE e PINE II (2008) p.100.
Conforme vimos, desde meados do século passado a arquitetura temática teve sua difusão ampliada, tornando-se presença praticamente obrigatória em espaços voltados para o comércio ou entretenimento. A incidência de espaços temáticos que se transformam em verdadeiras cidades, como o complexo Walt Disney World, foi crescente durante as últimas décadas. No entanto, hoje pode-se inclusive observar o processo inverso; cidades que se tornam imensos complexos temáticos. Especialmente nos Estados Unidos, já se configuram a própria cidade de Orlando e, principalmente, Las Vegas, além de inúmeras pequenas cidades que exploram o turismo baseado em determinado tema.

Poderíamos, portanto, falar não mais apenas em Espaços Temáticos, mas em Cidades Temáticas, para as quais identificamos ocorrências distintas. Este capítulo busca discutir que aspectos do temático permeiam a construção do espaço urbano em algumas circunstâncias especiais. A primeira, mais subjetiva, consiste na aplicação de temas, ou estilos impostos, em cidades inteiras, como forma de consolidação identitária e afirmação de poder, por motivações diversas. Casos como estes são encontrados ao longo de toda a história, sendo analisados aqui os exemplos de Chichen Itzá, Washington, Brasília e das cidades barrocas francesas. Nestas situações, nem o tema, nem o propósito comercial estão assumidos, portanto não se trata do modelo temático como estudamos, mas de um precedente fundamental para sua existência.

$\mathrm{Na}$ segunda ocorrência, ainda que não haja a intenção de transformar a cidade em um local temático, o acúmulo de atrações temáticas acaba por identificar a cidade com o mo- 
delo. Neste caso, não encontraremos um tema único e sim uma série de atrações com temáticas variadas que, sobrepostas, fazem com que se enxergue a cidade como um conjunto temático. Serão analisados os casos emblemáticos de Orlando e Las Vegas, nos Estados Unidos.

Em seguida, tratamos de situação contemporânea e assumidamente temática, que consiste na exploração alegórica de locais históricos, convertidos em supostas realidades nunca ocorridas. Atualmente, observa-se que tal procedimento vem se estendendo, inclusive, ao Patrimônio Histórico e Cultural. Seja sob a forma da onipresente marca do patrocinador, seja sob a incorporação espetacular ao espaço, é possível identificar elementos temáticos em espaços cujo valor seria, primordialmente, cultural. A estes locais de especial relevância histórico-cultural é agregado, através do tema, um novo valor simbólico.

Finalmente, será avaliado um modelo recente, das comunidades suburbanas planejadas norte-americanas, em que o tema, ainda que não externo à esfera da arquitetura, está presente desde o início da concepção do espaço. Nestes locais não encontramos uma temática figurativa e narrativa clássica, mas referências a uma suposta época em que a vida seria melhor e é esta vida que se vende aos novos moradores.

3.1 Será fácil perceber que, no contexto contemporâneo, o Poder e Tema temático se estende a museus e sítios históricos, com a aplicação de alegorias a cidades historicamente não temáticas. Entretanto, podemos mostrar que, mesmo antes da exploração comercial do temático, encontramos uma série de cidades que, de certa forma, tiveram suas concepções orientadas por temáticas diversas, objetivando não a consolidação do ponto de venda, mas a consolidação de poder do governante da época. Seja construindo ilusões que convencessem os súditos, seja transmitindo mensagens subliminares de progresso, a arquitetura foi explorada como recurso de construção identitária local. Se pensássemos o conceito de temático como um tema aplicado a uma maior quantidade possível de detalhes, de forma que o visitante se desvincule de tudo o que existe fora do local em que está, poderíamos entender os casos citados como 
Cidades Temáticas. Porém, como tratamos do temático como conseqüência da exploração comercial, entendemos estas cidades como antecessores históricos dos Espaços Temáticos no sentido contemporâneo, essencialmente comercial.

Nas ruínas Maias de Chichen Itzá, na península de Yucatan, no México, identificamos o fenômeno contemporâneo da exploração alegórica do sítio histórico, mas também podemos pensar que, originalmente, a cidade foi concebida segundo certas características temáticas. No local, é realizado, atualmente, um show de luzes e sons que conta a história da civilização pré-colombiana através de projeções e iluminação especial nas ruínas. Na Pirâmide de Kukulcán, em torno da qual se desenvolvia a cidade, a insolação, duas vezes por ano, projeta uma sombra que nos dá a impressão de uma cobra que se movimenta em direção ao solo. Com o show de luzes, este fenômeno passa a ser reproduzido artificialmente quantas vezes forem necessárias. O que originalmente fora um rito religioso - os Maias consideravam que neste momento os Deuses, através da serpente, desciam para fertilizar o solo - torna-se uma exibição espetacular. Hoje existem duas modalidades de ingresso para visitar as ruínas: o ingresso diurno, que permite visitação de toda a área aberta aos turistas, e o combinado, que inclui, ao fim do dia, a apresentação do show de som e luz.

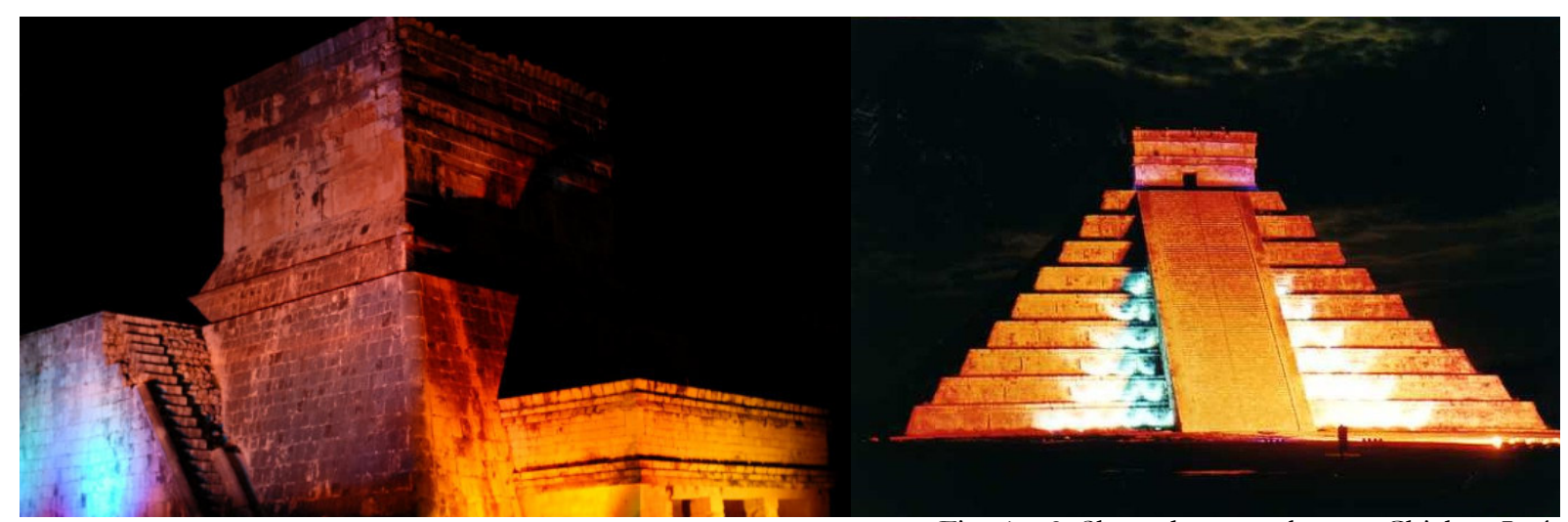

Figs 1 e 2. Show de som e luz em Chichen Itzá.

Poderíamos dizer que, ainda que se trate de um ritual cuja origem é essencialmente espetacular, pois o povo Maia se reunia em frente à pirâmide para assistir ao fenômeno da fertilização, é evidente que há uma distinção entre as duas facetas do espetáculo. Hoje, se por um lado há o propósito de retratar a cultura Maia, por outro há uma inversão dos valo- 
res presentes no ritual, através deste acréscimo de elementos espetaculares, incompatíveis com a identidade dos povos originais.

Sob este enfoque, o local poderia ser tratado como um sítio histórico explorado através do temático, caso que será analisado mais à frente. Entretanto, indo além, podemos entender que a própria concepção da cidade segue uma ótica temática, já que toda a estrutura foi pensada para envolver o povo Maia na fantasia de que o governante estava vinculado aos deuses locais. Como os parques temáticos contemporâneos, a cidade pré-colombiana contava com efeitos especiais que intensificavam a inserção no mundo fantástico apresentado. A aglomeração do povo aos pés da pirâmide para aplaudir o governante, saudando-o com palmas, era imediatamente respondida com o som de pássaros e cobras, obtido graças a efeitos acústicos cuidadosamente planejados. Tais efeitos confirmavam para a população a crença de que a presença do governante coincidia com a presença dos deuses, reafirmando seu poder. Seguindo a mesma lógica, o já citado efeito em que a sombra da cobra descia a pirâmide para fertilizar o solo é alcançado devido à implantação precisa da edificação, obtendo justamente nos equinócios de primavera e outono a sombra da serpente movimentando-se em direção ao solo, conforme 2. AROCHI (1992) o sol se põe. ${ }^{2}$ Em suma, efeitos espetaculares eram aproveitados, se não para fins comerciais, certamente para fins de consolidação política.

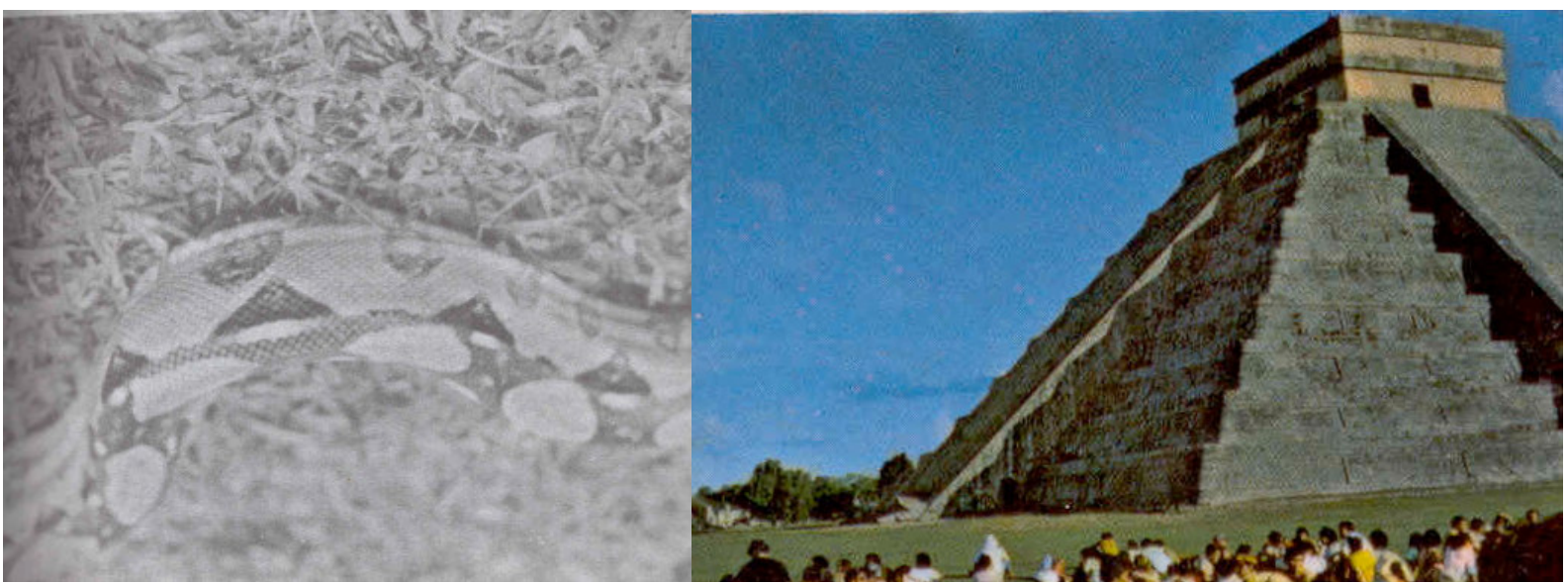

Figs 3 e 4. Serpente com desenho triangular e gerada pela sombra em Chichen Itzá. Avançando no tempo, pode-se citar o exemplo das cidades barrocas francesas e sua chamada 'Arquitetura de Festa', conceito definido por Oechslin e Buschow ${ }^{3}$, fazendo referên- 


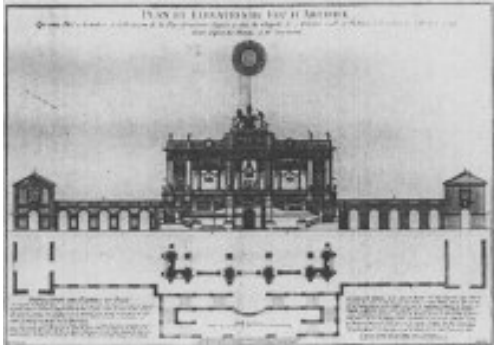

Fig 5. Projeto para execução e queima de fogos em comemoração ao tratado de Paz de Aix-laChapelle, 1748

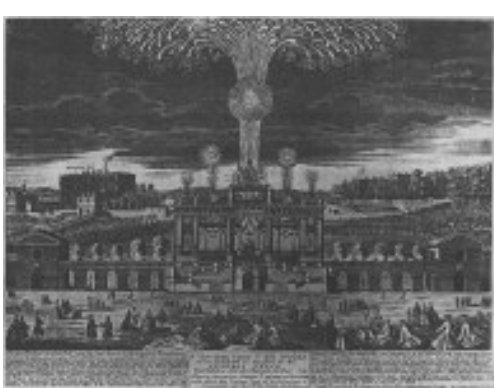

Fig 6. Representação de Giovanni Niccolò para comemoração pelo tratado de paz de Aix-la-Chapelle. cia à ornamentação dada à cidade em ocasiões especiais, para celebrar eventos e ressaltar o poder do governante que promovia a festa. Novamente podemos mostrar como a arquitetura temática assumida e comercial, embora possibilitada por fatores sócio-econômicos consolidados no último século, traz reflexos da exploração arquitetônica alegórica anterior, no caso a que foi difundida durante os séculos XV e XVI. A explosão, hoje, não apenas do uso da arquitetura temática, mas do tratamento cenográfico dado à ornamentação de festas, cerimônias, stands promocionais e design de vitrines, por exemplo, leva a crer que um interesse crescente relaciona a arquitetura e design ao "mise en scène", à festa. As funções características dessa arquitetura do passado eram e são empregadas quando há a necessidade de simbolizar algo, ou de redesenhar um espaço para ocasiões específicas.

Desde os séculos XV e XVI, as comemorações oficiais - conquistas, coroações, aniversários reais, etc - eram acompanhadas de alguma ornamentação, que chegava a incluir a construção de fachadas temporárias e intervenções no interior dos ambientes. Ainda que os elementos apresentados possam diferir dependendo da espécie da celebração, é possível tratar das generalidades das festas, colocando-as como um único fenômeno. Pouco a pouco, os elementos arquitetônicos tornaram-se fundamentais nas cerimônias. Sua importância deixa de ser apenas decorativa quando a Arquitetura de Festa amplia seu repertório, apresentando soluções para os mais diversos objetivos. A arquitetura passa, então, a ser utilizada como representação de idéias, pois a ornamentação funciona, por exemplo, como reflexo da grandiosidade de uma cerimônia. Portanto, o valor da Arquitetura de Festa cresce conforme ganha importância o papel do projeto realizado previamente, ou seja, conforme aparece a participação do profissional responsável pelo projeto da ornamentação.

Porém, se no momento em que surge a ornamentação festiva cresce a presença do projeto e do profissional, o produto final não é reflexo da obra do idealizador. A figura do artista ainda não está delineada nesta época. Ao contrário, na Arquitetura Temática a atração não mais se restringe à celebração, mas o aspecto espetacular pode promover a assinatura 
5. DUNLOP (1996) pp. 162-165. mínimo possível. ${ }^{5}$

do artista. Em muitos casos, arquitetos se recusam a aceitar o projeto temático por considerar inviável imprimir sua assinatura em um ambiente que, mesmo antes de sua concepção, já tem um tema pré-determinado a ser seguido. Como vimos, no projeto da Disneyland Paris, por exemplo, coube ao arquiteto Frank Gehry o setor que foi então chamado de "entertainment 4. Ver Capítulo 2.2 center" - uma espécie de rua comercial que serve como elemento de ligação entre o parque e os hotéis do complexo. Relutante em projetar um espaço temático, o arquiteto optou pelas formas abstratas e fluidas características de seu repertório, evocando sempre o caráter festivo, mas restringindo os elementos de referência direta - personagens e cartoons - ao

Assim, apesar de se aproximar da arquitetura de festa no sentido alegórico, o que aqui é entendido por Arquitetura Temática diferencia-se por acrescentar ao ambiente construído temas externos à esfera da arte e arquitetura. Portanto, nos Espaços Temáticos, o tema não passa, necessariamente, pela reprodução de um estilo arquitetônico ou artístico consagrado anteriormente. Tampouco estamos tratando simplesmente do acréscimo de elementos compositivos com função exclusivamente plástica. Nos ambientes temáticos, estes elementos devem remeter ao assunto explorado, temáticas tão distintas quanto desenhos animados e fábulas infantis, cinema, música, e até mesmo personalidades famosas.

Já no momento em que se destaca a Arquitetura de Festa, observa-se que o uso de adornos como forma de embelezar a cidade se dá a fim de transmitir o caráter moderno do local. Desde então, uma cidade em que figuram tais alegorias aplicadas ao projeto tem representada sua modernidade. A colocação de esculturas, arcos de triunfo e inúmeras outras formas comemorativas tornou-se símbolo de prosperidade. A partir do surgimento da arquitetura temática como se conhece hoje, na década de sessenta, pode-se inferir que é configurada uma nova maneira de atingir objetivo semelhante. A inclusão do tema em um estabelecimento o coloca como algo moderno, atual e potencialmente bem sucedido.

Se, por um lado, tanto a Arquitetura de Festa como a Temática podem ser caracterizadas por refletir a moderni- 


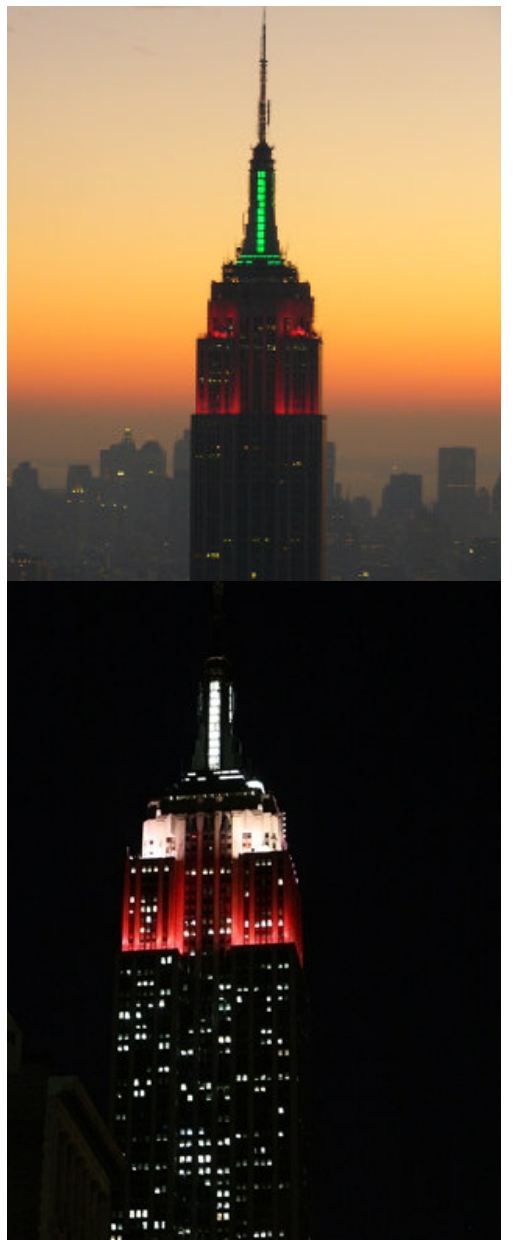

Figs 7 e 8. Empire State Building iluminado para celebrar o Natal e o Valentine's Day. dade, por outro deve-se ressaltar que a primeira o faz com acesso irrestrito. Antes de mais nada, a Arquitetura de Festa constitui um espetáculo público, uma forma de representar a cidade fazendo com que o povo se reconheça como parte integrante, estabelecendo uma identidade para a comunidade. Hoje, a Arquitetura Temática aplicada a espaços comerciais e, portanto, privados, torna-se, ao contrário, símbolo da globalização. O uso de temas alheios à cultura local faz com que, em muitos casos, a temática adotada não represente a identidade da cidade, e sim um elemento externo sendo inserido em seu contexto social. Deste modo, a Arquitetura de Festa utiliza e renova o espaço público para realizar o evento, enquanto a Arquitetura Temática recria espaços idealizados para abrigar o evento.

O uso cenográfico da iluminação é outra característica freqüentemente encontrada na Arquitetura Temática e, possivelmente, herdada da Arquitetura de Festa. Nesta época, o espaço festivo configurava-se com presença marcante de fogos de artifício, um dos principais elementos da cerimônia. Não se tratava, porém, de um espetáculo realizado aleatoriamente. Há evidências de que a queima de fogos se dava seguindo um projeto prévio, de modo que podemos considerar que começavam a se definir os primórdios do lightning design. Um profissional recebia a responsabilidade de diagramar a explosão de fogos, bem como de coordenar sua execução. Da mesma forma, os Espaços Temáticos de hoje têm em sua configuração, além do projeto funcional de iluminação, a presença de lasers e fogos de artifício, de acordo com a grandeza do estabelecimento. Entre os grandes parques temáticos, os shows que incluem a queima de fogos de artifício e lasers ao fim de cada dia tornaram-se ritual praticamente obrigatório, presente em todos os parques dos complexos Disney e Universal Studios, os maiores do gênero. Do mesmo modo, os grandes cassinos temáticos atraem público para o jogo apresentando shows de luzes e, mesmo em núcleos temáticos de pequeno porte, a iluminação assume papel fundamental. Além disso, a iluminação aparece em projetos temáticos temporários, quando o objetivo é reconfigurar um espaço por período determinado. O famoso Empire State Building, em Nova York, por exemplo, recebe 
iluminação diferenciada a fim de representar a comemoração de datas especiais - Natal, Ano Novo, Thanksgiving, etc. No Rio de Janeiro, a Estação Central do Brasil já foi iluminada com as cores verde e rosa, em celebração à famosa Escola de Samba local, Estação Primeira de Mangueira. Recentemente, em São Paulo, uma iluminação especial coloriu de cor de rosa o hotel Unique, projeto de Ruy Ohtake, em comemoração ao lançamento de uma marca de champagne rosé.

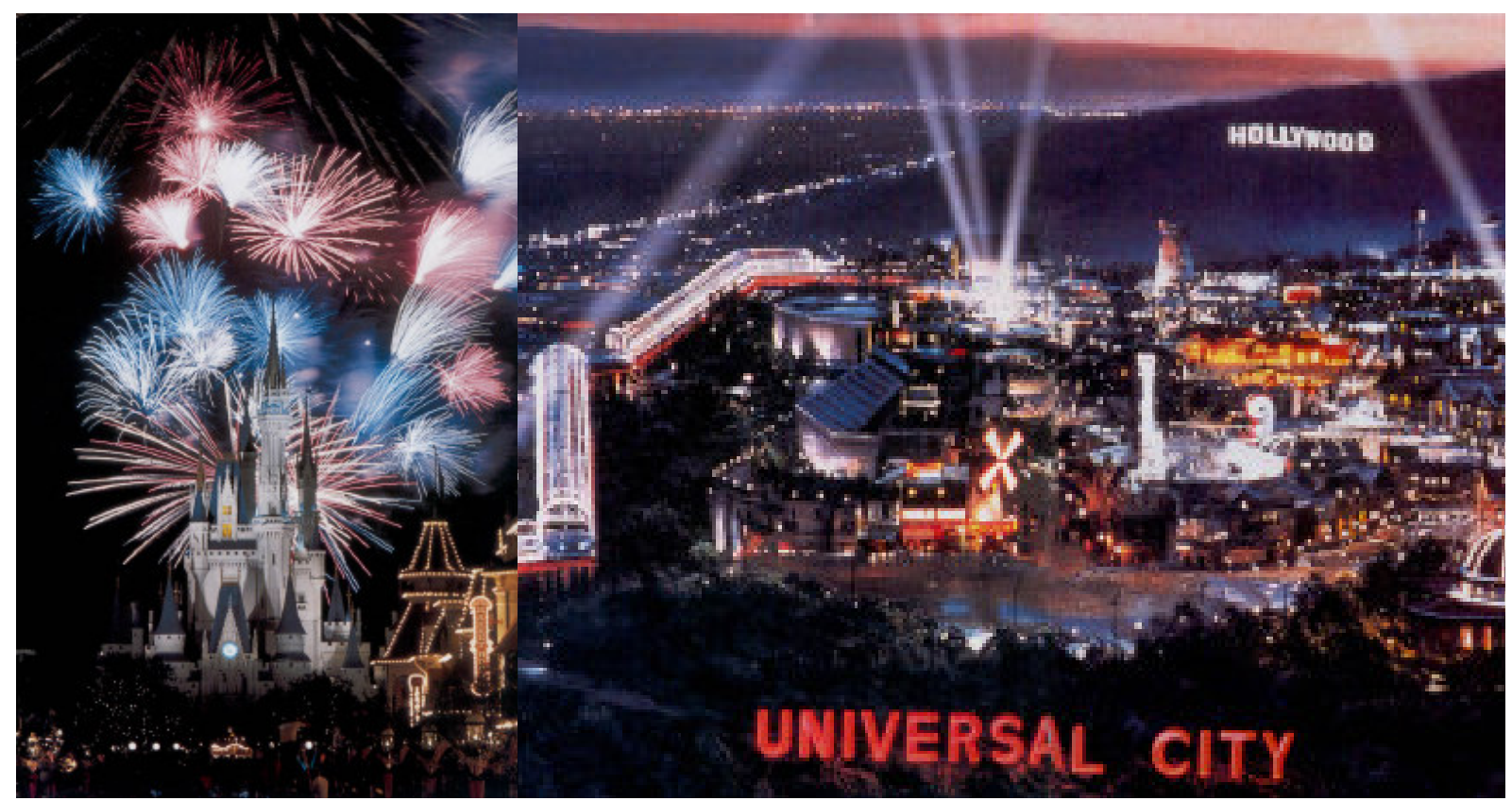

Figs 9 e 10. Queima de fogos no Magic Kingdom, em Walt Disney World e show de lasers na Univeral Studios Hollywood.

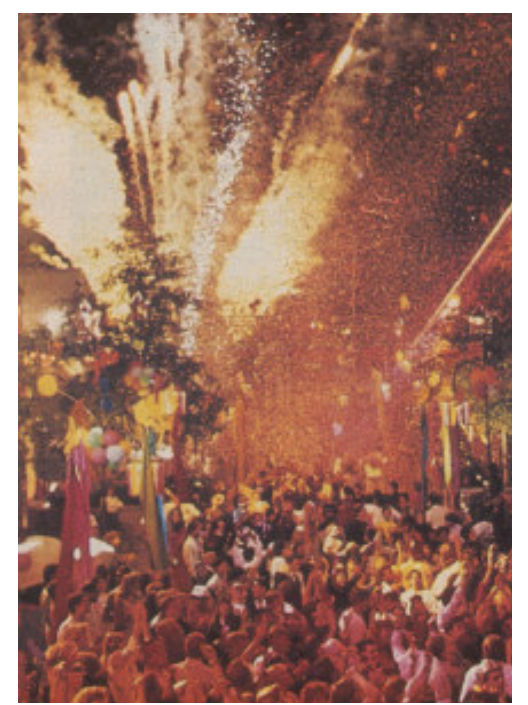

Fig 11. Queima de fogos no Pleasure Island, em Walt Disney World.
A Arquitetura de Festa tornou-se campo de experimentação para o profissional, oferecendo possibilidades de inovação e concretização de idéias. No entanto, pode-se observar que, embora sejam infinitas as possibilidades formais, e, ainda que este repertório tenha sido expandido, alguns elementos pareciam adequar-se com maior facilidade ao objetivo da celebração. Nota-se que determinadas formas foram sistematicamente repetidas, situação que se manteve durante séculos. Hoje, os ambientes construídos com inspiração em certo tema exemplificam a idéia de que alguns elementos formais sofreram pequenas modificações, mantendo-se praticamente inalterados. Encontram-se nos núcleos temáticos formas clássicas -obeliscos, entradas triunfais, monumentos, arcos, chafarizes, etc - sendo que, de um modo geral, tais elementos apresentam-se como releituras ou de forma bastante semelhante à Arquitetura de Festa. No desenho de espaços te- 
máticos, a liberdade de uso de repertórios distintos pode levar o profissional responsável a não resistir à tentação de reunir em seu projeto os elementos construtivos mais grandiosos, mesmo porque o objetivo de trazer imponência é facilmente alcançado com este repertório que remete à arquitetura clássica. Assim, em sua maioria, os ambientes temáticos apresentam uma configuração bastante eclética, reunindo referências de épocas e situações diversas.

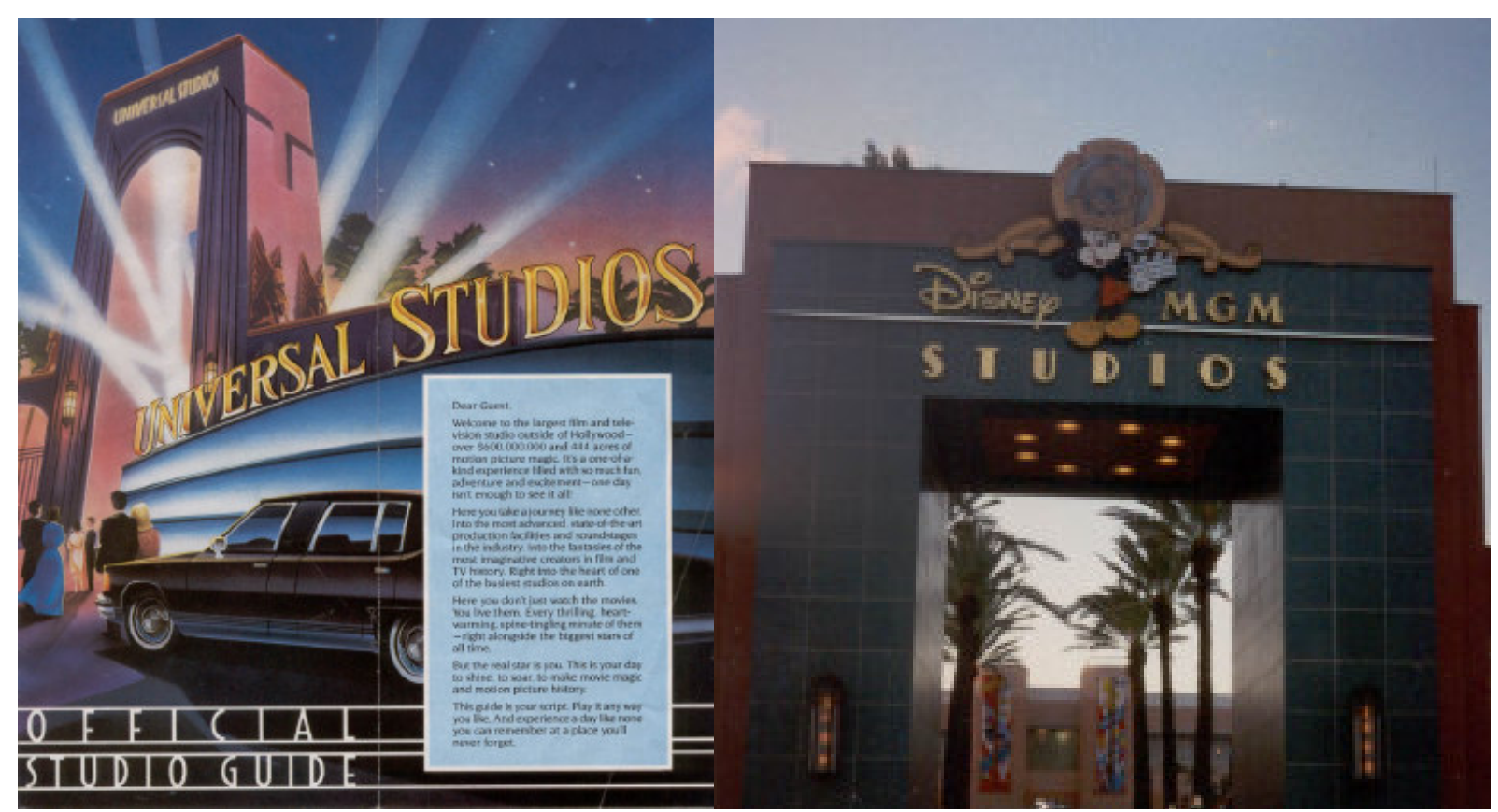

Figs 12 e 13. Arco triunfal no guia da Universal Studios e no MGM Studios, atualmente renomeado Hollywood Studios.

O arco de triunfo, usado nesta época para celebrar vitórias em batalhas, permanece no repertório atual como símbolo de grandiosidade. No Brasil encontramos um exemplo em Sobral, no Ceará, onde foi erguido, em 1953, um arco triunfal remetendo à forma clássica para celebrar a passagem pela cidade da imagem de Nossa Senhora de Fátima. ${ }^{6} \mathrm{O}$ arco de Sobral é claramente alegórico, mas encontramos referencias mais sutis como o Grande Arche de La Défense, em Paris.

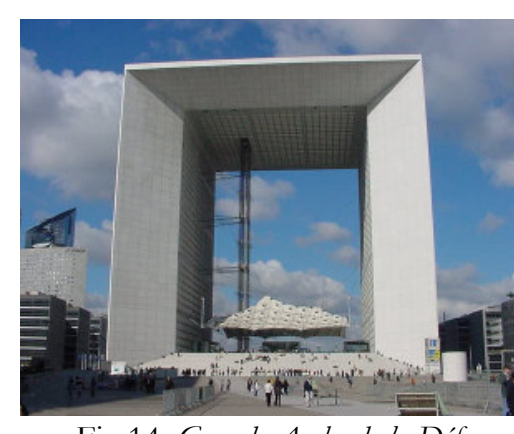

Fig 14. Grande Arche de la Défense; Embora mencione o arco triunfal, o Grande Arche possui programa diverso e adota estética contemporânea.

Uma característica bastante específica da Arquitetura de Festa é seu caráter efêmero. A maior parte do que é construído para a celebração dura o tempo necessário, o tempo da comemoração, para ser posteriormente desfeita. Quando a Arquitetura Temática é aplicada a eventos e comemorações Paris. provisórias - feiras, congressos, stands promocionais, festas, 


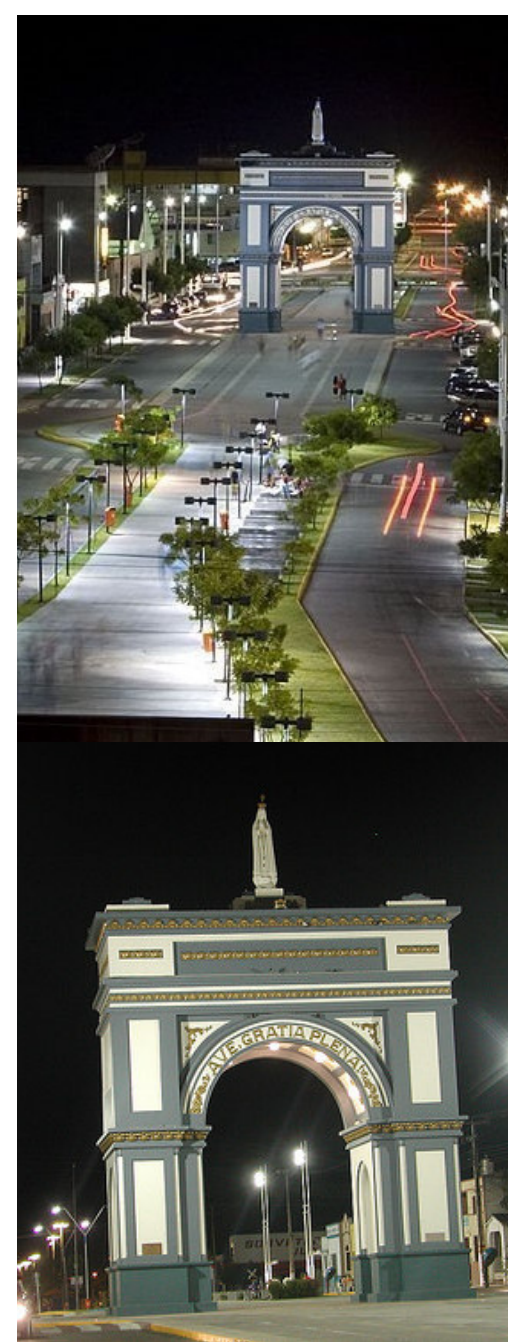

Figs 15 e 16. Arco do triunfo de Sobral; Ceará.

7. OECHSLIN e BUSCHOW (1984) p.43

Segundo o autor, em Roma, as grandes banheiras que se encontram até hoje na Praça Farnese eram utilizadas todo ano como recipiente para servir vinho nos dias de festa em homenagem a S. Pierre e S. Paul. etc - a relação estabelecida com o tempo é semelhante. Porém, embora a Arquitetura Temática seja, na maioria dos casos, desenhada para durar, alguns elementos podem determinar sua vida útil. Assim, em estabelecimentos de longa existência, provavelmente um dos fatores que, atualmente, mais influencia na escolha do tema é a previsão de sua duração. A escolha de um tema inadequado pode ocasionar espaços efêmeros, o que vem acontecendo com freqüência progressiva. Portanto, em um projeto temático, torna-se questão decisiva e, conseqüentemente, digna de estudo, a relação entre arquitetura e/ ou design e tempo. Do mesmo modo, o tema é freqüentemente usado como forma de styling, ou seja, com a intenção única de tornar mais atraentes espaços já desgastados. Nesses casos, tem-se o objetivo de prolongar o tempo de vida útil do estabelecimento, sem que se promovam mudanças estruturais. Tal fenômeno se repete de tempos em tempos, renovando o espaço de acordo com o momento vivido, assim como era feito na época da Arquitetura de Festa.

Além dos precedentes já apontados, era possível observar aspectos temáticos. A realeza costumava celebrar eventos com queima de fogos de artifício, mas, além disso, fontes eram utilizadas como recipientes para servir vinho, por exemplo, o que demonstra o aspecto fantasioso da cerimônia. Mesmo o hábito de promover, durante as festas, caça a animais selvagens remete a uma temática mitológica. ${ }^{?}$

Portanto, a Arquitetura de Festa constituiu forte influência e, mesmo, possibilitou a existência da Arquitetura Temática. Além disso, fica estabelecida uma estreita relação entre ambas, não apenas por se voltarem para o entretenimento, mas, acima de tudo, pela inspiração direta no fantástico, pela inclusão da fantasia no ambiente construído. Novamente, podemos enxergar na exploração alegórica uma afirmação de poder, já que tanto a prosperidade local quanto a aceitação do Rei pela população estavam irremediavelmente ligados à Arquitetura de Festa.

Mais recente, a configuração de Washington DC, capital dos Estados Unidos, parece também obedecer à lógica da exploração temática como instrumento para afirmação de poder. A cidade planejada tem no uso da arquitetura neoclás- 
sica, que permeia todos os monumentos e edifícios públicos, a garantia de uma imagem de solidez e confiabilidade, necessária à capital norte-americana. Em grande parte projetados por Thomas Jefferson, arquiteto e então presidente do país, os edifícios de Washington conferem unidade à capital por trazerem todos a mesma estética neoclássica, descoberta por Jefferson enquanto servia como embaixador em Paris. Não por acaso, esta mesma estética servira ao Império Napoleônico como representativa de sua grandiosidade.

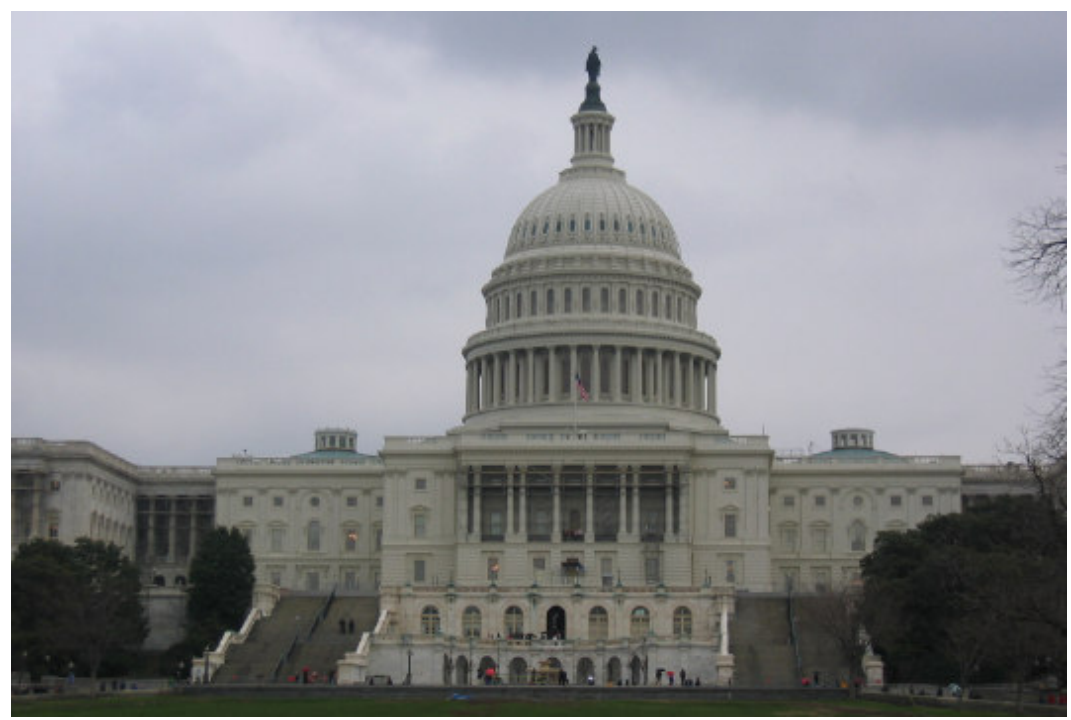

Fig 17. Capitólio; Washington.

Jefferson acreditava que a Roma republicana era o modelo a ser seguido política e socialmente pelos Estados Unidos, retomando inclusive a nomenclatura romana "senado" para o parlamento americano. ${ }^{8}$ Para abrigar o senado, foi projetado o edifício mais emblemático do neoclassicismo norteamericano, o Capitólio, logo replicado em inúmeras outras cidades. Como governador do Estado da Virgínia e, mais tarde presidente, Jefferson valorizou esta arquitetura dita nova em relação à sua antecessora, vinda da Inglaterra colonizadora, para, com isso, refletir o novo momento de independência e democracia que, por sua vez, demandava a construção de uma série de novas edificações institucionais. Portanto, todos os edifícios e monumentos erguidos durante o período receberam a arquitetura neoclássica que hoje simboliza tão bem a cidade. Havia, então um consenso acerca do aspecto formal dos edifícios, conforme aponta Alain de Botton:

"Tão forte era esse consenso que cidades in- 
teiras adquiriram uma unidade de estilo que se estendia por uma série de praças e avenidas.

Uma linguagem estética datando de antes do

Templo de Apolo, em Delfos, acabou enfeitando as casas das famílias de contadores em

9. BOTTON (2007) p.32. Edimburgo e advogados na Filadélfia."9

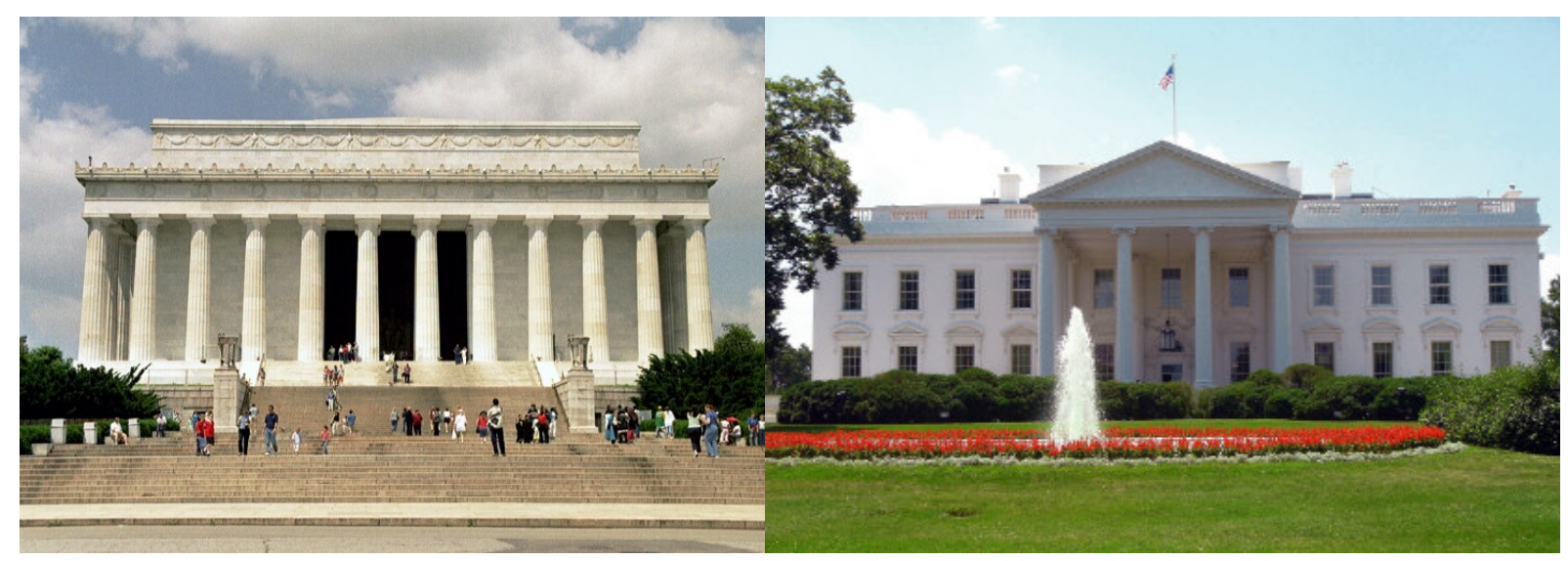

Figs 18 e 19. Lincoln Memorial e Casa Branca; Washington.

Assim como Washington, Brasília foi uma cidade planejada e, como tal, teve seu projeto orientado por uma identidade que se almejava construir. Temos, portanto, mais de um século mais tarde, uma situação análoga, desta vez utilizando a arquitetura modernista, na época representativa de progresso e tecnologia.

Inaugurada em 21 de abril de 1960, a nova capital brasileira era compatível com a política desenvolvimentista do então presidente Juscelino Kubitschek, baseada no crescimento da indústria apoiado na entrada de capital estrangeiro no país. A construção da cidade no planalto árido e desocupado refletia a proposta de desenvolver o país como um todo, assim sua localização central trazia um forte simbolismo. A mesma imagem transparece na estética modernista adotada na concepção arquitetônica e urbanística de Brasília, trazendo consigo uma demonstração de progresso e desenvolvimento. Era esta justamente a identidade que se desejava transmitir, associando a nova capital à indústria nacional, sobretudo a automobilística, que teve impulso no mesmo momento, configurando-se como símbolo do crescimento industrial proposto.

Portanto, a grandiosidade a ser refletida na nova capi10. BRUAND (2002) p.183. tal dependia, segundo Yves Bruand ${ }^{10}$, de um projeto centralizador que unificasse toda a concepção, bem como de uma 
linguagem forte, razão pela qual Oscar Niemeyer foi convidado para responsabilizar-se pelo projeto. Em função do curto prazo de cinco anos para concepção e execução das obras, não foi aberta concorrência, mas o plano urbanístico de Lúcio Costa, totalmente compatível com a obra de Niemeyer, foi selecionado por concurso. A implantação, seguindo um eixo monumental, associada à própria monumentalidade dos edifícios governamentais, reafirma o poder do governo. Por sua vez, a configuração em super quadras e setores valoriza a utilização do automóvel, símbolo do desenvolvimento da indústria local, além de representar modernidade, desde o crescimento da arquitetura modernista corbusiana.

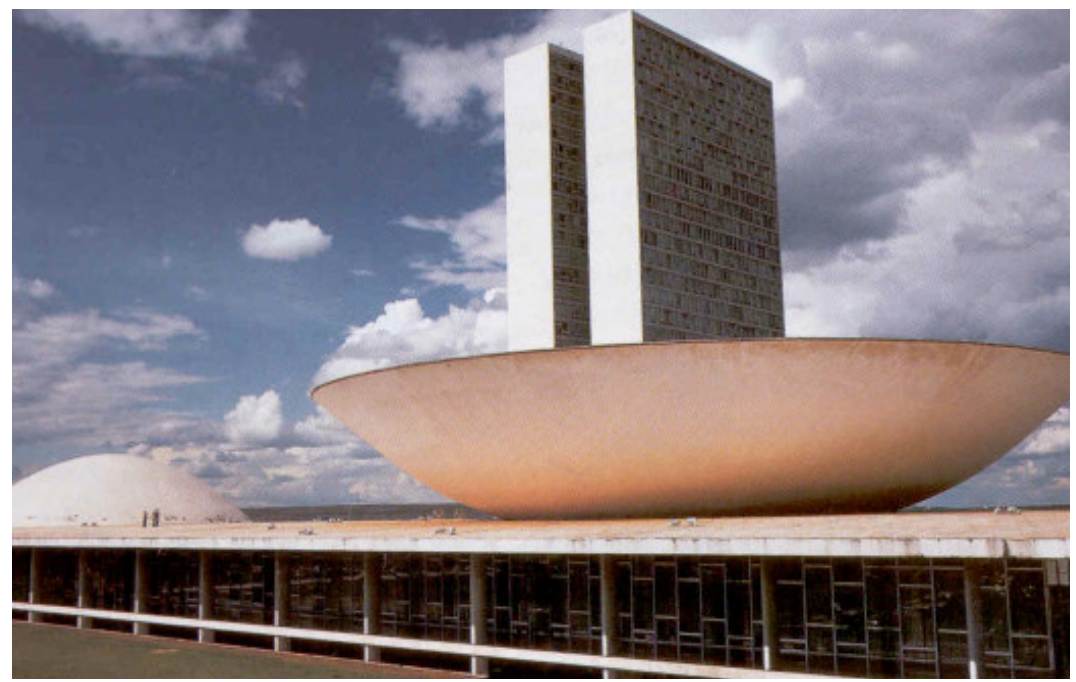

Fig 20. Palácio do Congresso, de Oscar Niemeyer; Brasília.

11. Entrevista concedida ao documentário JK.doc (exibido em 19 de novembro de 2007 no canal GNT)

Brasília apresenta, então, elementos característicos de uma concepção temática, ainda que não alegórica e figurativa, pois todo o projeto foi orientado para seguir determinada estética que transmitisse a mensagem desejada, no caso de modernidade, tecnologia e desenvolvimento. Maria Elisa Costa, filha de Lúcio Costa e arquiteta, chegou a afirmar que a proposta do plano era criar uma capital com cara de capital. ${ }^{11}$ De botton descreve bem a intenção do projeto:

\footnotetext{
"Brasília não tinha a intenção de simbolizar uma realidade nacional existente, mas, sim, a de criar uma nova realidade. Esperava-se que, com suas largas avenidas e ondulantes prédios de aço e concreto, ela ajudasse a apagar a herança de colonialismo do Brasil, assim como o caos e a pobreza de suas cidades costeiras. Brasília daria origem à modernidade que sim-
} 
bolizava. Ela criaria um pais à sua própria imagem."12

Portanto, vimos que mesmo sem o uso figurativo e assumido de um tema, encontramos exemplos de cidades que, como demonstração de poder, fizeram uso de elementos característicos da exploração temática em seus espaços urbanos bem antes da difusão do temático comercial. Se essas precursoras do temático traziam a arquitetura como símbolo do poder político, pode-se dizer que enxerga-se na exploração temática contemporânea um deslocamento de poder, em que a alegoria se coloca a serviço do corporativo, algo bastante emblemático de nossa época.

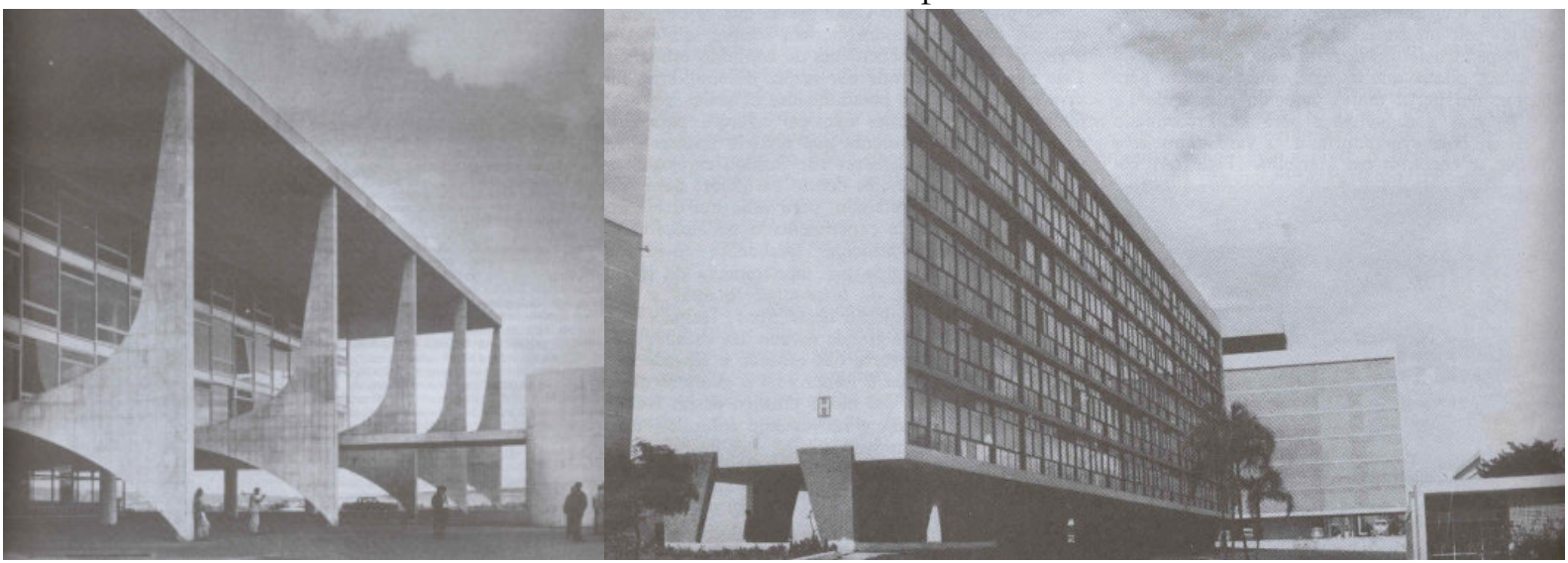

Figs 21 e 22. Palácio do Planalto e bloco residencial, de Oscar Niemeyer; Brasília.

Os exemplos de Chichen Itzá, das cidades francesas, Por acúmulo Brasília e Washington, evidentemente, diferem dos que exploram o tema com características mais figurativas e assumidas, mas são especiais por receberem uma linguagem estética deliberadamente uniforme, quase temática. Certas cidades, ao contrário, associam-se ao temático não pela aplicação generalizada de um mesmo tema, e sim pelo acúmulo e sobreposição de estabelecimentos temáticos de inspirações diversas. Orlando e Las Vegas, nos Estados Unidos, são com certeza os dois exemplos mais característicos desta expansão temática.

Cabe aqui retomar o Kitsch analisado por Abraham Moles $^{13}$, estabelecendo uma analogia com a observação de Ver Capítulo 1.2 que podemos identificar o Kitsch por agrupamentos de objetos. Para Moles, em certos casos a tipologia kitsch pode ser identificada não pelo objeto em si, mas pela relação estabelecida dentro de um agrupamento de objetos. Haveria, então, 
Adults \$24.99 $~ K i d s \$ 14.99$ After Discount Dinmer \& Show

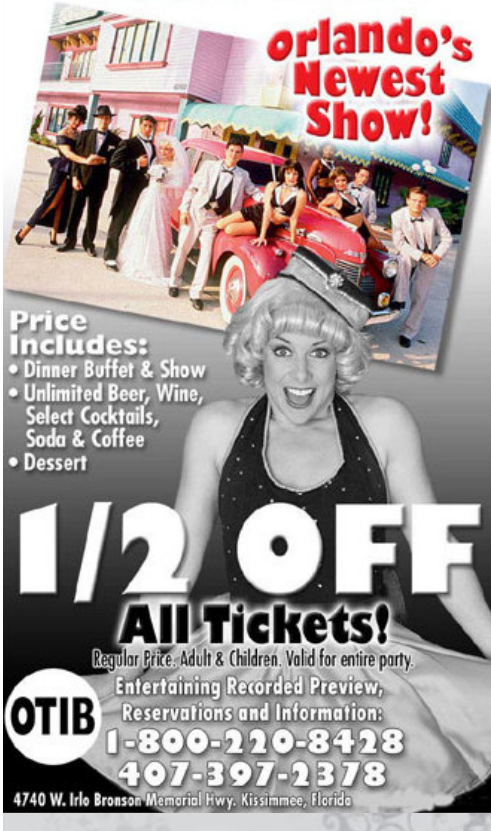

\section{Two for One!}

\section{Arabian Nights}

The World's Greatest Show.. On Horses!

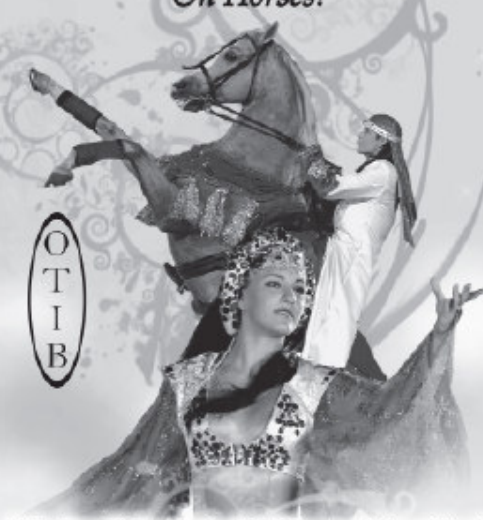

We Are Orlando's \#1 Dinner Attraction We Will Win Your Heart

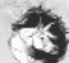

Information \& Reservations

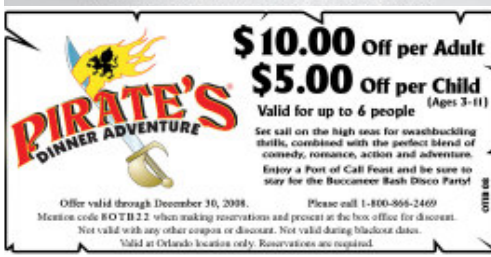

Figs 23, 24 e 25. Cupons promocionais para Capone's dinners show, Arabian Nigths e Pirate's dinner adventure, dinner shows em Orlando. agrupamentos caracterizados por quatro possibilidades. Podem seguir o "critério de empilhamento", em que o acúmulo é tal que os espaços de influência dos objetos inicialmente se tocam, e logo se sobrepõem. Podem ser "caracterizados pela heterogeneidade", caso em que os objetos acumulados não possuem qualquer relação direta entre si. Outra possibilidade é o "critério de antifuncionalidade", quando a série de objetos, ainda que relacionados entre si, não obedece a critério utilitário. E, finalmente o agrupamento pode seguir um "critério de autenticidade Kitsch, ou de sedimentação", quando os objetos são lentamente acumulados sem qualquer preocupação com o conjunto.

Talvez possamos tratar regiões em que prevalece o acúmulo de edificações temáticas como uma recriação em maior escala do modelo de Moles. Todos os critérios mencionados anteriormente podem ser identificados nos exemplos a serem analisados. Os Espaços Temáticos proliferaram de forma que realmente suas áreas de influência ficaram sobrepostas, além de não haver qualquer preocupação com o conjunto ou com uma potencial relação de funcionalidade entre as construções, pois estamos tratando de estabelecimentos autônomos. Como cada local recebe um tema diferente, podemos também identificar a heterogeneidade do conjunto. Teríamos, portanto, regiões em que o aspecto temático, ainda que presente em inúmeros estabelecimentos isolados, sobressai pela relação que se configura entre eles.

Nos arredores de Orlando, o fenômeno explica-se pela presença do Walt Disney World, pois o pólo atrativo para turistas do mundo inteiro gerou inúmeros outros empreendimentos temáticos que aproveitam este alto fluxo de público - parques, dinner shows, lojas, bares - a ponto de podermos perceber a região como um grande conjunto de espaços temáticos justapostos.

Quando a Disney comprou o terreno na Flórida para a construção do complexo, a Disneyland, na Califórina, já era um grande sucesso. Vários Estados ofereceram vantagens, tentando atrair o novo empreendimento do grupo e, durante algum tempo, houve certo suspense, com bastante especulação e vários jornalistas tentando obter o "furo de reportagem" de di- 
14. DUNLOP (1996) pp.45-46. sem divulgação do comprador. ${ }^{14}$

O parque original, a Disneyland, cujo terreno era de proporções bem menores do que a área arrematada na Flórida, fora, rapidamente, cercado por atrações menores, hotéis e cadeias de fast-food. Esse tipo de empreendimento, chamado internamente de parasita, afetava a proposta de escapismo em relação a toda realidade externa ao parque. Com o novo complexo, Walt Disney quis evitar o que acontecera em Los Angeles, por isso o objetivo de, desta vez, adquirir a maior extensão de terra possível, um total de cerca de 111 quilômetros quadrados, preservando os arredores das atrações e permitindo estrito controle sobre o conjunto.

Para se ter uma idéia das dimensões do complexo Disney 15. FJELLMAN (1992) p.394. World, Stephen Fjellman ${ }^{15}$ informa que, desde que adentra os limites do complexo até chegar ao Magic Kingdom, o mais antigo dos parques, o visitante deve dirigir 4,5 milhas até o estacionamento, tomar um bonde até a bilheteria e, ainda, um monotrilho ou ferry boat até a entrada. Portanto, os parques estão totalmente isolados e foi definitivamente configurado um percurso de imersão em que não cabem referências externas à temática do complexo.

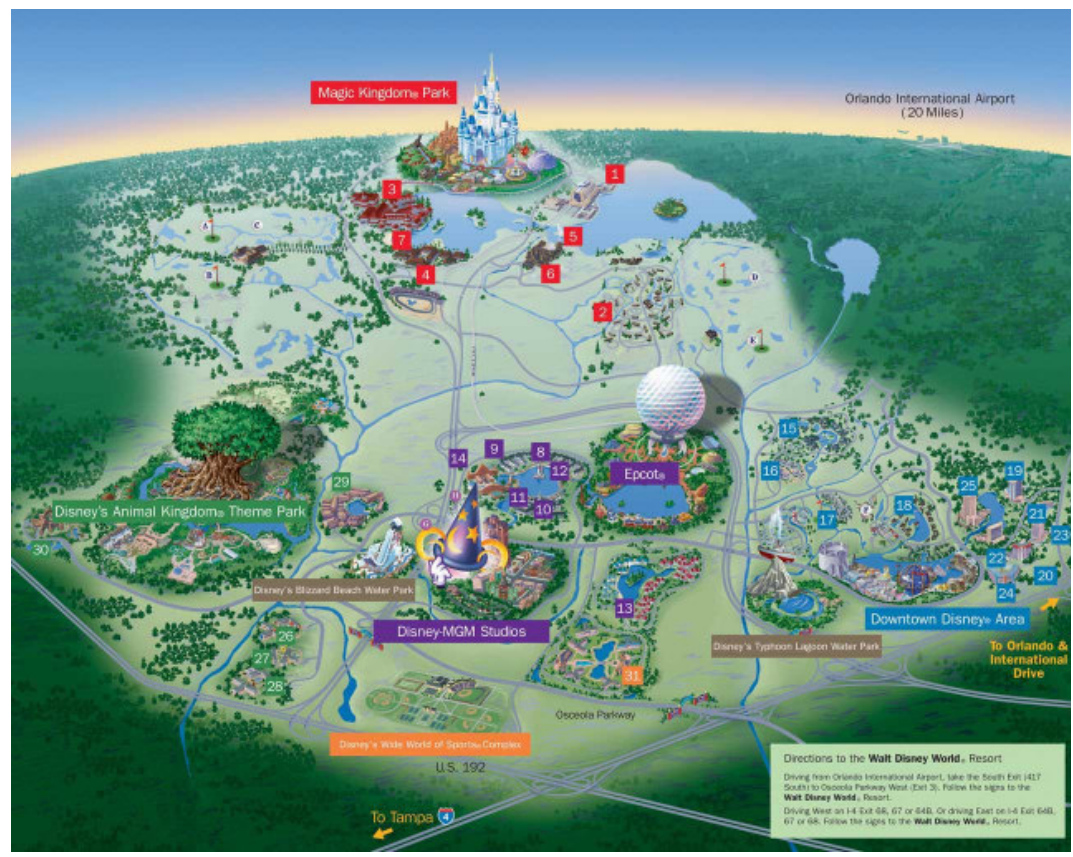

Fig 26. Mapa de Walt Disney World. 
Entretanto, o fluxo de turistas que buscam a região cresceu vertiginosamente já nos anos que seguiram a inauguração de Walt Disney World, em 1971. Os indicadores econômicos da cidade de Orlando apontam que, entre este ano e o seguinte, as vendas de automóveis e vendas, de um modo ge-

16. Idem p.131. ral, cresceram $40 \%$, e o números de embarques aéreos $119 \%{ }^{16}$

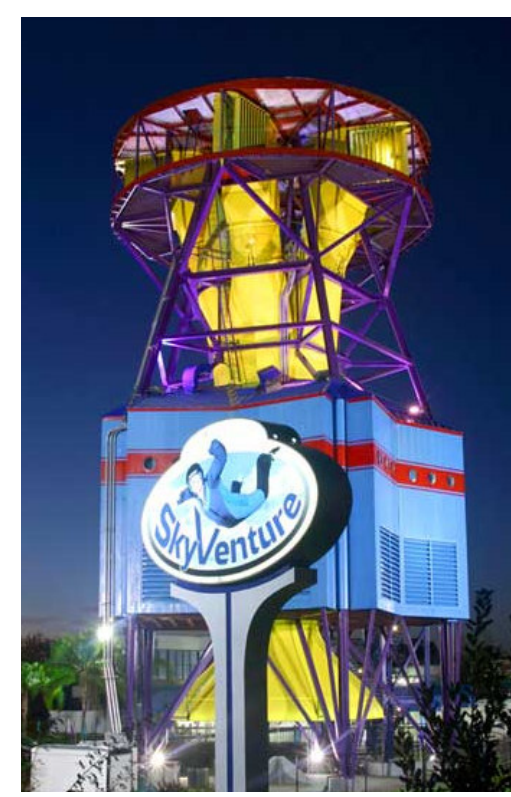

Fig 27. Sky Venture, estabelecimento de menor porte em Orlando.
Evidentemente este crescimento foi acompanhado por maior oferta hoteleira e de serviços que atendessem ao turista.

Assim, ainda que a área pertencente a Disney esteja geograficamente isolada, seu entorno foi tomado por atrações, incluindo, além de estabelecimentos menores, outros grandes complexos de parques, como a Universal e o Sea World. Mesmo que não vejamos o agrupamento formado pelos complexos de lazer, de escala urbana, e que a área central da cidade nada tenha de temática, a cidade é turisticamente divulgada como um grande conjunto de parques. Além disso, se estes complexos ficam isolados e cercados por grandes áreas de estacionamento, nas estradas percorridas pelo turista pode-se identificar uma seqüência contínua de atrações de pequeno porte ladeadas pelos outdoors que anunciam os parques e seus temas.

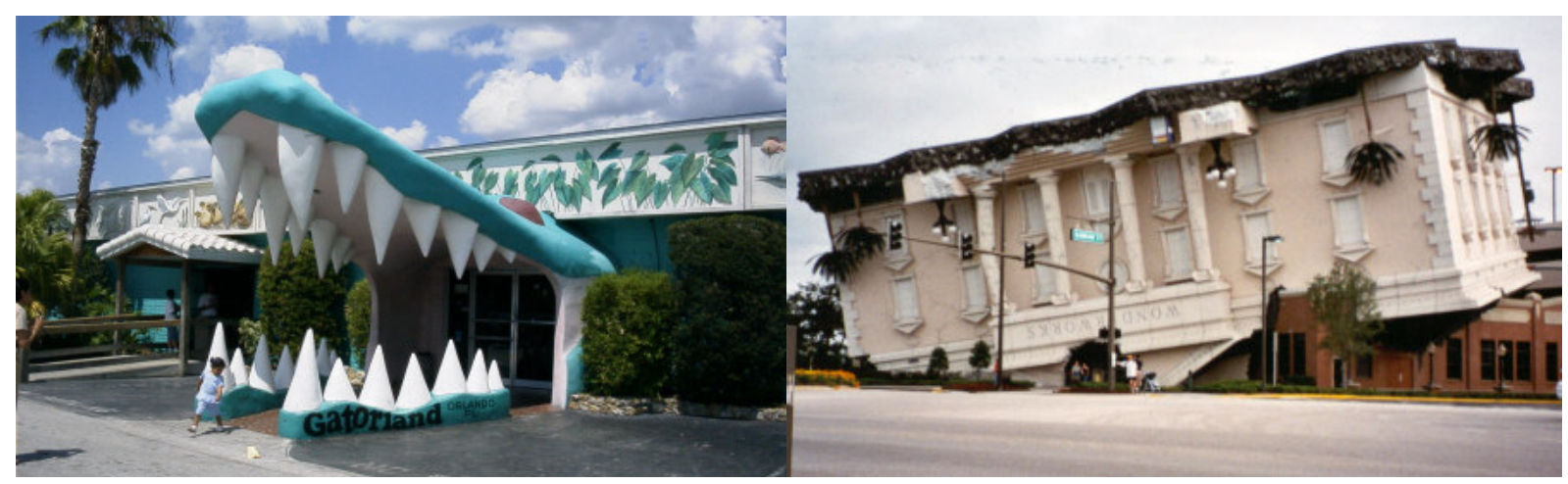

Figs 28 e 29. Gatorland e Wonder Works, estabelecimentos de menor porte em Orlando.

Assim como os arredores de Walt Disney World, em Orlando, a área central de Las Vegas converteu-se em uma colagem de estabelecimentos temáticos que, percebidos em conjunto, tornam a cidade um grande complexo temático. Em Las Vegas, pela continuidade das edificações, fica ainda mais evidente a noção de agrupamento, pois é possível visualizar simultaneamente vários cassinos, localizados lado a lado na Strip.

A cidade parece dever muito de sua configuração à es- 
17. VENTURI, SCOTT-BROWN e IZENOUR (2001). Ver Capítulo 1.3

trutura voltada para o fluxo rápido de veículos, com os cassinos localizados ao longo da Strip, como analisaram Venturi, Scott Brown e Izenour ${ }^{17}$. Os primeiros hotéis-cassino localizavam-se na Freemont Street, via de escala pedestre, mas logo foram construídos grandes complexos ao longo da Las Vegas Boulevard, especialmente no trecho conhecido como The Strip, via com escala para veículos. Esta configuração levou ao uso de grandes outdoors que se sobrepunham às edificações, determinando um reposicionamento do simbólico na arquitetura. Logo, para atrair público os empreendimentos passaram a reformular suas placas gigantescas, seja substituindo-as por maiores, seja incluindo novas mídias que chamassem maior atenção.

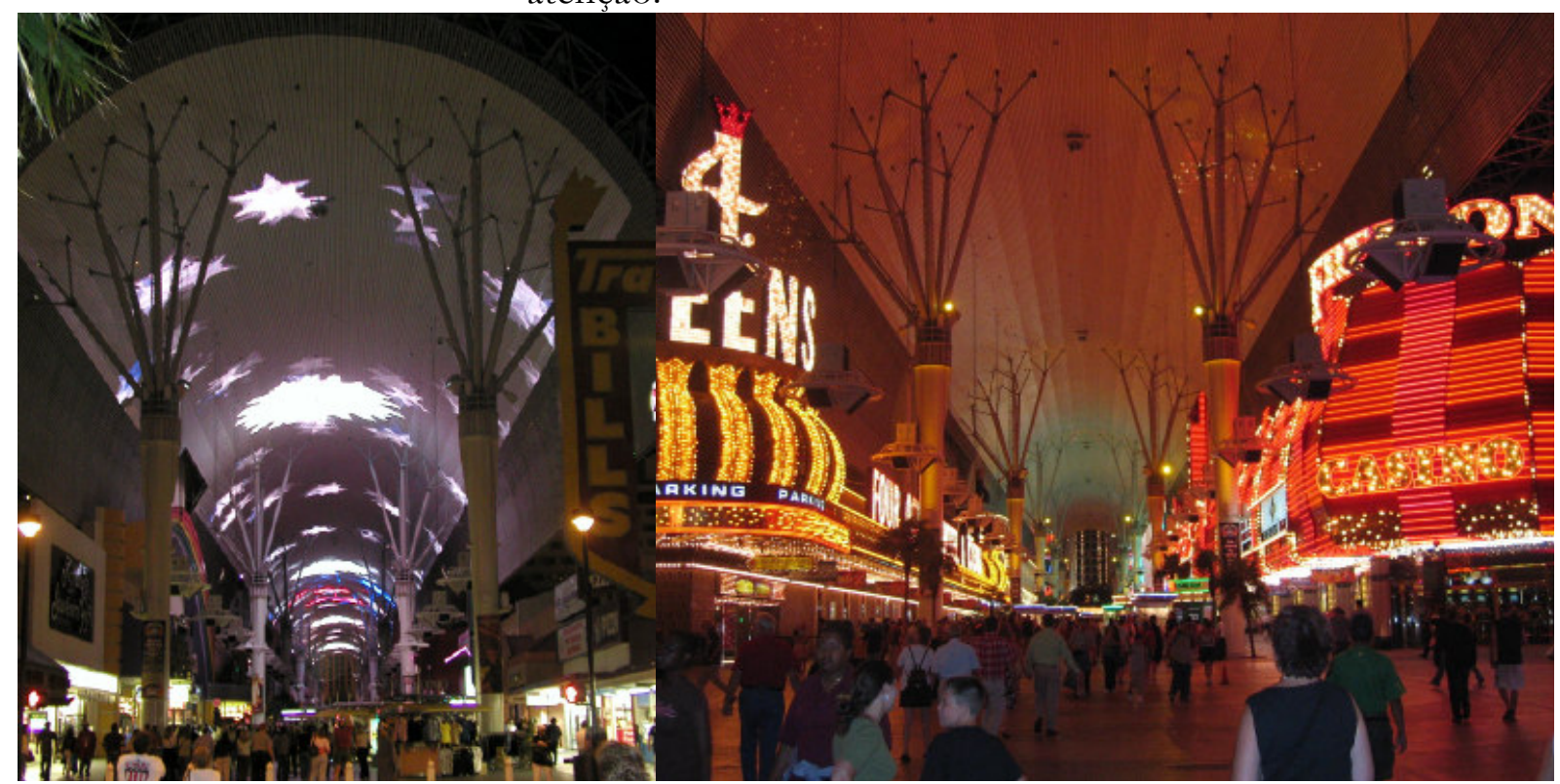

Figs 30 e 31. Freemont Street; Las Vegas. A antiga via central foi reconfigurada com show de som e luz, para atrair o

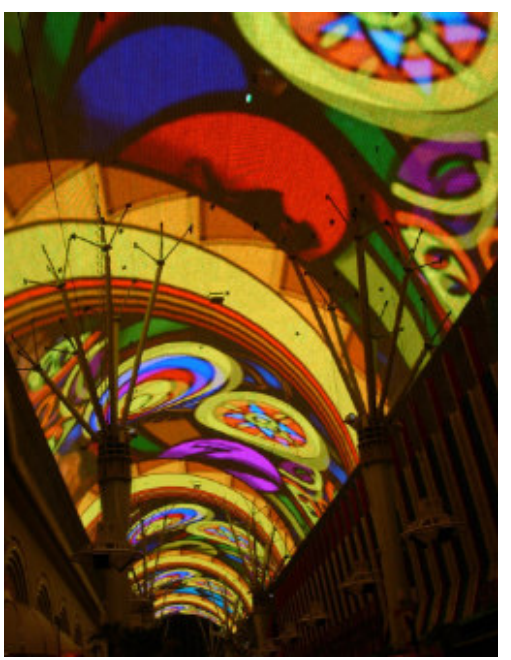

Fig 32. Show de som e luz na Freemont Street; Las Vegas detalhe. jogador que migrara para a Strip.

Além disso, os cassinos incorporaram a decoração figurativa com o propósito de atrair públicos mais diversos, famílias ao invés de jogadores. O tema funciona, ainda, como estratégia de distanciamento do apostador em relação ao espaço externo, incentivando o jogo por períodos mais longos. Hoje, o modelo temático é regra em Las Vegas, com a quase totalidade dos complexos da Strip adotando arquitetura narrativa que remete a tema pré-determinado.

Os temas histórico-culturais acrescentam ao empreendimento um referencial já consolidado. Um exemplo desta tentativa pode ser identificado no Hotel-Cassino Caesar's, cuja temática é a Roma antiga ou em seu equivalente mais recente, 


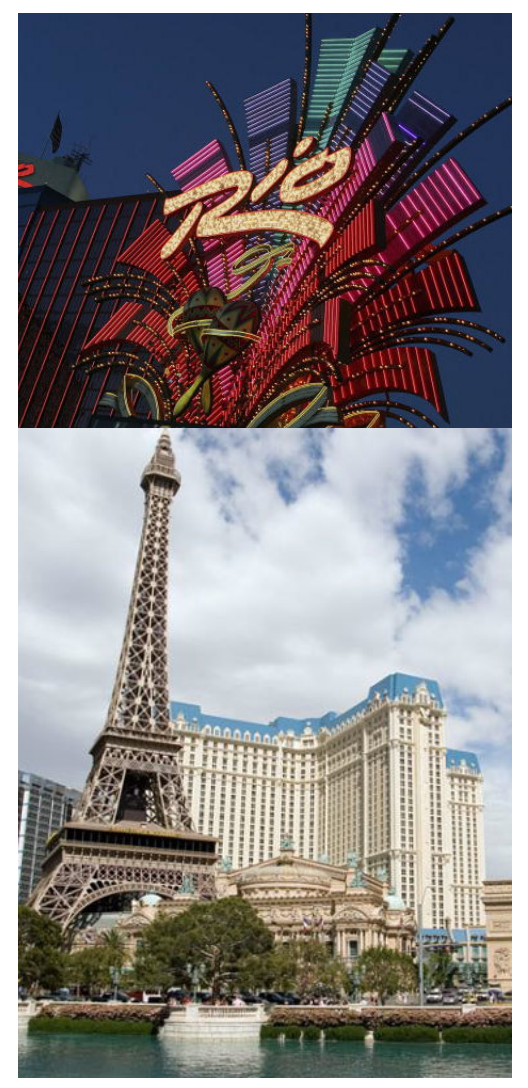

Figs 33 e 34. Cassinos Rio All-Suite e Paris las Vegas. o The Venetian, inspirado na cidade de Veneza, a ponto de contar com canais e Gôndolas disponíveis para os visitantes, inclusive com cantores, replicando a tradição da cidade original. Buscou-se nestes projetos representar suntuosidade, fazendo uso do tema e de formas clássicas que trazem consigo a idéia de luxo e poder. São de fato dois dos mais luxuosos empreendimentos da cidade. Da mesma forma há temas inspirados em famosas cidades turísticas, caso do Paris Las Vegas e do Rio All-Suite Hotel e Casino, como meio de dotar os complexos das características associadas às cidades inspiradoras. Entretanto, o universo temático de Las Vegas é dos mais amplos, incluindo, por exemplo, temas mais voltados para o universo infantil, como nos complexos Treasure Island (piratas), Excalibur (o período medieval) e Circus circus (o universo circense), além de outras referências, como o Egito antigo no complexo Luxor. Esta coletânea de temáticas distintas faz com que a Strip seja percebida como um grande parque temático a céu aberto.

Assim, mesmo que não haja intenção em tornar uma cidade temática, vimos que sua vocação turística pode vir associada à proliferação de estabelecimentos temáticos que, acumulados, fazem com que o local seja associado ao modelo temático. Ao contrário do exemplo anterior, não se trata de cidade planejada, tampouco de uma temática uniforme, e sim de um sistema configurado por inúmeros Espaços Temáticos sobrepostos.

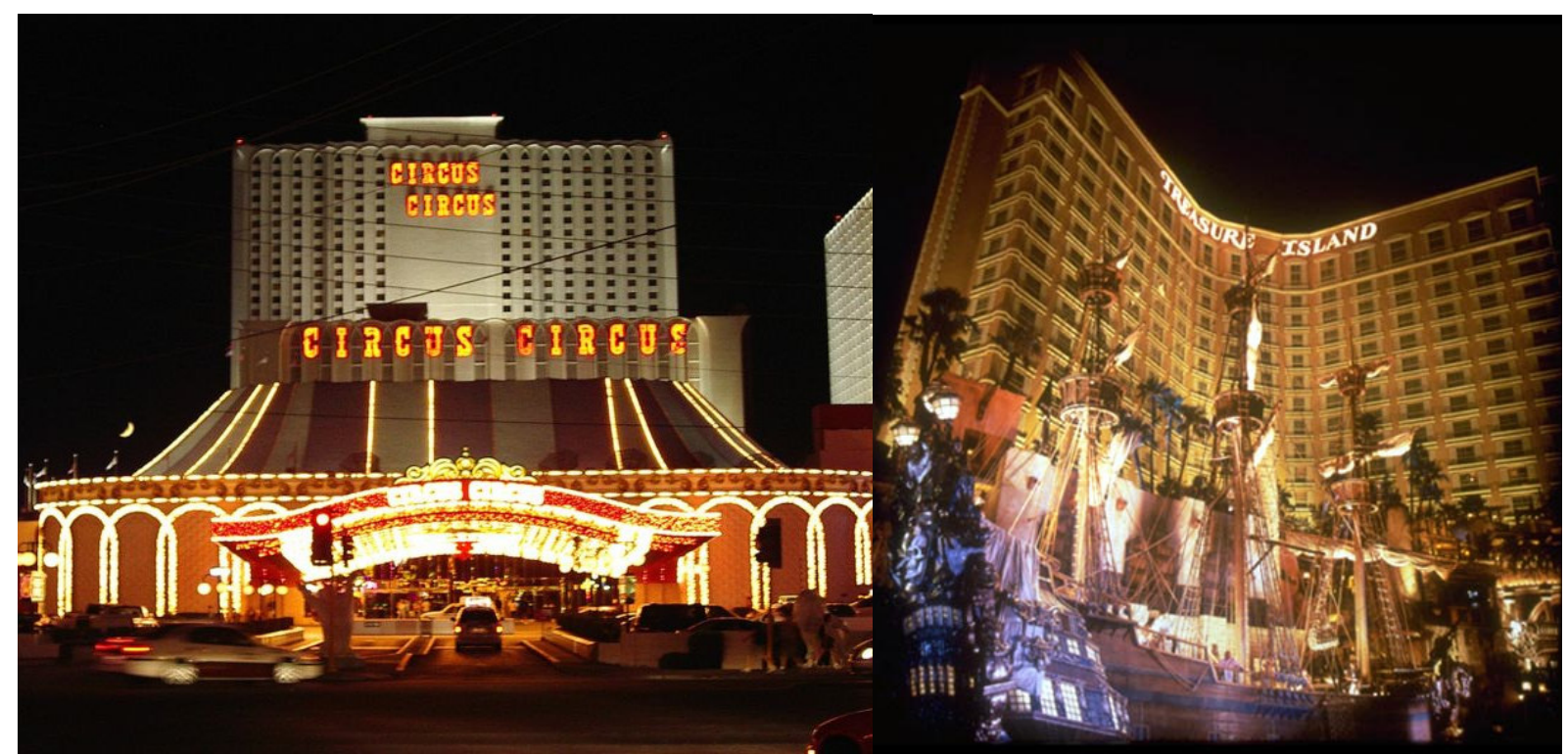

Figs 35 e 36. Cassinos Circus Circus e Treasure Island. 
3.3 Há uma grande quantidade de Espaços Temáticos, coHistória e Tema merciais, que obtêm visibilidade ao evocar um caráter histórico-cultural, seja pretendendo-se relevante culturalmente, seja optando pela exploração de uma temática histórica. Por outro lado, cresce a situação inversa. Há uma série de sítios históricos e museus que obtêm sustentabilidade financeira através da incorporação de características do temático. Assim, considerando que os recursos históricos estão sendo transformados em produtos turísticos, em mercadorias, talvez seja possível afirmar que, cada vez mais, estamos tratando de mercadorias embaladas sob a ótica do temático. No livro "A Alegoria do patrimônio", Françoise Choay afirma que

“(...) os monumentos e o patrimônio históricos adquirem dupla função - obras que propiciam saber e prazer, postas à disposição de todos; mas também produtos culturais, fabricados, empacotados e distribuídos para serem

18. CHOAY (2001) p.211. consumidos." 18

É legítimo, portanto, questionar até que ponto monumentos históricos já podem ser encarados enquanto espaços de entretenimento. Será que estes ícones adquirem valor perante a sociedade somente através do espetáculo? Onde se localizaria o limite nesta interseção entre valor histórico real e espetáculo produzido? Traçando um quadro comparativo, pode-se perceber que, atualmente, aproximam-se os espaços voltados, a princípio, para o turismo histórico e de entretenimento.

De um modo geral, observamos nos museus e centros culturais de hoje uma tendência em usar o temático como veículo. O propósito educativo - ainda que em certos casos não esteja desvinculado do aspecto comercial - pode ser atingido através do uso da Arquitetura Temática, quando são concebidos dioramas e espaços cenográficos para exposições, por exemplo. Neste caso, o objetivo do projeto pode ser reproduzir condições para contextualizar o visitante em relação à determinada época ou cultura.

Em situações como esta, o temático funciona associado à concepção do espaço de exposição como forma de facilitar a identificação do assunto de que trata a exibição. Embora seja evocado o propósito educativo, em alguns casos pode-se 
20. Um passeio pela história Espetáculo de som e luz no Museu de Petrópolis. In. Revista Veja Rio, parte integrante da Revista Veja. São Paulo: Editora Abril, Ano 35. No 47. fazer uso da arquitetura temática priorizando a apreensão rápida e superficial do tema. Assim, ainda que exista o objetivo de transmissão eficiente de informação, museus podem incluir temas no seu espaço para divulgar exposições e eventos para novos públicos alvos, atraídos pelo espetáculo. O lado questionável da prática seria a substituição ocasional da informação consistente pela alegoria pura, ou como vimos, a substituição 19. Ver Capítulo 1.4 do objeto original por réplicas “oficiais". ${ }^{19}$ Em março de 2008, por exemplo, a Exposição "Leonardo Da Vinci - A Exibição de um Gênio”, na Oca, trouxe a São Paulo cerca de 150 peças, todas réplicas de originais de Da Vinci que não saem dos museus em que estão.

Cada vez mais se estabelece um diálogo entre o Patrimônio Histórico e Cultural e o espetáculo, muitas vezes através da Arquitetura Temática. No Brasil, o projeto "Som e Luz", coordenado pela Fundação Roberto Marinho, apresenta um show de luzes e efeitos sonoros realizado nos jardins do Palácio Imperial, em Petrópolis. O público, recebido por funcionários caracterizados com costumes de época, assiste, na fachada do Palácio, a projeções inspiradas na história do local, inclusive simulando bailes e eventos do Império. ${ }^{20} \mathrm{O}$ espaço é, portanto, transformado em cenário de um espetáculo que tem o objetivo claro de envolver o freqüentador, fazê-lo sentir-se parte da história, exatamente como nos ambientes temáticos voltados para o comércio e lazer.

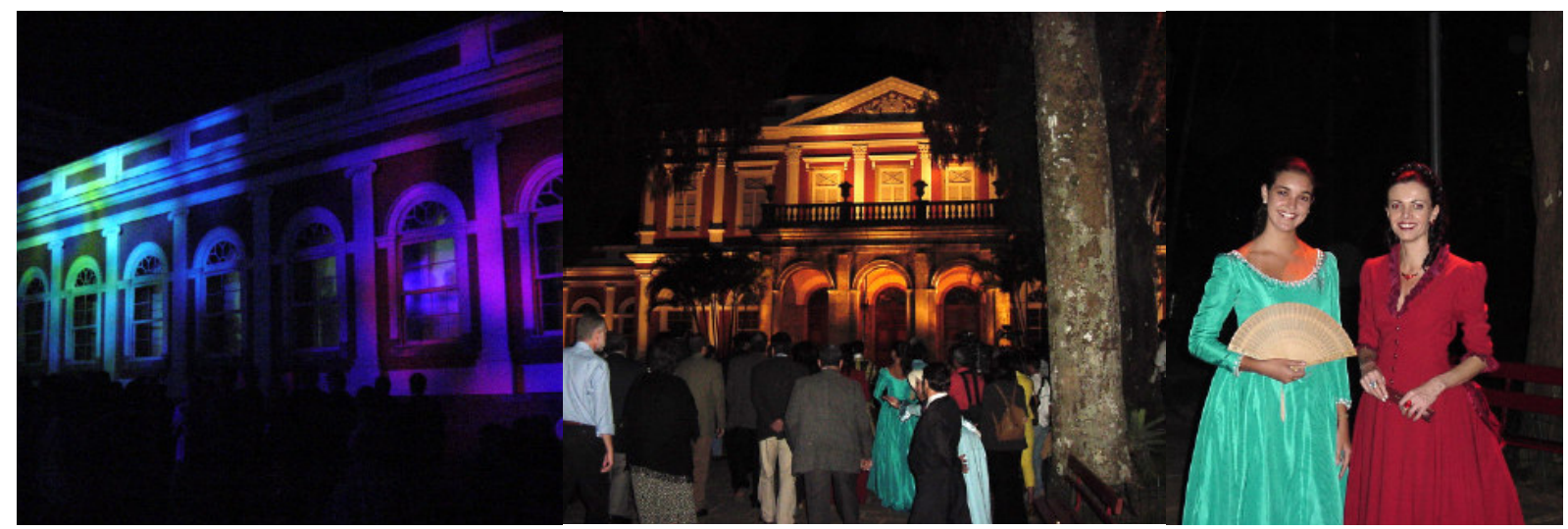

Figs 37, 38 e 39. Show de som e luz no Museu Imperial; Petrópolis.

Outros shows de som e luz têm feito sucesso em sítios históricos em todo o mundo. Além do espetáculo já citado em Chichen Itzá, shows semelhantes eram realizados até 2000 na 21. www.athensinfoguide.com Acrópolis Grega. ${ }^{21}$ Dentre os palcos históricos para espetácu- 
los de som e luz podemos citar ainda as pirâmides de Gizé e o templo de Karnak, no Egito, o Red Fort, na Índia, e as cidades medievais de Rhodes, na Grécia e Carcassonne, na França.

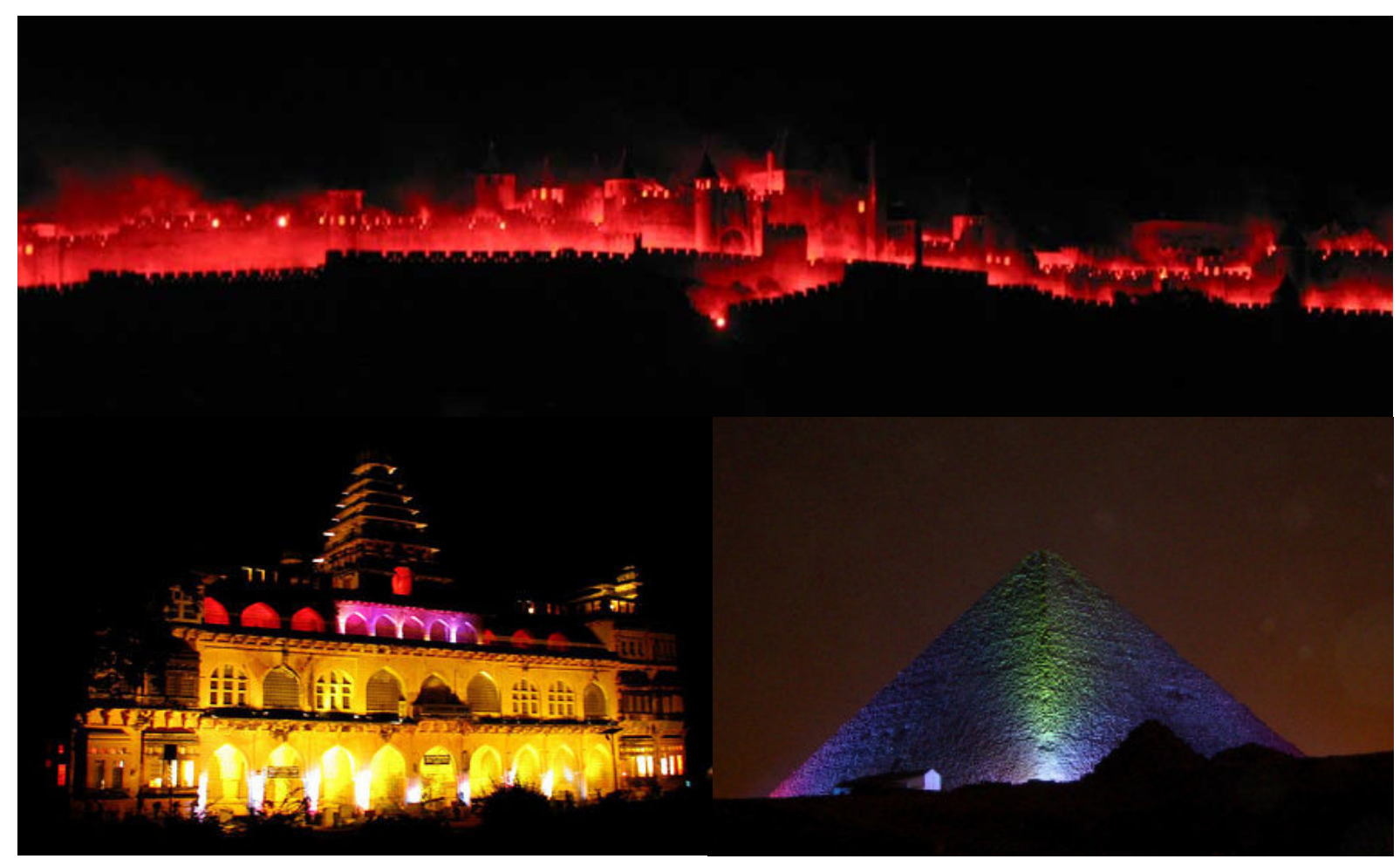

Figs 40, 41 e 42. Shows de som e luz em Carcassone; França, Red Fort; Índia, e na pirâmide de Khufu; Egito.

Vimos, portanto, como espaços de valor histórico-cultural se apropriam de elementos temáticos, comerciais. Por outro lado, Espaços Temáticos, claramente comerciais, numa situação inversa e, simultaneamente, análoga, se apropriam da história.

Dentre outros exemplos de museus associados a produtos ou empresas, podemos citar o museu da Coca-cola, em Atlanta. Este se pretende legítimo enquanto valor histórico, ao exibir a evolução da marca relacionada à evolução cultural norte-americana. O produto se distancia momentaneamente de sua característica mercadológica para mostrar-se enquanto elemento característico da cultura local, coisa que de fato é. Desta forma, a marca adquire novo valor ao ser apresentada, não como produto comercializável, mas como cultura.

Mesmo os Espaços Temáticos assumidamente comerciais, como bares ou centros de lazer, podem apresentar áreas dedicadas a culturas específicas, recontextualizando elementos delas extraídos. A paisagem se converte em uma coleção de símbolos que são descontextualizados e recontextualizados, 
conforme a facilidade de apreensão pelo freqüentador. Como vimos, nos casos em que o tema é um local ou uma cultura, não é apresentada uma reprodução de locais existentes na cultura inspiradora, e sim elementos pinçados que representam a visão que se tem desta cultura. Ainda assim, inúmeras vezes o estabelecimento se coloca como uma experiência cultural.

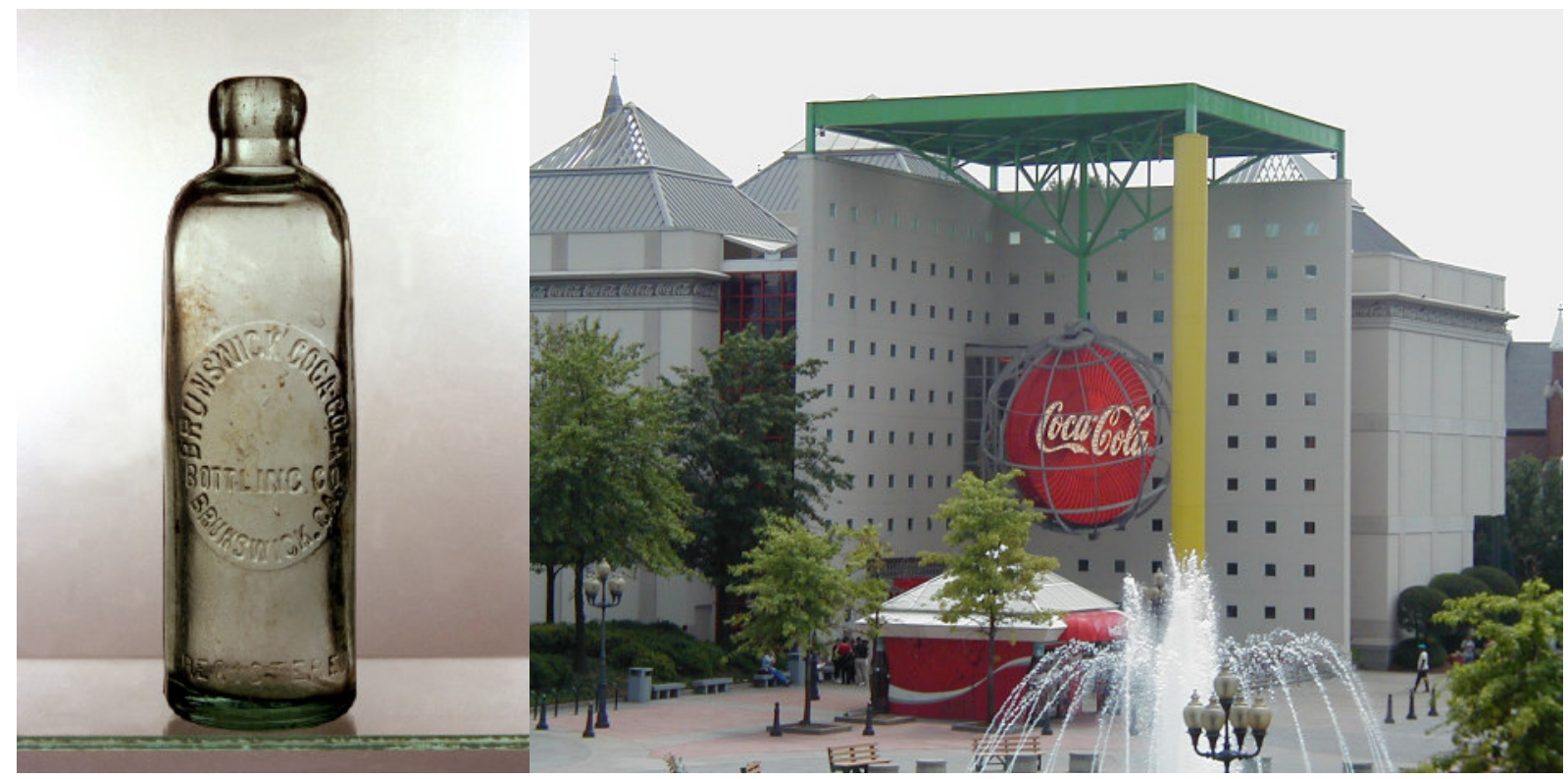

Figs 43 e 44. Uma das primeiras garrafas do refrigerante, em exibição no local e museu da Coca-cola; Atlanta.

A representação do passado, onipresente nos Espaços Temáticos, costuma refletir uma visão comprometida. Esta temática "histórica" trata da imagem que temos hoje acerca de um passado, uma visão idealizada. Este tipo de visão contemplativa da história é encontrada em Espaços Temáticos com bastante freqüência. Stephen Fjellman cita o exemplo da antiga atração Hall of Presidents, em EPCOT Center, cujo mote é a constituição norte-americana. Curiosamente o show que se propõe a recriar o momento em que foi escrita a constituição, inclui vozes femininas, mesmo que na época as mulheres não possuíssem qualquer direito político. A história é contada não como aconteceu, mas como deveria ter acontecido, ou como

22. FJELLMAN (1992) p.67. “(...) In order to suggest the appropriate idea of history,

Disney pedagogy must suppress, rearrange, and invent history in the interest of safe dramatic presentation." disse Fjellman: “(...) Para transmitir a impressão apropriada da história a pedagogia Disney precisa suprimir, reordenar e inventar a história segundo o intersse da apresentação dramática prudente." 22

A Main Street nos parques da Disney, por exemplo, foi concebida como uma representação da rua principal da cidade natal de Walt Disney, Marceline, Missouri. No entanto, sabe- 
se que se trata, na realidade, da representação da visão que ele tinha sobre sua cidade, uma vez que o local é mostrado de maneira totalmente idealizada. Neste sentido, podemos identificar a criação de uma tradição a partir da reconstrução da main street tradicional sob os olhos de Walt. Após a inauguração do primeiro parque, inúmeras pequenas cidades espalhadas pelos Estados Unidos passaram a restaurar suas main streets, fazendo com que estas se assemelhassem à construída por Walt Disney. Surge, com isso, uma "Nova Main Street Tradicional". Passou-se a acreditar que era aquela a imagem do passado destas cidades. Assim, o modelo temático-histórico passa a ocupar também o espaço urbano. Um dos exemplos mais emblemáticos deste tipo de restauração é, inclusive, anterior à Main Street de Walt Disney, a já citada restauração de

23. Ver Capítulo 1.4 Colonial Williamsburg. ${ }^{23}$

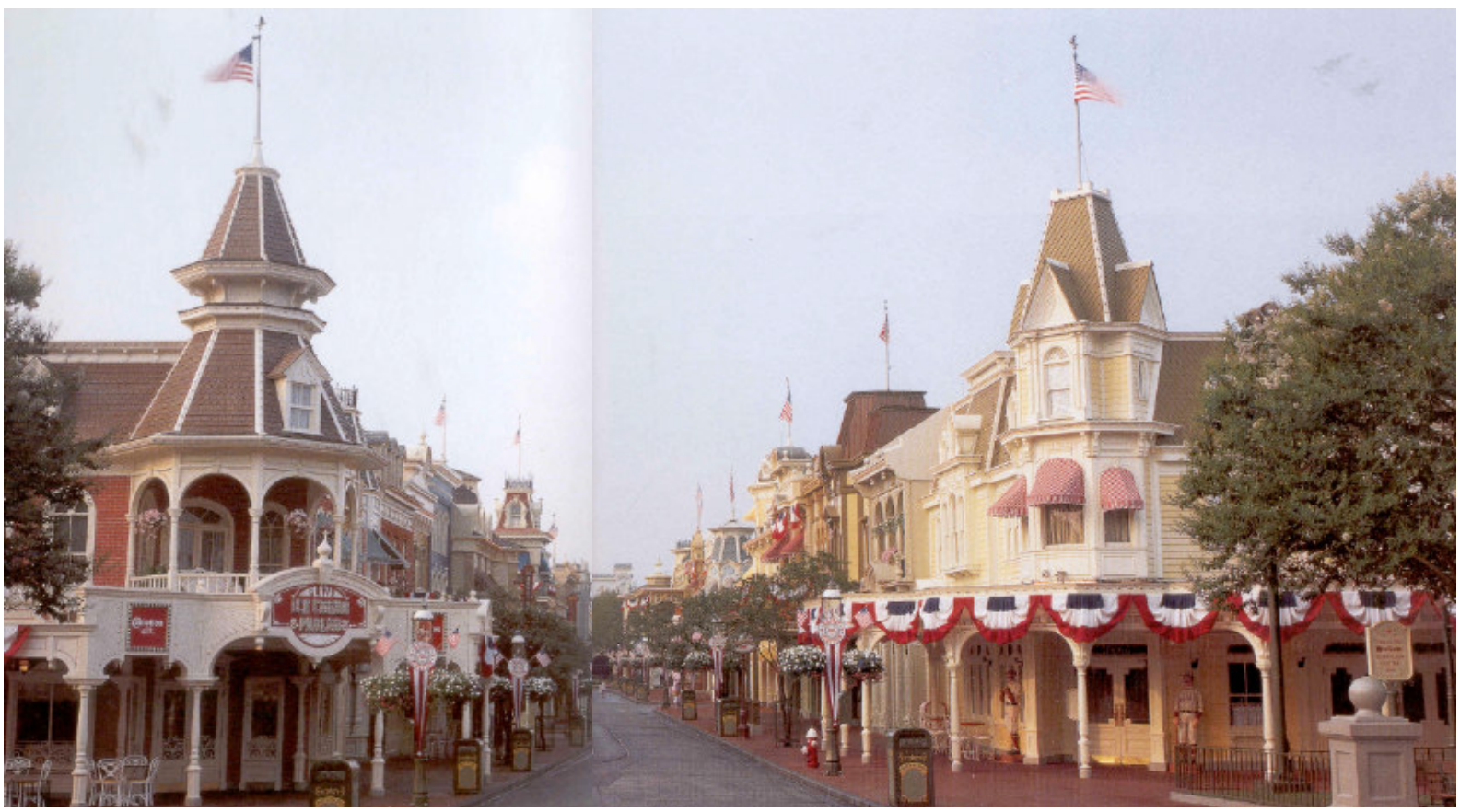

Figs 45 e 46. Main Street no Magic Kingdom, em Walt Disney World.

Além disso, sítios arqueológicos e cidades históricas também têm se assemelhado a parques temáticos, pois, cada vez mais, apresentam espetáculos que priorizam o entretenimento. Com isso, cresce a interação entre o temático e a história, configurando-se um sistema em que ambos modificam-se mutuamente. A história é evocada no temático e vice-versa, mas, além disso, o temático adquire o poder de alterar a forma como a história é contada. Os Espaços Temáticos podem “construir tradições", ou seja, divulgar uma visão particular 


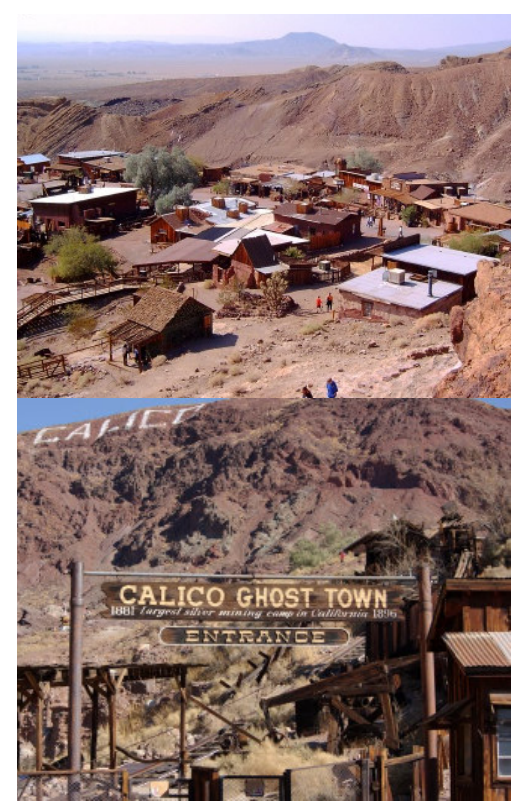

Figs 47 e 48. Calico Ghost Town, antigo pólo mineirador convertido em parque temático. da história e de culturas evocadas como referencial temático.

A conversão da história em foco de turismo cultural de massa parece aplicável a qualquer local. Mesmo cidades que, a princípio, não teriam relevância histórica a nível mundial ou nacional fazem de sua própria trajetória um tema a ser explorado em sua divulgação. Surgem, principalmente nos EUA e Canadá, exemplos como a cidade de Santa Claus, a cidade fantasma do Velho Oeste, entre outras. Todas são remodeladas para evidenciar esta faceta da história camuflando outras, e, invariavelmente, exploram o tema em souvenirs e atrações pagas.

Portanto, seja como única alternativa para a sustentabilidade financeira, seja como instrumento publicitário, ou como veículo educacional, o espetáculo é pouco a pouco agregado a espaços de importância histórico-cultural e, mais que isso, ao espaço da cidade. Se em Espaços Temáticos comerciais temos como temas centrais personalidades famosas, cartoons, etc, nos sítios históricos a própria história local é explorada como tema. Com a visibilidade adquirida, o tema se torna ou se fortalece enquanto ícone, símbolo que representa a cidade ou região e atrai o turista. Porém, para que isso aconteça são necessários, em muitos casos, não só a renda e publicidade oriundas do espetáculo, mas acordos de patrocínio firmados com grandes empresas. Assim, ao mesmo tempo em que é explorado o tema histórico-cultural, aparece como temática a identidade corporativa, os signos que identificam a empresa patrocinadora.

Dentro do contexto exposto, questionamos se a história é tema, ou se o temático é histórico, ou seja, se a história é transformada em tema, seja em Espaços Temáticos, seja em sítios históricos, ou se realmente estes espaços concebidos com inspiração em uma temática pré-estabelecida podem sim ter valor cultural. Se os museus contemporâneos apresentam características emprestadas dos Espaços Temáticos, a associação entre o temático e a cultura já faz com que se pense que, através destes Espaços, poderá, futuramente, ser contada a história de nosso tempo. Stephen Fjellman, professor da Uni24. FJELLMAN (1992) p.403. versidade da Florida, ${ }^{24}$ defende a tendência de que o futuro dos Parques Temáticos, ou pelo menos de Walt Disney World, é 
25. Ver Capítulo 1.5 mação com o Campo de Produção Erudita. ${ }^{25}$

Assim, se hoje os museus e sítios de interesse histórico acompanham a tendência aqui enunciada e se tornam, sob certo aspecto, temáticos, os Espaços Temáticos comerciais se apresentam como signos culturais e gradativamente adquirem valor enquanto capital cultural. O turista, ao visitar tanto os sítios históricos e museus quanto os Espaços Temáticos, busca a experiência do entretenimento agregada ao status que advém do aspecto histórico-cultural.

3.4 Os desejos e necessidades da população local constiTemáticas e assumidas tuem alguns dos principais fatores a serem considerados ao longo da concepção e implantação de todo projeto urbano. Uma das formas mais efetivas de envolver a população neste processo tem sido o resgate de tradições locais. Este resgate costuma ser visto como elemento essencial para o sucesso de um projeto urbanístico, já que a população, a princípio, teria maior interesse na manutenção de sua cidade quanto maior fosse sua identificação com a mesma.

A partir do início dos anos 90, começa a aparecer nos Estados Unidos um novo movimento denominado New Urbanism, que igualmente se propõe a projetar considerando tradições locais. Relacionam-se tipos tradicionais que passam a 
26. KATZ (1994) p.xii.

compor o repertório do projeto, fazendo com que a população se identifique com a cidade. Há, ainda, uma previsão de crescimento da cidade para que as condições, com o passar dos anos, melhorem, evitando a degradação. Em primeiro lugar, devemos entender como e porque este modelo - New Urbanism - foi difundido. Para tanto, precisamos entender a formação das cidades norte-americanas nos últimos 50 anos.

de crescimento era o dos subúrbios conectados aos grandes centros por vias expressas, onde eram oferecidas residências com crédito hipotecário do governo federal. Essa conjugação de acesso fácil ao local de trabalho e habitação a custos mais baixos atraiu grande contingente populacional para os novos subúrbios; no entanto, fez com que crescessem muito e passassem a abrigar um grande número de empregos. Conseqüentemente, surgiu uma rede de subúrbios secundários, criando um novo modelo de deslocamento diário entre subúrbios de porte, hoje superior aos deslocamentos em direção aos grandes centros. Evidentemente, a tranqüilidade e segurança dos subúrbios foi substituída por stress, devido a grandes congestionamentos, crime, poluição, altos custos de manutenção e isolamento. Por outro lado, o próprio núcleo familiar sofreu alterações. As famílias já não são tão grandes e deixou de fazer sentido a figura do pai provedor e da mãe dona-de-casa, personagens emblemáticos na vida dos subúrbios norte-americanos. O New Urbanism surge propondo repensar estas questões.

Desenvolvido a partir da década de 80, por um grupo de profissionais reunidos em congressos periódicos (Congress of New Urbanism), o novo modelo que propunha alternativas à vida suburbana ganhou força ao longo da década de 90. Entre suas características fundamentais estão a implementação de um zoneamento misto, mais flexível que o dos subúrbios, e maior densidade ocupacional. Tais mudanças fariam com que muitos trajetos pudessem ser percorridos a pé, dispensando o uso constante de veículos. Por outro lado, as medidas reduziriam o isolamento, incentivando uma relação mais estreita entre vizinhos que se encontrariam com maior freqüência e, ainda, permitiriam frear a ocupação de áreas preserváveis, 
27. LARA, Fernando. Admirável Urbanismo Novo. In. Arquitextos - periódico mensal de textos de arquitetura (online) http://www. vitruvius.com.br

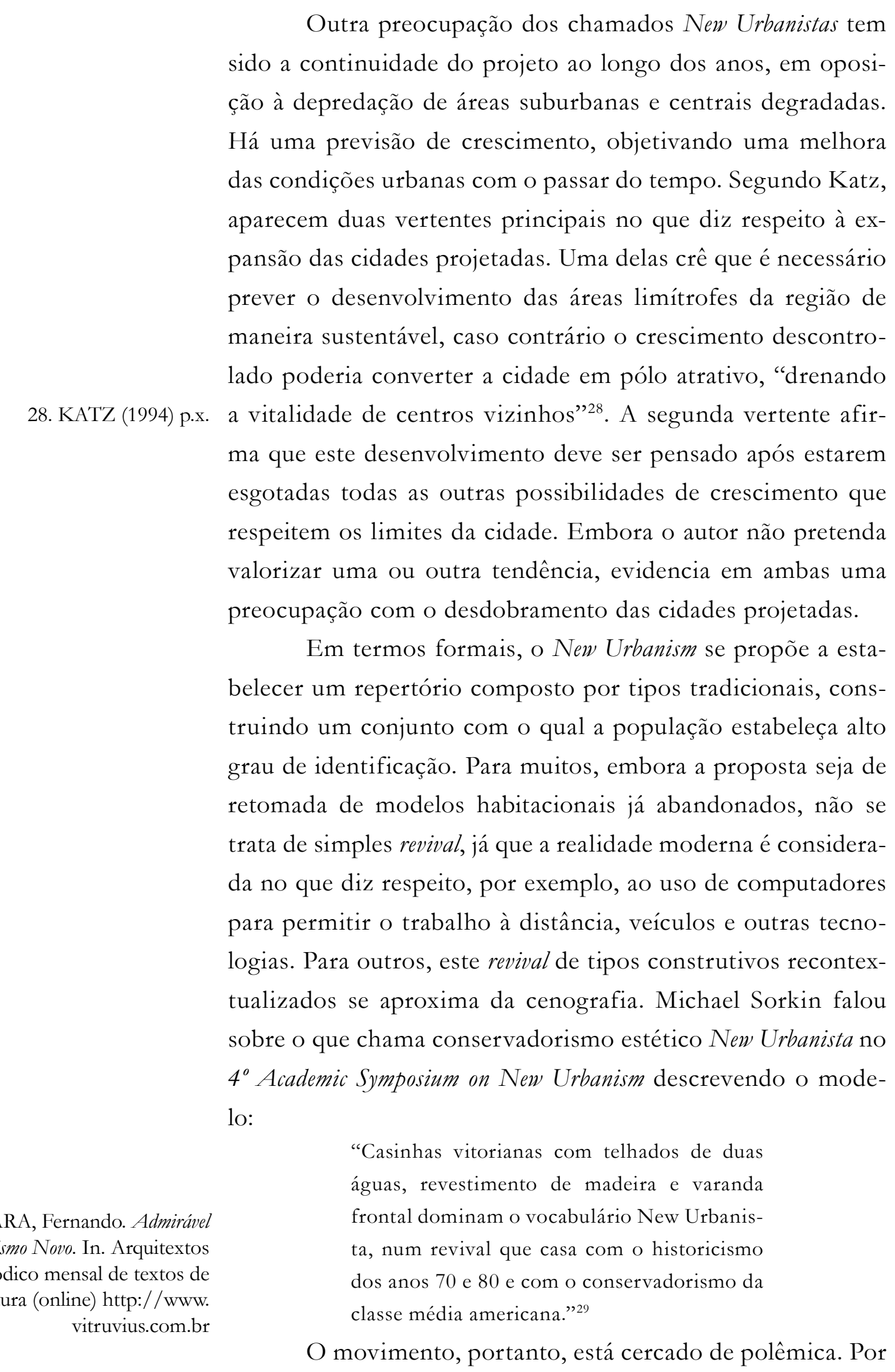

reduzindo a degradação ambiental. ${ }^{27}$ De certa forma, o New Urbanism propõe um retorno à comunidade compacta característica da ocupação norte-americana antes da implementação dos subúrbios.

Outra preocupação dos chamados New Urbanistas tem 
30. MARCUSE, Peter. The New Urbanism: The dangers so far. DISP 140, 2000. LARA, Fernando. Admirável Urbanismo Novo. In. Arquitextos - periódico mensal de textos de arquitetura (online) http://www.vitruvius.com.br um lado, atende às expectativas dos que se preocupam com a questão ecológica, ao favorecer a preservação ambiental e sustentabilidade dos projetos. Atende, ainda, aos interesses do mercado imobiliário, ao maximizar as taxas de ocupação. De um modo geral, os empreendimentos foram bem sucedidos, indicando também uma aceitação entre as populações atendidas, que buscam maior qualidade de vida e segurança.

No entanto, uma série de críticas sempre esteve associada aos projetos de inspiração New Urbanista. Afinal, por mais que ofereça uma opção viável para a ocupação de novas áreas, o modelo não atinge as áreas centrais. As propostas apresentadas se encaixam principalmente em novos empreendimentos, deixando sem solução os problemas dos grandes centros urbanos, e mesmo dos subúrbios já consolidados.

Para muitos autores, como Peter Marcuse ${ }^{30}$, as propostas atendem à classe média norte-americana e não seriam aplicáveis em casos de populações de renda mais baixa ou minorias raciais que, especialmente nos Estados Unidos, estão restritas a guetos urbanos. As cidades New Urbanistas seriam, na verdade condomínios fechados de grande porte que, embora favoreçam o contato entre vizinhos, acentuam o isolamento e as diferenças em relação ao restante da população.

Um dos fatores responsáveis por este possível isolamento é, também, fator para o sucesso de empreendimentos New Urbanistas com a população - a segurança. Seaside, na costa da Flórida, primeira aplicação prática das idéias New Urbanistas e reconhecida em 1990 pela revista Time como a melhor da década em termos de design, exemplifica esta idéia.

Em 1980, quando projetaram Seaside, os arquitetos Andres Duany e Elizabeth Plater-Zyberk tinham como objetivo fundamental criar um forte senso de comunidade. Para eles, a alienação característica das cidades contemporâneas é resultante do predomínio do espaço privado sobre o espaço público. Por isso, em Seaside, a opção foi pelo inverso. Primeiro foram desenhados os espaços públicos - ruas calçadas, praças e a área da praia, por exemplo. Só então foram projetados os edifícios, seguindo um código de possíveis tipologias, acessível aos moradores que realizavam seu próprio projeto dentro das várias possibilidades. A cidade foi projetada para 
uma população de dois mil habitantes, aproximadamente o tamanho de uma típica comunidade norte-americana do início do século XX. O projeto compacto favorece a interação entre os moradores e permite que os deslocamentos diários sejam feitos a pé, reduzindo a dependência dos automóveis.

O projeto previa que a cidade tivesse preços acessíveis, mas a oferta de maior qualidade de vida e segurança fez com que as propriedades se valorizassem. Ainda que os preços tenham caído em regiões próximas, em Seaside os valores au31. KATZ (1994) pp.3-17 mentaram, atraindo, inclusive, investidores. ${ }^{31}$

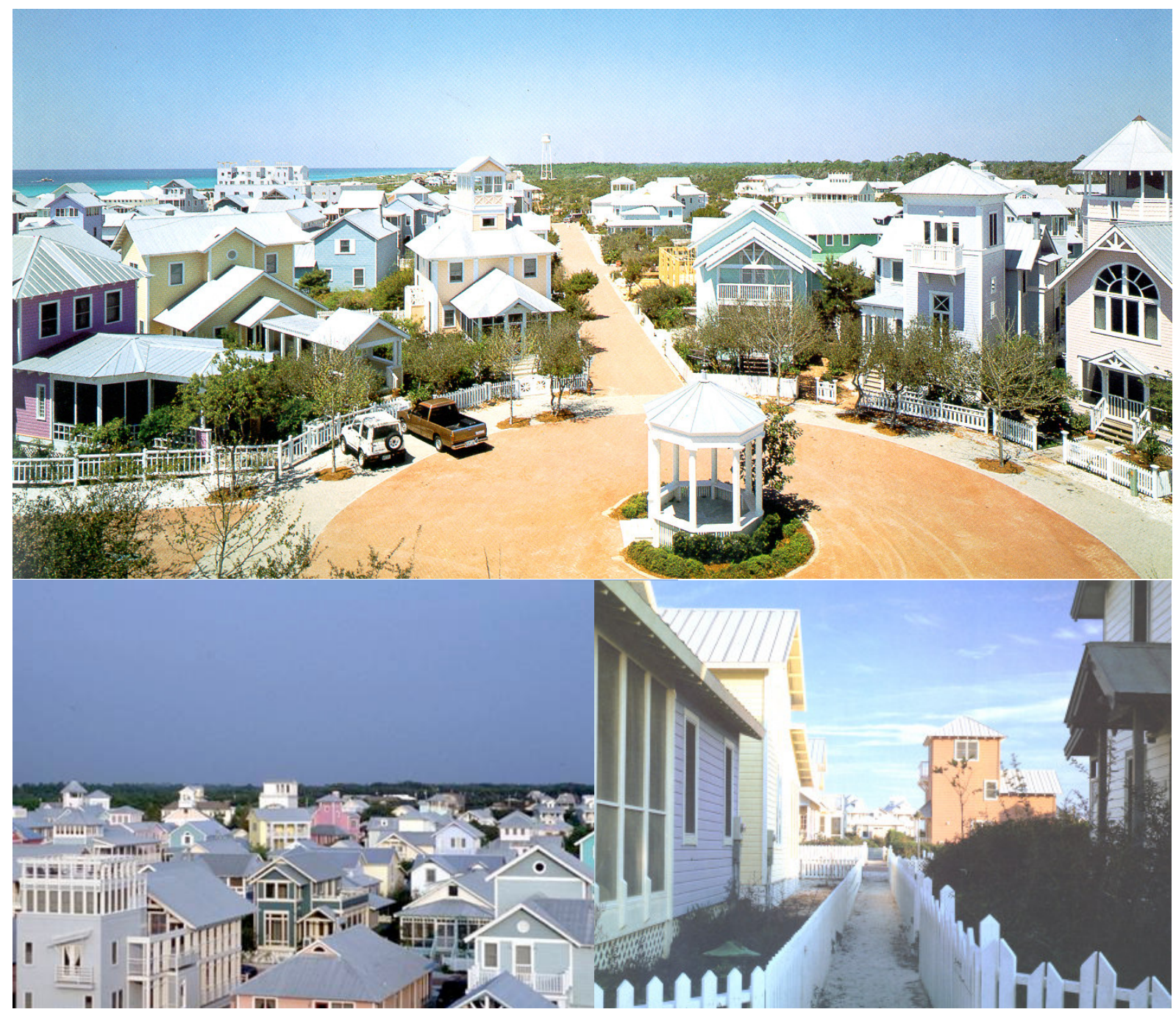

Figs 49, 50 e 51. Seaside - vistas gerais e via interna para pedestres.

32. O Show de Truman - The Truman Show . Paramount Pictures, 1998. Direção Peter Weir (102 min)

DVD.

33. ORWELL (2003)
Não por acaso, o filme "O Show de Truman"32 tem como cenário a cidade de Seaside. Em uma referência ao Big Brother de George Orwell ${ }^{33}$, o filme retrata a vida de um cidadão comum que, sem saber, é, desde seu nascimento, o protagonista de um reality show sobre sua própria vida. No filme, todas as outras "personagens" são atores contratados e a ci- 


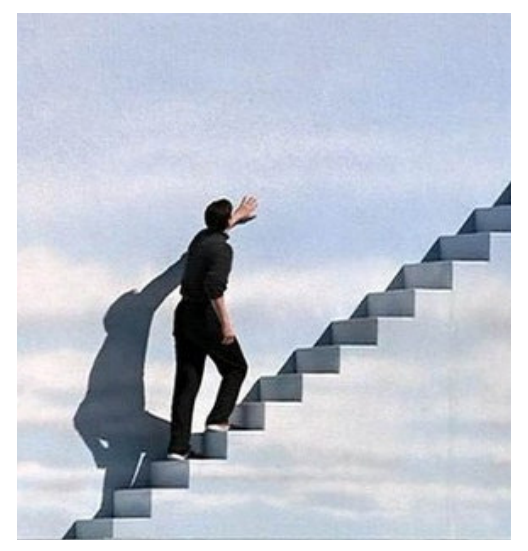

Fig 52. Truman descobre que vive em um domo isolado.

34. JACOBS (1973) pp.38-39 dade é, na verdade, um grande set de filmagem. Truman, o protagonista, vive então em um ambiente totalmente controlado, porém totalmente seguro. Nas cidades New Urbanistas o morador realmente tem pouca autonomia no que diz respeito aos aspectos políticos, mas pode ter grande importância no processo de projeto de sua residência. Normalmente, há um código rígido que define os padrões construtivos e determina que o morador não pode fazer qualquer alteração na aparência externa de sua residência, nem mesmo uma pintura com cores diferentes, porém o futuro proprietário pode, em várias experiências New Urbanistas, participar da escolha das tipologias usadas em sua residência.

Jane Jacobs ${ }^{34}$, ainda em 1961, havia dito que ruas muito freqüentadas são mais seguras. Segundo ela, uma das principais funções das ruas e calçadas seria garantir segurança. Nas grandes cidades, as ruas estão repletas de pessoas estranhas, pois, devido ao tamanho da população, mesmo vizinhos próximos costumam ser desconhecidos. Para que alguém se sinta seguro é fundamental que não se sinta ameaçado por estes estranhos. Jacobs identifica, então, três características essenciais para ruas seguras. Em primeiro lugar, deve haver uma diferenciação clara entre os espaços públicos e privados. Deve haver olhos que observem a rua, os moradores devem poder ver as calçadas e, para isso, os edifícios devem ter as janelas voltadas para a rua. Finalmente, as ruas devem estar sempre ocupadas, instigando os moradores a observarem através das janelas.

Há, em "O Show de Truman”, uma certa glamourização dos conceitos defendidos por Jane Jacobs sobre os "olhos que vêem" mas o fato é que, para garantir a tranqüilidade de estar sendo observado - por uma câmera de segurança, por exemplo - uma parcela da população está disposta a abrir mão de parte de sua autonomia. Segundo Fernando Lara, para este público

“Já não basta o isolamento conservador do subúrbio, é preciso que alguém lhes proteja das tentações e disfunções ameaçadoramente cotidianas como as muralhas e a ponte levadiça protegiam os camponeses que viviam ao redor do castelo." 35
35. LARA, Fernando. Vizinhos do Pateta. In. Arquitextos - periódico mensal de textos de arquitetura (online) Disponível: http://www. vitruvius.com.br

(1)


Esta opção pela segurança em detrimento à liberdade se evidencia em um dos casos mais comentados e polêmicos dentre os empreendimentos New Urbanistas: Celebration, mais conhecida entre os leigos como "a cidade da Disney". Por estar localizada dentro dos domínios da Disney World, Celebration tem características que a distinguem de outros empreendimentos.

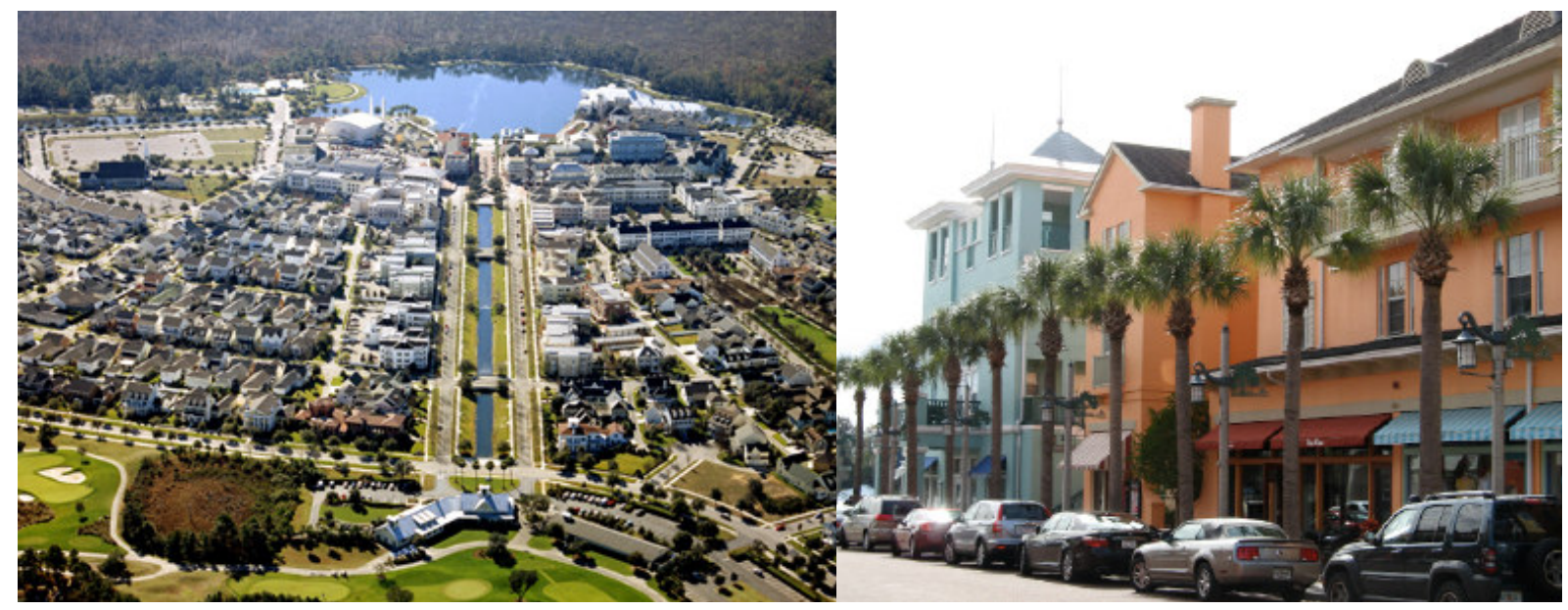

Figs 53 e 54. Celebration - vista aérea e rua.

Enquanto efetivava o projeto para o complexo, a Disney primeiro iniciou a compra da área, a partir de 1964, para depois iniciar os acordos com o Estado da Flórida. O principal trunfo da empresa era, sem dúvida, a atração de empregos, renda e turistas que o complexo traria para a região, além da possibilidade de trocar a Flórida central por outra localidade caso o acordo não fosse selado. Em 1967, a proposta da Disney foi aceita e assinada pela Câmara. A Disney se responsabilizaria por toda a infra-estrutura em seus domínios, incluindo a construção de rodovias, implementação de sistema de transporte público, estacionamento, proteção policial e anti-incêndio, além de assumir uma rígida política de preservação ambiental. Em contrapartida, o Estado tornou a área pertencente à Disney um distrito independente, denominado Reedy Creek Improvement Distrct, com autonomia política e administrativa, inclusive no que se refere ao pagamento de taxas e códigos de construção e zoneamento urbano. ${ }^{36}$

O projeto inicial para o complexo de parques incluía o uso habitacional em uma área denominada EPCOT - Experimental Prototype Community of Tomorrow - uma espécie de cidade do futuro em que seriam permanentemente testadas tecnolo- 
37. DUNLOP (1996) p.55 "It will be a planned, controlled community; a showcase for American industry and research, schools, cultural and educational opportunities. In Epcot there will be no slum areas because we won't let them develop. There will be no landowners and therefore no voting control. People will rent houses instead of buying them, and at modest rentals. There will be no retirees, because everyone will be employed according to their ability. One of our requirements is that the people who live in Epcot must help keep it alive." gias novas, incluindo um domo que cobriria toda a área para garantir controle até mesmo sobre o clima. A cidade teria um desenho radial, com o comércio na área central, circundado progressivamente por edifícios, cinturão verde e residências unifamiliares em baixa densidade. O projeto foi assim descrito por seu idealizador, Walt Disney:

"Será uma comunidade controlada e planejada; uma vitrine para a indústria americana, pesquisa, escolas e oportunidades culturais e educacionais. Em Epcot não haverá favelas porque não permitiremos que se desenvolvam. Não haverá proprietários de terra e, portanto, não haverá controle sobre o voto. As pessoas alugarão casas, ao invés de comprá-las e por um valor modesto. Não haverá aposentados, porque cada um trabalhará de acordo com suas habilidades. Um requisito para morar em Epcot será ajudar a mantê-lo vivo." ${ }^{37}$

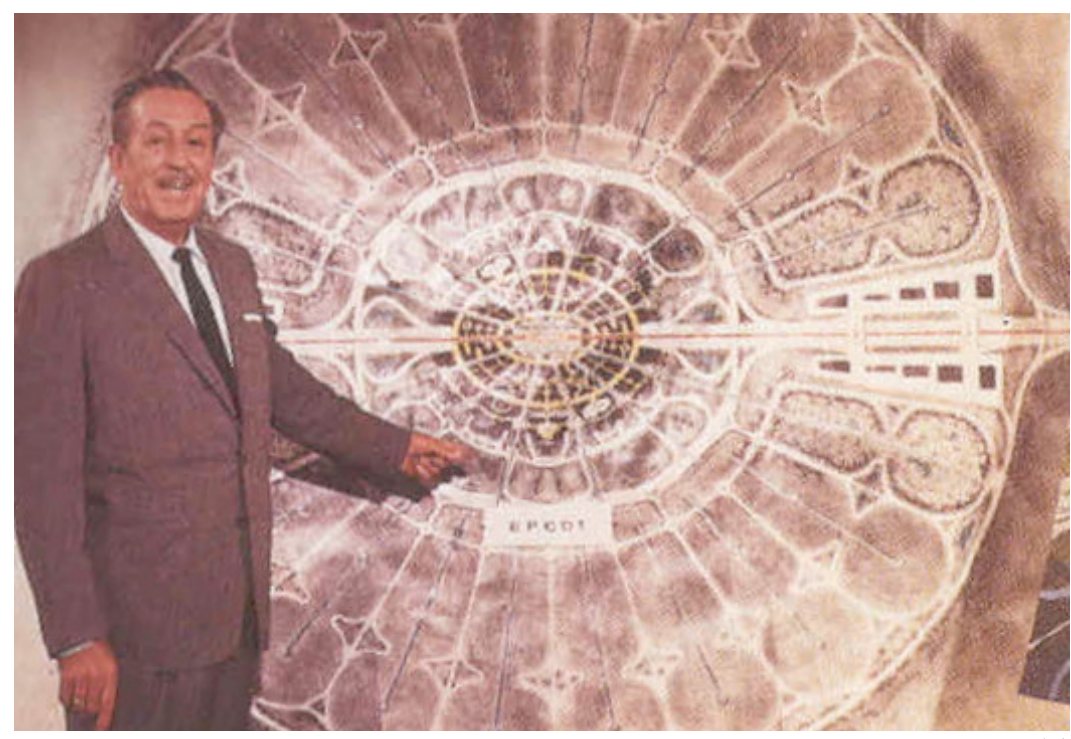

Fig 55. Walt Disney e o projeto inicial para EPCOT.

Porém, com a morte de Walt, a idéia foi abandonada e, ao ser inaugurado, em 1982, o EPCOT havia sido convertido em um parque temático, um protótipo de exposição universal com pavilhões nacionais e exposições tecnológicas. Embora novas tecnologias fossem o foco do parque, já não se tratava de uma cidade.

Como o Estado da Flórida exigia um número mínimo de habitantes no distrito, sempre houve, de alguma forma, o programa residencial, mas voltado exclusivamente para poucos funcionários da Walt Disney Company. Anos mais tarde, 
COLONIAL REVIVAL

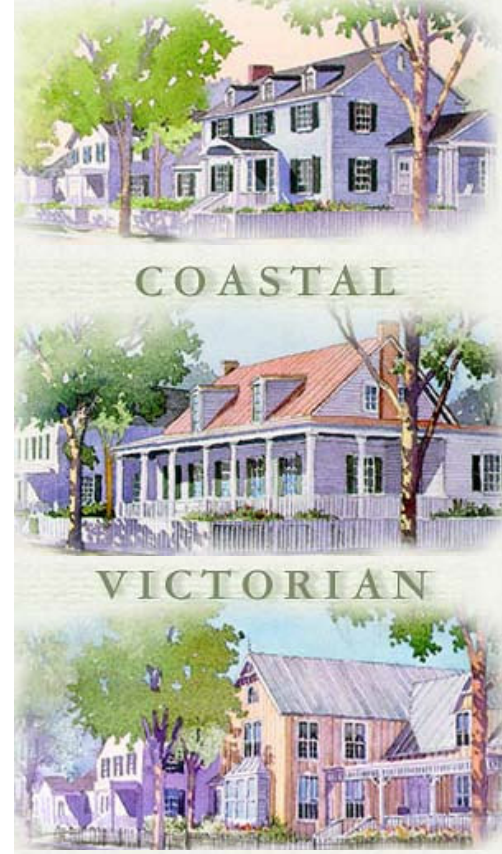

C L A S S I C A L

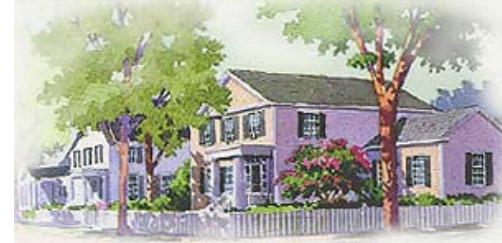

Figs 56, 57, 58 e 59. Alguns dos modelos de casas disponíveis em Celebration. justificada pela idéia original de Walt Disney, foi retomada a tentativa de incluir o programa habitacional dentro dos limites do Reedy Creek. Impovement Disctrict. Desta vez, a idéia era construir uma cidade seguindo os preceitos do New Urbanism. Inaugurada em 1996, Celebration foi concebida pelos escritórios Cooper Robertson \& Partners e Robert A.M. Stern Architects para abrigar em torno de 20 mil habitantes, ocupando cerca de 8 mil unidades, e logo atraiu um público de classe média alta.

A cidade conta, hoje, com uma infra-estrutura que permite que quase tudo seja feito sem grandes deslocamentos, ou seja, um morador pode usar seu carro e sair da cidade apenas uma vez por mês para ir a um grande supermercado, por exemplo. Celebration tem creches, escolas, escritórios, centros esportivos, parques, lagos, bancos, cinema, hotel, correios e comércio de pequeno porte, afinal as grandes lojas multinacionais seriam incompatíveis com o retorno ao passado présubúrbio, fonte de inspiração para os New Urbanistas. Conforme as idéias New Urbanistas, não há uma separação por tipos de uso, o zoneamento permite a coexistência de funções, facilitando o deslocamento interno sem a necessidade de automóveis.

Em termos formais, fica clara a utilização de tipologias históricas, inspiradas na arquitetura norte-americana pré-1940, justificada pela tentativa de recriar a "América do passado”. Celebration oferece opções de residências em seis estilos: Classical, Victorian, Colonial Revival, Coastal, Mediterranean e French, sempre em tons pastéis, com um jardim na entrada, garagem na lateral e localização que permita o deslocamento a pé. Curiosamente, Celebration é uma das poucas regiões da Flórida onde não aparecem as figuras de Mickey Mouse e seus colegas. Os parques temáticos propõem um escapismo da vida cotidiana, e para isso o tema deve ser apresentado de forma incisiva, não deixando espaço para que o visitante pense em qualquer outra coisa. Portanto, ao entrar em um parque temático, o visitante continua na cidade, mas deve pensar que não, que foi transportado para outro local distante de seu cotidiano. Em Celebration o cenário se inverte, o morador está dentro de um complexo de parques temáticos, mas deve crer 
38. MORA, Joe. Disney's Dream Town. In. American Studies Today (online) www.americansc.org.uk/Online/ Celebration.htm que não está, que foi transportado para uma vida cotidiana de maior qualidade. Por isso, as referências adotadas não são personagens de histórias infantis e sim as pequenas comunidades do início do século.

Para garantir a manutenção desta aparência, há um código bastante rígido, de cerca de setenta páginas, que determina, entre outras coisas, que todas as cortinas colocadas nas janelas frontais devem ser brancas ou em tons brancos. $\mathrm{O}$ mesmo vale para as cores das casas. Elas devem ser brancas ou, caso tenham cor, só podem ser iguais à outra casa na mesma rua se houver uma distância mínima de três casas. A grama deve estar sempre bem cortada e uma parte do jardim deve ser ocupada por algo além do gramado. Além de garantir a manutenção da aparência, os códigos também regem a utilização da cidade, determinando, por exemplo, que não pode haver mais de duas pessoas ocupando um único quarto. ${ }^{38}$

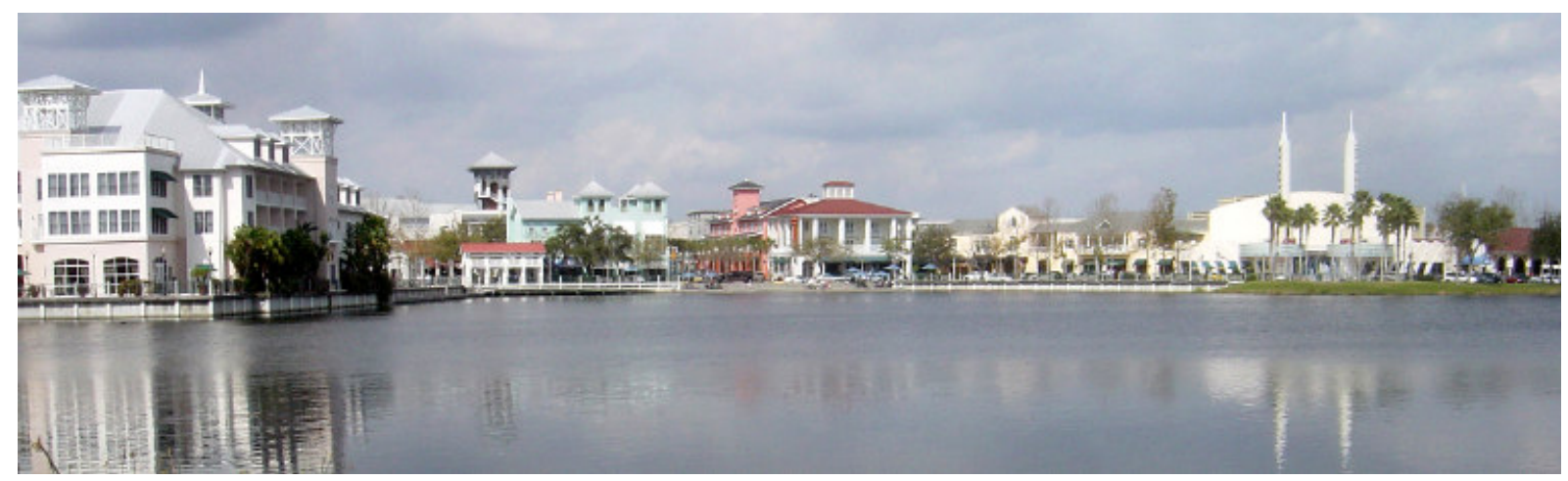

Fig 60. Panorama de Celebration.

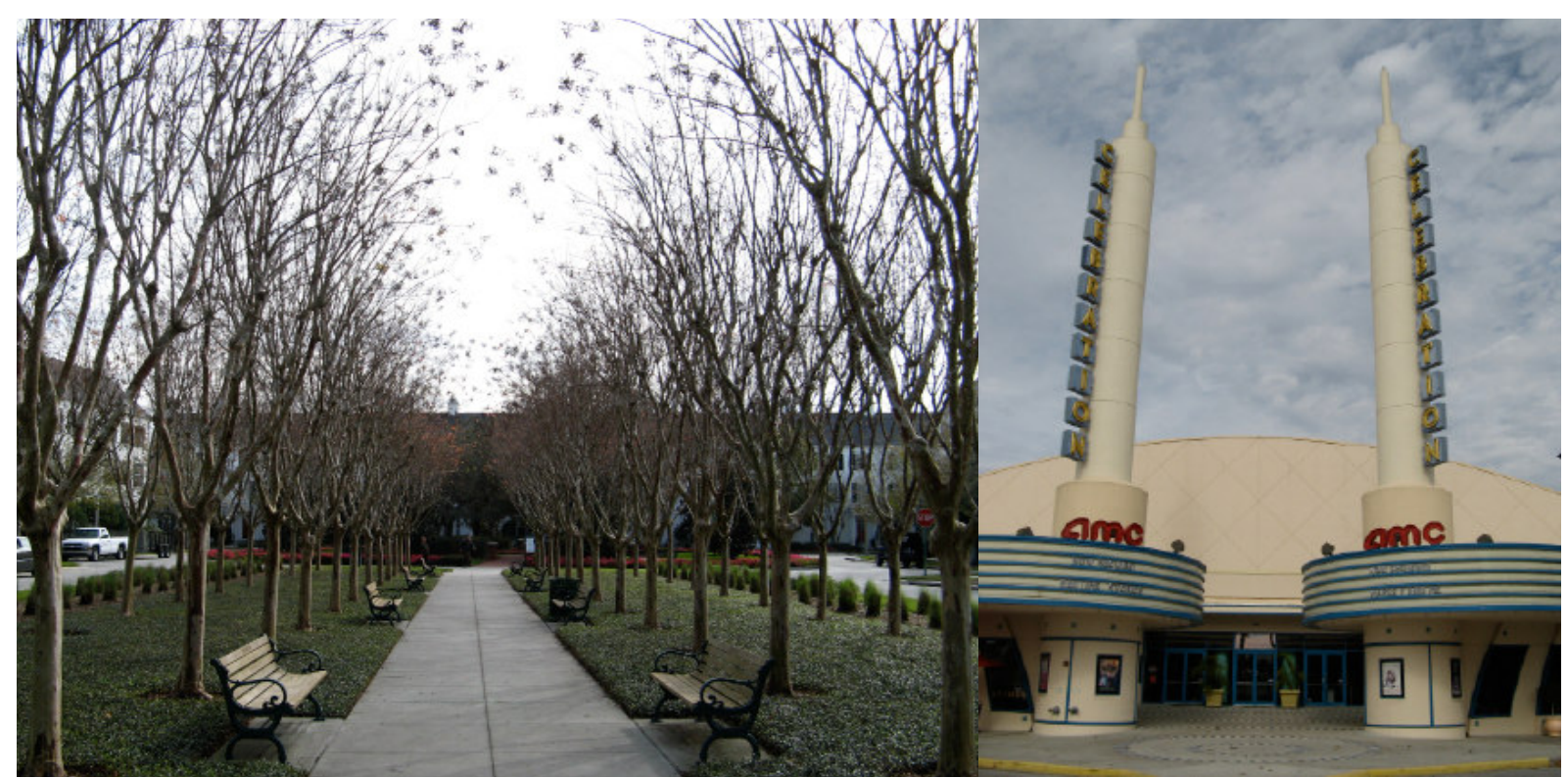

Figs 61 e 62. Praça e cinema em Celebration. 
Há, portanto, uma grande sobreposição entre os espaços públicos e privados, subvertendo a idéia de Jane Jacobs sobre a necessidade de distinção clara entre os dois setores. Embora exista a divisão evidente entre os limites de residências e vias de circulação, e toda a área de ruas, praças e equipamentos seja tratada urbanisticamente como espaço público, trata-se, na verdade, de propriedade privada, pertencente a uma empresa. A Walt Disney Company é proprietária de Celebration e tem autonomia legislativa e administrativa sobre a cidade.

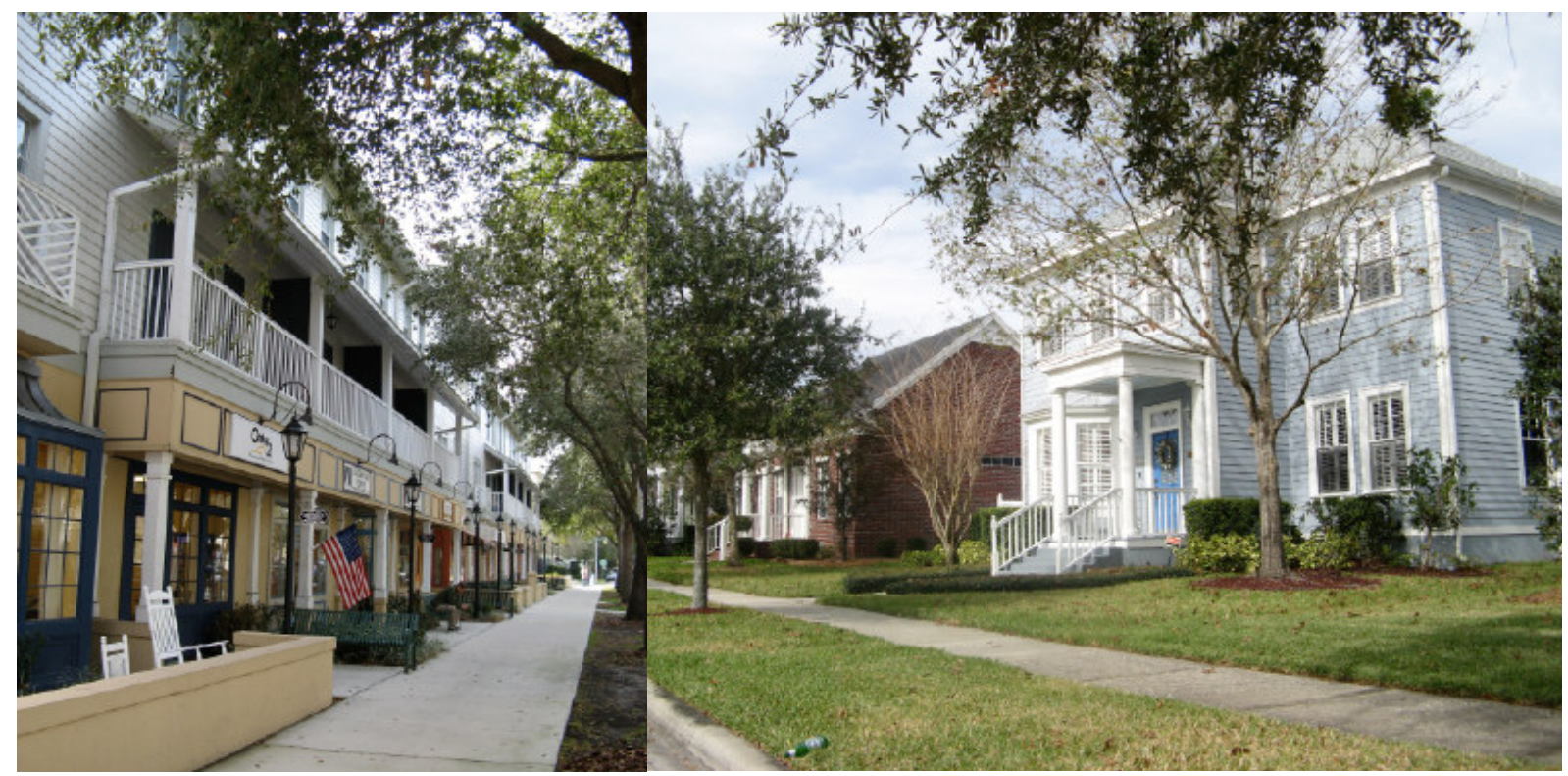

Figs 63 e 64. Construções comerciais e residenciais em Celebration.

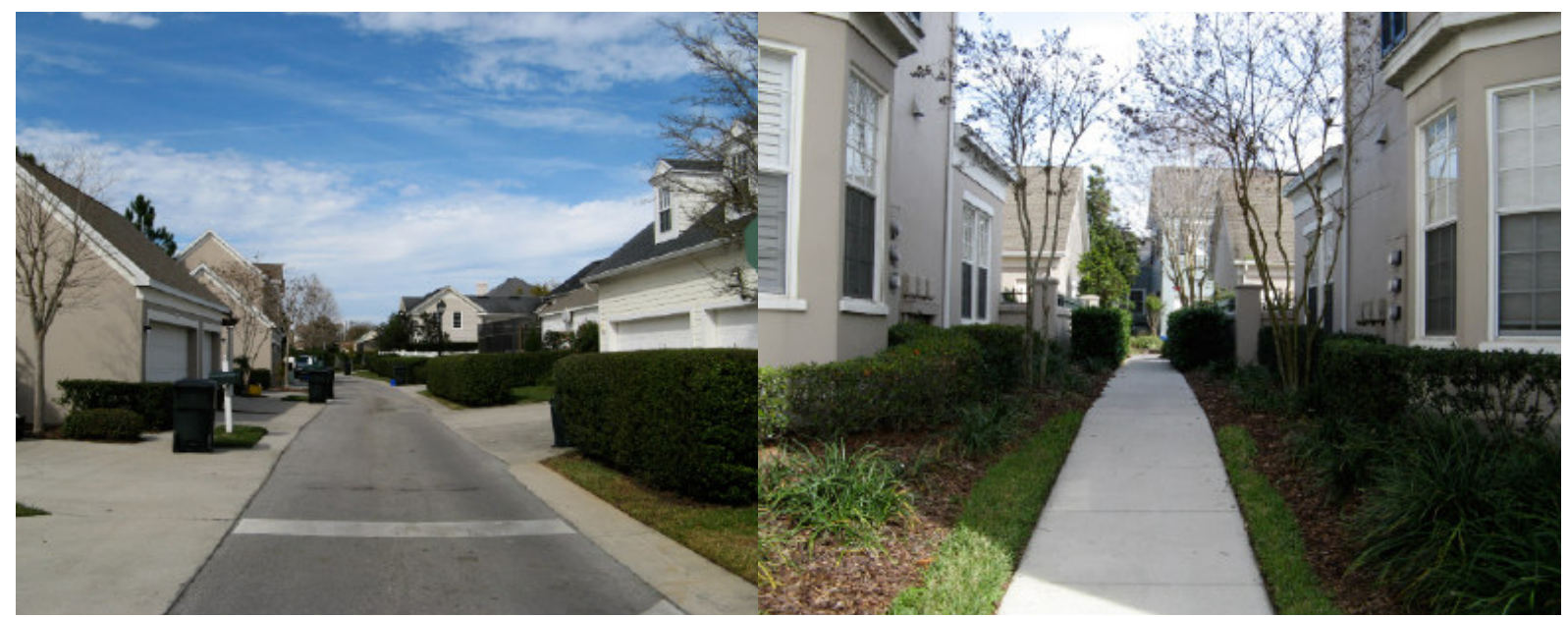

Figs 65 e 66. Via secundária para veículos e via de serviços para pedestres em Celebration.

Ao contrário do que era proposto para EPCOT, em Celebration o morador pode adquirir sua casa, tornar-se proprietário de seu terreno. No entanto, em função do acordo 
feito com o Estado da Flórida, toda a região é administrada pela Disney, o que significa que o morador de Celebration abdica do direito ao voto. Em Celebration não existe prefeito ou qualquer outra organização política democrática, um funcionário da Disney é nomeado para exercer a administração da cidade.

Ainda há espaço para muita discussão em torno do modelo New Urbanista. A garantia de desenvolvimento da cidade após a implantação do projeto seria dada pela criação de associações comunitárias, mas seriam associações de moradores ou uma organização privada, como em Celebration? Essas comunidades e seus equipamentos seriam acessíveis a todos? $\mathrm{O}$ uso de tipologias do passado atenderia às expectativas da população em todos os casos? O New Urbanism parece ser um passo dado em uma direção promissora, mas falta um caminho a ser percorrido para sabermos se as propostas apresentadas se mostrarão eficazes em um escala mais ampla.

Vimos que a inclusão de características formais históricas em projetos de revitalização urbana, ou mesmo de construção de novas cidades, aparece em condições diversas. O New Urbanism, por exemplo, propõe projetar considerando identidades locais. Mas que identidade seria esta? Assim como nas "tradições inventadas" descritas por Hobsbawn ${ }^{39}$, há algo de bastante artificial neste hábito de resgatar o passado. Afinal, a decisão sobre que momento será resgatado implica algum juízo de valor sobre qual teria sido a melhor época e, fatalmente, levará a uma seleção do que será resgatado e do que deve ser esquecido. Portanto, é preciso deixar claro que nenhum revival nos levará de volta a "tempos melhores".

Por outro lado, parece não haver mal em fazer com que a população estabeleça laços de identificação com sua cidade. Mas, para que isso aconteça, o resgate de tradições deve ser condizente com o momento atual. De nada adiantaria retomar um passado já esquecido ou não valorizado pelos habitantes. É preciso que se estabeleça uma identificação positiva, para incentivar a população a manter sua cidade.

Assim, sem dúvida, seria o caminho mais fácil criticar empreendimentos como Seaside, que apresentam uma visão idealizada do passado. Mas e se for essa a referência com a 
qual a população se identifica? Mesmo que esta identidade seja pura influência externa ou idealização, e não condizente com a realidade local, não seria mais artificial resgatar uma espécie de "elo perdido", um momento que nada representa para a população, do que assumir que a população almeja consolidar estas referências ditas artificiais? Se o objetivo é evitar a degradação, então a idéia de atender às expectativas da população em termos estéticos é, certamente, interessante. A dificuldade reside em identificar estas expectativas e aceitar que podem não ser condizentes com a verdadeira história do local.

Percebemos, portanto, que o uso de elementos que remetem ao passado local pode trazer benefícios para todo projeto urbano. Entretanto, é preciso saber identificar quais são os tipos com os quais a população verdadeiramente estabelece esta identificação para que a manutenção seja feita sem a necessidade de imposições, e sim por vontade do usuário em se manter orgulhoso de sua cidade. É necessário um cuidado também para que a tipologia adotada seja condizente com o modo de vida atual, caso contrário os próprios usuários farão, com o tempo, as modificações necessárias para adaptar o espaço a suas condições e o espaço urbano será realmente convertido em cenário descontextualizado.

Ao observar a arte como um fenômeno social, Janet Wolff ressalta a inserção de "elementos extra-estéticos envolvidos no julgamento estético - os valores de classe ou a influ40. WOLFF (1982) p.18. ência de ideais políticos ou morais, por exemplo." ${ }^{\prime 40}$ A aplicação de temas em um projeto pode ser analisada segundo esta perspectiva, pois nada mais é que forma de atribuir-lhe certo valor, que passa a ser mensurável levando-se em conta não mais o apelo estético do objeto ou sua funcionalidade, mas o valor inerente ao tema escolhido. O projeto pode, então, ganhar maior ou menor destaque, de acordo com o sucesso e reconhecimento do tema aplicado no meio sócio-cultural objetivado como público alvo. Determinados assuntos, cujo valor foi atribuído por um grupo em um contexto específico, são transportados para outro contexto, como tentativa de transmitir ao ambiente em questão o valor que carregam consigo. 
Neste sentido, a seleção cuidadosa de determinada corrente estética, desvinculada da cultura local na concepção de cidades, pode ser entendida como temática. Podemos concluir que a transição dos vários modelos de cidades temáticas aqui pesquisados para os espaços temáticos assumidos, voltados para o comércio e lazer, depende de um deslocamento de poder. Se as cidades estudadas refletem o poder do governo vigente, os espaços contemporâneos refletem o poder corporativo, mais característico de nosso tempo. Talvez a última tendência deste fenômeno seja exatamente a justaposição de poderes, apresentada em Celebration, em que marca e governo coincidem. 
1. Oliviero Toscani, fotógrafo publicitário e diretor de criação da Benetton em entrevista aos jornalistas Maurício Stycer e Nelson Blecher. In. BLECHER e MARTINS (1996)

pp. 115-119

\section{Capítulo 4 Marketing e tema}

"- Vc sabe quais são as únicas duas palavras ditas em todo o mundo da mesma forma e que todos entendem?

- Não

- Coca-cola (...) Incrível, não? Todos sabem o que é, que sabor tem, qual a sua cor e como se escreve. Conclusão: somente a publicidade foi capaz de criar o esperanto."

Oliviero Toscani

\section{Introdução}

Neste capítulo será avaliada a relação entre marketing e projetos temáticos, procurando demonstrar, sob a ótica do marketing, o porquê do uso do tema em situações tão distintas quanto lojas, parques, museus e cidades. Se estabelecimentos comerciais passaram a adotar o modelo temático como meio de atrair o consumidor, certamente foi porque, no campo do marketing, havia uma movimentação em direção a uma publicidade mais visual e lúdica. Portanto, se o tema passou a ser incorporado como elemento fundamental de divulgação de estabelecimentos diversos, muito se deve à difusão de uma cultura de maior visualidade. A primeira parte deste capítulo pretende, então, mostrar como a linguagem visual mais direta, com personagens e outros elementos figurativos, vem sendo utilizada em termos de marketing. Além disso, procuramos explicar este uso mostrando como cresceu a busca pelo lazer enquanto produto consumível.

Em seguida, veremos como o tema é explorado na promoção de destinos turísticos, sejam eles estabelecimentos menores ou cidades inteiras, já que em ambas as situações a temática agregada à concepção arquitetônica funciona como parte de um projeto de marketing de lugar. Já há autores defendendo que cidade inteiras, ou mesmo países associados a determinada identidade poderiam atrair tanto o turismo quanto desenvolvimento econômico e, conseqüentemente, social.

4.1 $O$ uso do temático na arquitetura não é, definitivaMarketing na cultura mente, um fenômeno isolado. Sua difusão está relacionada a visual contemporânea uma cultura cada vez mais visual que exige apreendimento 
2. ARIÈS (1981) pp.43-63. ças quanto adultos, os bibelôs, fantoches e marionetes. ${ }^{2}$ Em um primeiro momento do século XX, os brinquedos são, em sua maioria, confeccionados pelas próprias crianças - bonecas de pano, carrinhos de madeira, amarelinha, etc - até que as fábricas passam a produzir bonecas de massa e outras peças industrializadas. Logo, acompanhado a Revolução industrial passam a ser utilizados materiais mais leves, como plástico e 3. www.estrela.com.br/estrela vinil. $^{3}$

rápido, muitas vezes superficial, de informações. É preciso, então, avaliar como esta visualidade e mesmo ludicidade vêm permeando recentemente outros campos, em especial nos casos da comunicação e marketing, que influenciam diretamente a transposição do temático para a arquitetura comercial.

A consolidação do consumidor infantil pode ter sido uma das grandes influências para que o temático migrasse dos parques para uma gama crescente de estabelecimentos. Phillipe Ariès, mostra, ao revisitar a biografia de Luis XIII enquanto menino, que, até o século XVII, não estava claramente estabelecido o conceito de infância. Após a fase mais frágil do bebê, a partir do momento em passa a andar, a criança é vista simplesmente como um adulto pequeno, ganhando responsabilidades progressivas. Nesse momento, a restrita brincadeira com peões, cavalos de pau e bonecas era associada a jogos de adultos, até que, por volta dos sete anos, não fosse feita qualquer distinção entre criança e adulto. Ao longo dos séculos XVIII e XIX, aparecem brinquedos voltados tanto para crian-

(c)

Entretanto, a partir da década de setenta, a criança começa a ser vista como consumidora, recebendo oferta de brinquedos com atrativos variados. O documentário "Peque-

4. Documentário exibido em 07 de agosto de 2008 no canal à cabo GNT. nos Grandes Consumidores", produzido pela rede canadense $\mathrm{CBC}$ demonstra como nas ultimas quatro décadas a figura do consumidor passa a ser representada por pessoas cada vez mais novas, a ponto de, hoje, os profissionais de marketing enxergarem pequenos consumidores mesmo em bebês ainda nem nascidos.

Segundo o documentário, a partir da década de setenta começa a ser percebida a influência da criança na decisão de compra da família, inclusive em produtos não infantis. Neste momento, para atrair o público infantil os comerciais de 


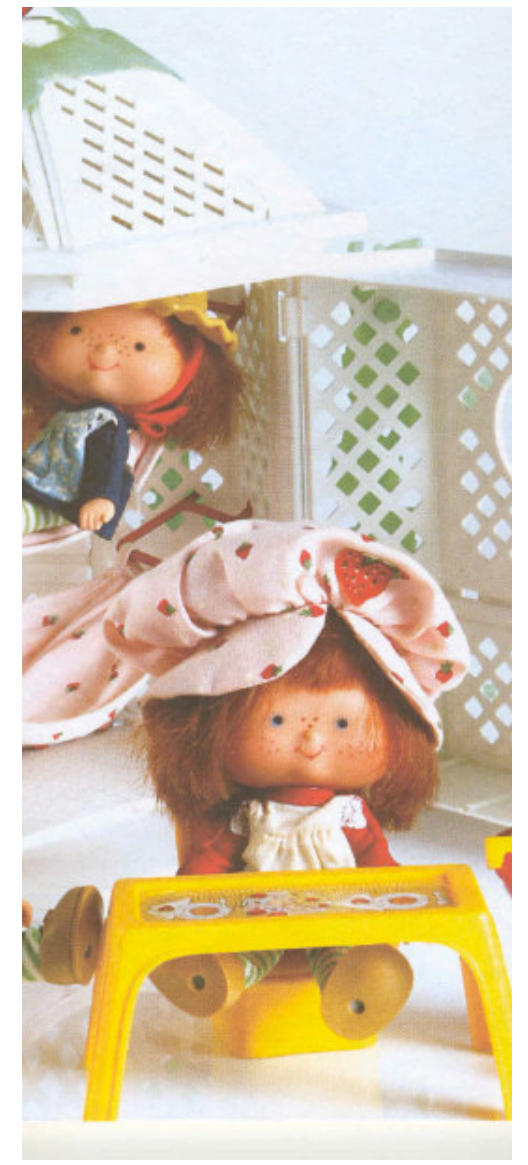

Fig 1. Coleção Moranguinho
TV passam a mostrar crianças, apresentando cada vez menos adultos. Os comerciais incorporam a linguagem dos desenhos animados em uma narrativa assimilável facilmente pela criança. Já na década seguinte, o marketing se volta realmente com foco para o novo publico consumidor, estudando a fundo as preferências infantis. O documentário chega a ressaltar consultorias especializadas em realizar pesquisas de mercado com crianças. São criados nesta época os primeiros desenhos animados pensados exclusivamente com o intuito de vender produtos licenciados, chegando a ser chamados "comerciais de longa duração”, como 'He-Man', 'Moranguinho', 'Ursinhos Carinhosos', etc. Se antes havia um ou outro brinquedo que fizesse referência a personagens conhecidos, agora a idéia do brinquedo precede o desenho animado, criado justamente para promover os futuros produtos licenciados.

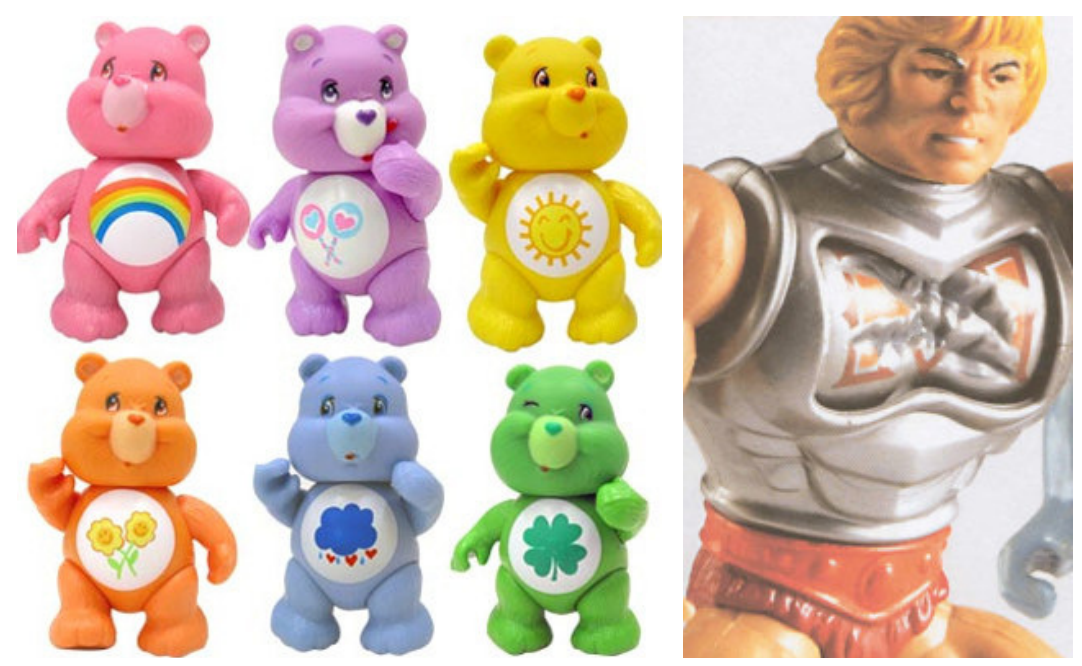

Figs 2 e 3. Bonecos dos Ursinhos carinhosos e He-man

Há uma demanda em aberto para este tipo de produto já que a entrada da mulher no mercado de trabalho e o aumento na taxa de divórcios fazem com que os pais tenham menos tempo com os filhos, gerando uma "culpa", muitas vezes suprida com maior generosidade no ato de presentear. Este mercado pode ser preenchido tanto com a produção de bonecos, jogos e demais brinquedos, quanto com a venda de experiências associadas aos personagens, algo intimamente relacionado aos parques temáticos.

De fato, a Disney foi a primeira grande empresa a apostar no sistema de cross reference, em que cada produto é, além de produto em si, propaganda de produtos relacionados. Afi- 
5. The Disney Management Style (Walt Disney Productions, 1977) p.18. In.

FJELLMAN (1992) pp.151-152.

"The continued success of

Disney organization requires the perpetuation of a delicate balance of functions. Every function is dependent upon other functions. All are independent. None stands alone. We have the parent company that brenchs out into subsidiary companies, divisions, departments, and other functions; and though we're diversified, each subsidiary is related to the same corporate product... "The Finest in Family Entertainment" This is what we call the Disney Synergy."

6. HOLLIS, Richard. SIBLEY, Brian. The Disney Studio Story. New York: Crown, 1988. p.134 In FJELLMAN (1992) pp.157-158. "Whistle While You Work", "Hey Ho", "Some Day my Prince Will

Come", I'm Wishing", and all the other songs have sold millions of records over the years. Books, comics, games, toys and other merchandise based on Snow White have sold millions of units. Millions of people have enjoyed the Disneyland attraction reliving Snow White's Adventures, and an untold multitude of people have marveled at the ice shows and stage shows in which characters from Snow White have appeared around the world. This is the Disney Diversity in action.'

7. Idem

8. www.amazon.com nal, a Walt Disney Company administra a propaganda de subsidiárias, parques temáticos, filmes, séries de TV e produtos baseados em seus personagens. Internamente, o sistema foi chamado Disney Synergy, conforme relata o manual da empresa, de 1977:

\begin{abstract}
"O contínuo sucesso das organizações Disey requer um perpétuo e delicado equilíbrio de funções. Cada função depende das outras funções. Todas são independentes. Nenhuma se sutenta sozinha. Nós temos a companhia mãe que se ramifica em subsidiárias, divisões, departamentos e outras funções; e, ainda que sejamos diversificados, cada subsidiária se refere ao mesmo produto corporativo... "O melhor do entretenimento familiar". Isso é o que chamamos Disney Synergy."
\end{abstract}

Assim, é estabelecida uma relação em que os filmes são, além de filmes, propaganda dos parques temáticos e produtos, da mesma forma em que o inverso é verdadeiro. Desta maneira, o produto filme ganha longevidade, gerando lucro por tempo indefinido. Stephen Fjellman apresenta como exemplo o primeiro longa metragem produzido pelos estúdios Disney, "Branca de Neve", lançado em 1937. "Whistle While You Work", "Hey Ho", "Some Day my Prince Will Come", I'm Wishing", e todas as outras músicas venderam milhões de discos ao longo dos anos. Livros, quadrinhos, jogos, brinquedos e outros produtos baseados na Branca de Neve venderam milhões de unidades. Milhões de pessoas se divertiram na atração da Disneyland que recria as aventuras da Branca de Neve, e uma incontável multidão se maravilhou com os shows no gelo e shows em que os personagens de "A Branca de Neve" apareceram, no mundo todo. Isso é a diversidade Disney em ação."

Em 1987, o relançamento comemorativo dos 50 anos do filme rendeu, só no mercado americano, 40 milhões de dólares em oito semanas, complementando os 47 lucrados ate então. ${ }^{7}$ Entretanto, a continuidade do mercado explorado pelo filme pode ser vista ainda hoje. A busca por 'Branca de Neve' no site de vendas internacional $A_{\text {mazon }}^{8}$ mostra como o tema permanece explorado em variadas frentes. A quantidade de 
9. www.submarino.com.br

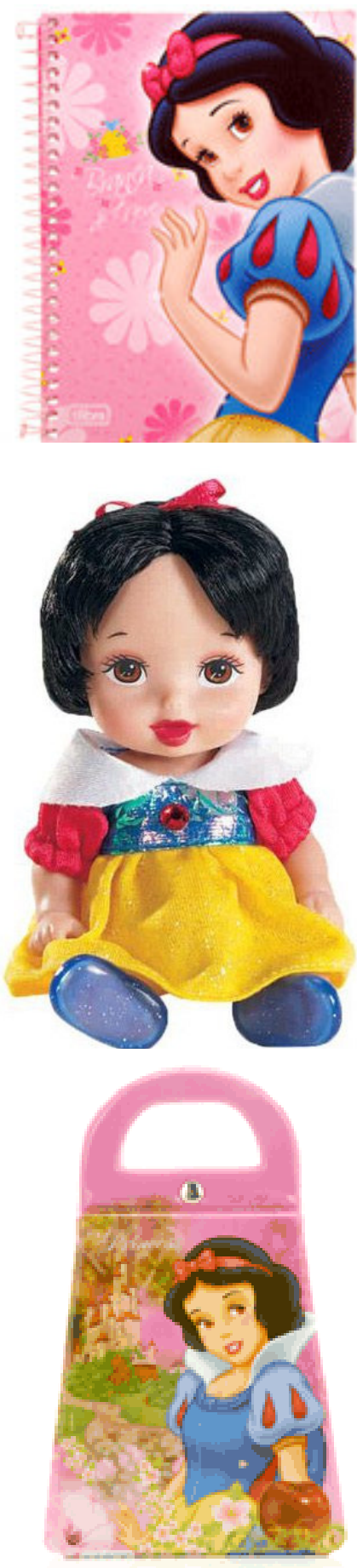

Figs 4, 5 e 6. Caderno, boneca e bolsa com a Branca de Neve.

10. www.nettv.globo.com produtos relacionados é tal que apenas no departamento de brinquedos são encontrados 705 itens. Uma rápida pesquisa em seu equivalente brasileiro, Submarino ${ }^{9}$, retorna nada menos que 288 produtos, entre brinquedos, livros, CDs, DVDs, roupas, itens de papelaria e outros.

Portanto, encontramos antes na Disney e seus parques, muitas das características exploradas pelo marketing voltado para o público infantil nas últimas décadas. No entanto, até 1984, justamente a época em que surgem os chamados "comerciais de longa duração", a Disney não utilizava os meios convencionais para anúncios, contanto apenas com o sistema auto-referencial e a propaganda "boca-a-boca". Para se ter uma idéia de como este sistema foi eficiente, até então a empresa não possuía qualquer orçamento ou cota para investimento em marketing. Logo a Disney passou a adotar o novo modelo.

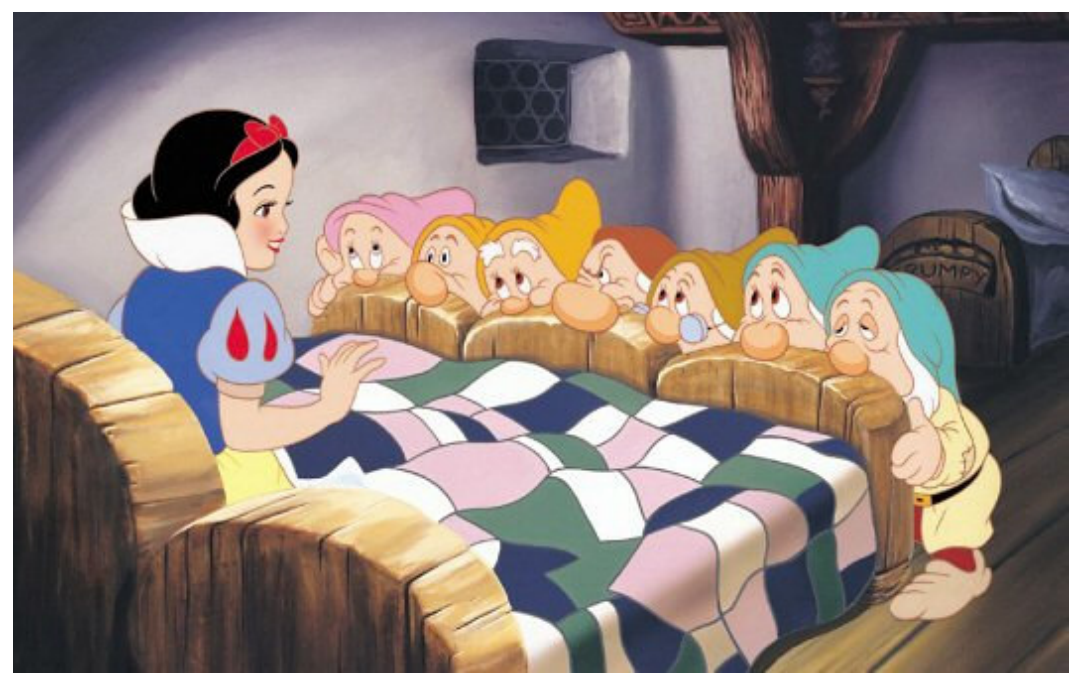

Fig 7. Cena de "A Branca de Neve".

Por volta da década de noventa, a fronteira do consumidor infantil é ainda mais esticada, com o crescimento da quantidade de produtos voltados para bebês e, em seguida, o desenvolvimento de emissoras e programas de televisão direcionados para o público de zero a três anos, antes alheio ao processo de compra. No website da operadora de TV por assinatura NET TV, o canal Discovery Kids, voltado ao público pré-escolar, é apresentado como o "canal que desperta o interesse das crianças para o conhecimento, estimulando sua capacidade de aprendizagem por meio da curiosidade, exploração e diversão."10

O documentário "Pequenos Grandes Consumidores" 
11. GIACOMINI FILHO (1999)

p.25.

12. PACKARD, Vance. A nova técnica de convencer. São Paulo: IBRASA, 1965. In GIACOMINI FILHO (1999) p.34.

13. www.fiftiesweb.com/tv/davycrockett.htm

14. SOUZA, Francisco Alberto Madia de. Quem nunca fumou está comprando isqueiro. Marketing Now.

São Paulo: Midia e Associados, ano 4 n.22, p.2, mar 1996. In GIACOMINI FILHO (1999) p.35

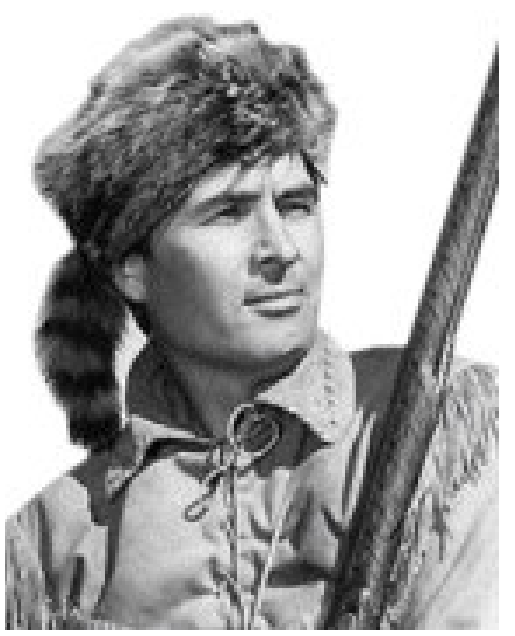

Fig 8. Davy Crockett

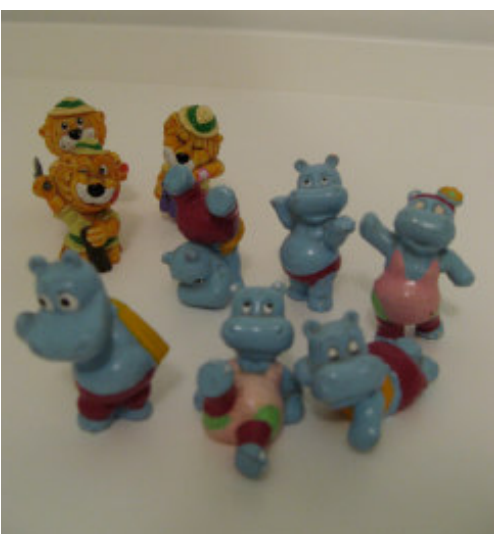

Fig 9. Brinquedos Kinder Ovo afirma que, atualmente, $76 \%$ dos lanches e $62 \%$ das compras da casa são decididos por crianças. Com a conversão do público infantil em consumidor há um enfoque maior da publicidade em peças promocionais de apelo lúdico, dentre elas o incentivo ao colecionismo ou coleção, definido por Giacomini como uma “(...)reunião de objetos empreendida por pessoas, com a finalidade de atender às necessidades psicossociais." 11 Giacomini identifica que, com a competitividade crescente por mercados, o marketing vem buscando no colecionismo uma alternativa de promoção e diferenciação de produtos.

Embora não tenha encontrado nenhum registro histórico que posicionasse o início do uso do colecionismo como promoção, o autor encontrou exemplos datados de 1955, quando a mania por Davy Crockett, personagem de um programa da Disney, gerou cerca de 300 produtos. ${ }^{12}$ Se hoje é bastante comum a venda de produtos relacionados a séries de TV, o programa foi pioneiro ao vender cerca de 100 milhões de dólares em produtos, especialmente chapéus de pele de guaxinim. ${ }^{13}$ Giacomini relata ainda que, na década de 80 , enquanto o consumo de cigarros caía, as vendas de isqueiros da marca Zippo aumentavam, chegando a dobrar entre 1988 e 1994. A explicação era simples, o público passara a colecionar o isqueiro cuja marca, referência desde a década de 50, tornara-se simbólica de status. A marca passou, então a lançar coleções especiais e edições comemorativas, incentivando o hábito, mesmo para não fumantes. ${ }^{14}$

O autor mostra que a promoção do colecionismo constitui estratégia relacionada diretamente ao público infantil, para quem a coleção estaria ligada tanto à conservação de lembranças quanto à possibilidade de interação social. Pensando neste público, uma série de marcas vem promovendo coleções, seja como brindes que incentivam a compra de determinado produto, seja promovendo os próprios produtos colecionáveis. A Coca-cola promove brindes colecionáveis, desde o sucesso alcançado pelas miniaturas reproduzindo garrafas do refrigerante em línguas diferentes, promoção iniciada em 1988. A italiana Ferrero Rocher, comercializa desde 1978, no Brasil desde 1994, o Kinder Ovo, chocolate que inclui em seu interior um pequeno brinquedo colecionável. A cada ano é lança- 
15. www.ferrero.com.br

16. CRIANÇA: o consumidor que mais cresce no país. Mídia \& Mercado, São

Paulo: Meio e Mensagem, ano 2, n.10 pp.14-19, 15 jan. 1996. In GIACOMINI FILHO (1999) p.38.

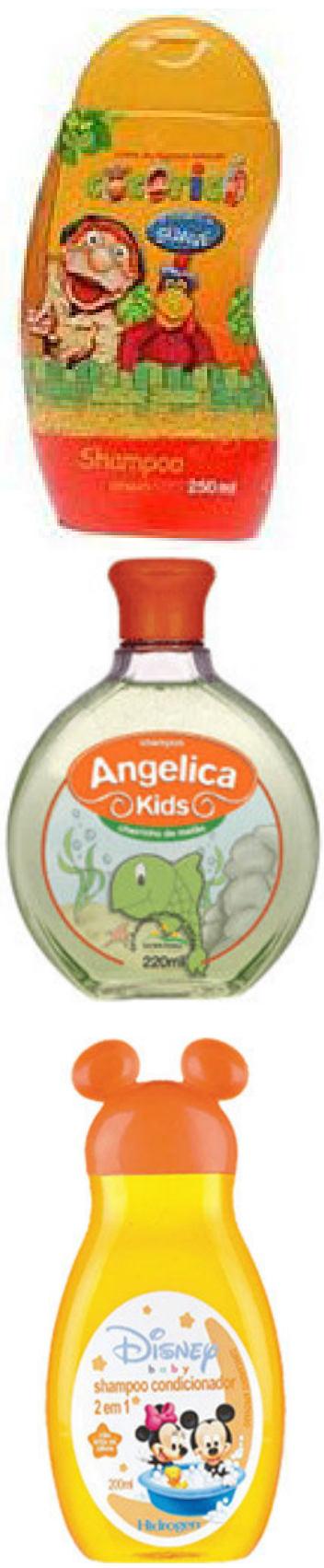

Figs 10, 11 e 12. Shampoos infantis do Cocoricó, Angélica e Disney.

17. A Herança do pai da turma da Mônica. In. Revista Exame edição 0851 Editora Abril. Disponível em http://portalexame.abril.com. br/revista/exame/edicoes/0851/ negocios/m0057371.html da uma nova coleção de brinquedos de inegável apelo para o público infantil, e no mundo todo há colecionadores. ${ }^{15}$

A fábrica brasileira de brinquedos Glasslite seguiu, durante as décadas de 80 e 90, a linha dos "comerciais de longa duração", associando-a ao colecionismo. Buscando burlar a crise instituída com a chegada dos brinquedos importados, a empresa passou a comercializar os heróis da TV - Rambo, Tartarugas Ninja, Cavaleiros do Zodíaco - acompanhados de acessórios vendidos à parte. Minoru Wakabayashi, chefe de marketing da empresa justificava a estratégia afirmando: "Vendemos fantasia"."16

Assim, pensando no maior poder de decisão do público infantil no ato da compra, muitos produtos não necessariamente voltados para este público remodelaram embalagem e incluíram referências infantis ou brindes para incentivar a criança enquanto agente comprador. Cada vez mais personagens infantis são associados a produtos, podendo hoje a criança escolher se toma banho com o shampoo da Mônica, da Angélica, das princesas Disney, do Mickey, do Senninha ou com uma infinidade de personagens disponível. A Turma da Mônica, famosa nos quadrinhos de Maurício de Souza, estampa embalagens e propagandas de produtos que vão de fraldas a hambúrguer ou impermeabilizantes. Segundo reportagem publicada na revista Exame, até 2005 o setor de licenciamentos era responsável por $62 \%$ do faturamento da Mauricio de Souza Produções, o maior licenciador de produtos no Brasil, com cerca de 2000 itens. $^{17}$

Dentro deste contexto, faz todo sentido que o temático extrapole a fronteira dos parques, trazendo aspectos lúdicos para estabelecimentos diversos, e mesmo para cidades turísticas inteiras, afinal as férias e momentos de lazer também são decididas em função da criança. Ao mesmo tempo, estas ao se reconhecerem enquanto consumidoras com poder de decisão já não desejam apenas um passeio pela Disneyland, querem o mesmo que os adultos, levando inclusive ao surgimento de resorts de férias exclusivos para crianças, evidentemente com as restrições impostas pela lei, mas com todas as facilidades tradicionais dos resorts para adultos - entretenimento, bares molhados, massagens e serviços diversos. Serviços até pouco 
18. Bonequinhas de luxo. Revista

Marie Claire. Rio de Janeiro: Ed Globo, 2004. Edição 157. pp.115

118.
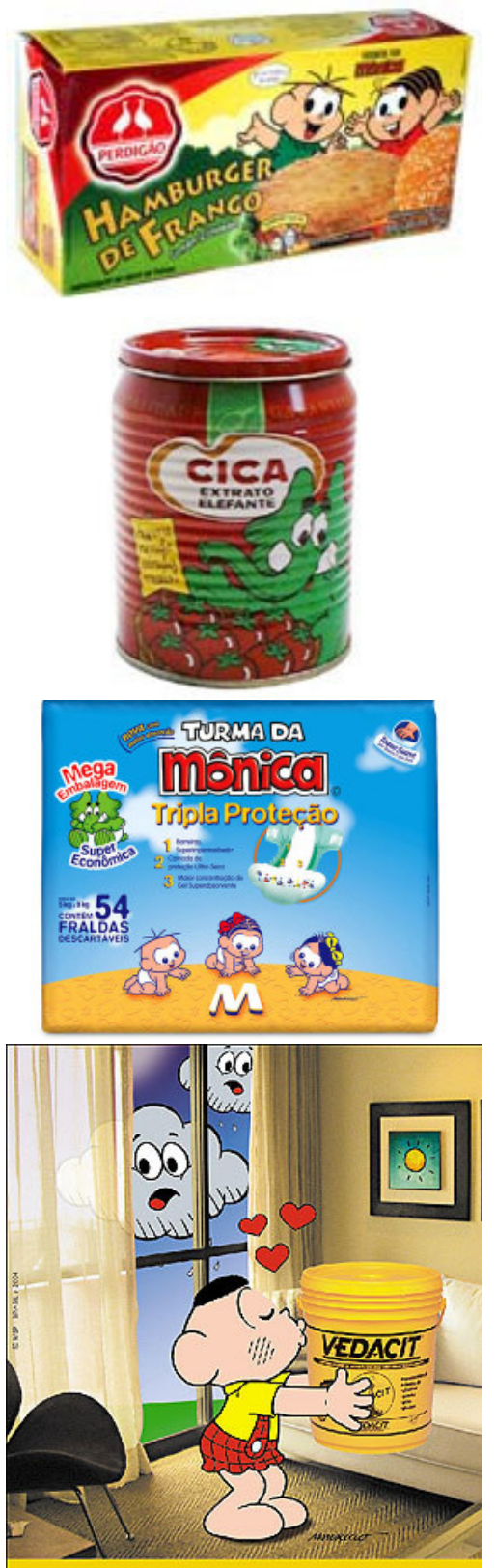

Vedacit na massa, a água não passa. VEDACIT

Figs 13, 14, 15 e 16. Hamburguer, extrato de tomate, fralda e impermeabilizante com a Turma da Mônica.

19. Lost Terceira Temporada Completa. Buena Vista Home Entertainment, 2007. (989 min)

DVD 7 vol.

20.POSTMAN (1986) tempo restritos ao público adulto, como salões de beleza, já descobriram o filão. Uma recente diversão para meninas de classe média em grandes centros é a comemoração de aniversários em salões de beleza, onde a aniversariante e suas amigas são recebidas e tratadas como mulheres. Os pacotes podem incluir maquiagem, penteado, banho relaxante e massagem. ${ }^{18}$

Parece claro, portanto, que, ao atrair o público infantil, este trará consigo o público adulto, levando ao aumento de consumo de determinado produto ou serviço. Nesta linha de raciocínio podemos encontrar uma das razões pelas quais o temático tenha sido tão explorado nas últimas décadas. Se, por um lado, houve necessidade de tornar produtos atraentes para este público infantil recém surgido, por outro, parece que o próprio adulto passou a pautar muitas de suas escolhas influenciado pela ótica infantil, justificando a crescente ludicidade dos espaços comerciais.

Se há uma crescente participação do público infantil no mercado consumidor, ao mesmo tempo percebemos um interesse maior do público adulto em produtos antes exclusivamente infantis, como brinquedos. Um mini documentário incluído no DVD da terceira temporada da série de TV Lost, da rede norte-americana $A B C$ - não por acaso parte do grupo Disney - mostra adultos lotando a Toys R'Us, maior loja de brinquedos de Nova York, em busca de bonecos dos personagens da série no dia de seu lançamento. ${ }^{19}$ Estes produtos são como os bonecos vendidos para crianças, são vendidos em lojas de brinquedos voltadas para crianças, mas têm enfoque no público adulto, mesmo porque a recomendação etária para a série, ao menos no Brasil, varia entre não recomendado para menores de dezesseis ou dezoito anos, dependendo da temporada.

Assim, percebemos mesmo no mundo adulto, uma constante busca pelo entretenimento cada vez mais intenso, fenômeno já analisado por Neil Postman, para quem vários elementos culturais agora giram em torno do show business, fazendo com que estejamos no limite de nos divertimos até morrer, conforme o titulo de seu livro: "Amusing Ourselves to Deatb" ${ }^{20}$. Para o autor, várias cidades norte-americanas foram símbolos de épocas diferentes e Las Vegas, justamente uma das mecas do temático, seria a cidade símbolo de nosso tempo, 

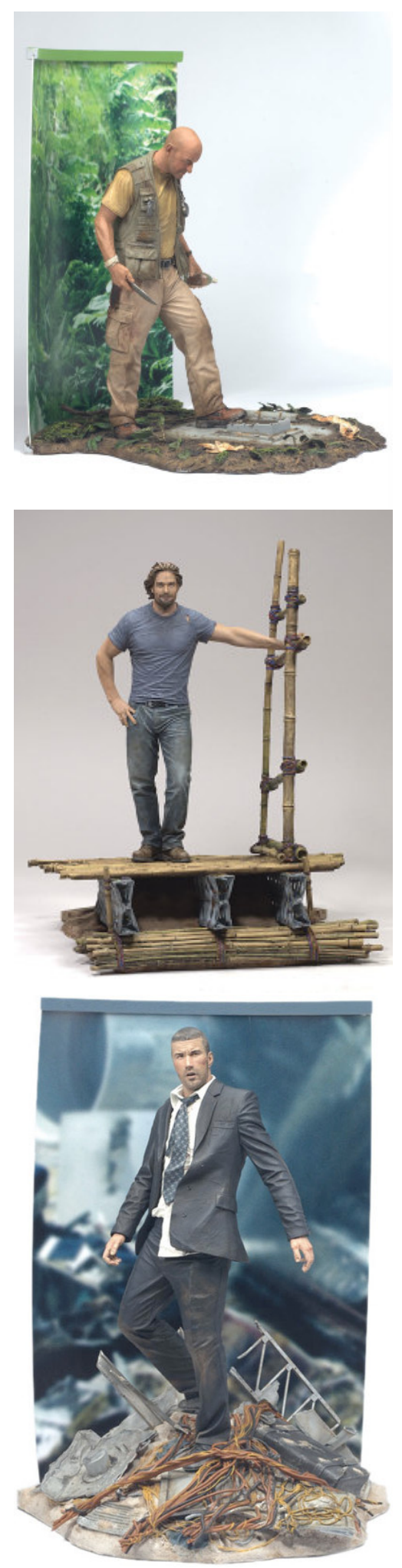

Figs 17, 18 e 19. Bonecos para adultos da série de TV Lost. pois gira em torno do lazer, representa um momento em que o

21. Idem pp.3-4. discurso público se dá sob a forma do entretenimento. ${ }^{21}$

Postman supõe que a mídia disponível para cada cultura afeta sua formação. Assim, considerando que o formato do discurso tem influência determinante no significado a ser transmitido, associa a consolidação da TV como o principal meio de comunicação vigente com uma cultura de maior visualidade. O conteúdo que já fora transmitido, inclusive por telégrafo, teve de se adequar ao novo meio - a TV. Para compreender a teoria analisada, é preciso diferenciar a mídia e a tecnologia. A tecnologia é o aparato físico; a mídia, o uso dado a ele. A TV pode, em certos locais, utilizar a mesma tecnologia, mas não ser a mesma mídia. Isso ocorre em locais onde a TV não é $24 \mathrm{~h}$, sem comerciais, está prioritariamente a serviço do governo e funciona quase como um rádio, com a principal imagem sendo de "cabeças falantes". Postman fala da TV como mídia, não como tecnologia.

No período que o autor chama de era tipográfica, os anúncios eram inicialmente argumentativos, textos em jornais explicando porque certo produto ou serviço seria útil e como funcionava. Não se sabe se os argumentos e explicações eram verdadeiros, porém o que importa aqui é a forma de estruturar a propaganda. Somente no final do XIX apareceram slogans e imagens como forma de convencimento.

A invenção do telégrafo fez com que a transmissão de informações deixasse de estar vinculada à velocidade humana. Por outro lado, não só permitiu a troca de informações entre locais distantes como praticamente obrigou esta troca a ser realizada. O resultado seria a transmissão de uma série de informações desconectadas entre si e com o público. Pela primeira vez o homem passou a receber notícias que não tinham qualquer relação com suas decisões. Surgiam as notícias do dia que, na TV, seriam convertidas em uma colagem contínua de acontecimentos associados a imagens de apreensão rápida. Posteriormente a invenção da fotografia somou-se ao telégrafo, trazendo uma identificação para a notícia, ou seja, imagem e informação se referenciavam, porém não traziam qualquer referência ao leitor.

A televisão seria uma espécie de continuação para 
22. HUXLEY (2001)

23. ORWELL (2003)

esta história, em que a escrita não será extinta, mas tem sua compreensão alterada pelo surgimento do novo meio. Hoje, todo o uso de outras mídias é orientado pela TV, que informa que livros ler, que telefone usar ou mesmo como fazer uso do computador. Ela se tornou, nas palavras de Roland Barthes um "mito", ou seja, algo que não é nunca questionado, que se torna natural e invisível. A discussão atual está centrada naquilo que é transmitido pela TV, e não em sua existência e implicações. Ela é a nossa cultura e, por comportar qualquer tipo de assunto, transforma nossa cultura em uma grande arena para o show business. Segundo o autor, é possível que ao final da leitura estejamos convencidos de que está tudo bem e de que a TV é ótima e era esse o medo de Huxley ${ }^{22}$. Se Orwell ${ }^{23}$ temia que livros fossem proibidos, Huxley temia que não existissem mais por não haver ninguém interessado.

A verdade está intimamente ligada à forma de expressão. Cada cultura pensa que a verdade estará mais precisamente exposta em um meio. Para os economistas, através de números, por exemplo, ou para os sofistas através da retórica, para os acadêmicos através da escrita, e assim por diante. Dependendo da situação e da época, frases como "seeing is believing", "saying is believing", "reeding is believing", "counting is believing", etc, tiveram maior ou menor credibilidade. A idéia de inteligência vem em cada época associada à maior capacidade de falar, ler, calcular, deduzir, ou seja de agir de acordo com a melhor forma possível de transmissão da verdade. Assim, os conceitos de verdade e inteligência teriam sido modificados com a passagem do mundo impresso para um modo em que 24. POSTMAN (1986) pp.20-27. impera a nova mídia tecnológica. ${ }^{24}$

Postman traça um paralelo entre a passagem da linguagem oral para a escrita e a transformação pela qual estaríamos passando - da linguagem escrita para a eletrônica. Seria, também, uma mudança na forma de estruturar o pensamento e uma mudança cultural para nossa sociedade. As linguagens são estruturadas por metáforas, sendo as metáforas "eletrônicas" muito mais sutis, menos explícitas. Estas metáforas seriam o conteúdo da nossa cultura, considerando que a definição de verdade deriva, ao menos em parte, da mídia em que a mensagem é veiculada. Postman usa a definição de 
25. FRYE, Northrop. The Great code: The Bible and literature. Toronto: Academic Press, 1981. p. 217 In. POSTMAN (1986) pp.17-19. ressonância de Northrop Frye ${ }^{25}$, segundo a qual uma afirmação em um contexto particular acaba ganhando significado universal. No exemplo citado, Atenas significaria excelência intelectual e Alice uma metáfora para a busca por ordem em meio a um mundo de nonsense. Neste sentido, os meios de comunicação têm o poder de levar a mensagem para além do contexto, construindo relações metafóricas.

$\mathrm{O}$ autor faz associação com a teoria de McLuhan para quem cada meio possibilita um modo único de discurso - o meio é a mensagem. Nós estaríamos, portanto, no processo de conversão do meio centrado na palavra para o meio centrado na imagem. No entanto, Postman alerta que devemos ter cuidado para não confundir a 'mensagem' de McLuhan com o que chama 'metáfora'. Seja qual for a mídia, a mensagem hoje não é direta, objetiva e sim substituída por metáforas que 26. POSTMAN (1986) pp.13-15. “colorem, aumentam, diminuem, etc.” o mundo para nós. ${ }^{26}$

Com isso, não pretende criticar a TV, ao contrário, diz que aprecia seu conteúdo junk; o problema aparece quando a TV se propõe a transmitir sérias discussões culturais, o que, ironicamente, os intelectuais lhe pedem para fazer. Portanto, não pretende ignorar que a TV pode trazer benefícios, mas quer provar que trouxe uma queda na seriedade, clareza e valor do discurso público. Traçando novamente uma comparação com a tipografia, identifica que ambas teriam trazido mais benefícios mas, também, alguns prejuízos. Além disso, não pretende considerar que a TV traz alterações na capacidade cognitiva do homem e sim em seu discurso.

A TV americana faz muito sucesso em todo o mundo, com muitos programas exportados, porque está totalmente devotada a oferecer entretenimento. No entanto, isso é quase óbvio, nem seria alvo de qualquer questão. O que Postman questiona não é o fato da TV ser entretenimento, e sim de apresentar todo e qualquer fato como entretenimento. Mesmo os noticiários trazem música, cor, pessoas bonitas, tudo leva a crer que as notícias não devem ser levadas a sério. Assim, assistimos assassinatos, guerras e tragédias e ligamos a TV de novo no dia seguinte, na certeza de que o noticiário é para entretenimento, não para informação.

O autor conclui dizendo que a nossa cultura se direcio- 
27. Idem pp.100-113.

28. ARANTES, Otília Beatriz Fiori. Arquitetura Simulada. In. NOVAES

(2003) na para uma nova forma de resolver suas questões, principalmente questões relevantes, já que discursos mais complexos não teriam espaço na TV. A natureza do discurso torna cada vez mais tênue o limite entre o que é e o que não é show business. Inúmeras vezes, a TV traz uma série de pseudo-informações descontextualizadas, em que as manchetes são apresentadas de forma rápida, sem qualquer relação com as notícias precedentes ou que seguem. A TV é o principal meio para que nos informemos sobre nossa cultura e, então, a forma como apresenta o mundo se torna um modelo para como o mundo deve ser mostrado. Com isso, cresce a preferência do público por imagens dinâmicas. A linguagem televisiva, dominante em nosso tempo, estaria sendo transposta para outras mídias, caso do citado jornal impresso americano USA Today. Assim, é através da imagem, do entretenimento, que passamos a nos comunicar no cotidiano. ${ }^{27}$

Sobre esta predominância da cultura visual, Otília Arantes ${ }^{28}$ diz que um dos maiores lugares comuns da crítica atual é afirmar que vivemos sob o signo do olhar, na era do simulacro, em que a realidade evapora perante a coletânea de imagens sem referencial. Destaca, então, que, na verdade, esta "onipresença do simulacro também pode ser uma miragem que, ao consagrar o triunfo da pura visibilidade, na verdade arremata uma escravização do olhar à hiper-realidade imagética de caráter eminentemente tátil." Para Otília, a marca da cultura de massa é essa dominância do tátil.

Quando falamos de uma sociedade em que predomina o olhar não estamos, portanto, falando do olhar atento do observador cuidadoso, mas do olhar imediato em que o todo é rapidamente apreendido em uma única visada. A imagem predomina, mas a questão é mais de estímulo visual que de olhar. Este estímulo visual faz com que se passe de uma experiência visual para uma experiência sensorial, chamada tátil por Otília.

A prevalência da imagem como forma de comunicação e da busca por entretenimento chega ao comércio, com lojas cada vez mais semelhantes a parques ou teatros. Mais uma vez, a Disney é pioneira ao associar permanentemente o espetáculo ao espaço de venda em suas Disney Stores, assim descritas 
29. MCMILLAN, Norm. e DOOLITTLE, Sid. It's a Mall World After All. In. Chain Store Age Executive, December, 1989, p.86 In. ROGERS, GAMANS e GRASSI

(1991) p.300

"The store is alive, colorful, exciting. Front windows feature an animated mechanical display

that changes with each store:

Mickey Mouse driving with

his friends in a car, Donald

Duck singing in the rain, surfing scenes, spaceship rides.

Department stores built these

kinds of show windows for

Christmas; Disney does it the year round."

30. BROWN, Paul B. Marketing

as a Theater: Maybe Your Busines. Should Have a Lot More in Common

With Show Biz Than You Think.

INC. September 1988, p.123 In. ROGERS, GAMANS e GRASSI (1991) p.446

31. Big - Quero ser Grande, Gracie Films, 1988. Direção. Penny

Marshall (98 minutos) DVD. por Doolittle e McMillan:

“A loja é viva, colorida, excitante. As vitrines frontais mostram um display animado mecânico que muda em cada filial: Mickey Mouse dirigindo em seu carro com seus amigos, Pato Donald cantando na chuva, cenas de surf, espaçonaves. As lojas de departamento constroem vitrines assim no Natal; a Disney o faz durante o ano todo." 29

Aos poucos cresce a importância do aspecto teatral no visual merchandising. O espaço de venda deveria transformar-se em um espaço de lazer, sendo esta uma das principais questões atuais na promoção de venda. Mais que produtos, as lojas venderiam diversão, conforme afirma Peter L. Harris, da F.A.O. Schwarz ${ }^{30}$, famosa loja de brinquedo em Manhattan, convertida em atração turística principalmente após sua aparição no filme "Quero ser Grande" ${ }^{1}$, de 1988, em que o personagem de Tom Hanks e seu chefe tocam com os pés um gigantesco piano de piso. Harris defende a idéia de que marketing é encenação, e para isso a loja conta com áreas cenográficas variadas, oferecendo atrativos como grandes construções em Lego, maternidade onde se pode escolher a boneca direto do bercinho, e, claro, o famoso piano para ser tocado com os pés que aparece no filme. Entretanto, a loja perdeu muito de seu atrativo para o público turista com inauguração da Toys $R^{\prime} U s$. Além de áreas temáticas e brinquedos em escala gigantesca, a maior loja de brinquedos da cidade conta com uma roda gigante que permeia seus 3 pavimentos, além de oferecer ao visitante a possibilidade de, mediante pagamento, ter sua frase estampada no letreiro luminoso de sua fachada no Times Square.

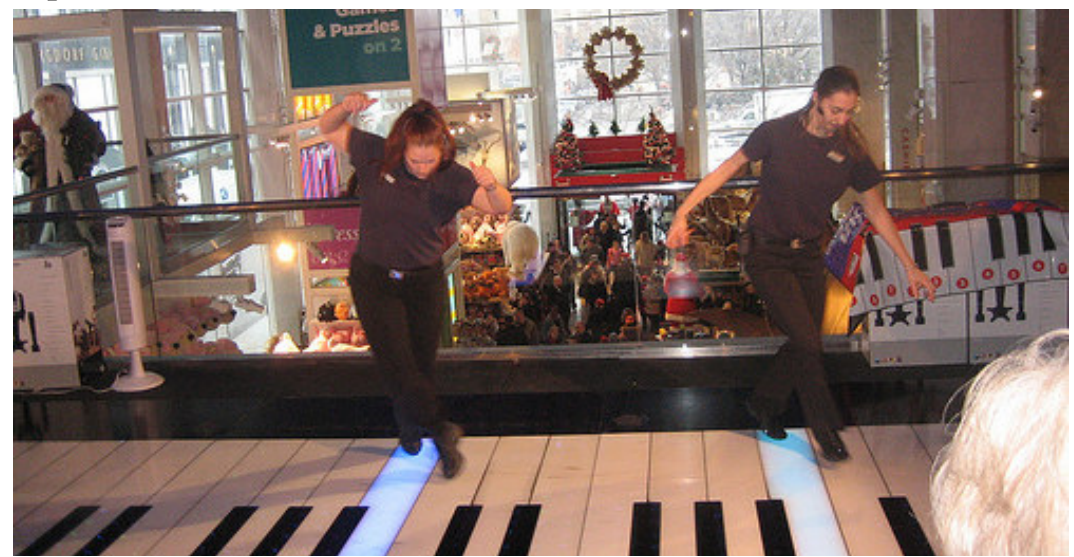

Fig 20. Vendedoras demonstram o piano de pé da FAO Schwarz: 
Assim, vimos simultaneamente a aproximação do público infantil com o universo do consumo, e a construção de uma necessidade do público adulto de consumir experiências e entretenimento. Estes fenômenos associados trazem a demanda do lúdico, possivelmente atendida com o temático.

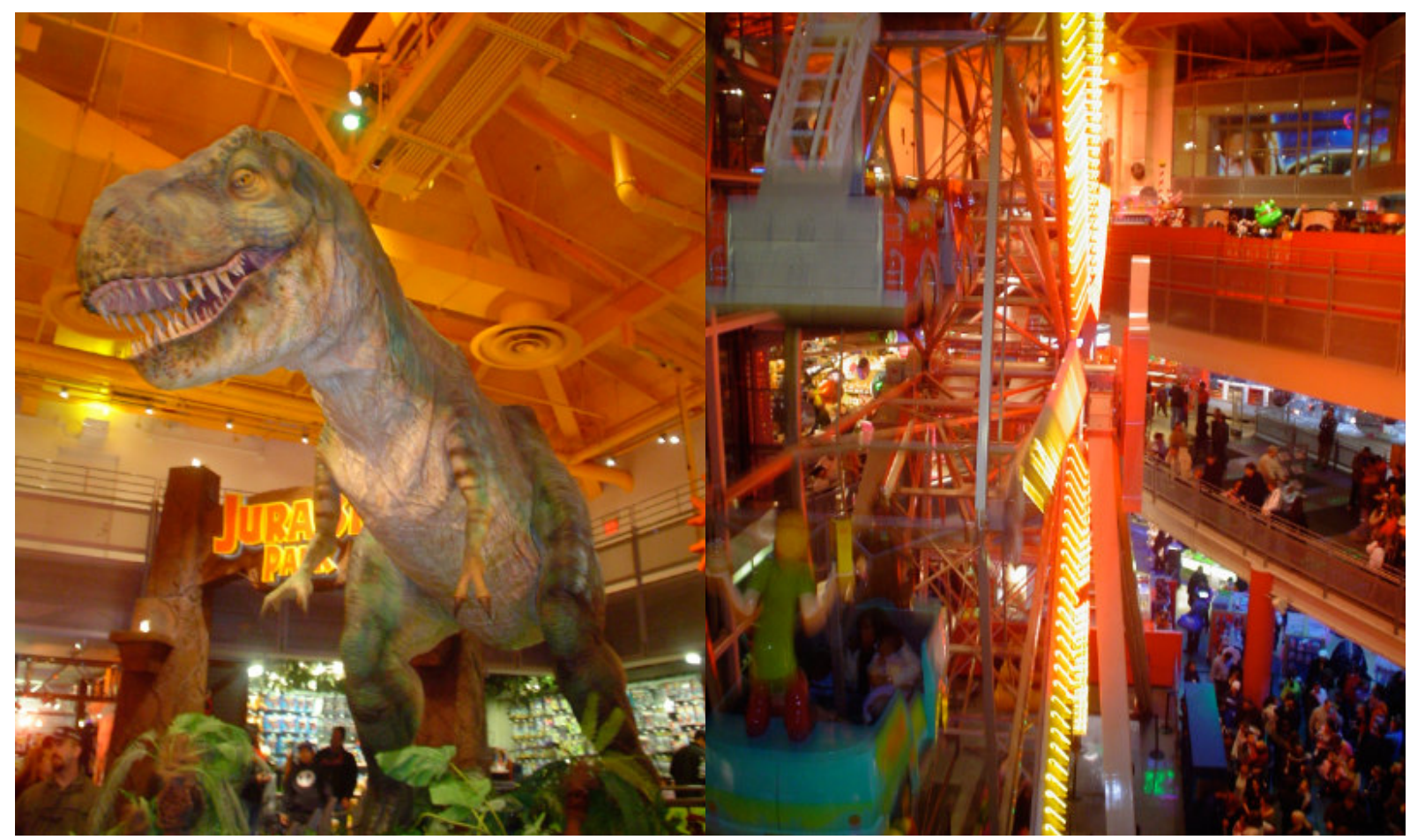

Figs 21 e 22. Toys R'Us, em Nova York.

4.2 Vimos que, dentro de uma cultura progressivamente Marketing de lugar mais visual, o uso do tema com sua transmissão imediata da e turismo mensagem e aspecto lúdico pode atrair freqüentadores, funcionando como instrumento de marketing para estabelecimentos comerciais. Um tema biográfico promove o local em função da fama do indivíduo retratado, da mesma forma em que um bar que possui como tema uma equipe de futebol, por exemplo, atrairá torcedores e admiradores do esporte, que talvez não fossem atraídos sem a temática. Ou seja, o tema pode contribuir para definir o público alvo de determinado estabelecimento. No caso das cidades, a associação com determinado tema pode atrair o visitante que se identifica com o assunto explorado, promovendo o turismo.

Portanto, será necessário revisitar alguns conceitos relacionados ao Turismo. A Organização das Nações Unidas define da seguinte forma o viajante:

"Visitante é toda pessoa que se desloca tem- 
32. CUNHA (1997) p.7.

33. Idem p.9.

34. Ibidem pp.8-9. porariamente para fora de sua residência habitual, quer seja no seu próprio país ou no estrangeiro, por uma razão que não seja a de aí exercer uma profissão remunerada;

Turista é todo o visitante temporário que permanece no local visitado mais de 24 horas; Excursionista é todo o visitante temporário que permanece menos de 24 horas fora da sua residência habitual." 32

Assim, aqui foi feita a opção pelo uso do termo visitante, incluindo tanto o turista quanto o excursionista. É necessário estabelecer, ainda, o conceito de Turismo a ser adotado. A Organização Mundial de Turismo apresentou, em 1991, nova definição, entendendo que:

"O turismo compreende as atividades desenvolvidas por pessoas ao longo de viagens e estadas em locais situados fora do seu enquadramento habitual por um período consecutivo que não ultrapasse um ano, para fins recreativos, de negócios e outros. (...)"33

Cunha apresenta algumas possíveis definições para Turismo, a primeira do ponto de vista dos sociólogos:

“(...) o turista é, antes de tudo, o homem que se desloca para satisfazer sua curiosidade, o desejo de conhecer, para se cultivar e evadir, para repousar ou se divertir num meio diferente do que lhe é habitual. São estes aspectos recreativos, educativos e culturais que levam a considerar o turismo não apenas como um fenômeno econômico mas, antes de tudo, como um fenômeno social (...)"34

Pelo viés da sociologia, seria mais relevante o motivo que leva o viajante a deslocar-se, sendo os dados estatísticos um suporte para análise, e os parâmetros como tempo de estadia e não realização de atividade remunerada relativos. Contudo, como a análise aqui será feita sob a ótica do marketing, adotaremos a definição de Cunha, que diz:

“(...) do ponto de vista econômico, considere-

mos que o turismo abrange todas as deslocações de pessoas, quaisquer que sejam as suas motivações, que obriguem ao pagamento de prestações e serviços durante a sua deslocação e permanência temporária fora da sua residência habitual superior ao rendimento que, 
35. Ibidem pp.9-10.

eventualmente, aufiram no locais visitados. $\mathrm{O}$

turismo é, assim, uma transferência espacial de poder de compra pela deslocação de pessoas $(\ldots)^{\prime \prime 35}$

Esta definição é adotada porque torna-se difícil não apenas identificar os viajantes que exercerão atividade remunerada, mas também estabelecer critérios que os diferenciem daqueles motivados por alguma espécie de trabalho. Ultimamente, têm se tornado populares programas de intercâmbio para estudantes que trabalham em outro país durante seu período de férias. Programas como o "Work Experience"36, que leva jovens universitários para exercer atividades remuneradas no Estados Unidos, são vendidos como atividade cultural, como uma chance de vivenciar outra cultura, não uma oportunidade de trabalho. Ainda que estes estudantes recebam pela atividade, o programa é pago e a motivação da maioria é o turismo. Ainda que fique complicado identificar estatisticamente quantos têm retorno financeiro com a experiência e quantos fazem do salário recebido um auxílio para a viagem, consideramos que faz turismo aquele que gasta mais do que recebe, em contraposição àquele que viaja para obter lucro.

Sobre a história do Turismo, Cunha identifica três momentos. O primeiro, chamado "Idade Clássica" abrange o período desde as primeiras civilizações à metade inicial do século XVII:

"A Idade Clássica do turismo, que se prolonga até ao século XVIII, caracteriza-se pelo facto das viagens serem individuais e se realizarem, predominantemente, por necessidades fundamentais como o comércio, as peregrinações religiosas, a saúde ou por razões políticas e de estudo. Neste período, os centros que, na perspectiva actual, se podiam considerar como turísticos eram as estâncias termais. que atraíam principalmente as pessoas que procuravam remédio para os seus males e os centros

37. CUNHA (1997) p.64. religiosos que atraíam os peregrinos." ${ }^{37}$

É possível perceber que o caráter de espetáculo associado ao turismo já se encontra presente. Embora o lazer comercializável tenha sido introduzido em lojas e magazines no século XIX, a função social sempre esteve presente em espaços de comércio, atraindo visitantes para compras ou apenas 
38. WILFRED BURNS, British

Shopping Centers: New Trends in

Lay-out and Distribution, Londres:

Leonard Hill Books Limited, 1959.

In VARGAS (2001) p.96.

39. A ágora foi o espaço criado para a realização do comércio quando a população ultrapassou os limites das muralhas e o espaço ao pé da acrópole tornou-se pequeno. Trata-se de uma praça que abriga o comércio varejista e, conseqüentemente, o centro de atividades sociais da cidade. In VARGAS (2001) p.116. passeios. Mesmo os mercados e feiras da antigüidade não se limitaram ao fornecimento de mercadorias. Os primeiros mercados já funcionavam como ponto de encontro, oferecendo atrações como brigas de galo, por exemplo. ${ }^{38} \mathrm{Na}$ ágora gre$\mathrm{ga}^{39}$ podiam ser verificados elementos que assumiam a função de envolver o consumidor. Desde a fonte de água, elemento de atração pela necessidade de abastecimento, passando pelas cores e movimento intenso do espaço e pelo barulho da propaganda feita oralmente, diversos elementos contribuíam para que o freqüentador se sentisse parte integrante do conjunto. Portanto, os espaços de comércio sempre possuíram um papel como atividade social, não apenas econômica. Da mesma forma as grandes atrações turísticas vendem uma experiência, cada vez mais explorada em seu caráter espetacular, o que já acontecia de certa forma com as Maravilhas do Mundo Antigo.

No período seguinte, chamado "Idade Moderna", são popularizadas as viagens de lazer, com o surgimento, ainda no século XVIII, do Grand Tour, viagem pela Europa realizada por estudantes, diplomatas e membros de famílias abastadas de um modo geral. Já no século XIX, a Revolução Industrial permite o desenvolvimento dos transportes, especialmente trens, favorecendo o deslocamento. O início da publicação de jornais permite uma divulgação mais extensa dos centros de atração turística, promovendo interesse em tradições e particularidades de outras culturas. A propaganda adquire grande importância a partir de então, atingindo atualmente o posto de principal responsável pela valorização de determinado local. Além disso, a redução da jornada de trabalho permite o descanso semanal, estabelecendo o conceito de lazer. Cunha resume este período como aquele em que:

\footnotetext{
“(...) o turismo inicia a sua expansão mundial, caracterizando-se pela procura de diversão e descanso e pelas viagens culturais. Inicia-se o desenvolvimento dos transportes modernos com o lançamento de redes internacionais de caminho de ferro, de barco, a criação das primeiras companhias aéreas e o nascimento do automóvel e do auto-carro." ${ }^{\not 40}$
}

Finalmente, o período atual, chamado "Idade Con- 
temporânea", com início no século XX, caracteriza-se pela consolidação do turismo enquanto atividade econômica significativa. Até o início da Segunda Guerra Mundial, houve um contínuo desenvolvimento de transportes aliado ao estabelecimento dos direitos do trabalhador, incluindo férias remuneradas, além do desenvolvimento da publicidade e criação de órgãos nacionais e internacionais voltados à promoção do turismo, permitindo sua inegável expansão. Entretanto a crise originada com a Guerra faz com que o turismo praticamente desapareça.

O fim da Guerra faz com que, segundo Cunha, o período entre 1945 e 1973, assista um retorno do turismo, de acordo com as condições explicitadas:

"Os efeitos produzidos a nível do turismo

(...) operaram-se por via, em primeiro lugar, do tempo livre, decorrente da diminuição do tempo de trabalho semanal e da generalização das férias pagas nos países desenvolvidos, em segundo lugar, por via do rendimento, na medida em que aumentou o rendimento considerado discricionário e se adoptaram medidas sociais (pensões de reforma, pagamento das despesas com doença, subsídios à família) que facilitaram a compra de viagens e, em terceiro lugar, por via das motivações, já que a necessidade de diversificação e diferenciação se manifestou com cada vez mais intensidade e as pessoas passaram a ter necessidade de compensar os desequilíbrios psicológicos ligados à vida profissional pela evasão ao meio." ${ }^{\text {41 }}$

Entre 1973 e 1990, a emergência da questão ecológica leva o homem a perceber que coloca em perigo o ambiente em que vive. Surge como nova opção o chamado turismo ecológico. No Brasil, localidades com o Pantanal Matogrossense e a Floresta Amazônica são explorados turisticamente, atraindo visitantes estrangeiros que desejam conhecer ecossistemas distintos do seu e matas preservadas. Hoje, o grande desafio talvez seja promover o turismo sustentável do ponto de vista ecológico, permitindo e incentivando o deslocamento de pessoas a áreas preservadas, sem promover sua destruição.

É também o período em que se acentuam as diferenças econômicas entre países desenvolvidos e em desenvolvimento, 
bem como entre as classes sociais. Esta distância não reduz o turismo, que já é considerado bem essencial, porém leva a uma procura por destinos mais próximos e econômicos. Surgem as fórmulas de alojamentos de baixo custo, no Brasil caracterizadas pelo clubes de férias.

A economia se restabelece no final da década de 80 , porém reencontra a recessão a partir de 1992. Se não chega a abalar o turismo, a recessão faz com que mantenha taxas de crescimento menos elevadas. Recentemente, a fórmula de baixo custo atingiu novos níveis, com a entrada no mercado de hotéis e companhias aéreas Low Cost que otimizam a ocupação, enxugando gastos e baixando agressivamente o custo para o consumidor final. Algumas como a irlandesa Ryan Air, pioneira no setor, chegam a anunciar passagens partindo de diversos pontos e para diversos destinos na Europa ao custo de zero Euro. O comprador paga a taxa de embarque e qualquer serviço adicional que deseje - prioridade no embarque, lanche, transporte de malas, etc.

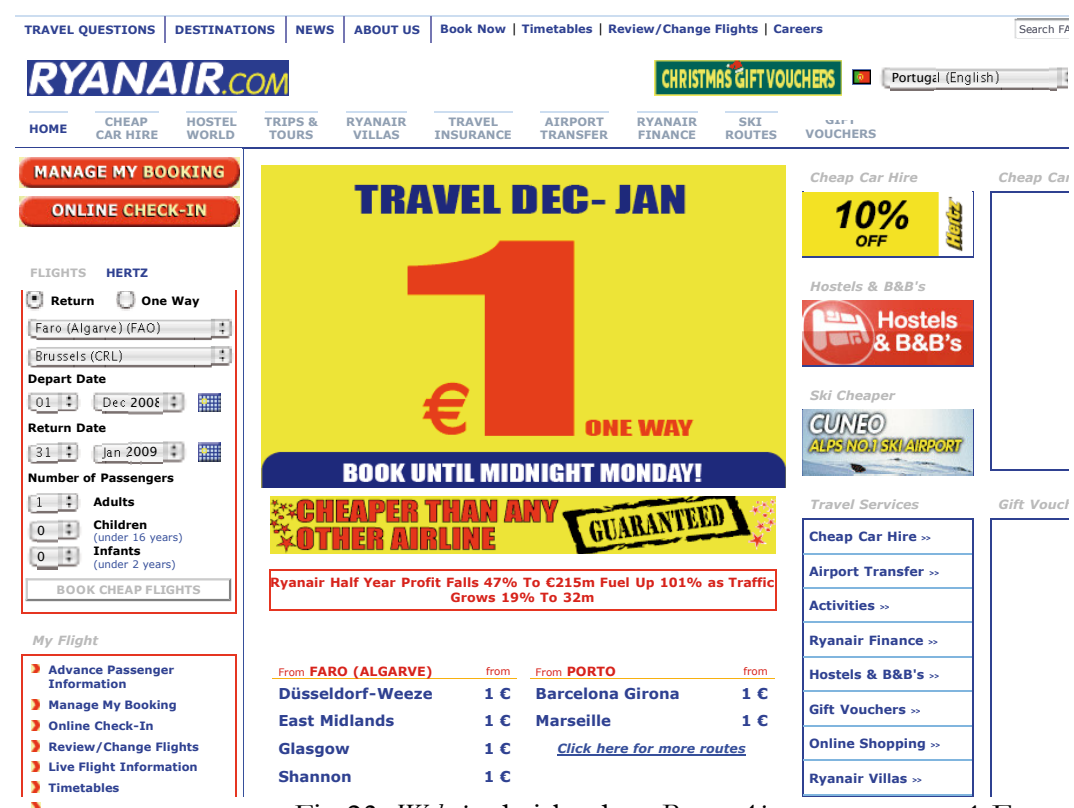

Fig 23. Website da irlandesa Ryan Air - passagens a 1 Euro.

Dentre as características do turismo contemporâneo, Cunha destaca a Valorização, segundo a qual "o turista mais preocupado com os aspectos imateriais do turismo passou a encarar as viagens como forma de valorização e afirmação pessoal." O tema pode ser utilizado como símbolo de status para estabelecimentos como os já citados hotéis-cassino. De um modo geral podemos observar a ocorrência de temas gran- 
diosos como a Roma antiga (Ceasar's), castelos medievais (Excalibur) ou pirâmides egípcias (Luxor). Entretanto, temas distintos são aplicados, criando diversas identidades para espaços que objetivam públicos variados, ou seja, valorizando o local aos olhos de seu público alvo.

Portanto, o tema adiciona ao estabelecimento as características que carrega consigo, podendo fazer com que este aparente luxo, despojamento, inovação, modernidade ou qualquer outra idéia associada à temática escolhida. A associação da imagem de pessoas consagradas a produtos é, há tempos, uma conhecida estratégia de marketing. O status e reconhecimento do ídolo fica agregado ao produto em questão. Hoje, a utilização da reputação de personalidades e marcas de um modo geral extrapola o nível do produto e atinge o espaço de venda. Porém, não se pode esquecer que no comércio de entretenimento o próprio espaço já é um produto.

Esta inclusão de temas no espaço construído torna-se eficiente para atrair não só o público local, mas, em primeiro lugar, o visitante. Para ele, o tema pode ser uma diferenciação entre um espaço corriqueiro como um bar comum e um bar que, de acordo com o tema apresentado, adquire caráter único. Assim, também cidades buscam no tema a diferenciação que potencializa ou constrói um potencial turístico a ser explorado.

42. CASTROGIOVANNI e GASTAL (1999) p.5.
Para Castrogiovanni e Gastal ${ }^{42}$, o turismo contemporâneo surge com a Revolução Industrial e passa a ser de massa com a Segunda Guerra Mundial. O turismo de massa coloca a produção turística como um dos negócios mais rentáveis e de maior crescimento sustentável das últimas décadas. Afirmam que a distância entre tempo livre e descanso será cada vez menos clara, com o turismo ocupando progressivamente o tempo de ócio e ganhando destaque. Neste cenário, o espaço urbano ofereceria ofertas de lazer como nenhum outro, conjugando produtos culturais diversos, cultura, lazer e oferta de negócios.

No Brasil, é bastante comum a estratégia de divulgar a cidade como centro de referência em alguma coisa - flores, bordados, artesanato, comidas, animais. Qualquer produto típico pode ser explorado na divulgação do local para promovê- 
43. www.feiradobrodadodeibitinga. com.br

lo para o turismo. O tema costuma ser associado a festas e eventos que o exaltem, podendo ser explorado na arquitetura ou não. Muitas vezes aparece em websites, folders, banners espalhados pela cidade, mobiliário urbano e outras formas de propaganda, sem necessariamente contar com edificações que remetam à temática adotada. De qualquer forma, ao menos na área mais visitada pelos turistas, o espaço urbano aproxima-se de um Espaço Temático literal, adotando o máximo possível de referências que lembrem o tema narrado. Além disso, como nos Espaços Temáticos auto-legitimados, aqui as próprias cidades se colocam como "a cidade de alguma coisa". Assim, a exploração de um tema como estratégia de divulgação de cidades para o turismo busca consolidar ou construir identidades, definindo o público alvo do local e contribuindo para atrair este público.

Há inúmeros exemplos a serem citados, dentre eles Ibitinga, em Minas Gerais ${ }^{43}$ - "a capital nacional do bordado" que enfoca o turismo comercial, visando atrair revendedores para os produtos bordados tradicionalmente produzidos no local, mas associa a feira que acontece anualmente a uma série de shows, eventos e até parque de diversões que atraem público mais amplo. Em Paty do Alferes, Rio de Janeiro, a Festa do Tomate, realizada anualmente, atrai cerca de 40 mil visitantes por dia. ${ }^{44}$ Além de eventos associados à produção agrícola, como o "Concurso de qualidade do tomate", a Festa inclui shows com músicos populares. Ou seja, nestes casos a vocação do local funciona como inspiração inicial, justificando o evento. O produto local é explorado em logomarcas e divulgação, mas não chega à arquitetura e mobiliário urbano. Já em Holambra, auto proclamada a cidade das flores, há placas de sinalização temáticas em forma de tulipa ou moinho e arquite-

Fig 24. Logo da prefeitura de Paty do Alferes. tura que recria características européias, mais especificamente holandesas. Além disso, buscando remeter à colonização holandesa, está construindo o maior moinho da América Latina, assim descrito no website da prefeitura da cidade:

"O equipamento, que terá 38 metros de altura e será uma cópia fiel dos tradicionais moinhos holandeses já está sendo construído pela prefeitura de Holambra(...) O projeto do moinho foi elaborado pelo arquiteto holandês Jan 
45. www.holambra.sp.gov.br

46. GOLD e WARD (1994) p.2. “(...) the concious use of publicity and marketing to communicate selective images of specific geographical localities or areas to a target audience."

47. Idem pp.1-19.
Heidra, que também está supervisionando a construção do equipamento, que funcionará pela força do vento e moerá grãos, exatamente como acontece na Holanda. O moinho terá um mirante que permitirá a seus visitantes uma visão privilegiada da Cidade das Flores e de municípios vizinhos. (...) Depois de pronto, o moinho será a maior obra arquitetônica de toda a região e ficará aberto à visitação pública como mais uma atração turística da Cidade das Flores." 45

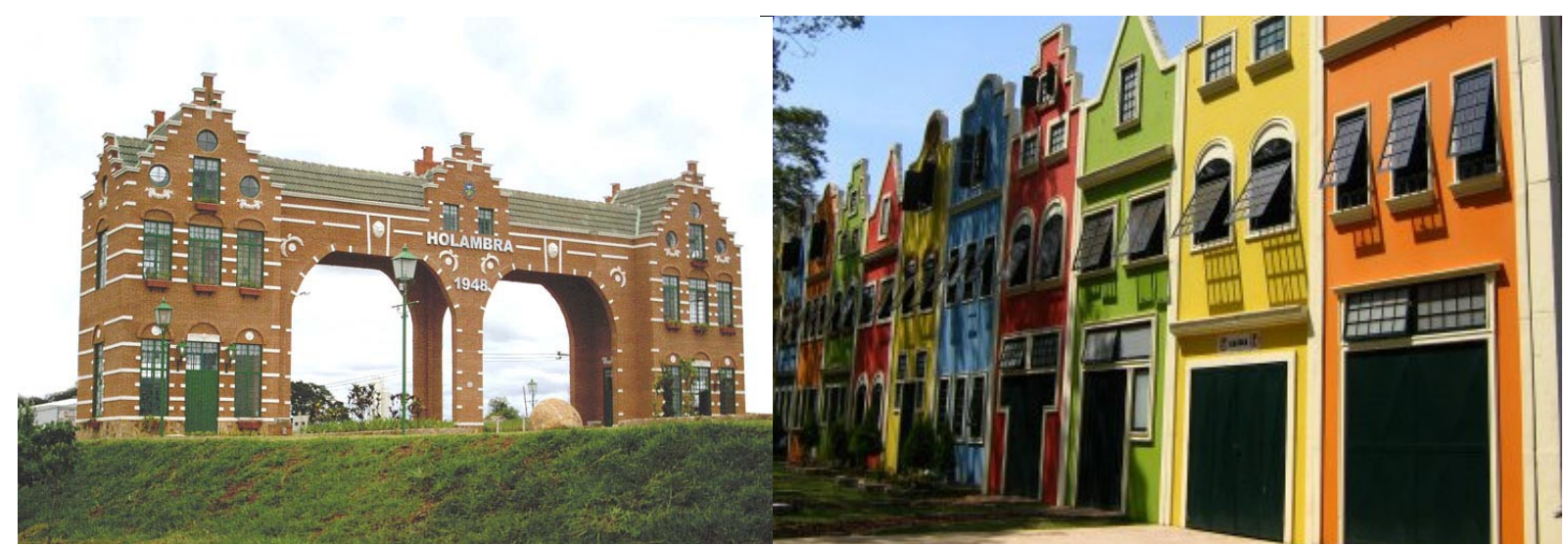

Figs 25 e 26. Holambra - portal de entrada e rua.

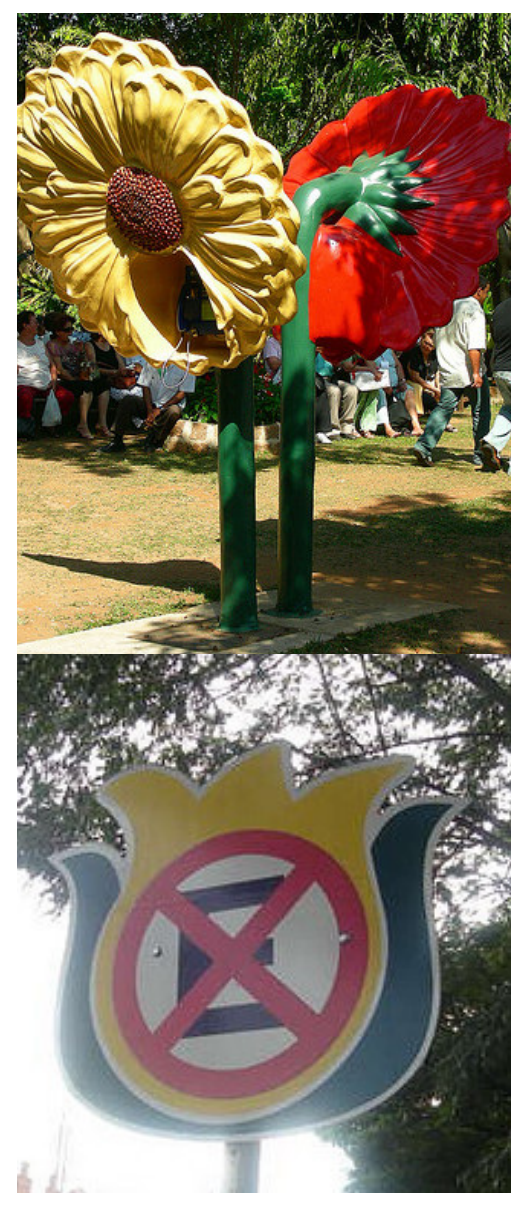

Figs 27 e 28. Holambra - telefones públicos e sinalização de trânsito.
Buscamos, então, a origem do uso de marketing como divulgação de locais. A promoção de lugares - place promotion - pode ser definida como “(...) o uso consciente de publicidade e marketing para comunicar uma imagem selecionada de um lugar específico ou áreas, para um público alvo." ${ }^{46}$ Remonta ao período de exploração colonial em que os jornais apresentavam aos europeus anúncios incentivando os "aventureiros" a explorar o mundo desconhecido das colônias na África, América ou Oceania. Mais tarde foi usada para promover cidades litorâneas, sempre associadas à areia branca e mar transparente, cidades históricas associadas a seu tempo de existência e conservação, subúrbios associados à vida pacata e segura e, finalmente, complexos de lazer, relacionados à experiência familiar, com o pioneirismo da Disneyland. Estes clichês são evocados até hoje, em campanhas mais recentes como a "I Love New York.", de 1977.47 Entretanto, neste momento ainda se trata de uma política pública de promoção, visando o orgulho, bem estar e benefício social dos moradores da cidade. Gold e Ward ressaltam a diferença, tratando de place promotion e place marketing separadamente. Porém, mostram que, hoje, as 


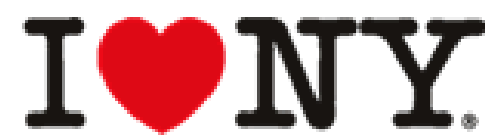

Fig 29. Marca da cidade de Nova York.

48. Ibidem pp.1-17.

49. ASHWORTH, Gregory J. e VOOGD, Henk. Marketing and place promotion. In. GOLD e WARD (1994) pp.39-52.

50. WARD, Stephen. Time and place: key themes in place promotion in the US A, Canada and Britain since 1870. In. In. GOLD e WARD (1994) pp.53-74.

técnicas de marketing permitem suporte à promoção de lugar e vêm sendo usadas, originando um paradoxo, já que o benefício de uma cidade ao ser promovida poderia se dar às custas de suas vizinhas, em uma espécie de competição pelo público consumidor. Tal situação, comum nos Estados Unidos, era ainda novidade na Grã-Bretanha.

Sobre o Place Marketing, ressaltam que a transformação da cidade em produto é bastante complexa, já que não se sabe exatamente como é este produto, tampouco em que circunstâncias se dará o consumo, excetuando os lugares concebidos como produtos - Disneyland e afins. A solução encontrada tem sido divulgar o local mais através de imagens e associação de sentimentos, menos através de dados e informações. Essa divulgação fragmentária permite associações distintas para consumidores diversos. ${ }^{48}$

Como vimos, a promoção de lugares não é novidade, poderíamos acrescentar que tampouco é a competição por mercado entre cidades. Para Ashworth e Voogd, a novidade reside na aplicação consciente de técnicas de marketing por agências de planejamento público, chegando a adotá-las como filosofia de administração pública. ${ }^{49}$

Podemos exemplificar a transição analisando a promoção de lugar nas cidades sulistas norte-americanas. Na segunda metade do século XX, a promoção nos EUA visava reerguer o sul devastado pela guerra civil. Já na década de 20, as cidades sulistas agregavam à promoção políticas reformistas, por exemplo, nos campos da educação ou saúde pública. A partir de 1945, após a guerra, o sul procurava vender-se por seu desenvolvimento industrial. Já na década de 70, a promoção se volta para o comércio e serviços e, finalmente, vemos com clareza a mudança na promoção de cidades em 1990, com o triunfo de Atlanta na disputa para sediar os Jogos Olímpicos de $96 . .^{50}$

Embora não haja ainda uma teoria conclusiva relacionando este efeito, é fato que a mídia exerce grande influência sobre o turismo. Eventos como os Jogos Olímpicos, com transmissão em massa, atraem um grande público, ao passo que a divulgação de tragédias, como guerras ou ataques ter51. NIELSEN (2002) roristas, afasta o turista. ${ }^{51}$ Se há uma influência através de 
52. Casablanca, Warner Bros. / Metro-Goldwyn-Mayer, 1942 Direção Michael Curtis (103 min)

DVD

53. www.salzburg.info

54. A Noviça Rebelde - The Sound of Music. 20th Century Fox,1965.

Direção Robert Wise (172 min)

DVD notícias e transmissão de eventos, certamente haverá sobre o viajante, influência da imagem do local divulgada na mídia. Como vimos com Postman, a imagem é muito marcante e nossa cultura de visualidade preza por seu reconhecimento. Mais do que saber que há uma guerra, fixamos a imagem de destruição apresentada no noticiário. Da mesma forma, fixamos monumentos divulgados como pontos turísticos ou locais que foram cenários para filmes. E o marketing de lugar com foco turístico explora esse reconhecimento. O Marrocos deve grande parte de seu público visitante à divulgação através do filme "Casablanca" 52 , ainda que nenhuma cena do filme tenha sido gravada no país. O mesmo pode se dizer de Salzburg, na Áustria. Ainda que a população prefira que sua cidade seja reconhecida como a cidade natal de Mozart, ou por ser declarada Patrimônio Cultural e Natural da UNESCO ${ }^{53}$, muitos visitantes a procuram por ter sido o cenário do musical "A Noviça Rebelde" 54 . Há, inclusive, tours especializados em levar aos sets de filmagem e shows inspirados no filme.

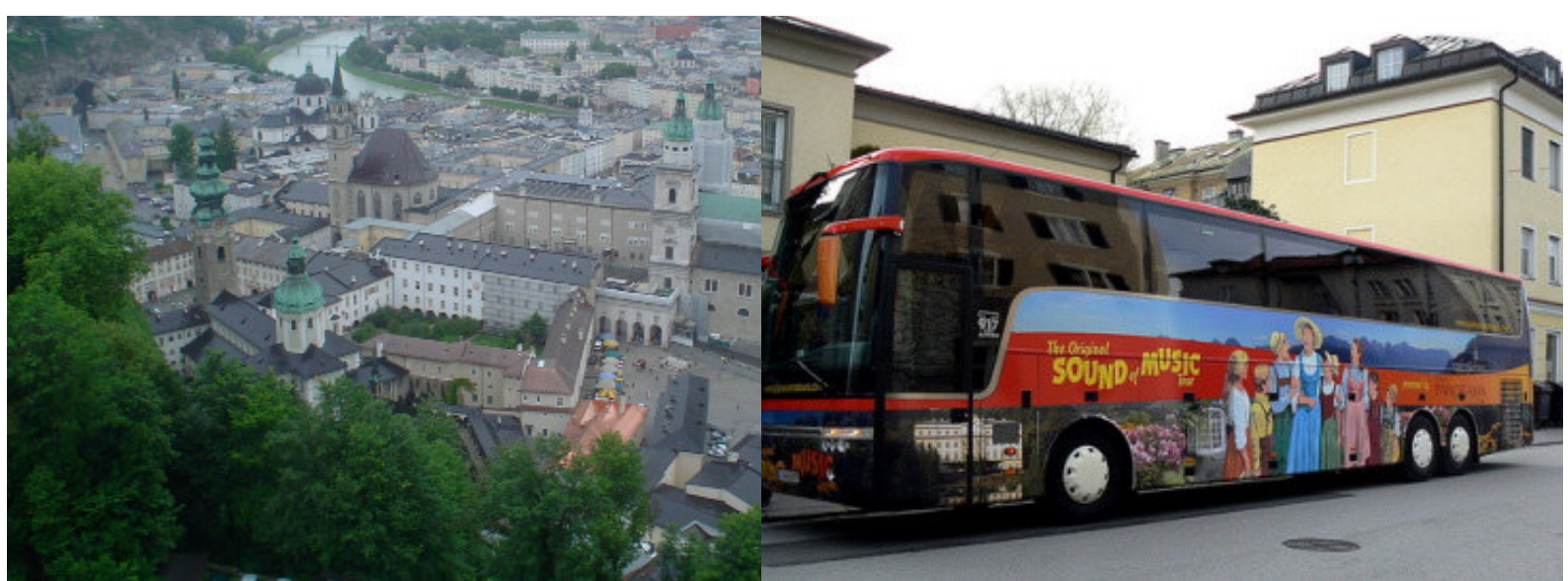

Figs 30 e 31. Salzburg - vista do centro histórico e ônibus especializado em levar turistas às locações de "A noviça rebelde".

Vimos que está consolidado o uso do marketing de lugar com enfoque turístico, entretanto vem sendo levantado seu uso objetivando desenvolvimento comercial e social, através da exploração da imagem de países como marcas. Ao 55. ANHOLT (2005) contrário do que se poderia imaginar, Simon Anholt ${ }^{55}$ defende, inclusive, o uso de marketing como instrumento para favorecer o comércio em países em desenvolvimento.

Países, cidades ou regiões são percebidos, sob muitos aspectos como marca, já que sua imagem é associada, tanto pela população quanto pelo público externo, a certas quali- 
56. Idem pp.106-107.
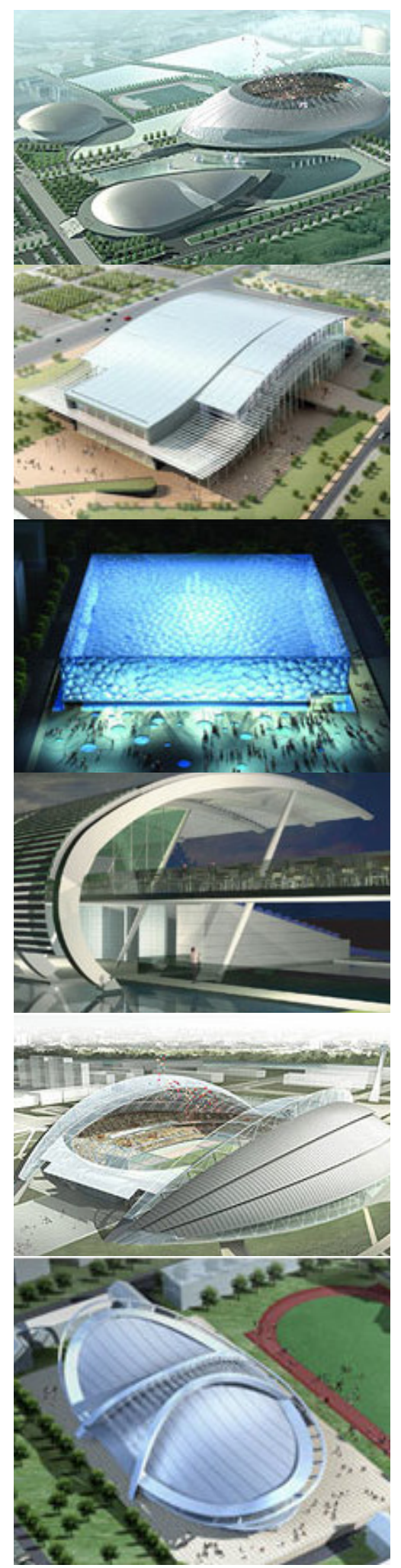

Figs 32 a 37. Instalações construídas ou reformadas para os Jogos Olímpicos de 2008, em Pequim dades e características. Anholt defende que a valorização da marca que cada país representa pode contribuir para seu desenvolvimento econômico sob dois aspectos. A valorização de marcas nacionais no mercado internacional poderia trazer maior confiabilidade para o país que seria associado à marca, evidentemente, no caso de o consumidor conhecer sua origem. O consumidor poderia, pouco a pouco, mudar a imagem que tem sobre o país que produz aquela mercadoria valorizada, ao mesmo tempo em que o sucesso de um produto nacional no mercado exterior pode gerar um certo orgulho na população local. Entretanto, interessa aqui especialmente o segundo aspecto levantado por Anholt, propondo a valorização do próprio país enquanto marca. ${ }^{56}$

Anholt cita o exemplo da Escócia, que promoveu a construção de uma marca, reinventando a imagem do país, a partir da literatura de Walter Scott. A imagem que fazemos hoje do país - tartans, kilts, gaitas de fole, etc - decorre de uma releitura em parte cultural, em parte fantasiosa, feita por Scott. Como a imagem nos é agradável, permaneceu por anos e é explorada por "The Scottish Tourist Board". Da mesma forma, o Japão mudou radicalmente sua visão enquanto marca ao ser hoje associado à modernidade e tecnologia, quando até a década de 60 os produtos japoneses eram vistos como algo de segunda categoria, compráveis apenas por serem mais baratos. Algo semelhante vem acontecendo com a Coréia do Sul, que busca associar sua imagem à tecnologia através de marcas bem sucedidas como Samsung, Kia e LG. Ao realizar a Copa do Mundo de 2002 junto com o Japão, o país pretendeu equiparar as duas marcas.

O mesmo parece estar tentando fazer a China, cujos produtos encontram-se hoje em situação próxima aos japoneses na década de 50 ou 60. Ao realizar os Jogos Olímpicos, o país não poupou esforços para ter seu nome associado à modernidade, tecnologia, organização e perfeição. Chegou a virar piada a forma como o governo adotou cartazes e cursos que ensinassem à população como torcer corretamente, em um claro esforço para promover a valorização da marca China.

Curiosamente, o Brasil é o exemplo de exploração desfavorável de marca citado por Anholt. As características co- 


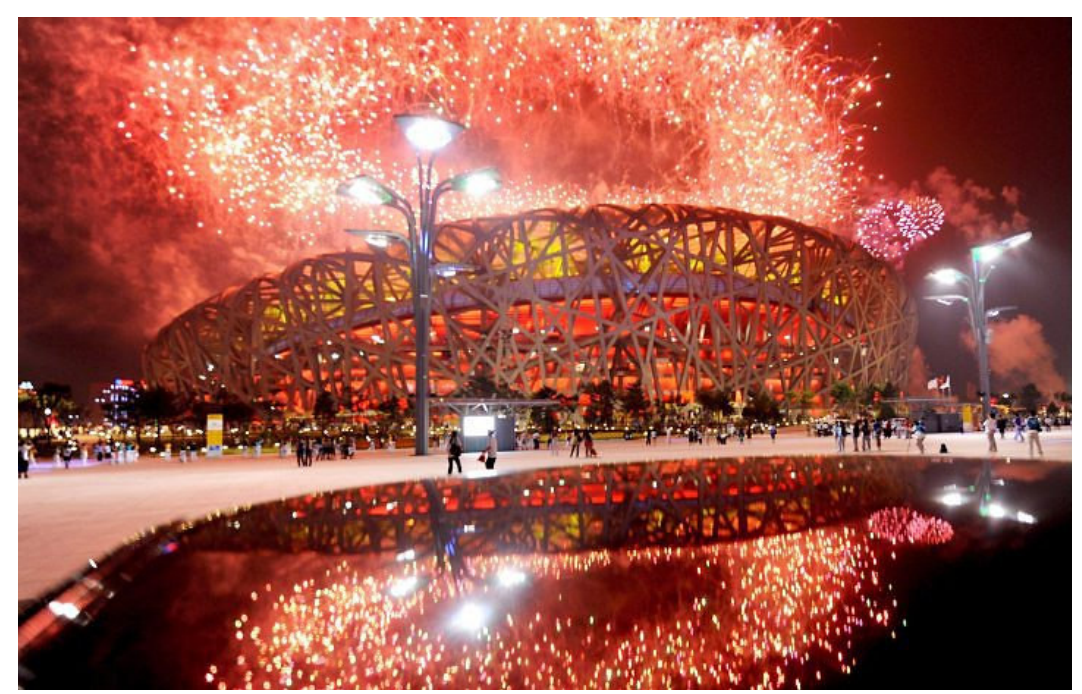

Fig 38. Estádio olímpico de Pequim, projeto de Herzog e de Meuron. mumente associadas à marca "Brazill" - carnaval, festa, florestas tropicais, praias, esporte, etc - poderiam estar associadas a qualquer produto jovem e são ambicionadas por marcas poderosas ao redor do mundo, entretanto o país não possui grandes marcas internacionais. Ainda que muitas destas características possam parecer ofensivas ao brasileiro e existam, inegavelmente, sérios problemas no país, o autor diz que a imagem que ostenta seria um excelente princípio para construir marcas sólidas e bem aceitas. Para comprovar este potencial, cita a Reef Brazil, bem sucedida marca de moda praia americana fundada, em 1984, por dois argentinos. Após a consolidação,

57. www.reef.com 58. ANHOLT (2005) pp.112-114. a marca associada à imagem brasileira, apresenta-se agora apenas como Reef $f^{57}$, porém sua própria existência revela que há mercado para a marca Brazil..$^{58}$ Assim como a marca americana se passa por brasileira, outras, ainda que não tão diretamente, usam a sonoridade de seus nomes ou mesmo utilizam línguas estrangeiras, para evocar localidades.

Poderíamos pensar em valorização da marca para promover o turismo e, de fato, é o que ocorre em pequenas estâncias turísticas, cujo produto principal é o turismo. Entretanto, Anholt demonstra que a valorização do país enquanto marca pode contribuir para promover produtos, afinal associamos produtos italianos a algo sensual e cheio de estilo - Ferrari, Gucci - ingleses a uma certa tradição e esnobismo - Burberry, Rolls Royce - ou americanos a juventude - Coca-cola, MTV-e esportes - Nike, Reebok, NBA.

A exemplo dos já citados "comerciais de longa dura- 


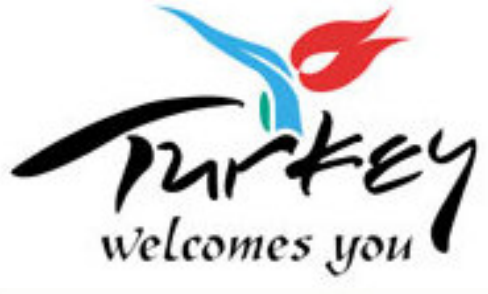

THAILAND

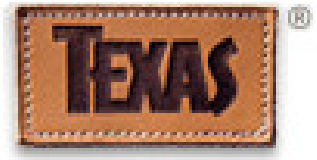

Ats like a whole whex counby.

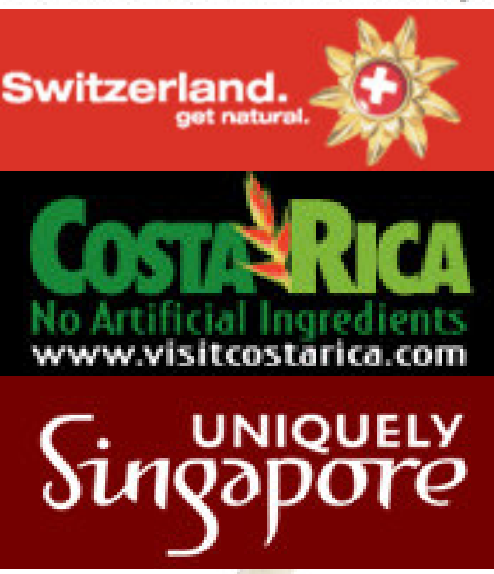

IT'S GOT

TO BE

AUSTRIA.

Figs 39 a 45. Logos e slogans atuais para Turquia, Tailândia, Texas, Suíça, Costa Rica, Singapura e Áustria.

59. Idem pp.108-111.

60. LANSKY, Dou. Last Trout in Venice, Travelers' Tales Inc. 2001. In ANHOLT (2005) pp. 127-128.

61. www.visitcostarica.com ção", o autor mostra que a marca 'USA' tem em Hollywood uma poderosa agência de publicidade. Seus filmes vêm contribuindo para construir e vender o país ao mundo. Durante anos a marca 'USA' tem sido a mais valorizada, aquela cujas características são ambicionadas pela grande maioria dos consumidores e dos países que sonham construir sua marca nos moldes da americana. ${ }^{59}$ Recentemente, a marca tem perdido valor, provavelmente por já não apresentar o desconhecido ou representar aspirações associadas ao "american way of life", hoje acessível ao público consumidor mundial, mas também por incluir cada vez mais aspectos negativos em sua imagem.

Assim, é preciso diferenciar promoção turística de promoção de marca, pois inclusive o aspecto promovido para o turista pode não se mostrar interessante na promoção de negócios - um turista teria interesse em permanecer em um suposto "país de praias desertas", ao passo que uma grande empresa provavelmente não estaria interessada em instalar fábricas no local. Visando o turismo, muitos locais chegam a criar slogans, entretanto parece que tornam-se todos muito parecidos, contribuindo pouco para a diferenciação desejada. Dentre os incontáveis exemplos, temos: Singapura- So easy to Enjoy, Ilhas Mauricio - Fascination, Polônia - Natural Choice, Suíça - Your Holliday, Áustria - Holliday Break Away, Turquia - Welcome to Friends, Carolina do Norte - A Better Place to Be, Islândia e Tailândia (possuem o mesmo) - Amazing, Fort Worth - Capturing the world's attention, Texas - A bole other country, Colômbia - The continent country ${ }^{60}$ e Costa Rica - Pura Vida e No artificial ingredients. ${ }^{61}$

Segundo Middleton, as Administrações Nacionais de Turismo escolhem as mensagens e símbolos responsáveis pela marca que o país divulgará como forma de diferenciação, rótulos como "I love New York" ou "The World Next Door", canadense. Middleton lista características determinantes para o sucesso prático desta "marca":

"Ser baseados em valores e atributos de produtos genuínos que possam ser fornecidos e que os visitantes reconheçam como autênticos, não falsos.

Ser facilmente compreendidos pelos consumidores no local da compra. 
62. MIDDLETON (2002)

pp.367-368.
Envolver pelo menos os principais jogadores do setor comercial.

Ser incorporados nos esforços promocionais das regiões e resorts de um país.

Ser mantidos por vários anos se estiverem superando a inércia e as barreiras da comunicação

Ser explorados sistematicamente em uma gama de técnicas de promoção de vendas e serviços ao cliente projetadas para atingir visitantes na chegada aos destinos, bem como visitantes potenciais nos países de origem." ${ }^{62}$

Não é fácil remodelar a marca de um país, trata-se de um conceito construído ao longo de muito tempo e às custas de muitas ocorrências históricas. Para Anholt, a visão da população local sobre seu lugar funciona melhor que promoções turísticas convencionais. Fatos como a vitória em campeonatos esportivos mundiais também podem ser capitalizados, mas, muitas vezes, um acontecimento isolado torna-se mais efetivo. Segundo o exemplo citado, a compra de uma casa em Londres pela cantora Madona fez mais pela imagem da cidade como um local contemporâneo em alta que qualquer publicidade. O acontecimento ganhou as páginas dos jornais do 63. ANHOLT (2005) p.120. mundo, em uma publicidade efetiva e gratuita para Londres. ${ }^{63}$ Assim, uma publicidade 'por trás dos panos', orquestrando acontecimentos como este, poderia funcionar mais que um plano promocional, do qual o público tende a desconfiar. É bastante comum que famosos ou pseudo-famosos sejam contratados para marcar presença em eventos, de forma a associar sua imagem ao produto promovido, o que poderia de alguma forma ser transposto para o marketing de lugar.

A representação cultural neste processo de construção de marca é fundamental para humanizar o local, trazendo para sua imagem características mais realistas e fugindo de clichês. Ao envolver este aspecto cultural, poderíamos tanto pensar positivamente - "tudo bem, vamos promover a cultura, resgatar as raízes!" - quanto negativamente - "transformar em marketing a cultura local, que sacrilégio!". Anholt afirma que, dependendo os países do mercado global, e estando a saúde econômico-financeira dos países desenvolvidos completamente ligada à sua capacidade de exportar marcas, não há outra 
64.Idem p.163. saída além do fortalecimento da marca local. Entretanto, cabe “(...) marketing is not the convenient scapegoat for the evils of consumerism or global capitalism which many would have it: the truth, as always, is more complex and contradictory than this. (...) marketing is not about adding worthless gloss to worthless products, or persuading dumb consumers to waste money on rubbish they neither need nor want, nor is it a charlatan's trick for overcharging people for ordinary products. It is a way of squeezing more value out of a marketplace; a way of stimulating trade and commerce; and in the right hands, an immensely powerful instrument for widespread social and cultural change." deixar claro que é valorizado o intercâmbio cultural, não a colonização cultural. Para este intercâmbio, é necessário que os países em desenvolvimento valorizem-se enquanto marcas, afinal, conforme afirma Anholt:
“(...) o marketing não é um bode espiatório coveniente para os males do cosumismo ou do capitalismo global, como muitos pensa- riam: a verdade, como sempre, é mais com- plexa e contraditória que isso. (...) marketing não é adicionar brilho a produtos sem valor, ou convencer consumidores bobos a gastar dinheiro em porcarias que não querem e nem necessitam, tampouco é um truque de charla- tões para encarecer produtos comuns. É uma forma de embutir mais valor em um mercado; uma forma de estimular negócios e comércio; $\mathrm{e}$, nas mãos certas, um instrumento extrema- mente poderoso para disseminar mudanças sócio-culturais. ${ }^{964}$ 


\section{Capítulo 5 Tema e arquitetura na cultura contemporânea}

"Ela [a casa] proporcionou não apenas refúgio físico
mas também psicológico. Tem sido uma guardiã da
identidade. Ao longo dos anos, seus donos retorna-
ram depois de períodos de ausência e, olhando ao
redor, lembraram quem eles eram."1

Alain de Botton

"A fragilidade e a condição eternamente provisória da identidade não podem mais ser ocultadas" ${ }^{2}$

Zygmunt Bauman

Introdução Este capítulo pretende avaliar os rumos que vem to-

1. BOTTON (2007) pp.10-11.

2. BAUMAN (2005) p.22. mando o modelo temático na contemporaneidade. Primeiramente, será analisada a relação entre o temático e a construção identitária, questionando o entendimento do conceito de identidade, no sentido de discutir a busca pelo diferencial, culminando com a cultura do fake. Em seguida, será colocado o contraponto, com a situação recente de retorno à busca por autenticidade e personalização.

Considerando esta tendência, a seção seguinte pretende mostrar que, ainda que o temático explicitamente alegórico e figurativo faça cada vez menos sentido, sua existência teve reflexos em aspectos característicos fundamentais na produção arquitetônica contemporânea. Ainda que não diretamente, críticos e profissionais consagrados vêm mencionando referências ao temático na produção atual.

5.1 Vimos que a exploração alegórica de um tema é utiIdentidade e lizada, especialmente no espaço urbano, como instrumento autenticidade para construção de identidades. Freqüentemente é levantada a seguinte questão: $O$ tema constrói ou desconstrói identidades? Antes de avançar neste campo, cabe pensar se existe esta identidade almejada, afinal o que é identidade?

3. BAUMAN (2001) Quando Bauman fala em "modernidade líquida"3 nos lembra que vivemos em um momento em que os conceitos são cada vez menos rígidos e as relações menos estanques. Já 
4. FERREIRA (1999) p.1071

5. BUENO (1984) p.581.

6. BAUMAN (2005) p.17. não podemos pensar em uma estrutura fixa, e sim em uma rede mutável de conexões, na qual as definições escapam pelas mãos tal como água. Portanto, para falarmos em identidade é fundamental, em primeiro lugar, deixar claro que a identidade, segundo a definição clássica simplesmente não existe. A definição do termo no dicionário Aurélio diz que identidade é:

\footnotetext{
“1. Qualidade de idêntico; 2. Conjunto de caracteres próprios e exclusivos de uma pessoa: nome, idade, estado, profissão, sexo, defeitos físicos, impressões digitais, etc. 3. O aspecto coletivo de um conjunto de características pelas quais algo é definitivamente reconhecível ou conhecido(...)." ${ }^{4}$
}

O último item interessa especialmente a esta argumentação. Será que existe este conjunto de características permanentes segundo as quais seja possível reconhecer alguma coisa? O Dicionário Escolar da Língua Portuguesa chega a incluir entre suas definições a de "conjunto de elementos que permitem saber quem uma pessoa é" 5 Seria possível que existissem elementos capazes de permanentemente permitir saber quem é uma pessoa? Bauman mostra que nossas identidades estão em transformação continua:

"Tornamo-nos conscientes de que o "perten-
cimento" e a "identidade" não têm a solidez
de uma rocha, não são garantidos para toda
a vida, são bastante negociáveis e revogáveis,
e de que as decisões que o próprio indivíduo
toma, os caminhos que percorre, a manei-
ra como age - e a determinação de se man-
ter firme a tudo isso - são fatores cruciais
tanto para o "pertencimento" quanto para a
"identidade"

Analogamente, estão em modificação constante as chamadas identidades locais. Assim, a idéia de que devemos resgatar identidades locais ao invés de impor uma construção arbitrária somente faz sentido se a relação com esta suposta identidade ainda for presente naquela sociedade. Caso contrário, esta identidade original já não existe, tendo evoluído para um novo sistema de relações. Bauman afirma que a menção da palavra "identidade" remete à batalha, que se a ouvimos certamente se trata de alguma espécie de disputa. O termo é citado 
7. HALL, Stuart. Culture, Community,

Nation. Cultural Studies 3, 1993. pp.349-363. In. BAUMAN (2005)

p.105. como instrumento de defesa, tanto por indivíduos pressionados por grupos ou grupos menores pressionados por uma totalidade "maior", quanto por grupos maiores que evocam a identidade no sentido de acatar as diferenças, mas suplantá-las em nome de uma coletividade maior. O sociólogo alerta para o perigo que reside em adotar a identidade local como arma no combate aos problemas globais, citando Stuart Hall:

"Já que a diversidade cultural é, cada vez mais, o destino do mundo moderno, e o absolutismo étnico, uma característica regressiva da modernidade tardia, o maior perigo agora se origina das formas de identidade nacional e cultural - novas e antigas - que tentam assegurar a sua identidade adotando versões fechadas da cultura e da comunidade e recusando o engajamento... nos difíceis problemas que surgem quando se tenta viver com a diferença." ${ }^{7}$

A preocupação de Hall e Bauman é, evidentemente, mais profunda, englobando as conseqüências do radicalismo cultural e religioso, mas podemos associar suas afirmações à proposta de reconstrução de identidades locais. Não que o perigo tenha proporção equivalente, mas simplesmente porque hoje já não faz sentido ignorar as influências externas e as relações estabelecidas entre o local e o global.

Retomando a questão que iniciou este capítulo, concluímos que o entendimento de que o tema desconstrói identidades pressupõe que a identidade é algo estanque, a ser destruído pelo temático, quando na verdade trata-se de algo constantemente em construção. Portanto, não falamos em identidades prontas e delimitadas, sendo impossível afirmar que o temático pode ser utilizado para a definição de uma identidade, conforme afirma Derrida, citado por Mugerauer:

“(...) o mundo é um tecido de traços que só têm existência autônoma como "coisas" porque se referem ou se relacionam uns com os outros. Por isso, eles são "signos", já que na qualidade de signos o seu "ser" sempre está em outro lugar (porque um signo é sempre o signo de alguma coisa que não ele mesmo; ele não pode referir-se a outra coisa [...] Nenhuma entidade [...] tem uma existência singular [...] fora da rede de relações e forças em que está 
8. DERRIDA, Jacques. Speech and Phenomena. Evanston: Northwestern University Press, 1973. p.104. In MUGERAUER, Robert. Derrida e depois. In. NESBIT'T (2006) p.203. situada. A coisa em si sempre escapa.",

Mugerauer analisa a afirmação de Derrida, exemplificando com uma visita às pirâmides de Gizé. Podemos supor entender o significado de uma foto das pirâmides em uma visita ao local, mas só recuperamos uma parte do significado original que está disponível em documentos. Sem eles, a estrutura estaria completamente desvinculada do passado, portanto, o monumento se mantém significativo somente em função de uma rede de linguagem que tecemos. Mais do que afirmar que todo significado é cultural, Derrida afirma que a cultura em si é o processo histórico de impor e substituir conceitos. Podemos, então, dizer que a exploração urbana do temático direciona o processo contínuo de construção de identidade local.

Este processo está associado à busca por status, algo comumente atribuído a pessoas, aqui estendido ao local. De Botton define status como "o valor e a importância de uma 9. BOTTON (2004) p.7. pessoa aos olhos do mundo"' e, de fato, o que se procura ao propor a valorização de identidades locais é justamente a valorização da forma como o local é visto pelos seus habitantes e pelo resto do mundo. Os benefícios que decorrem de status elevado são incontáveis:

\footnotetext{
"As conseqüências do status elevado são agradáveis. Incluem recursos, liberdade, espaço, conforto, tempo e, talvez tão importante quanto tudo isso, a consciência de que se é considerado valioso e merecedor de cuidados - alvo de convites, adulações, risos (mesmo quando a piada não tem graça), deferência e atenção.

O status elevado é considerado por muitos (mas poucos admitem abertamente isso) um dos melhores bens terrenos." 10
}

10. Idem p.7.

Talvez, no caso das cidades, os benefícios sejam mais econômicos, conforme vimos através das afirmações de 11. Ver Capítulo 4.2 Anholt. ${ }^{11}$ Entretanto, sentir-se parte de uma comunidade de status elevado pode atender, em parte, ao desejo de status de seus integrantes.

Bauman afirma que a mídia permite que os que não têm acesso à versão real tomem emprestado o status daqueles a que assistem na TV. Se, por um momento, todos usam a 
mesma calça ou ouvem a mesma música, ficam virtualmente 12. BAUMAN (2005) pp.102-105. igualados. ${ }^{12} \mathrm{O}$ mesmo acontece em relação ao turismo - aqueles que não possuem os meios para viajar podem se satisfazer com as imagens oferecidas pela TV.

É fundamental diferenciar consumismo e consumo. Se o consumo é uma necessidade inerente à condição humana, o consumismo é uma característica da sociedade. A "sociedade de consumo" se consolida quando o consumo substitui o trabalho, elemento-chave na "sociedade dos produtores". O consumo deixa de ser uma atividade necessária e corriqueira para tornar-se o principal foco da vida das pessoas. A segurança é substituída pelo desejo de consumir como aspiração desta 13. BAUMAN (2008) pp.38-44. sociedade. ${ }^{13}$

A conseqüência é a conversão de pessoas em mercadorias:

14. Idem p.13. Grifo do autor

\begin{abstract}
“(...) todas [as pessoas] aparentemente tão distintas, são aliciadas, estimuladas ou forçadas a promover uma mercadoria atraente e desejável. Para tanto, fazem o máximo possível e usam os melhores recursos que têm à disposição para aumentar o valor de mercado dos produtos que estão vendendo. E os produtos que são encorajados a colocar no mercado, promover e vender são elas mesmas.

São, ao mesmo tempo, os promotores das mercadorias $e$ as mercadorias que promovem. São, simultaneamente, o produto e seus agentes de marketing, os bens e seus vendedores. (...) todos habitam o mesmo espaço social conhecido como mercado. (...) a atividade em que todos estão engajados é o marketing. O teste em que precisam passar para obter os prêmios sociais que ambicionam exige que remodelem a si mesmos como mercadorias, ou seja, como produtos
\end{abstract} que são capazes de obter atenção e atrair demanda e fregueses." 14

Portanto, Bauman vai além, afirmando que mais do que status, as pessoas desejam, e precisam, valorizar-se enquanto mercadorias. Esta valorização inclui o corpo, o intelecto, as posses, enfim tudo aquilo que pode identificar uma pessoa em nosso tempo. A necessidade de remodelar-se constantemente decorre da necessidade de vender-se para públicos diferentes. 
15. BOTTON (2007) p.13.

16. Ver Capítulo 1.5.
Bauman cita tanto um adolescente que se vende em um website de encontros amorosos quanto um candidato à imigração que se vende ao governo do país para onde deseja ir.

Nesta busca por status e valorização pessoal enquanto marca é fundamental ter o mesmo que todos, mas é diferencial ter aquilo que ninguém tem. Ou, ainda, aproximarmonos desta diferença e a arquitetura, como todos os bens, pode ajudar a transmitir a diferenciação. Como disse Alain de Botton:

\footnotetext{
"A premissa para se acreditar na importância da arquitetura é a noção de que somos, queiramos ou não, pessoas diferentes em lugares diferentes - e a convicção de que cabe à arquitetura deixar bem claro para nós quem poderíamos idealmente ser." 15
}

O mesmo podemos estender à moda, design, etc, ou seja, à toda cultura visual.

Nesta lógica, o tema é inserido no estabelecimento comercial em busca de algo que o diferencie dos demais, atraindo atenção de potenciais freqüentadores. Por isso, há um cuidado específico em propiciar vários níveis de percepção, com novos detalhes que garantam o interesse do cliente pelo maior tempo possível. ${ }^{16}$ No entanto, é gerada também uma necessidade de transformação constante que dificilmente pode ser atendida pelo modelo temático. Grandes complexos, como os do grupo Disney e Universal, ainda que mantenham a temática principal ao longo dos anos, estão em constante renovação, seja pela construção de novos parques compondo o conjunto, seja pela reforma para atualização de áreas temáticas, ou mesmo pela substituição de brinquedos e acréscimo de novos personagens. No parque da Disney World, Magic Kingdom, a área temática Tomorrowland, que pretendia proporcionar uma viagem à tecnologia do futuro, foi completamente reformada em 1995. Afinal, a visão de futuro que apresentava era a vigente na época da construção do parque, uma visão que hoje parece datada, remetendo mais ao passado que ao futuro. Para não incorrer no mesmo erro foi feita a opção por não prever o futuro, mas representá-lo como em uma história de ficção científica dos 17. DUNLOP (1996) pp.130-145. anos 30 ou $40 .{ }^{17}$

Os grandes cassinos de Las Vegas com freqüência ga- 
nham novos detalhes ou, muitas vezes, são substituídos. Recentemente, o hotel cassino Aladdin, inspirado nos contos das mil e uma noites, deu lugar ao Planet Hollywood, inspirado na indústria cinematográfica e seus artistas. É preciso oferecer novas atrações para garantir o retorno do visitante. Outros estabelecimentos não permitem esta flexibilidade, o que leva a crer que há um prazo de validade no temático. Vários dos restaurantes/bares/boites já citados neste trabalho fecharam após curto período de funcionamento - Fashion Cafe, Café do Gol, etc.
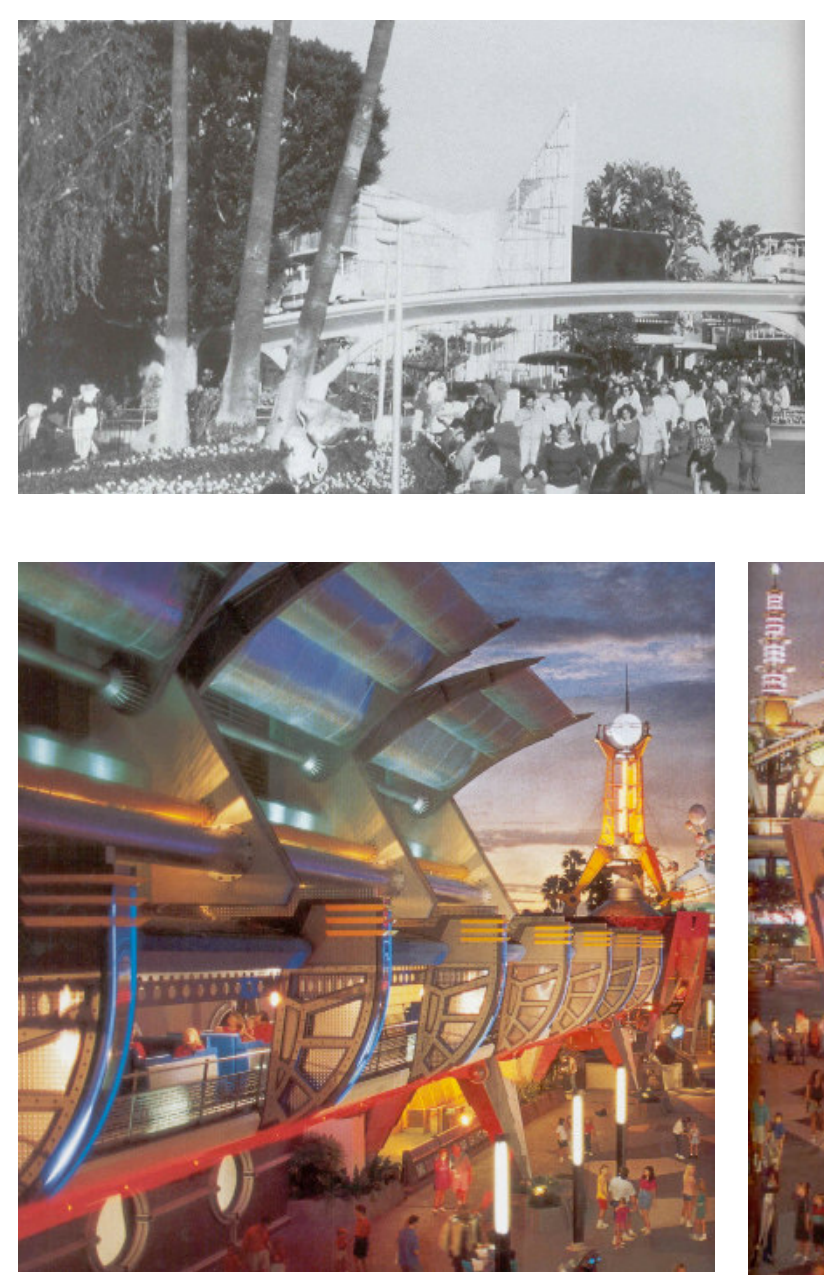

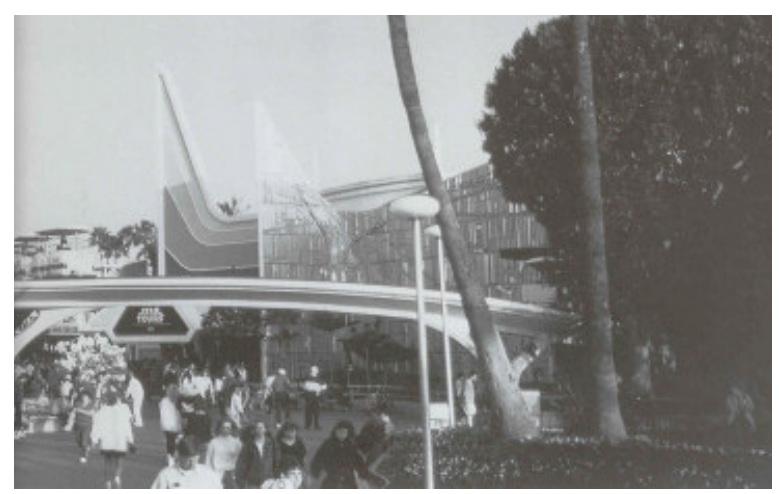

Figs 1 e 2. Tomorrowland antes da reforma.

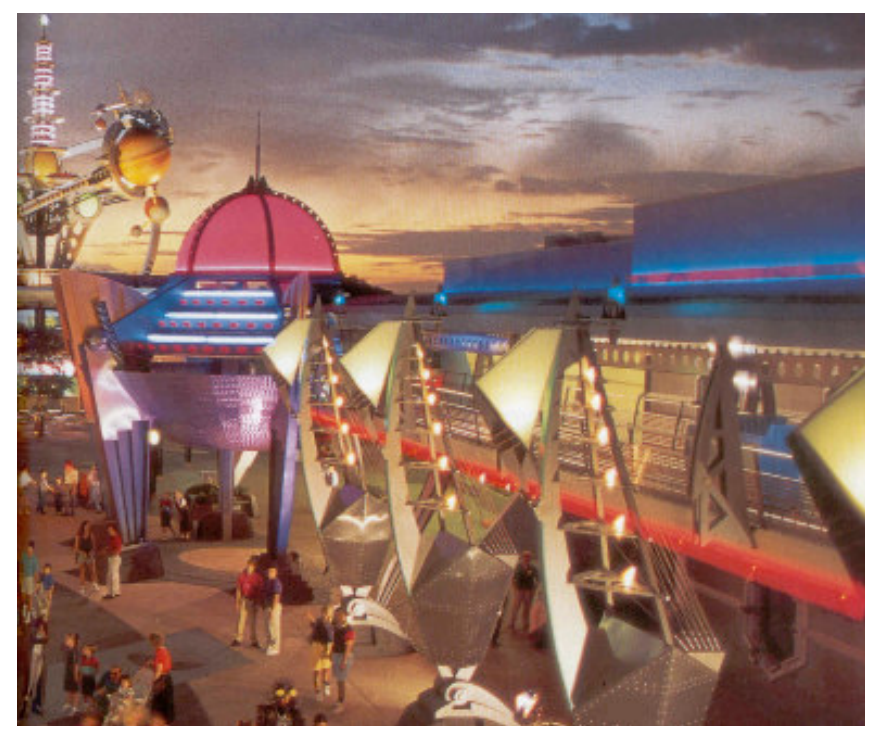

Figs 3 e 4 . Tomorrowland após a reforma.

Utiliza-se, ainda, a reputação de espaços consolidados através do sistema de franquias de bares temáticos que se espalham pelo mundo. Entre eles, os conhecidos Hard Rock Cafe, Planet Holywood, Rain Forest Cafe, All Star Cafe, etc, todos essencialmente similares. Por outro lado, apenas locais com potencial turístico recebem filiais de cadeias de restaurantes temáticos. Esse "direito" a alocar um desses restaurantes con- 


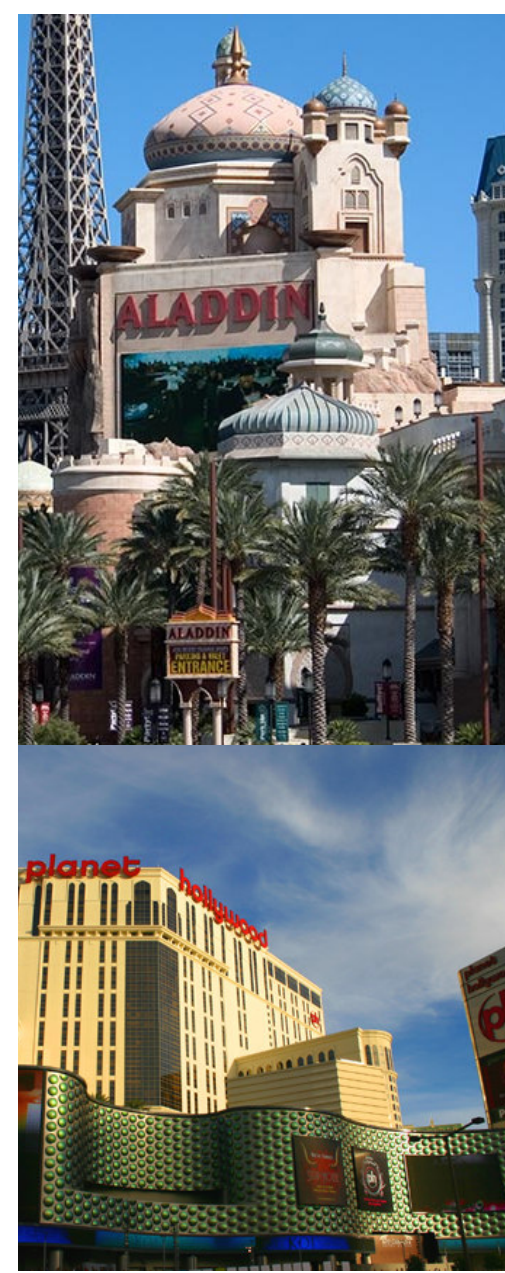

Figs 5 e 6 . Hotéis Aladdin e Planet Hollywood.

18. BAUMAN (2005) p.70.

fere status à cidade em que são construídos. Numa sociedade em que os objetivos principais são a fama, o reconhecimento, e o lucro que deles advém, os espaços se colocam como símbolos de status tanto para quem os freqüenta quanto, principalmente, para quem se torna tema do estabelecimento. Para o freqüentador, o tema se torna questão de status, atribuindo ao espaço características que o valorizem e que, conseqüentemente, são estendidas aos visitantes. Pode-se, inclusive, atrelar a vida útil de um estabelecimento temático à popularidade do tema explorado. Temas consolidados originam estabelecimentos provavelmente duradouros, enquanto temas frágeis, efêmeros, como celebridades instantâneas, por exemplo, reduzem o ciclo de vida do empreendimento, podendo levá-lo à falência precoce. Bauman analisa a substituição constante de produtos na cultura contemporânea:

"O "modo consumista" requer que a satisfação precise ser, deva ser, seja de qualquer forma instantânea, enquanto o valor exclusivo, a única "utilidade", dos objetos é a sua capacidade de proporcionar satisfação. Uma vez interrompida a satisfação (em função do desgaste dos objetos, de sua familiaridade excessiva e cada vez mais monótona ou porque substitutos menos familiares, não-testados, e assim mais estimulantes, estejam disponíveis), não há motivo para entulhar a casa com esses objetos inúteis." 18

Ainda que Bauman esteja falando sobre as relações amorosas, o faz em analogia ao consumo de bens que pode igualmente ser transposta ao consumo de experiências. Os bens, materiais ou imateriais, devem promover satisfação instantânea, estando prontos para consumo imediato. Tão logo cesse o entusiasmo gerado, é feita sua substituição por outro mais instigante e assim sucessivamente. Bauman retoma o conceito de "cultura agorista" de Stephen Bertman para descrever a sociedade em que cada oportunidade é única e pontual, em que a necessidade de "descartar e substituir" se sobrepõe à de 19. BAUMAN (2008) pp.45-50. "adquirir e juntar"19.

A maioria dos estabelecimentos temáticos ganha longevidade por ser voltada ao turismo, tendo seu público renovado constantemente, o que demanda reformulações menos 
freqüentes. Da mesma forma, a exploração temática do espaço urbano costuma ter o turismo como objetivo, porém em comparação a um bar ou loja, fica bem mais difícil a renovação de uma cidade inteira. Provavelmente por isso, no caso das cidades, a exploração figurativa na arquitetura seja mais discreta, com maior enfoque nas celebrações e eventos que acompanham a temática adotada.

Portanto, a arquitetura hoje já não objetiva a beleza, mesmo porque já não há regras que a definam. No classicismo, havia notável semelhança entre as construções e consenso sobre como construir uma janela, porta, etc. Agora, a busca é acima da beleza, por diferenciação e, como vimos, uma das alternativas encontradas para atender esta demanda foi recorrer ao fake, especialmente em locais de foco comercial.

Assim, a aplicação de temas, tanto em estabelecimentos comerciais quanto no espaço urbano, almeja diferenciação. Entretanto, por mais que os locais temáticos sejam constantemente remodelados, podemos ter chegado a um ponto em que quase tudo parece temático e, portanto, semelhante. Ainda que explorem temáticas distintas, há uma aproximação em função da onipresença do temático, fazendo com que a alternativa possível para garantir diferenciação seja rejeitar este modelo. Se passamos a aceitar o fake, adotando uma atitude quase blasé em relação ao espaços assumidamente cenográficos, a tendência seguinte é acreditar que o autêntico nos diferencia.

20. GILMORE e PINE II (2008)

Segundo Gilmore e Pine $\mathrm{II}^{20}$, as decisões de compra estão cada vez mais dependentes do nível de autenticidade das ofertas, de quão reais ou falsas são. Traçando um paralelo, os autores afirmam que se a ascensão dos serviços no mundo pós-industrial originou a demanda por qualidade, a prevalência atual da experiência como produto demanda a autenticidade. Mas o que é autenticidade? O dicionário Aurélio define 'autêntico' como:

"1.Que é do autor a que se atribui. 2.A que se pode dar fé, fidedigno. 3. Que faz fé. 4. Legalizado, autenticado. 5. Verdadeiro, real. 6.

21. FERREIRA (1999) p.233. Genuíno, legítimo, lídimo. (...”²1

Porém, como determinar a legitimidade de algo? Para o consumidor, o produto autêntico seria aquele cuja repre- 
22. GILMORE e PINE II (2008) sentação vai de encontro à sua própria imagem, aquele que se p.6. alinha à sua subjetividade:

\begin{abstract}
"Não mais satisfeitos apenas com ofertas disponíveis, acessíveis e superiores, tanto os consumidores quanto os clientes organizacionais hoje compram produtos e serviços com base no quanto essas compras estão de acordo com sua própria auto-imagem. O que compram deve refletir quem eles são e quem desejam ser em relação a como percebem o mundo com decisões praticamente instantâneas em relação ao que é "real" e ao que é "falso". 22
\end{abstract}

Portanto, autêntico não é necessariamente verdadeiro. Gilmore e Pine II dizem que a empresa deve "administrar a percepção de autenticidade pelo cliente", evidenciando que, mesmo se tratando de autenticidade, importa mais que algo 23. Idem p.4. seja percebido como autêntico do que realmente o seja. ${ }^{23}$ Por24. Ibidem p.12. tanto, há uma clara diferença entre a falta de autenticidade e a artificialidade. Tal distinção é explicita no exemplo citado de um menino que, ao visitar o Animal Kingdom, misto de parque temático e zoológico do complexo Walt Disney World em que há animais de verdade, questiona se são animatronics. Diante da resposta negativa, o menino pergunta quando irá à Disney de verdade. ${ }^{24}$ Ou seja, a percepção do autêntico é bastante pessoal; o menino sentiu-se traído pelo produto comprado porque no contexto de um parque temático animais de verdade não são autênticos, não se alinham à imagem que se faz, e é vendida, do local.

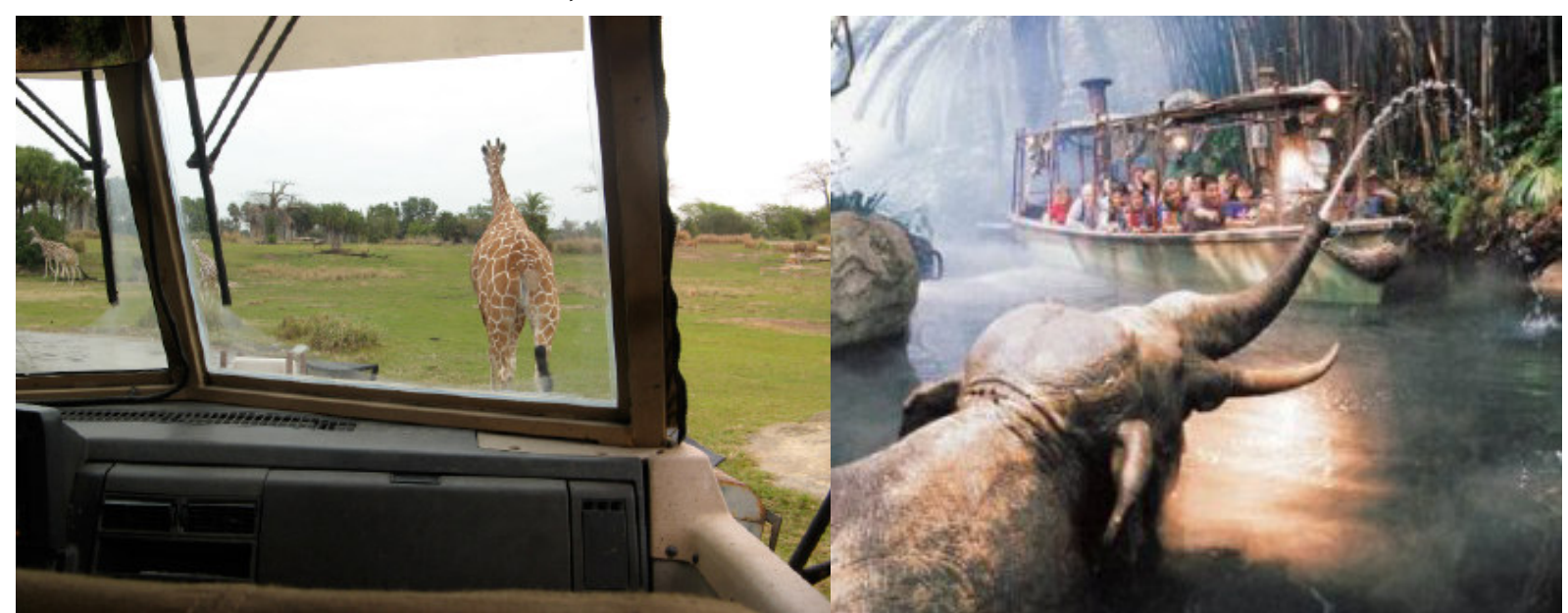

Figs 7 e 8. Safári com animais reais no Animal Kingdom e animatronics no Magic Kingdom.

Palavras como real, autêntico e verdadeiro são usadas constantemente pela publicidade de produtos diversos, sim- 


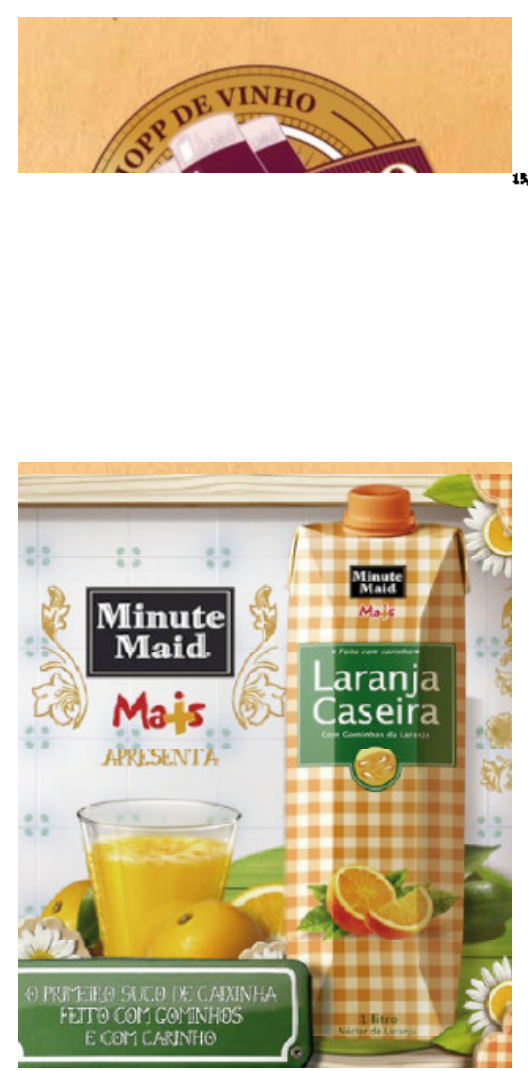

Figs 9 e 10. Chopp de Vinho 'Antêntico' e suco 'Laranja caseira'.

25. Minute maid Mais Laranja Caseira, da Coca cola Company. Possui 67\% de suco na fórmula e gominhos de laranja, disponível nas versões normal e diet. In. www. minutemaid.com.br

26. Biscoito recheado Doce Sabor, Marilan. In. www. marilan.com.br

27. As pias das cozinhas

Magic Toys têm água de verdade, as hélices do liquidificador e da batedeira funcionam de verdade. In. www.magictoys.com.br.

28. Autêntico, o primeiro chopp de vinho do Brasil. In. www. oautentico.com.br

29. A marca esportiva Rainha vende reedições de modelos antigos sob a marca 'Rainha

Autêntico’. Ver www.lojavirtual/ rainhaautentico.com.br plesmente pelo fato de que as pessoas compram. O suco de laranja artificial tem gominhos de verdade ${ }^{25}$, o biscoito recheado tem o autêntico sabor de limão ou de $\operatorname{coco}^{26}$, os brinquedos funcionam de verdade ${ }^{27}$, o chopp de vinho é autêntico ${ }^{28}$ e o tênis vintage é autêntico ${ }^{29}$. Por mais que saibamos que se tratam de produtos industrializados, com aroma e sabores sintéticos ou recriações, parece que o rótulo de autenticidade impressiona positivamente o consumidor.

A televisão acompanha (ou origina?) esta tendência, com a tomada da programação por reality shows. A fórmula caracteriza-se por incluir pessoas desconhecidas e pela ausência de roteiro e direção, propondo exibir a "vida real"; entretanto, a edição detalhada e a ciência por parte do participante de que está sendo televisionado fazem com que, obviamente, o resultado difira muito da vida longe das câmeras. O pioneiro Real World (1992), da MTV, fórmula reeditada no Brasil sob o titulo "20 e poucos anos", juntava jovens de personalidades e passados diferentes para conviver em um mesmo espaço, explorando os conflitos gerados com sua interação. Desde então, a fórmula tem gerado frutos que exploram a sobrevivência em situações extremas (No Limite, de 2001, o pioneiro no Brasil), interação e disputas entre desconhecido (Big Brother, Casa dos Artistas), competições de talentos (Fama, Ídolos, Astros, Pospstar), disputa por perder peso (O Grande Perdedor), cuidados com crianças (Supernanny), gincanas simulando processo seletivo para emprego (O Aprendiz), só para citar alguns dos shows produzidos no Brasil nos últimos anos.

O modelo reality show transformou-se em tábua de salvação para programas que enfrentam problemas de audiência. A programação tradicional tem incluído blocos de reality em uma espécie de "venda casada" em que o espectador assiste o programa para acompanhar os quadros. Dentre os exemplos mais populares, o programa "Domingão do Faustão", com a "Dança dos Famosos", a "Dança no Gelo" e o "Circo do Faustão", o "Caldeirão do Huck" com os quadros "Lata velha", "Lar Doce Lar", "Acorrentados" e "Guerra do Sono" e, recentemente o programa "Mais Você", com o "Super Chef", todos reproduções de produções internacionais bem sucedidas. Nos Estados Unidos, o posto de maior audiência costuma 
30. www.nielsenmedia.com

31. GILMORE e PINE II (2008) pp.57-98

32. www.natura.com.br Anúncio da linha Natura Ekos, veiculado na edição n.545 da Revista Época, Editora Globo, 27 de outubro de 2008. "Você é a obra mais perfeita da natureza. Todos os seus milagres, todos os seus mistérios estão reproduzidos em você.

Todo conhecimento. A floresta está em você. Preste atenção nas vozes dos pássaros, das árvores, dos rios dentro de você. Você é responsável por suas escolhas. Siga sua sabedoria." ser ocupado pelo gênero, na temporada 2006-2007, dentre os dez primeiros colocados no ranking de audiência seis eram realities, segundo o Nielsen Ratings. ${ }^{30}$ Portanto, parece que o público enxerga autenticidade nos programas.

Gilmore e Pine II, identificaram cinco características que fazem com que o consumidor perceba algo como autêntico $^{31}$. A primeira se refere à naturalidade, segundo a qual as pessoas percebem como autêntico aquilo que não foi tocado pelas mãos humanas, ou não é sintético. Este apelo é evocado por marcas que vendem produtos orgânicos ou feitos com ingredientes naturais, caso da Natura, com seus cosméticos produzidos com frutas amazônicas e proclamada política de sustentabilidade ${ }^{32}$. A percepção de autenticidade também pode ser relacionada ao caráter original do produto, já que se percebe como autêntico aquilo que é diferente de tudo o que já se viu. O exemplo citado é a marca Apple, cujos produtos destacam-se pela inovação em funcionamento e design. Por ter sido pioneiro e inovador, o iPod é considerado autêntico, enquanto $m p 3$ players de outras marcas são vistos como réplicas não originais. A terceira característica identificada pelos autores é a excepcionalidade, em que serviços bem executados e interesse pelo cliente contribuem para percepção de autenticidade. Seria o caso de lojas em que o cliente é recepcionado com champagne, mas em que os vendedores opinam com sinceridade sobre os produtos.

Em seguida, os autores citados analisam uma característica que interessa particularmente a este trabalho, a 'referência', segundo a qual o consumidor enxergaria autenticidade em ofertas que fazem menção à história humana e memórias de maneira não trivial. Estão incluídas aqui todas as chamadas experiências icônicas - ir a um jogo de futebol no Brasil, tomar uma cerveja na Bavária, uma chá em cerimônia tradicional na China ou um vinho em uma vinícola francesa. Contudo, Gilmore e Pine II mencionam especificamente o temático quando citam o exemplo de Las Vegas. Relatam um programa de TV que entrevistava pessoa que passeavam pela

33. Ver Capítulo 1.3 Strip ${ }^{33}$, perguntando porque gostavam de Las Vegas. Curiosamente, a resposta de muitos era: "Porque é tão real!". Vimos que Las Vegas é, junto com a Disney, o símbolo máximo do 
34. GILMORE e PINE II (2008) inspirador."34 p.86.

temático, precursora do modelo, tida como epíteto do fake. Por que os visitantes a considerariam tão real? Segundo os autores, a maior parte do público de Vegas jamais terá a chance de conhecer a fonte inspiradora dos cassinos e, ao visitar sua segunda opção, vislumbra o original. Entretanto, isto ocorre pelo detalhismo e preocupação dedicados à simulação. Dizem que: "Para elaborar um bom tema, você não precisa ser apenas respeitosamente referencial, mas também convincente e coerente, harmonizando cada aspecto da oferta ao redor do tema

Fazendo a mesma pergunta a freqüentadores do Shopping Barra World, no Rio de Janeiro, as respostas foram bem distintas, variando entre "é perto" ou "é legal para as crianças". O shopping temático inclui áreas que fazem referência a várias partes do mundo - Inglaterra, Itália, França, Alemanha, Holanda, Japão e países Árabes. A decoração de cada área recebe alguns elementos tidos com característicos do local representado, no entanto a proporção, a base em que são aplicados estes pequenos detalhes é idêntica em todo o shopping. Além disso, a recontextualização de referências chega ao ponto de colocar uma réplica da Torre de Pisa às margens de um canal de Veneza - este nada mais que um pequeno espelho d'água com uma única gôndola fixa em que

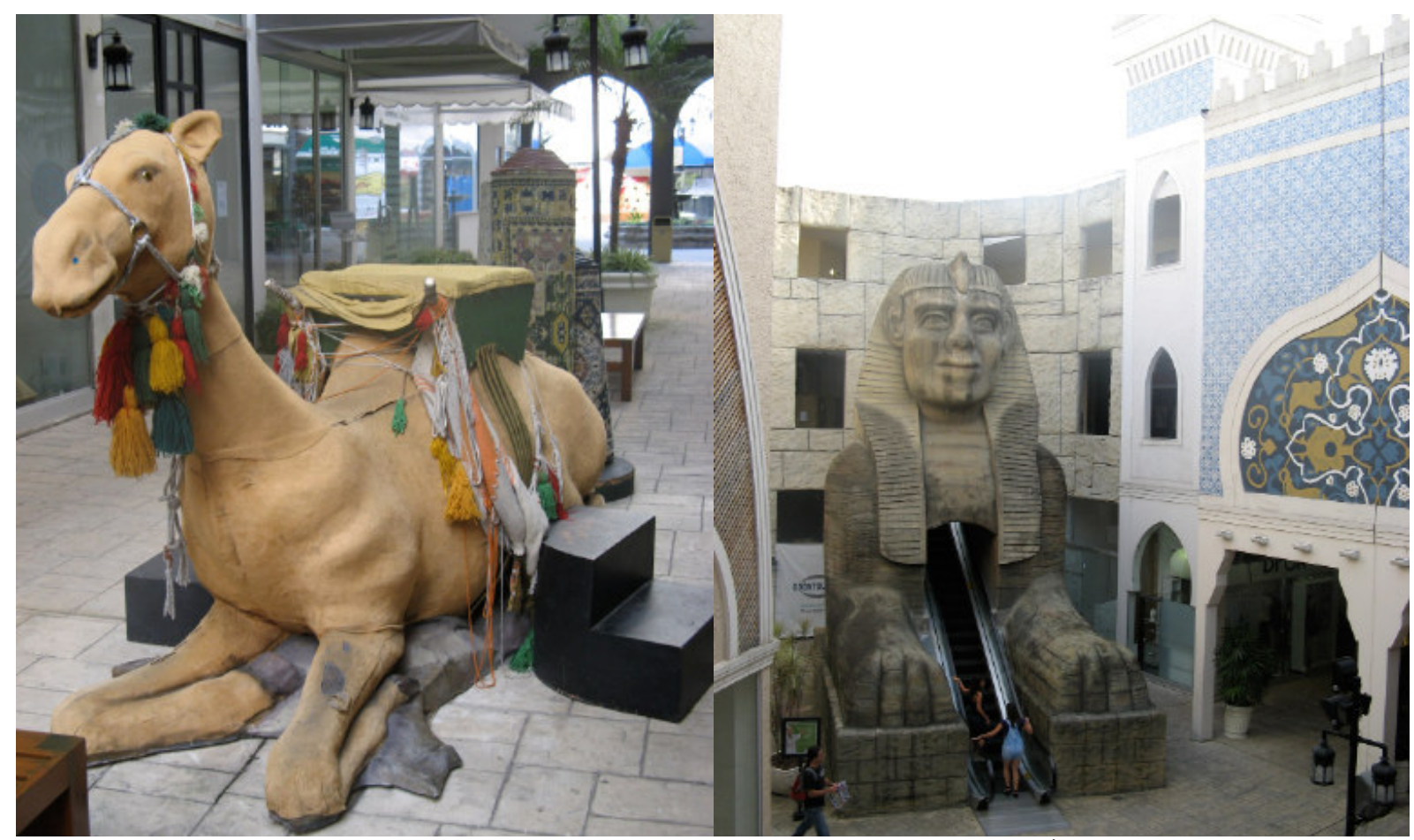

Figs 11 e 12. Mundo Árabe no Shopping Barra World. 
35. O hotel-cassino The Venetian localiza-se na Strip, em Las Vegas. Adota temática que remete à cidade de Veneza, na Itália, incluindo canais com gondoleiros e mármore vindo da Itália para sua construção.

36. PROVOLEDO, Elisabetta Vanishing Venice: a city swamped by a sea of tourists. New York Times, 1 de outubro de 2006. In GILMORE. e

PINE II (2008) p.313.

37. KAY, John. The Magic kingdom could save Venice from Destruction.

Financial Times, 13 jun 2006. In GILMORE. e PINE II (2008) é possível tirar fotos. Se na Veneza de Las Vegas é utilizado mármore italiano, na do Rio de Janeiro é usada fibra de vidro. O "mundo árabe" é representado como se dotado de uma cultura uniforme, com uma réplica da Esfinge - devidamente atravessada por uma escada rolante - situada no centro de uma espécie de praça cercada por arquitetura que remete à cultura árabe. Como resultado, o visitante enxerga no shopping uma grande brincadeira, jamais a simulação de uma viagem ao local representado.

Finalmente, a quinta característica responsável pela identificação de algo como autêntico, a influência, se refere à capacidade do produto de influenciar positivamente outros setores, promovendo melhorias e inspirando o homem. Encaixam-se neste modelo empreendimentos imobiliários auto-sustentáveis, programas de emagrecimento, como o Vigilantes do Peso e, segundo os autores, até mesmo a cadeia de Restaurantes Hard Rock Cafe, com seu slogan "Save the World". Evidentemente, a autenticidade transparece simultaneamente através de mais de uma das características. A já citada marca de cosméticos Natura, por exemplo, associa produtos naturais à proposta de recuperar as comunidades de onde são extraídas as matérias primas e possibilidade de compra em refil, à personalização na venda e, mesmo, à originalidade, em função do uso pioneiro de matérias primas nacionais pouco conhecidas.

Assim, o fato é que aqueles que não podem ir a Veneza, vão ao The Venetian. ${ }^{35}$ Se, para muitos, há um grave distúrbio em equiparar qualitativamente as duas, cabe dizer que, para vários autores, a Veneza italiana é tão artificial quanto a americana. A imagem romântica associada aos canais não é original, já que estes serviam originalmente ao comércio, sendo vistos sob um ponto de vista prático, bem distante da aura de fantasia atual. A cidade é mantida acima do nível do mar apenas com o uso de equipamentos, e cresce a cada dia a proporção de turistas em relação aos habitantes. Os poucos que continuam morando em Veneza dependem do turismo, fazendo com que a cidade se converta em uma "casca vazia" 36 preservada artificialmente. O economista John Kay chegou a sugerir que a cidade fosse administrada pela Disney, afinal "Veneza já é um parque temático" ${ }^{37}$. Ao assumir-se temático o 
The Venetian pode parecer mais autêntico, ao passo que Veneza pode parecer artificial ao manter suas características físicas às custas de mascarar a realidade. Portanto, há aqueles que podem ir a Veneza e preferem ir ao The Venetian e, talvez, não haja mal algum nisso.

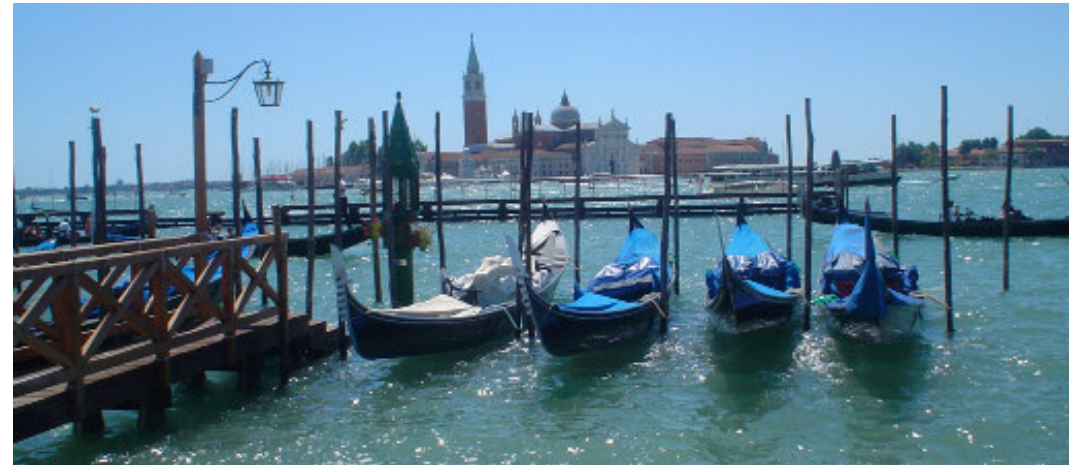

Fig 13. Gôndolas em Veneza.

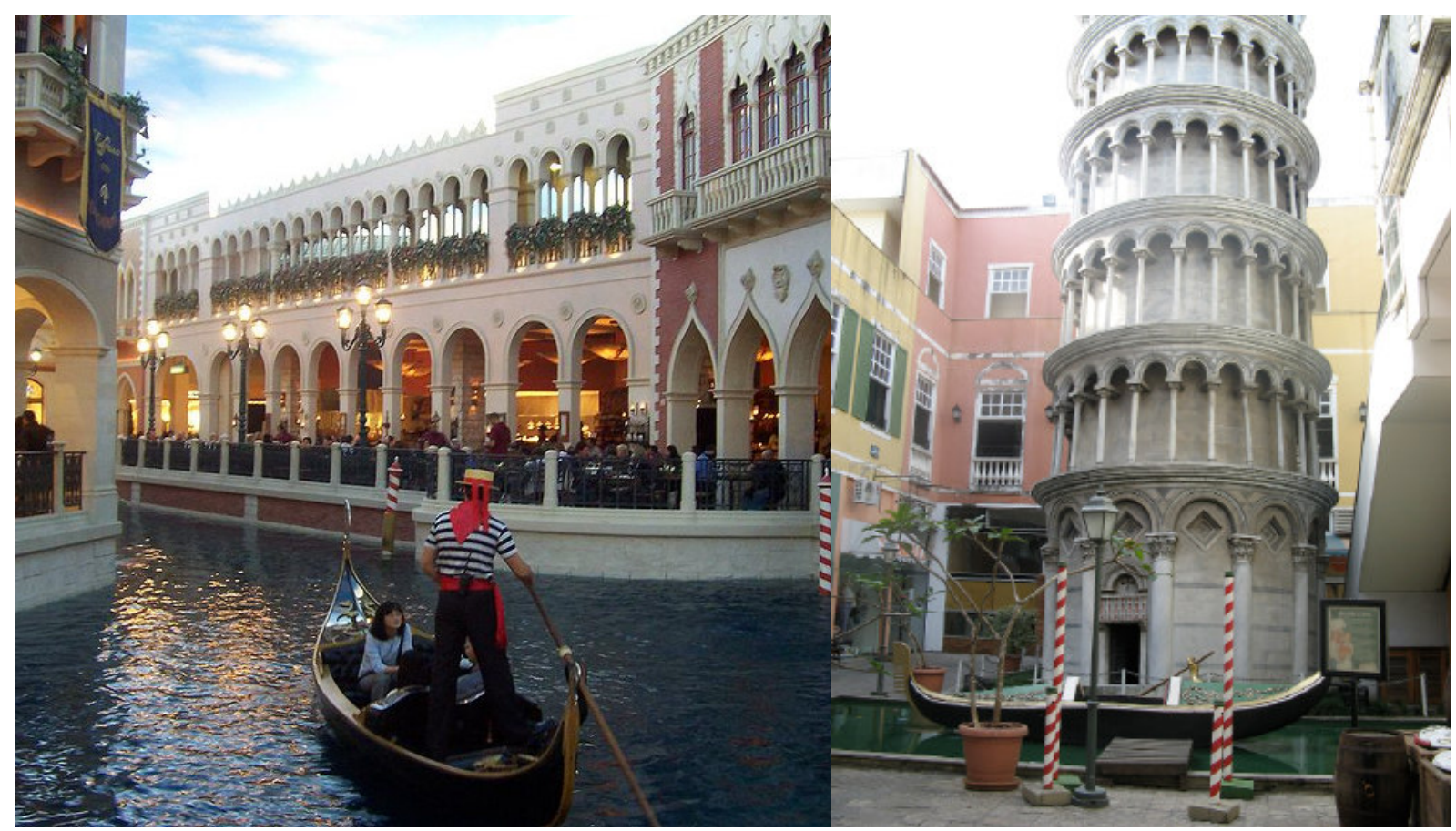

Figs 14 e 15. Gôndolas no The Venetian e no Barra World Shopping.

38. Corrida de cavalos que ocorre em julho e agosto na praça central, mobilizando toda a cidade, que se divide em bandeiras. O Palio atrai milhares de turistas a Siena.

Uma questão semelhante é identificada na Toscana, Itália. Lasansky mostra que a visão que temos hoje sobre a região foi moldada pelo governo fascista, que considerava que, valorizando o Renascimento, estaria elevando o censo de nacionalismo italiano, reforçando uma suposta superioridade cultural e intelectual. Para atingir este objetivo, foi incentivada a reconstrução e restauração de cidades toscanas de acordo com os esteriótipos vigentes sobre a renascença e o período medieval. Em Siena, o Palio ${ }^{38}$, foi remodelado para 
39. LASANSKY, D. Medina. Blurred boundaries between tourism and history: the case of Tuscany. In. FRAUSTO e OCKMAN (2005) p.55.

"Contemporary historians readily admit that history is a product made and remade in a specific time and place that says more about the present than about the past. They acknowledge that the past is constantly being renarrated according to contemporary goals, rethoric and media."

40. O dinner show Medieval Times possui nove "castelos" nos Estados Unidos e Canadá, onde é possível assistir a um espetáculo que se propõe a recriar as batalhas a cavalo do século XI. Enquanto torce por uma das seis bandeiras que participam da competição, o visitante janta com as mãos, já que não existiam talheres na época recriada. In. www.medievaltimes. com parecer mais medieval, coerente com a cidade. Em Arezzo, as fachadas neoclássicas foram remodeladas em "estilo medieval". Assim, ressaltando características que se mostraram interessantes e suprimindo outras, o partido fascista teria remodelado a identidade italiana, em uma visão que permanece. Para Lasansky, é bastante óbvio que se perceba o pastiche em cassinos de Las Vegas, mas é bem mais difícil percebê-lo em Florença, conforme afirma:

"Historiadores contemporâneos admitem,
prontamente, que a história é um produto,
feito e refeito em tempo e local específicos,
e que diz mais sobre o preente que sobre o
passado.Eles reconhecem que o passado está
sendo constantemente renarrado de acordo
com os objetivos, retórica, e mídia contem-
porâneos." 39

Ainda assim, sabemos que ao assistir um dinner show no Medieval Times ${ }^{40}$ estamos presenciando uma encenação, mas acreditamos que assistindo ao Palio de Siena, presenciamos um evento medieval autêntico.

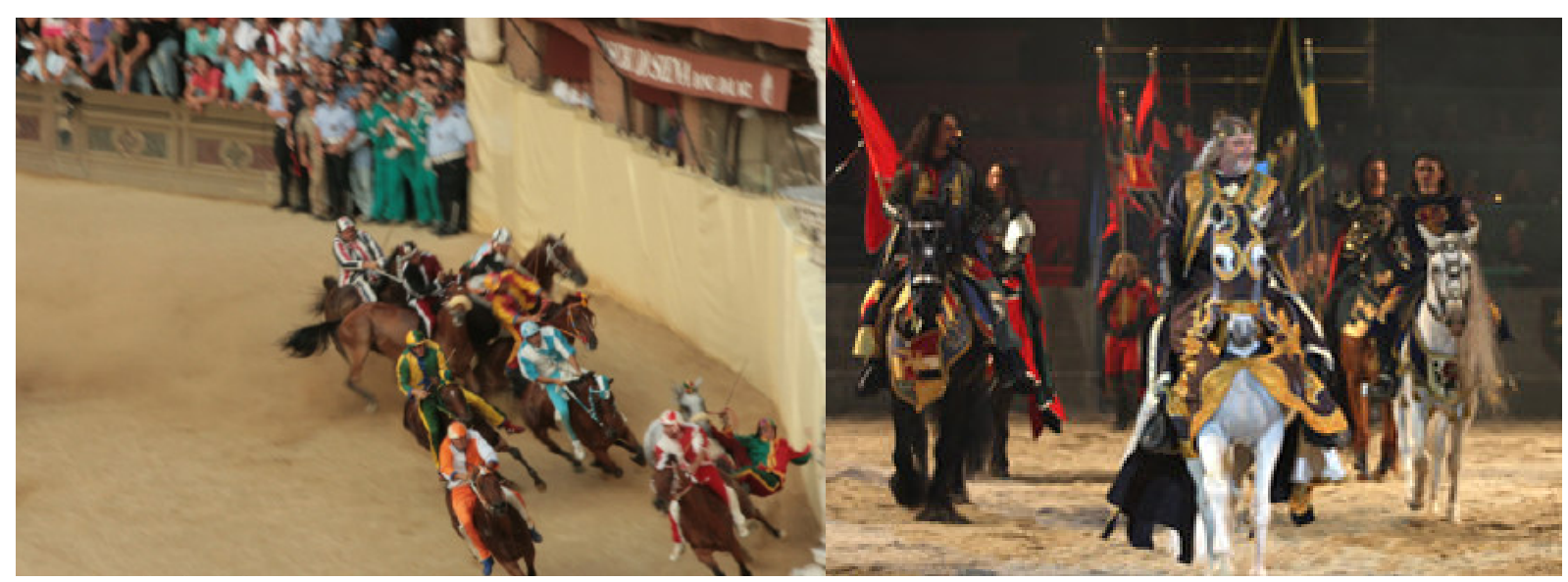

Figs 16 e 17. Palio em Siena e show no Medieval Times.

O mesmo ocorre em campos de concentração. Apresentados como museus que prestam homenagem e não deixam esquecer o massacre, podem facilmente ser equiparados a parques com o tema holocausto. Em Dachau, a poucos quilômetros de Munique, o pavilhão onde ficavam os prisioneiros é reconstruído e inacreditavelmente limpo e novo, lembrando mais um acampamento de férias para jovens. Por mais que existam placas e audio tours informando que se trata de uma reconstrução, a sensação de que não é autêntico prevalece. 
41. YOUNG, James E. The veneration of ruins in the landscape of holocaust memory. In. FRAUSTO e OCKMAN

"(...)with the passage of time, sites and events gradually became estranged from one another. While the sites of

killing remained ever present, all too real in their physical setting, time subtly interposed itself between place nad its past.

Events that occured in another time seemed incresingly to belong to another world altogether. Only a deliberate act of memory could reconnect them, reinfuse the sites

with a sense of their historical past."
Surpreendentemente, o local é belo e tranqüilo, transmitindo inicialmente uma sensação de paz ao invés de desconforto. Visitantes do mundo todo vão ao local procurando identificação com o sentimento gerado pela tragédia. Entretanto, é provável que visitantes sem ligação pessoal direta com a tragédia ou jovens que não vivenciaram o momento, deixem o local pensando que não foi tão terrível quanto contam.

\begin{abstract}
“(...)com a passagem do tempo, locais e eventos se tornam, gradualmente, desvinculados entre si. Enquanto os locais de matança continuam presentes e bastante reais em seu aspecto físico, o tempo sutilmente se interpõe entre o lugar e seu passado. Eventos ocorridos em outra época parecem, cada vez mais, pertencer a outro mundo. Somente um ato deliberado de memória poderia reconectá-los, dotar novamente o local do senso de seu passado histórico." ${ }^{41}$
\end{abstract}

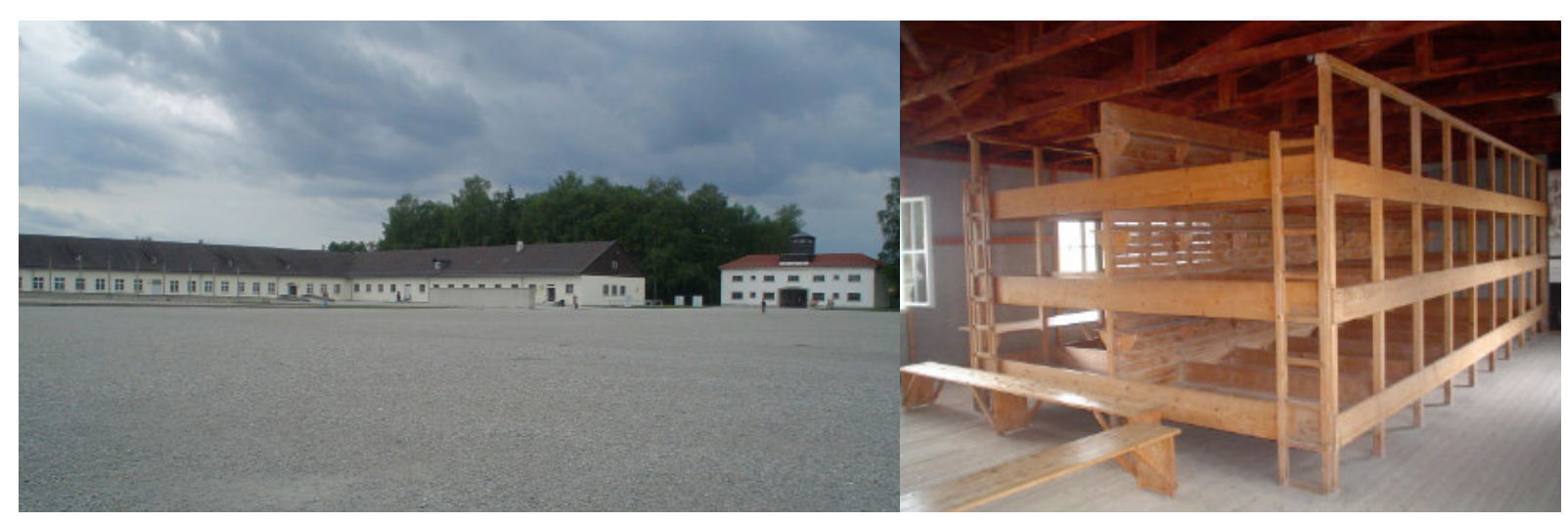

Figs 18 e 19. Campo de concentração em Dachau; Alemanha. Vista geral e reconstrução do alojamento.

42. SCHWARZER, Mitchell. Architecture and mass tourism. In. FRAUSTO e OCKMAN (2005)

p.20.

Schwarzer narra que, em visita ao Egito, conversando com vários moradores, percebeu que a grande maioria evitava freqüentar os locais turísticos e monumentos faraônicos. Para os nativos, estes locais representam não o verdadeiro Egito islâmico, mas um visão recortada de sua cultura, descrita como "uma cruel perversão ocidental" no turístico, seja ele apresentado como museu, preservação histórica ou espaço de lazer, terá sido, ao menos em parte, construído pela visão da época em que é vendido. Não existe a autenticidade total, poderíamos, ao invés, falar em credibilidade.

O fato de Gilmore e Pine II proporem uma espécie de "manual para dotar seu produto de autenticidade" nos leva a 
43. LASANSKY, D. Medina. Blurred boundaries between tourism and history: the case of Tuscany. In. FRAUSTO e

OCKMAN (2005) pp.51-52. “(...) the authentic is a cultural construct that is in a Constant state of flux and redefinition.

It has less to do with past historical reality than with contemporary tastes, trends, and rethoric, whether that rethoric is political, economic or something else. In the end, it is the need to continually monitor and contemporize the "authentic" (through refinement and redefinition) that ultimately generates and sustain tourism."

44. No site da Brastemp é possível escolher as cores e partes que irão compor sua geladeira, montando um modelo "personalizado".

"O Refrigerador Brastemp You pode ser personalizado do seu jeito, você pode escolher a cor, as características internas do produto, e dependendo da combinação, o seu produto pode ser único. Podem ser customizadas: o controle externo com Sexto Sentido, voltagem, dispenser de água externo, lado de abertura da porta, porta latas, compartimento para laticínios, gaveta extra multiuso, prateleira extra.” In. www.brastemp.com.br A rede Build-a-bear funciona em sistema de stands e pequenas lojas, em que o cliente escolhe todas as partes - pele, roupas, tamanho, acessórios, etc - para montar seu próprio animalzinho de pelúcia. Ao final do processo o brinquedo é pesado em uma balança de bebês e o comprador recebe uma espécie de certidão que comprova a criação.

45. MIDDLETON (2002) p.506. pensar se é possível ser, de fato, autêntico. Ainda que não seja este o único enfoque dos autores, que igualmente se propõem a entender o fenômeno, são investigadas formas práticas de tornar o produto autêntico aos olhos do consumidor, afinal, o livro encontra-se na seção de economia e não sociologia ou filosofia. A verdade é que, neste campo, parece valer a máxima de Pirandello, "Assim é... Se lhe parece". A autenticidade está relacionada à percepção pessoal e, como toda "realidade" é, de uma forma ou de outra, manipulada, parece não haver nada que possa ser considerado autêntico sob um ponto de vista universal. Então já não faz sentido a dualidade real x falso, devemos avaliar o nível de autenticidade da imitação.

$$
\begin{aligned}
& \text { “(..) o autêntico é uma construção cultural } \\
& \text { que está em constante estado de fluxo e re- } \\
& \text { definição. Tem menos a ver com a realidade } \\
& \text { do passado histórico que com o gosto, moda } \\
& \text { e retórica contemporâneos, seja esta retórica } \\
& \text { política, econômica ou outra coisa. No fim da } \\
& \text { contas, é a necessidade de continuamente mo- } \\
& \text { nitorar e contemporizar o "autêntico" (através } \\
& \text { de refinamento e redefinição) que definitiva- } \\
& \text { mente gera e sustenta o turismo." }{ }^{33}
\end{aligned}
$$

Buscando atender à demanda por autenticidade, conceitos como personalização e customização tornaram-se corriqueiros. Quando programamos um iPod, escolhemos as cores de nossas geladeiras, montamos nossos próprios animaizinhos de pelúcia, temos a sensação de afirmar nossas personalidades e consideramos que os produtos são autênticos por seu caráter exclusivo $^{44}$. A produção em massa como um processo padronizado é, cada vez mais, superada pela capacidade de personalizar produtos para atender às necessidades individuais, conforme afirma Middleton:
"As idéias tradicionais de consumo em massa e de turismo em massa são irrelevantes na nova economia. (...) O Zeitgeist da nova era, liberado pela "nova economia", é um individualismo agressivo, totalmente livre de qualquer conceito de restrição coletiva (exceto pressão de grupos similares). É o individualismo que sustenta o "novo consumidor" ao qual o marketing deve responder." ${ }^{45}$

Seguindo a idéia de Middleton, Gilmore e Pine II ape- 
nas afirmam que não se trata de um novo consumidor em oposição ao antigo que mantém o padrão de consumo, mas de uma nova forma de consumir adotada por todos.

Concluímos que, junto com a demanda por individualidade, viria a demanda por autenticidade. Como na arte, em que se alterna a prevalência ou repulsa ao ornamento, parece que a busca por diferenciação que culminou no fake teria trazido uma uniformização dos produtos, levando o consumidor a buscar a diferenciação pela autenticidade. Resta saber se este consumidor está preparado para abrir mão da magia permitida pelo fake ou irá consumir réplicas com selo de procedência.

5.2 No contexto da procura por autenticidade, o temático Temático no contexto figurativo e alegórico já não faz sentido, senão em espaços da arquitetura de lazer, mas certamente encontramos reflexos deste modelo, contemporânea tanto na produção quanto na crítica arquitetônica contemporânea.

Houve, durante anos, uma tendência em considerar digna de visita apenas a arquitetura dita histórica. Como diz 46. SCHWARZER, Mitchell. Schwarzer ${ }^{46}$, a arquitetura moderna encontra-se pouco dispoArcbitecture and mass tourism. In. FRAUSTO e OCKMAN (2005) pp.20-23. nível para o turismo, não sendo apresentada em guias, nem explorada pelas cidades que a abrigam. Um ou outro edifício, como a capela Notre Dame du Haut, de Le Corbusier, é visitado por arquitetos e estudantes, mas boa parte dos edifícios modernos que permeiam os livros de arquitetura sequer permite acesso público. A arquitetura moderna enquanto destino turístico permanece negligenciada a especialistas, mas vimos, nos últimos anos, que arquiteturas contemporâneas e, portanto, ainda não históricas, tornaram-se destinos turísticos de abrangência mundial. Esta tendência teve origem com a inauguração do Museu Guggenheim, em Bilbao, projetado pelo arquiteto Frank Gehry. Visitantes que jamais haviam pensado em conhecer a cidade industrial passaram a procurá-la como destino turístico, e logo puderam, além de conhecer o edifício, comprar em lojas de grifes internacionais e comer em restaurantes modernos. A inauguração do museu atraiu o turismo e, com isso, permitiu a revitalização da cidade sob nova vocação.

Vimos no capítulo anterior que, objetivando o turismo, certas cidades são divulgadas seguindo determinados te- 
47. Ver Capítulo 4.2

48. FRAUSTO e OCKMAN (2005) p.9. O livro é baseado na conferência Architourism: Architecture as a destination for tourism, realizada em 2002, pelo Temple Hoyne Buell

Center for the study of American Architecture, na Columbia University.

Os organizadores narram que a conferência foi motivada pelo "Efeito Bilbao".

"We coined the term architourism by analogy to other types of tourism, like ecotourism, art tourism, and heritage tourism, in order to suggest that architecture, in becoming a marketable destination today, now has its own niche in the tourist industry."

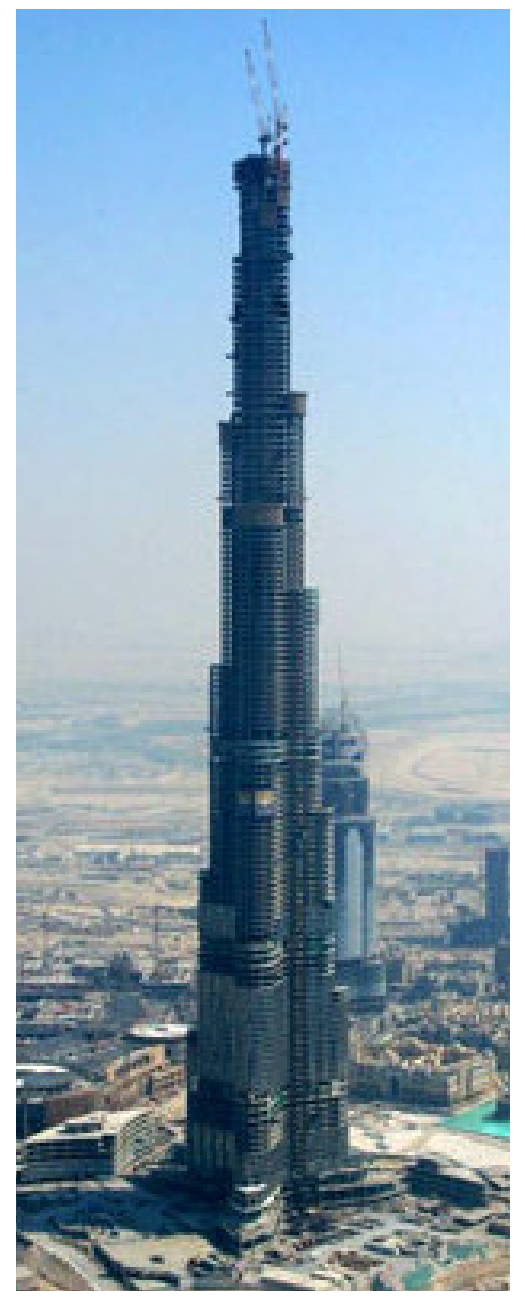

Fig 21. Burj Dubai, em construção.

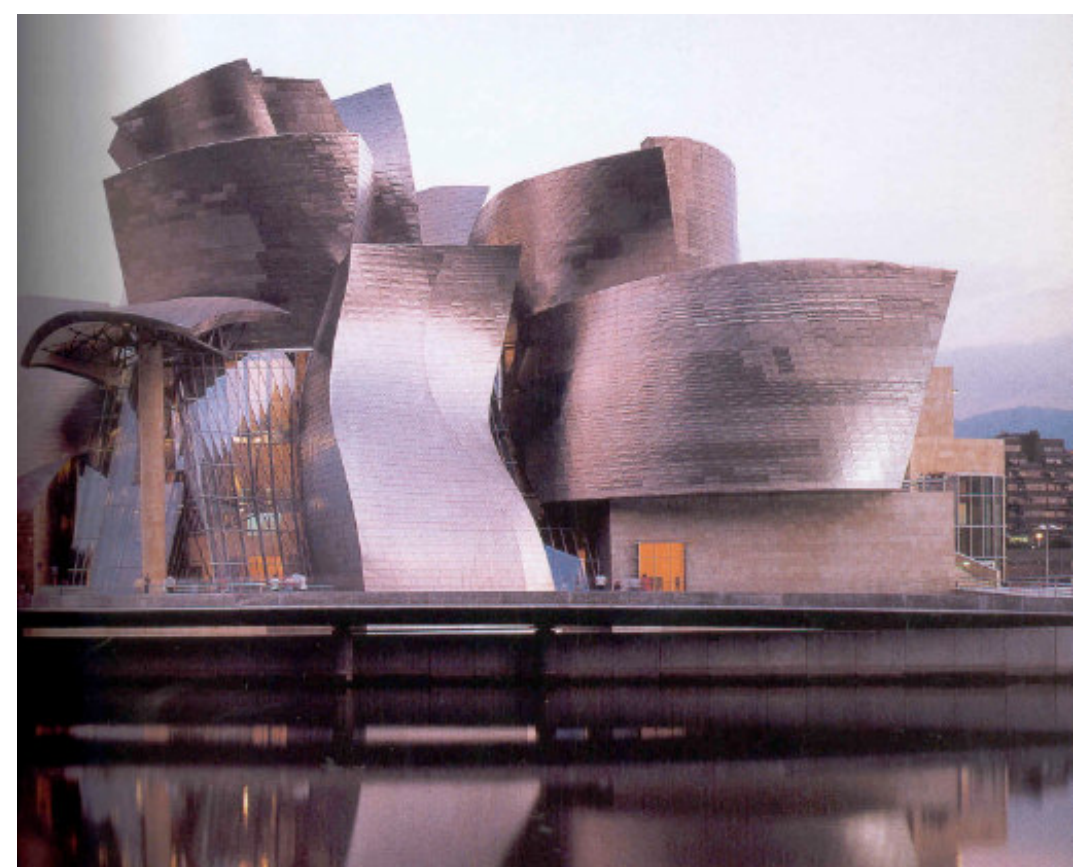

Fig 20. Museu Guggenheim; Bilbao. mas, porém, nos casos citados, nem sempre a arquitetura faz parte do projeto de "tematização" em que justamente o foco principal do visitante são edificações, tendo ou não a cidade em que estão propostas temáticas. Para identificar estes locais e seu enfoque turístico baseado na arquitetura, Ockman e Frausto cunharam o termo architourism que poderia ser traduzido como arquiturismo:

"Nós cunhamos o termo architourism em analogia a outros tipos de turismo, como ecoturismo, turismo de arte, e turismo histórico, para sugerir que a arquitetura, tornando-se um destino vendável, tem hoje seu próprio nicho na indústria turística."

Embora a construção do conceito seja recente, a arquitetura sempre teve destaque sob o ponto de vista turístico e cultural; desde as sete maravilhas da antiguidade, a construção desperta o interesse humano, gerando fluxo de visitantes. Da mesma forma, a conversão da arquitetura em símbolo local remete à catedral medieval, metonímia da cidade. No último século, teve visibilidade a disputa por erguer o edifício mais alto do mundo, tarefa cada vez mais difícil, já que candidatos foram superados mesmo antes de ter sua construção finalizada, com o anúncio do projeto de outra edificação ainda mais alta. Atualmente, o titulo pertence ao Burj Dubai, em Dubai. Ainda em construção, sua altura final não foi divulgada, mas em setembro de 2008 a construção já atingia 688 metros, su- 
49. www.burjdubai.com 50. FRAUSTO e OCKMAN (2005)

51. OCKMAN, Joan. Nine site-seers In. FRAUSTO e OCKMAN (2005)

“(...) architecture has always been an integral part of the tourist's experience. Today, as places increasingly get restructured

as spaces of consumption, and as tourist activities merge with other mass-consumption practices, from shopping and sports to culture and education, architecture is becoming an integral part of the conception and economy of tourism and vice versa. (...) in an advanced consumer society, architecture constructs tourist experience and is in turn constructed by tourist values."

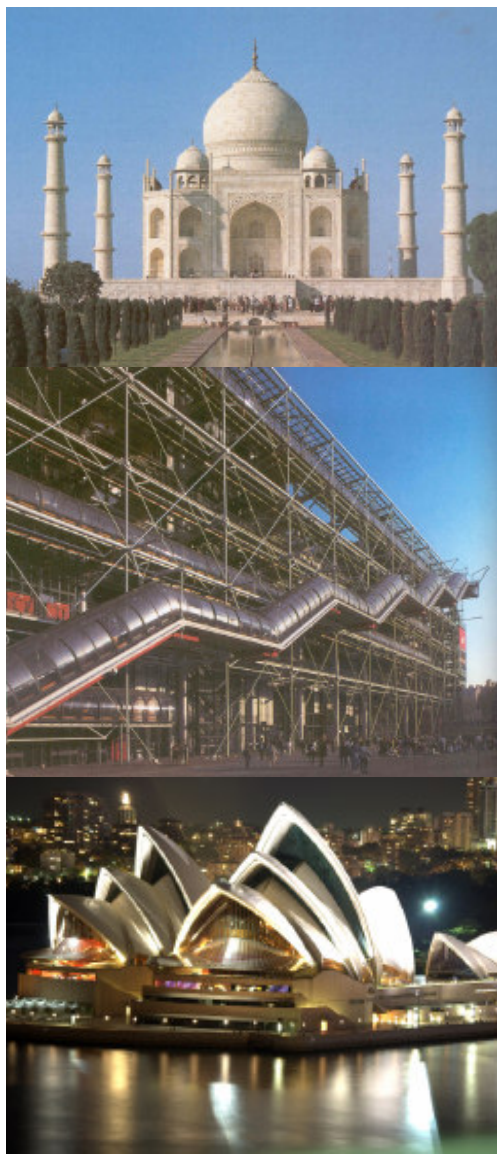

Figs 22, 23 e 24. Taj mahal, Centro Pompidou e Opera House de Sidney. perando seu antecessor, o Taipei 101, com 508 metros. $^{49}$

Ockman e Frausto questionam, então, que diferença haveria entre os papéis representados pelo Taj Mahal, a Torre Eiffel e mesmo construções do século XX, como o Centro Pompidou ou a Opera House de Sydney e as construções contemporâneas que se tornam focos turísticos, representadas pelo pioneiro Guggenheim de Bilbao. Em que sentido a cultura contemporânea teria alterado a relação entre arquitetura e turismo $?^{50}$ Sobre esta questão podemos dizer que a grande diferença recente é a conversão do turismo de conseqüência para causa da arquitetura, concebida desde o início como elemento simbólico representativo do local e marca comercializável, conforme afirmam.

$$
\begin{aligned}
& \text { “(...) a arquiteutra sempre foi parte ingrante da } \\
& \text { experiência turística. Hoje, conforme os luga- } \\
& \text { res são crescentemente reestruturados como } \\
& \text { locais de consumo, e as atividades turísticas } \\
& \text { se fundem com outras práticas de consumo } \\
& \text { em massa, de compras e esportes a cultura e } \\
& \text { educação, a arquitetura está se tornando parte } \\
& \text { integrante da econommia do turismo e vice- } \\
& \text { versa. (...) em uma sociedade de consumo } \\
& \text { avançada, a arquitetura constrói a experiência } \\
& \text { turística e é, em troca, construída por valores } \\
& \text { turísticos.” } 51
\end{aligned}
$$

Apesar de todos os problemas que o seguem, o turismo massificado permitiu que visitássemos locais que jamais sonharam conhecer os que viveram em séculos passados. Schwarzer mostra que locais como a Cidade Proibida, em Pequim, as pirâmides mexicanas e as catedrais européias, além de não serviram ao turismo eram locais de acesso restrito. Usando uma linguagem corriqueira e direta, a revista Viagem e Turismo descreve as reformas realizadas em Zaragoza para que a cidade pudesse sediar a Expo 2008:

"Já se poderia dizer que a prática é tão espanhola quanto bebericar um xerez: uma cidade convoca um (ou vários) arquiteto(s) em alta no mercado - um prêmio Pritzker no currículo sempre vai bem - e ergue em uma zona caidaça uma megaatração com pirotecnias arquitetônicas. Se houver um pretexto para isso, como um evento de projeção internacional, 
52. SETTI, Adriana. Futurismo In. Viagem e Turismo - Especial - Isto é Espanha, edição 151-E 05/2008. São Paulo: Editora Abril p.34. melhor. Foi assim com Barcelona e Sevilha em 1992, quando abrigaram as Olimpíadas e a Expo, respectivamente. Foi assim com a construção do museu Guggenheim de Bilbao, inaugurado em 1997. E está sendo assim com Zaragoza, que entre 14 de junho e 14 de setembro celebrará a Expo 2008, sob a bandeira ecologicamente correta do tema "Água e Desenvolvimento Sustentável". 52

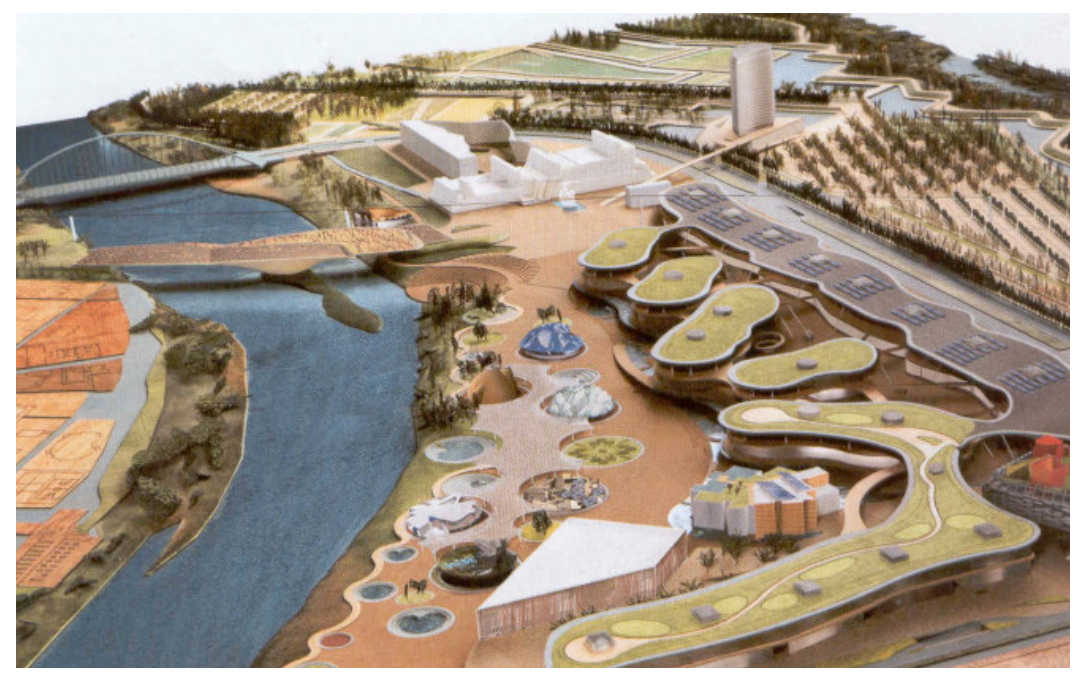

Fig 25. Maquete da área projetada para a Expo 2008, em Zaragoza.

O simples fato de se tratar de uma revista popular de turismo ao invés de um renomado anuário de arquitetura, mostra que já não é novidade, mesmo para o público leigo, que grandes construções de arquitetura espetacular têm sido usadas para promover o turismo em locais antes menos visitados. A reportagem conta que, a partir deste ano, certamente Zaragoza será visitada por muitos curiosos ávidos por conhecer as maravilhas arquitetônicas erguidas para a Expo, assim como Bilbao, após a construção do Guggeheim passou a ser incluída no circuito turístico espanhol, mesmo que seja somente para uma rápida visita ao exterior do museu.

Casos como os de Zaragoza e Bilbao se espalham por todo o mundo. No Brasil pode-se citar o emblemático caso de Niterói, no Estado do Rio de Janeiro, conhecida nacional-

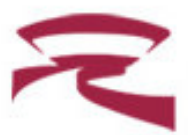

NITERÓ I PREFEITURA

Fig 26. Logo da prefeitura de Niterói. mente após a construção de seu Museu de Arte Contemporânea, projeto de Oscar Niemeyer. O sucesso do edifício levou à expansão do projeto com a criação do Caminho Niemeyer, em um percurso que conta com teatro, estação de barcas, museu e edifícios religiosos, dentre outros. A cidade que antes 
53. www.niteroitv.com.br/guia/ pontosturisticos.asp?pos_menu=\#
54. www.pritzkerprize.com

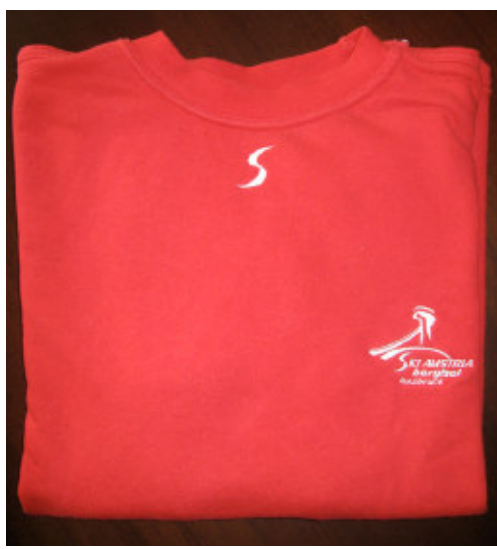

Fig 28. Souvenir de Innsbruck: Bergisel Ski Jump convertido em logo. não possuía qualquer relação com o famoso arquiteto passou a ser divulgada como a cidade dos projetos contemporâneos de Niemeyer, aquela em que, excetuando Brasília, há mais obras do arquiteto no Brasil. ${ }^{53}$

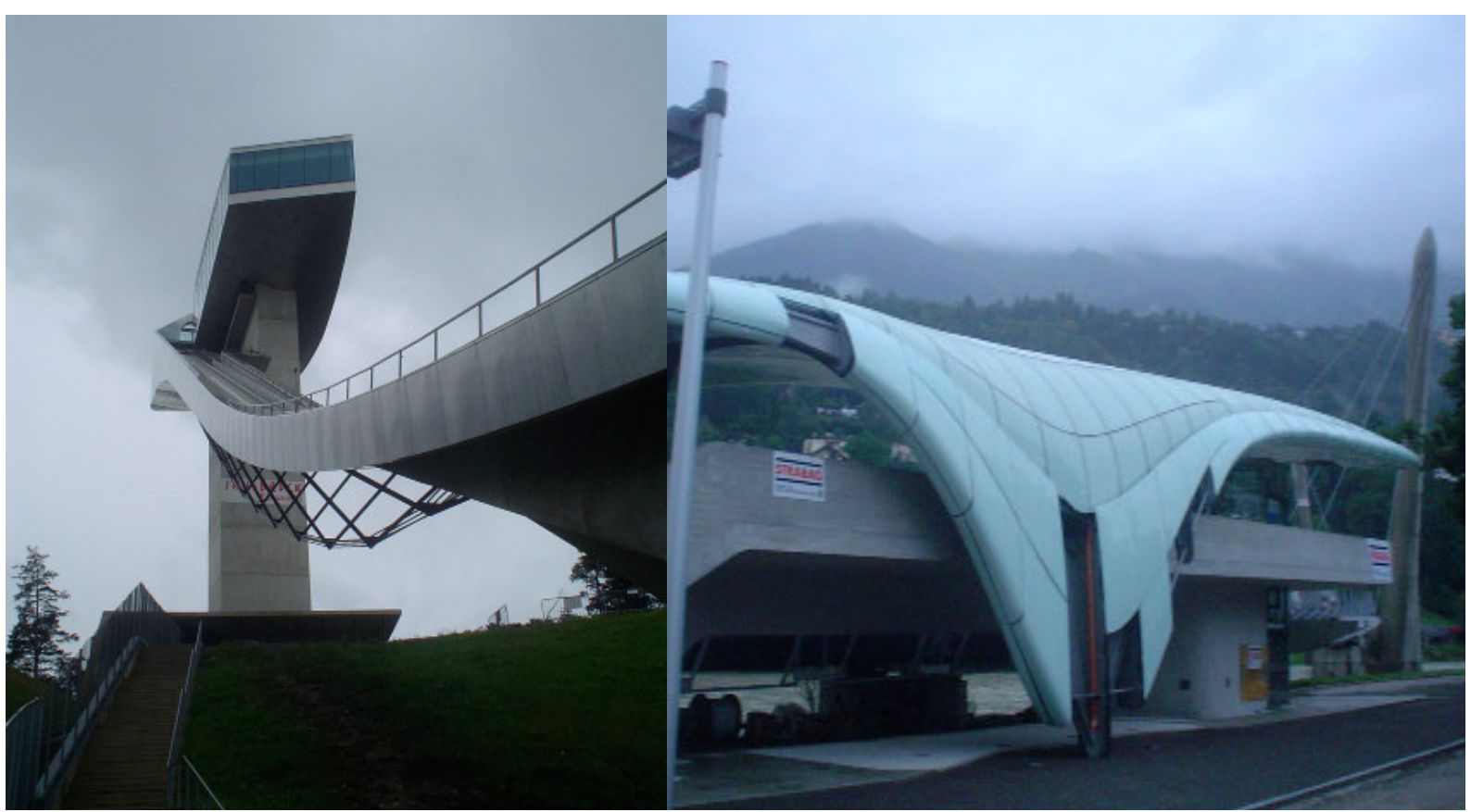

Figs 29 e 30. Bergisel Ski Jump e estação para funicular, em construção. 
55. www.bergisel.info e www. nordpark.com

56. www.zaragoza.es

57. www.innsbruck-tourism.at

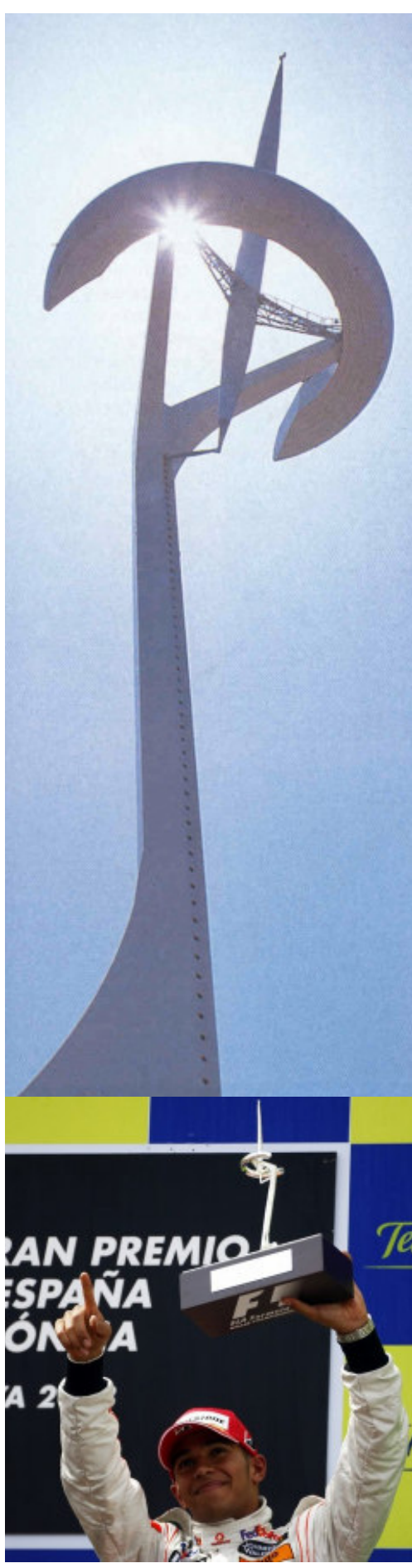

Figs 31 e 32. Torre de Montjüc e Lewis Hamilton, piloto, recebendo o troféu que reproduz a torre.

58. BOTTON (2007) p.68. e teleféricos com estações na cidade e na montanha, todos projetados pela arquiteta. ${ }^{55}$

Zaragoza conta com um centro histórico medieval bem preservado e está exatamente entre Madri e Barcelona. ${ }^{56}$ Innsbruck, além da área central histórica também preservada, é a capital da região do Tirol e sempre foi um grande centro de esportes de inverno ${ }^{57}$. Niterói, mesmo que em escala local, atraía turistas para suas praias, além de estar a poucos minutos do Rio de Janeiro. Assim, percebe-se que mesmo que a cidade já possua atrativos e localização favorável, as novas edificações atraem publicidade, conferindo uma identidade moderna ao local. $\mathrm{Na}$ maioria dos casos a construção torna-se, inclusive, um símbolo da cidade, figurando em logomarcas, sites oficiais, folders e, claro, souvenirs. Enfim, a nova construção torna-se uma espécie de tema explorado à exaustão pela indústria turística local.

Em Barcelona, a Torre de Telecomunicações Montjü̈, projetada por Santiago Calatrava, por ocasião das olimpíadas de 1992, converteu-se em símbolo da modernização da cidade. Sua forma é reproduzida, por exemplo, nos troféus distribuídos ao pilotos campeões do Grande Prêmio de Fórmula 1 da Espanha, realizado na cidade. Segundo Botton, a torre, sob o aspecto funcional, poderia ter qualquer forma e, ainda assim, atender perfeitamente a suas necessidades, mas, como reconheceu Calatrava, "poucos desenhos teriam comunicado com a devida poesia as promessas de modernidade ao povo de Barcelona." 58

Evidentemente, Barcelona já era uma cidade turística, mas associada ao passado, à arquitetura de Gaudí. Tanto a torre de Calatrava, quanto as obras realizadas em função dos Jogos Olímpicos de 1992, trouxeram uma imagem moderna para a cidade. Exemplos semelhantes não faltam, dentre eles a Tate Modern, em Londres, projeto de Herzog e de Meuron, o Disney Concert Hall, de Frank Gehry, em Los Angeles ou a Biblioteca de Seattle, de Rem Koolhaas. Todos atraem visitantes interessados em conhecer sua arquitetura monumental.

Casos como o de Bilbao, ou mesmo Niterói, podem ser contrapostos ao que talvez seja o maior expoente do uso do espetacular em escala urbana - Dubai. Nos últimos anos foi 


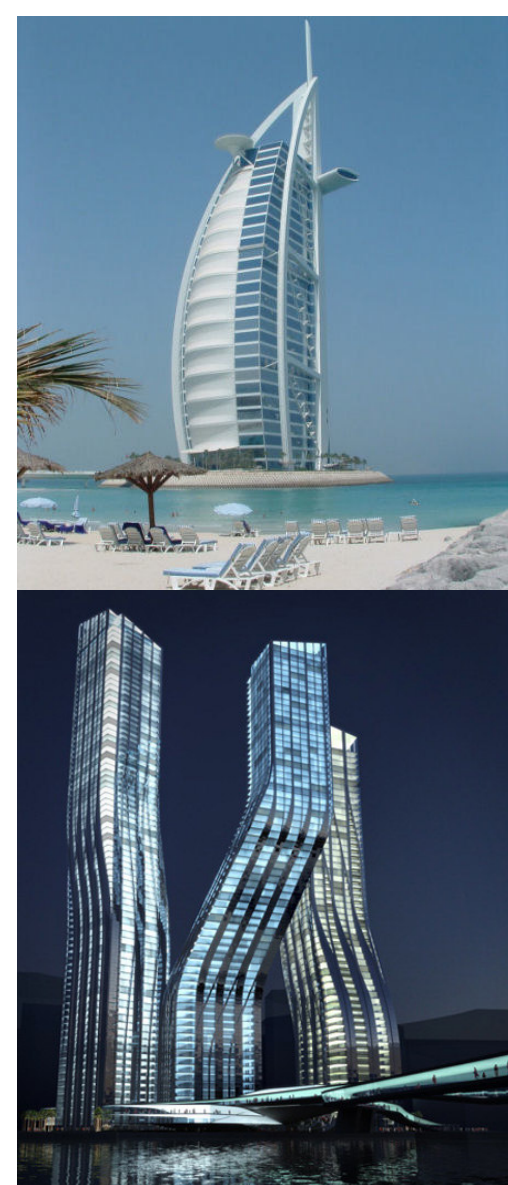

Figs 33 e 34. Burj Al Arab e projeto para Dancing Towers.

59. www.thepalm.ae e www.thewolrd.ae

60. Padrão 7 estrelas. In. Anuário do Turismo Exame. edição 2007/2008.

Editora Abril. Disponível online http://portalexame.abril.com.br/ static/aberto/turismo/anuario_ exame_turismo/m0125855.html

61. www.dubailand.com.ae

62. Dubailand, uma espécie de Disney dos árabes, será duas vezes maior que o parque da Flórida. Jornal O Globo,

Rio de Janeiro: Editora Globo, 05/05/2008 iniciada a construção de dois arquipélagos artificiais ${ }^{59}$, ambos figurativos. O The Palm, cuja ocupação já foi iniciada, visto do alto reproduz palmeiras, enquanto o ousado The World reproduz o mapa-múndi. Dubai conta, ainda, com complexos de lazer como o Ski Dubai, pista artificial de esqui que trouxe neve para o deserto árido. Além disso, os exemplos de construções que seguem o modelo da arquitetura espetacular contemporânea na cidade são incontáveis. Estão em processo o projeto de Rem Koolhaas para o waterfront, as Dancing Towers e a Opera House, de Zaha Hadid, além do já inaugurado hotel Burj Al Arab, apresentado como "o único sete estrelas do mundo". Um dos primeiros edifícios a trazer para Dubai o título de meca da arquitetura contemporânea, o hotel, projetado por Thomas Wright, foi pensado para tornar-se símbolo da cidade, como afirma seu gerente: "O Burj Al Arab está para Dubai assim como a Torre Eiffel está para Paris" ${ }^{\prime 60}$.

Também está em construção no local a Dubailand ${ }^{61}$. Com área de 278 quilômetros quadrados, mais do que o dobro da Disney World, o complexo será composto por parques temáticos, restaurantes, shoppings, hotéis, centros esportivos, como o autódromo de Dubai, já em funcionamento e, inclusive, áreas residenciais. Evidentemente a área contará com um parque inspirado em personagens, nos moldes da Disneyland. Uma parceria com a Marvel Entertainment, detentora dos direitos sobre 'Homem-Aranha', 'Incrível Hulk' e 'X-Men', dentre outros, desenvolverá o primeiro parque temático sobre superheróis. A expectativa é que o complexo esteja completamente inaugurado entre 2015 e 2018, atraindo turistas a ponto de acabar com a dependência local do petróleo. ${ }^{62}$

Assumidamente visando o turismo, Dubai vem construindo edifícios espetaculares, assinados por arquitetos reco-

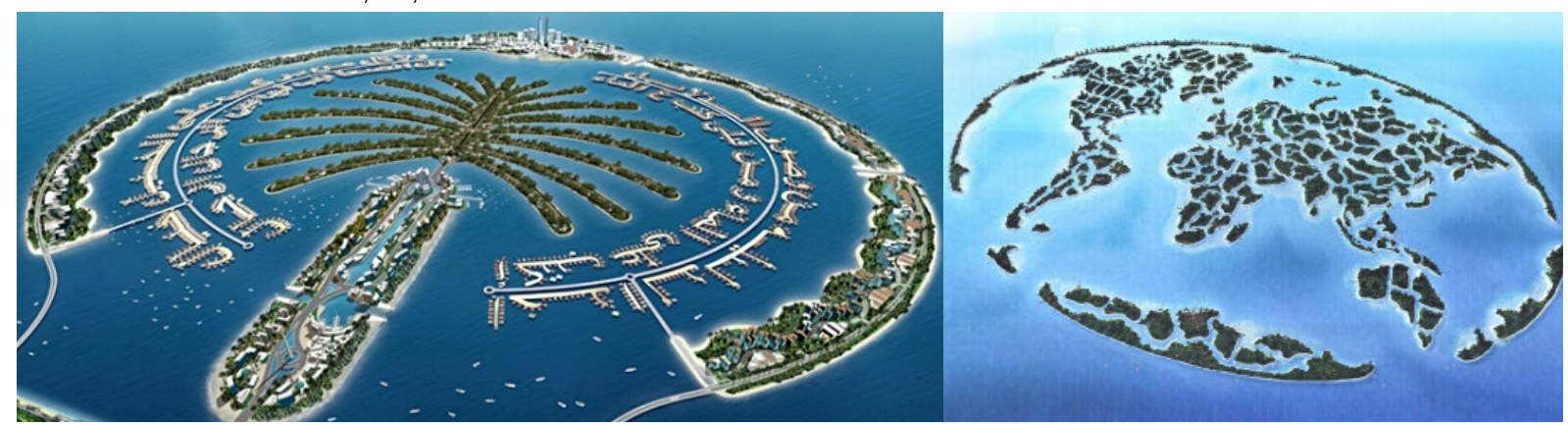

Figs 35 e 36. Simulação tridimensional dos arquipélagos The Palm e The World. 
63. SCHWARZER, Mitchell. Architecture and mass tourism. In. FRAUSTO e OCKMAN (2005) nhecidos em profusão, associando-os a grandes complexos de lazer. Assim, antes um deserto, o emirado, cuja maior parte está ainda em construção, talvez possa mesmo ser identificado mais com as construções monumentais que com algum passado cultural.

Para interessar-se em visitar determinado local é preciso que o visitante tenha previamente alguma referência visual a respeito do que irá conhecer. Para Schwarzer ${ }^{63}$, o reconhecimento substituiu a surpresa enquanto elemento chave do turismo. Por isso, os edifícios construídos recentemente com objetivo de impactar positivamente o turismo do local devem prover imagens fortes, plasticamente interessantes se vistas em postais e, mais ainda, devem despertar interesse quando mostrados em situações dinâmicas, na TV.

Da mesma forma que o reconhecimento valida a visita, o souvenir parece conectar a vida cotidiana à arquitetura monumental, comprovando a visita. Mesmo que a réplica em miniatura da Torre Eiffel ou do Davi de Michellangelo tenha sido comprada no comércio ambulante, o visitante enxerga autenticidade, pois veio de Paris ou Florença. As fotos possuem papel igualmente relevante na validação da viagem, principalmente aos olhos de amigos que parecem ter na fotografia a comprovação da viagem do outro. Talvez por isso seja comum que se busque na fotografia o mesmo enquadramento, a mesma identificação com a imagem prévia do objeto arquitetônico que se busca na visita. A foto também deve remeter à imagem que conhecemos daquele lugar.

Tudo indica que este modelo ainda será explorado por bastante tempo, tanto com a construção de edifícios monumentais, quanto com a exploração de construções modernas antes negligenciadas. Fatalmente, mais cidades industriais com dinheiro e potencial turístico irrisório serão reinventadas pelas formas de Gehry, Hadid, Calatrava, Nouvel. A fundação Guggenheim vem aproveitando o sucesso obtido em Bilbao, seguindo um modelo que praticamente converte o museu em franquia. A fundação disponibiliza obras de sua coleção, exposições itinerantes e consultoria; em contrapartida, a cidade interessada deve responsabilizar-se pela construção e manutenção do museu, além de pagar uma taxa à fundação pelo uso 
64. FRAUSTO e OCKMAN (2005) p.131.

de seu nome. Portanto, o investimento pode não ser tão recompensador, devido ao alto custo. ${ }^{64}$ Recentemente, fracassou a tentativa de inaugurar uma filial no Rio de Janeiro, com projeto de Jean Nouvel, procurando revitalizar a degradada zona portuária da cidade. Após batalha jurídica, ficou estabelecido que seria ilegal o prefeito assinar um contrato com obrigações financeiras que perdurassem após seu mandato.

Portanto, o caráter espetacular da arquitetura temática faz-se presente na arquitetura de hoje, mas não é a única característica herdada do temático. A arquitetura contemporânea rejeita o figurativo, mas está repleta de referências sutis ou nem tanto. O chamado pós-modernismo arquitetônico aliou-se ao temático sob diversos aspectos, mais notadamente por aceitar o figurativo explícito, presente em construções bastante conhecidas, como a Piazza d'Italia, em New Orleans ou o projeto de Frank Gehry para a agência de publicidade Chiat/Day, com a entrada ocupada por um gigantesco binóculo. Para Stern, a Piazza d'Italia, encomendada por um grupo de ítalo-americanos, "evoca tanto os verdadeiros monumentos italianos, como as imagens da Itália que nos trouxeram os fil-

65. STERN. Robert A. M. Novos rumos da moderna arquitetura norteamericana: pós esccrito no limiar do modernismo. In. NESBITT (2006) p.120. mes de Holywood." ${ }^{65}$ Hoje, estes projetos são encarados como anetodas e a apreensão imediata do temático é veementemente negada pela critica especializada, sendo vista praticamente como sub-arquitetura.

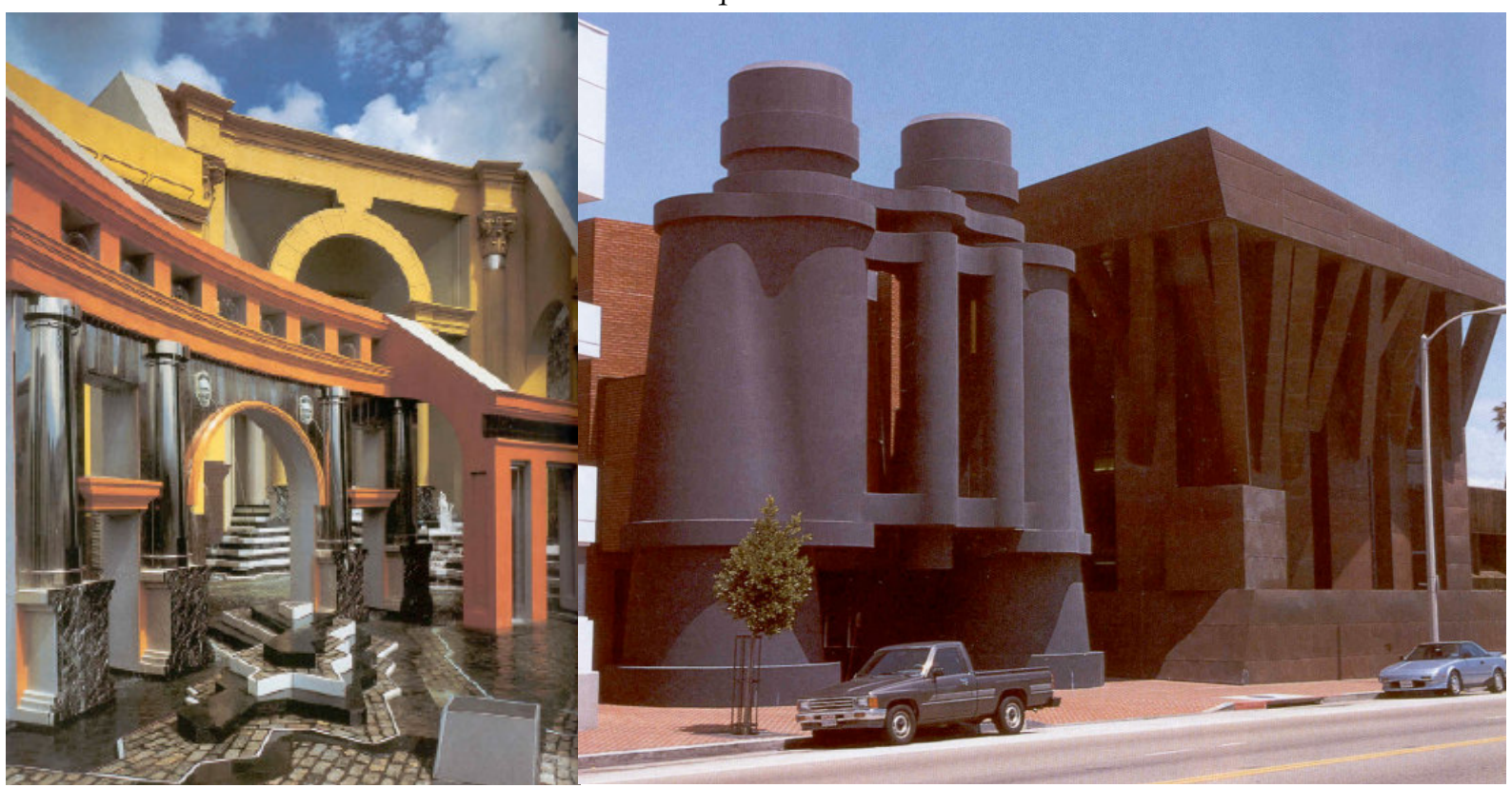

Figs 37 e 38. Piazza d'Italia e Chiat/Day Agency. 
Porém, a produção recente costuma justificar sua concepção em inspirações, em sua maioria, vagamente lembradas na forma final, como a Puente de la mujer, de Santiago Calatrava, em Buenos Aires. O projeto teria sido inspirado no movimento das pernas dos dançarinos de tango. O mesmo ocorre com o já citado Ski Jump de Zaha Hadid, em Innsbruck, inspirado na posição de pernas do esquiador. Entretanto, o olhar corriqueiro do leigo jamais identificaria tais referências se não estivessem descritas em placas de sinalização ou guias turísticos.

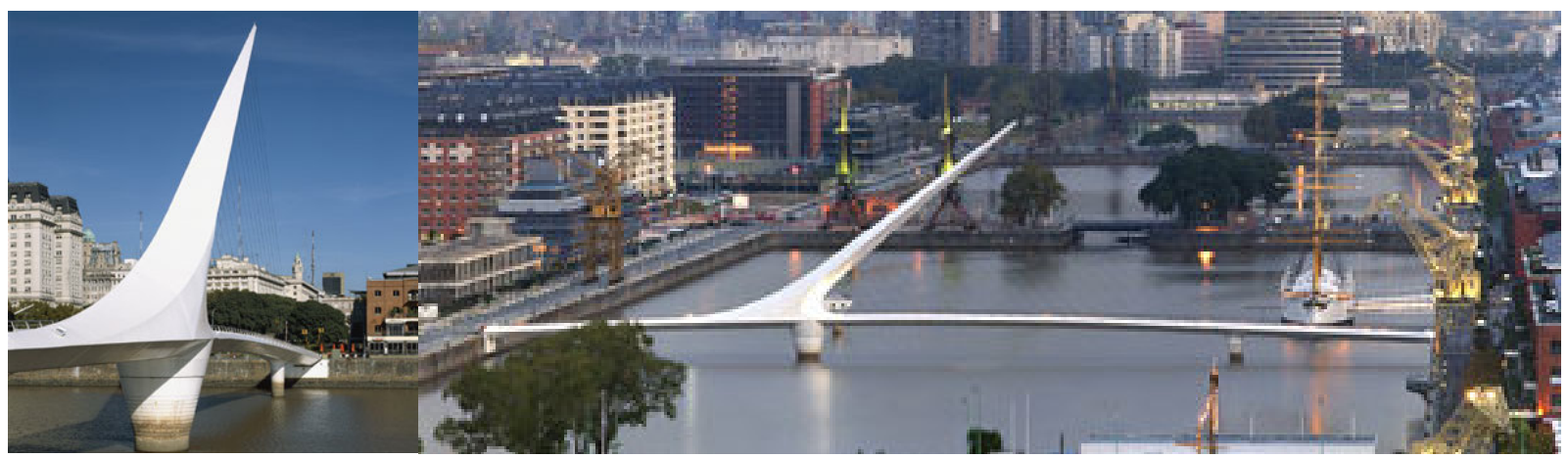

Figs 39 e 40. Puente de la Mujer.

Há edificações em que as referências transparecem claramente. A mesma Zaha Hadid projetou, para a vinícola López de Heredia, um stand para a Barcelona Food Fair de 2002 em que sobressai a forma de um decanter. A construção foi relocada para a sede da vinícola, na região de Rioja, na Espanha, onde funciona como sala de degustação. Outro exemplo, o prédio do Centro de Cultura Judaica, em São Paulo, projeto de Roberto Loeb, é facilmente percebido como uma representação da Torá, o livro sagrado das escrituras judaicas. Na Austrália, o Hotel Holyday Inn Resort Gagudju Crocodile, localizado no

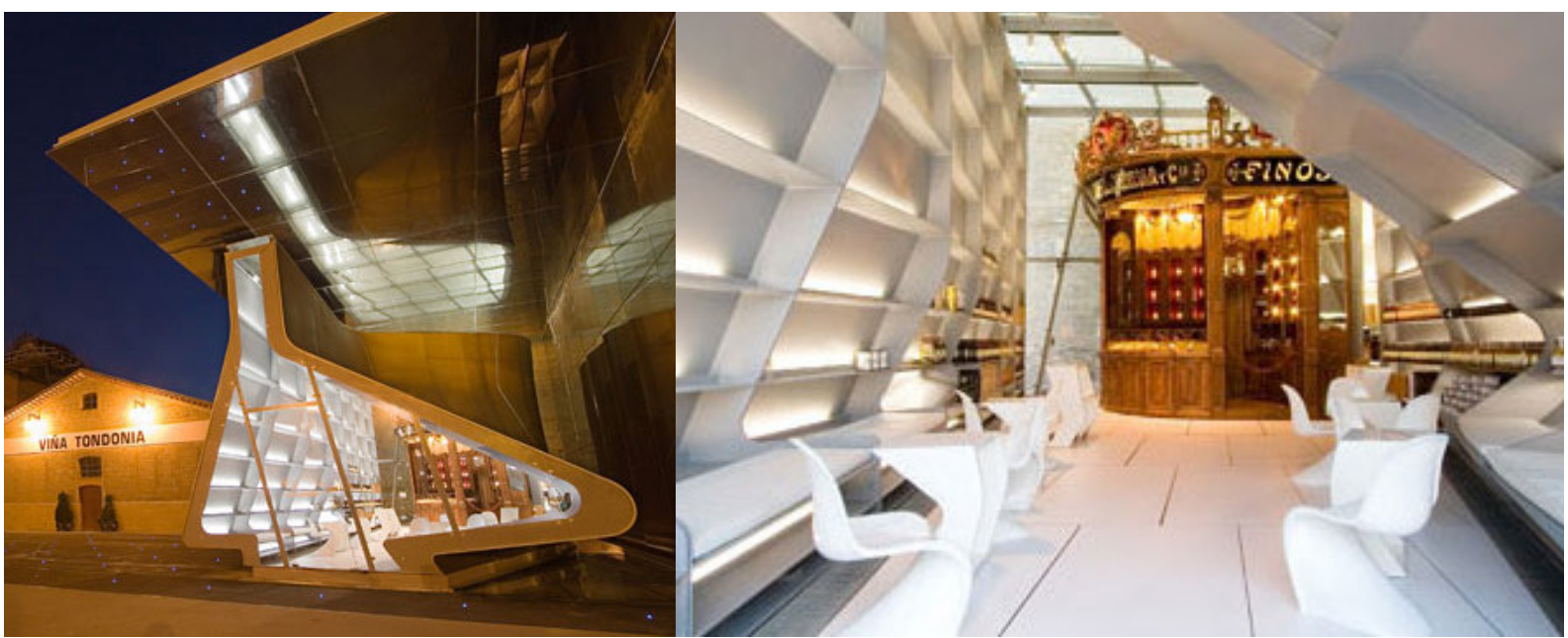

Figs 41 e 42. Sala de degustação da Vinícola López de Heredia. 
Parque Nacional de Kakadu, possui o formato de um crocodilo. Menos óbvio que o pato de Venturi, o hotel apresenta uma forma mais abstrata, só percebida em sua totalidade se vista do alto, mas, ainda assim, trata-se de representação figurativa.

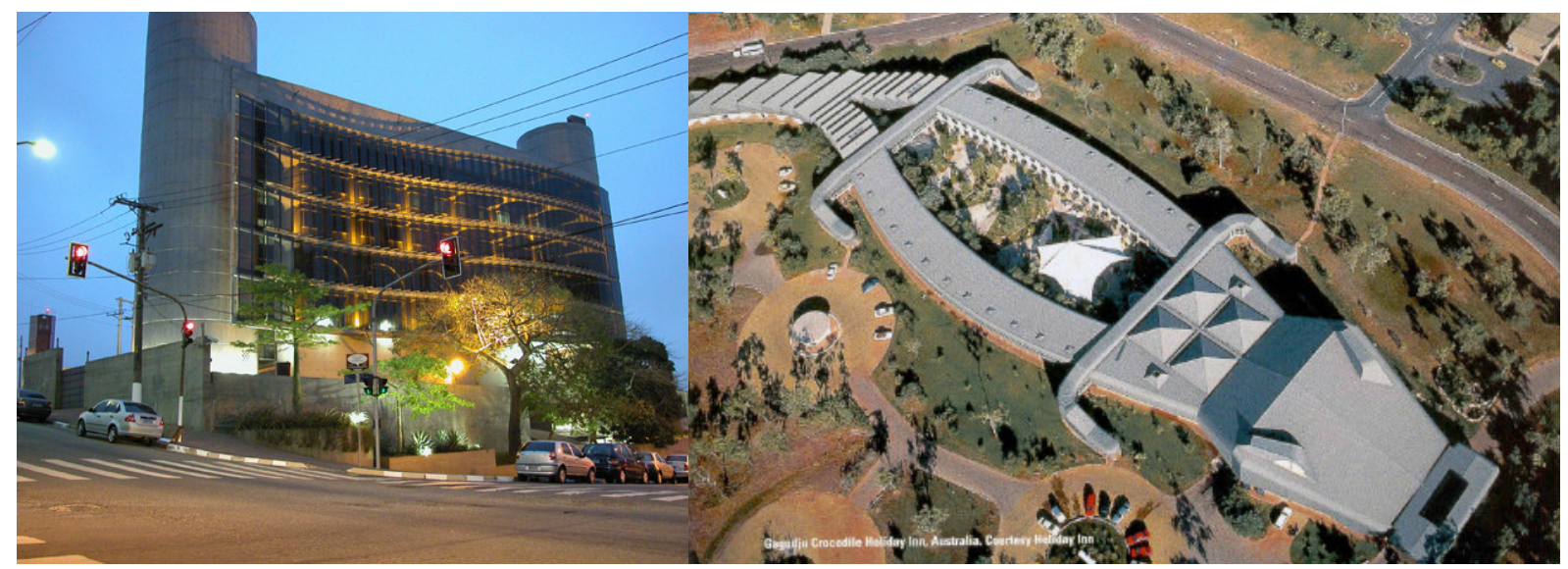

Figs 43 e 44. Centro de Cultura Judaica, em São Paulo e Hotel Holyday Inn Resort Gagudju Crocodile.

Tanto no caso das referências imperceptíveis quanto nos casos em que o figurativo transparece, a forma adotada remete ao programa, facilitando sua compreensão e divulgação. Se não há o conceito de identificar o tema em toda e qualquer forma presente no projeto como no temático, certamente há a presença discreta, ou nem tanto, do figurativo. Dando seqüência às discussões sobre o ornamento na arquitetura, o uso do figurativo como recurso expressivo vem sendo questionado por teóricos da arquitetura nos últimos anos.

Eisenman afirma que o modernismo nunca existiu e, portanto, não existe o pós-moderno. Para ele, se houve em outras áreas uma transição do pensamento humanista para o modernista, na arquitetura manteve-se a mesma atitude nos últimos quinhentos anos. Seu raciocínio baseia-se na idéia de que, desde o Renascimento, seguimos uma continuidade fundamentada na relação entre forma e função, e todas as supostas mudanças a que assistimos, incluindo os chamados estilos modernista e funcionalista, não passariam de deformações desta dualidade. A proposta de Eisenman, o pós-funcionalismo, preconiza a evolução da própria forma, condenando o

66. EISENMAN, Peter. O pósfuncionalismo. In. NESBIT'T (2006) pp. $95-101$ figurativo. ${ }^{66}$

Se Eisenman aspira a uma arquitetura autônoma, Michael Graves defende o uso de simbolismos, inclusive através do figurativo, como resposta cultural. Para ele, há questões 
67. GRAVES, Michael. Argumentos em favor de uma arquitetura figurativa. In. NESBITT (2006) p.102.

68. Ver Capítulo 1.5

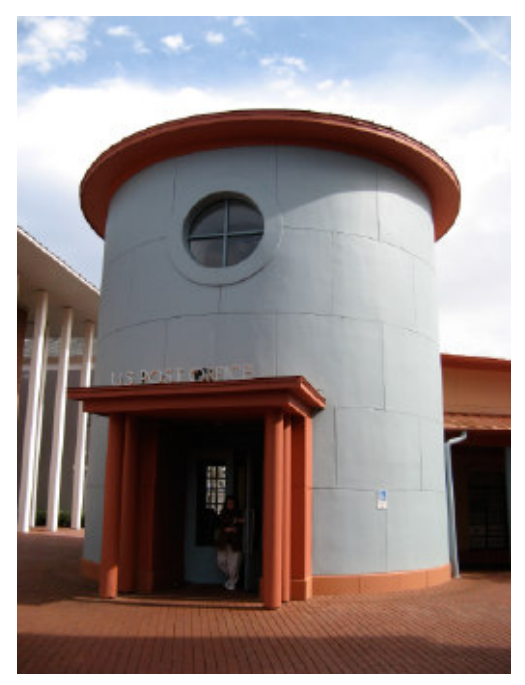

Fig 45. Agência dos correios em Celebration, projeto de Michael Graves.

69. Ver Capítulo 1.3

70. PORPHYRIOS, Demetri. $A$ pertinência da arquitetura clássica. In. NESBITT (2006) p.112. técnicas (práticas), resolvidas estruturalmente, do ponto de vista utilitário, e questões culturais (poéticas), resolvidas através do figurativo que evoca associações. Graves descreve assim sua visão sobre o projeto:

"Eu procuro projetar usando uma paleta ampla, refraseando a linguagem tradicional da arquitetura e suas formas reconhecíveis e, ao mesmo tempo, recorrendo às lições da composição moderna, sempre de modo a responder ao programa, ao local e aos desejos do cliente. Minha arquitetura vê com novos olhos tanto o classicismo como o modernismo, pois ambos contêm alusões que fazem parte de nossa cultura contemporânea. ${ }^{{ }^{67}}$

Nesbitt afirma que "Por sua forte qualidade imagética, a obra de Graves é suscetível à apropriação e manipulação por parte de construtores e outros agentes que empacotam o abrigo como mercadoria." Esta afirmação parece supor, ingenuamente, que o arquiteto é enganado, tendo o significado de sua obra corrompido. Ao contrario, parece que Graves não vê qualquer problema em vender sua obra, mesmo porque é um dos pioneiros dentre os arquitetos consagrados a aceitar a proposta de projetar para Disney ${ }^{68}$.

Porphyrios pensa que o ecletismo visto no pós-moderno retomou repertórios do passado como veículos de comunicação, criando situações em que não havia qualquer relação entre a construção e os valores relacionados ao período retomado. Além disso, as obras evidenciariam um artificialismo, fazendo-nos ver que tudo é artificial e, portanto, incorrendo na paródia. A esta crítica é associada a crítica à construção pós-moderna como cenografia, fazendo referência ao "galpão decorado" de Venturi ${ }^{69}$. Assim, afirma que: "Perante a arquitetura pós-moderna temos a impressão de que, de algum modo, todos os valores foram analisados e rejeitados e que a adesão a esta ou aquela opinião não passa de uma brincadeira". ${ }^{70}$

Ainda que não seja esta a intenção dos arquitetos chamados pós-modernistas, a alusão de Porphyrios à brincadeira é bastante coerente com o momento atual. Talvez a diferença, seja o fato de mencioná-la como crítica, enquanto hoje a brincadeira está perfeitamente assumida, sem grandes constrangi- 
71. STERN. Robert A. M. Novos rumos da moderna arquitetura norteamericana: pós escrito no limiar do modernismo. In. NESBITT (2006) p.120. mentos, senão no campo da arquitetura, com certeza na vida cotidiana, na comunicação.

Robert Stern alinha-se aos que defendem a arquitetura como sistema de signos. Se hoje, a maioria das análises sobre o historicismo pós-moderno discorre sobre a fantasia embutida em suas formas, Stern, em artigo publicado pouco após "Learning from Las Vegas", vê nestas formas "realismo". A visão de Stern decorre de sua percepção de que o historicismo pósmoderno relaciona-se com seu meio sócio-cultural e político.

"Essa pesquisa pós-modernista do precedente histórico nasceu da convicção de que fazer referências adequadas à arquitetura histórica pode enriquecer os novos projetos e, com isso, torná-los mais acessíveis, familiares e possivelmente ainda mais significativos aos olhos das pessoas que usam os edifícios. Trata-se, em uma palavra, de um sistema de pistas que ajuda a melhorar a comunicação entre arquitetos e usuários a respeito de suas intenções." ${ }^{71}$

Corroborando esta visão, identifica, além do alusionismo destacado por Venturi, dois princípios que nortearam a produção, especialmente de Venturi e Moore, considerados pioneiros do pós-modernismo.

O primeiro, o contextualismo, refere-se à pertinência do edifício pós-moderno em relação ao entorno. A edificação é uma parte de um todo maior, o espaço urbano. O segundo princípio, ornamentalismo, defende que há uma necessidade humana de volumetria tridimensional nas paredes, mesmo que esta volumetria não venha de referências históricas. Ressalta a relevância da fachada enquanto significado arquitetônico, citando exemplos de edificações de Venturi em que há tratamento tridimensional geométrico.

Tschumi critica os historicistas pós-modernos, qualificados como "falsa polêmica". Para ele tanto esta tendência, quanto o que chama neomodernismo, de Eisenman, voltamse exclusivamente para o formalismo, excluindo preocupações sociais. Sua solução seria pensar a arquitetura como uma interação do espaço com os eventos, o programa funcional seria substituído pelo programa relacionado a um espetáculo ou evento. Tschumi defende que a forma continua seguindo a 
72. TSCHUMI, Bernard. Arquiteutra e Limites III. In. NESBIT'T (2006) pp.183-188.

74. TSCHUMI, Bernard. Introducão: notas para uma teoria da disjunção arquitetônica. In. NESBITT (2006) p.188. forma, a prática provou que a conversão funcional de edifícios é totalmente possível. Entretanto, o pensamento funcional deve girar em torno da relação estabelecida entre o homem, o corpo, os eventos que ocorrerão e o espaço. ${ }^{72}$

O projeto de Tschumi para o Parc La Villette, nos arredores de Paris, ilustra esta preocupação. As folies podem ser apropriadas pelo usuários para funções diversas. No entanto, convivem com o figurativo lúdico do parque infantil em que crianças brincam com a escultura que representa uma gigantesca bicicleta enterrada no chão. Da mesma forma, ainda que rejeite a visão historicista e figurativa, Tschumi parece alinhar-se ao modelo contemporâneo da arquitetura espetacular. Evidentemente, não se trata de um parque temático, mas sua arquitetura tem enfoque turístico e suas formas podem facilmente converter-se em marca do local. Além disso, os projetos de Tschumi demonstram seu apreço pelas técnicas de 73. Ver Capítulo 1.5. colagem, também bastante utilizadas no temático ${ }^{73}$ :

"Ele [Tschumi] importa do cinema técnicas de edição como a "dissolução"e "montagem", de modo a desafiar as representações gráficas convencionais. Devido à sua duração temporal, o cinema oferece possibilidades para a narrativa e revela inusitadas relações entre o evento e o espaço." 74

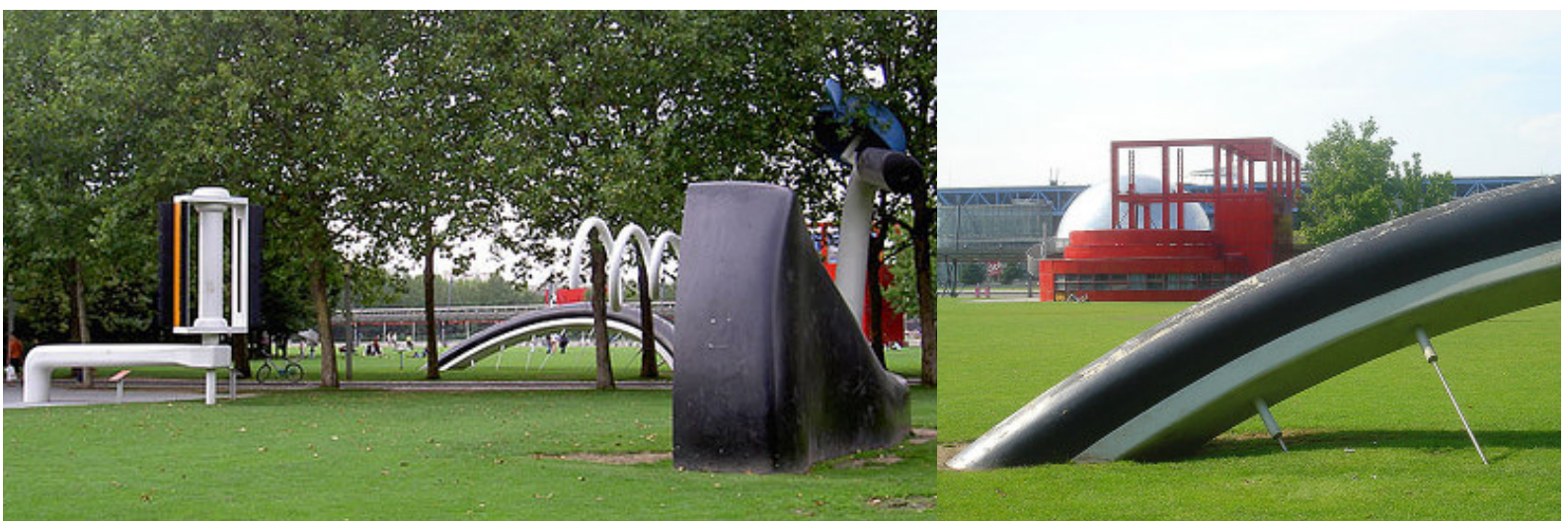

Figs 46 e 47. Escultura de Claes Oldenburg no Parc de La Villette. Ao fundo, Folie de Tschumi.

É evidente que, ao citar os exemplos de Tschumi, Gehry, Hadid e outros, já não tratamos de arquiteturas temáticas, mas, seja através do espetáculo, do uso do figurativo ou das técnicas de colagem, a arquitetura de hoje se relaciona ao temático. Sob os aspectos citados, podemos entender estas construções contemporâneas como desdobramentos do 
temático, em que persistem a preocupação com o lazer e o lúdico visando atrair o visitante, aliados ao interesse comercial. Entretanto, se no modelo temático nem chegamos a avaliar a qualidade da arquitetura, no modelo espetacular contemporâneo, sem o figurativo tão direto e despidos de preconceito, nos atemos com mais cuidado.

75. Ver Capítulo 1.5

Quando Foster fala do modelo atual de design total ${ }^{75}$, podemos associar ao modelo a exploração da arquitetura espetacular na cidade. A arquitetura monumental é utilizada para dotar a região de alguma subjetividade, tornando-se seu principal signo. Assim, se a arquitetura em si não é temática, sua imagem é explorada em souvenirs e propagandas, de forma alegórica. Em analogia ao temático, em que o tema deve ser percebido em todo e qualquer detalhe, a construção torna-se onipresente na cidade que a abriga. 


\section{Conclusão}

Vimos que o uso de alegorias ou estilos como elementos construtores de identidade no espaço urbano precede em muito os parques temáticos, remetendo às primeiras civilizações, quando efeitos especiais ou o estilo arquitetônico uniforme eram representativos, convincentes, acerca do poder do governante. Os parques temáticos parecem ter levado esta exploração às últimas conseqüências, com a introdução do tema como elemento caracterizador do espaço e o uso de alegorias e narrativa de apreensão imediata como instrumento para transmitir esta identidade. Vimos, também, que o uso de temas extrapolou as barreiras dos parques, sendo levado a estabelecimentos comerciais. Se lojas e espaços de lazer adotaram o temático para atrair clientes, logo cidades se aliaram ao modelo para atrair o visitante.

Neste sentido, chegamos a identificar diferentes casos em que reestruturações urbanas foram baseadas na retomada de supostas tradições locais, também com o propósito de consolidar identidades. De reconstruções alegóricas ao New Urbanism, passando por cidades relocadas ou inteiramente construídas, a idéia de retomar características históricas já foi posta em prática nas mais diversas situações, muitas vezes gerando polêmica. Portanto, mesmo preservações históricas, ainda que não figurativas, são, sob certo aspecto, temáticas, a partir do momento em que adotam como tema determinado recorte temporal.

Deve-se avaliar até que ponto a população realmente almeja a manutenção ou retomada destas características, ou já se identifica com novas referências. Além disso, houve casos em que as referências buscadas não condiziam com a realidade da história local, e há quem veja estas citações ao passado como algo exclusivamente cenográfico. Afinal, é preciso pensar em como é feita a identificação das características a serem retomadas.

Assim, seja para valorizar um local ou um comércio, o tema vem sendo apropriado pelo espaço, como instrumento publicitário. No entanto, concluímos que o uso da arquitetura 
1. BOTTON (2007) p.145.

2. FRAUSTO e OCKMAN (2005) p.125.

"If we are too formally or ideologically detached from the ways the tourists use theme parks and malls and the like, we miss the point. One of the things I've always noticed at the Mall of America and the Disney venues is the smiling faces. These smiles are not on the faces of ignorant dopes consuming architecture (or baked goods) like so any rats in a maze. They're walking and looking with real pleasure at things - façades, simulations, wishes captured in brick and mortar (or fiber glass) - that they would otherwise not have a chance to see. Tourists are being displaced from their ordinary realities. And they're happy." como propaganda não implica, necessariamente, uma perversão de seu significado original, conforme mostra Botton:

“(...) o termo "propaganda" refere-se à promoção de qualquer doutrina ou conjunto de crenças e, por si só, não tem nenhuma conotação negativa. (...) Uma obra de arte passa a ser uma peça de propaganda quando utiliza os seus recursos para nos direcionar para alguma coisa, na medida em que tenta intensificar a nossa sensibilidade e a nossa prontidão para reagirmos de forma favorável a um fim ou idéia."1

A arquitetura, como a arte, sempre fez propaganda de idéias. Ao longo do tempo fez propaganda de governos e, com o temático, passou a anunciar lazer e experiências comercializáveis. Agora, a arquitetura espetacular se coloca a serviço do marketing de lugar.

De fato, a faceta turística da arquitetura contemporânea parece a mais coerente com nosso tempo. Sobre a pertinência do temático em nossa sociedade e a critica de que a imersão nesta fantasia seria alienante, percebemos, que, ao contrário do que se poderia pensar, o visitante de Espaços Temáticos parece bastante consciente:

\footnotetext{
"Se estamos formalmente ou ideologicamente muito desvinculados das maneiras como os turistas usam parques temáticos, shoppings e afins, perdemos o foco. Uma das coisas que sempre notei no Mall of America e em espaços da Disney foram os rostos sorridentes. Esses sorrisos não estampam os rostos de ignorantes entorpecidos consumindo arquitetura (ou outras coisas) como ratos em labirinto. Eles estão andando e olhando com prazer real as coisas - fachadas, simulações, desejos capturados em tijolo e argamassa (ou fibra de vidro) que de outra forma não teriam chance de ver. Os turistas estão sendo deslocados de suas realidades cotidianas. E estão felizes."2
}

Contudo, não se propôs aqui o pastiche generalizado. A tendência em trabalhar o design de interiores residenciais através de alegorias temáticas, por exemplo, parece bastante reducionista em relação à personalidade do habitante. Certamente, o adolescente que pede um quarto com tema basquete, 


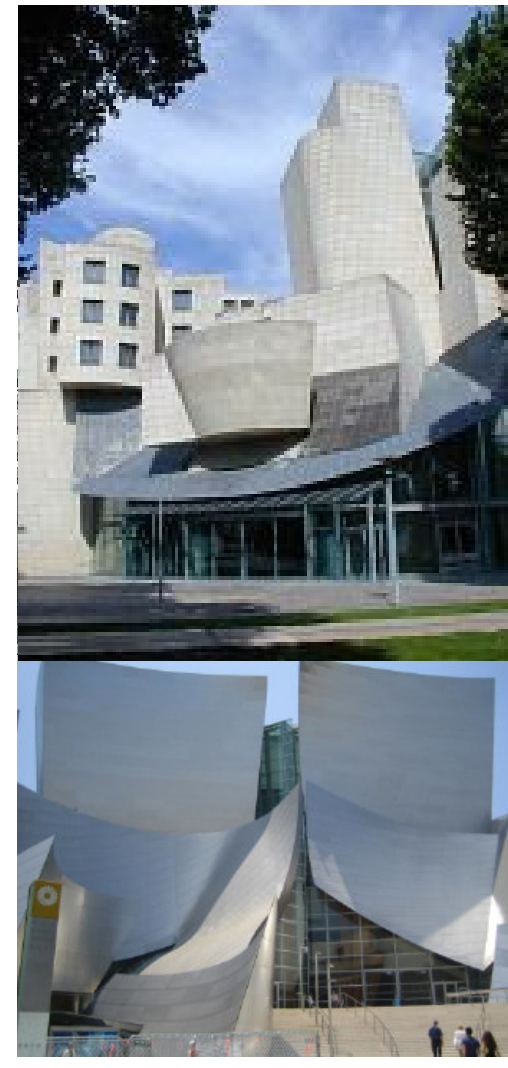

Figs 1 e 2. American Center e Disney Concert hall. ou futebol, não é e não será apenas uma pessoa que gosta de esportes. Por outro lado, uma loja temática é exatamente isso, uma loja temática. Além disso, vimos que o temático tem um prazo de validade e, enquanto espaços comerciais podem ser remodelados com freqüência, o espaço residencial requer uma durabilidade maior.

Assim, parece que o temático, comumente pontuado com a construção dos parques, faz parte de um processo contínuo de construção identitária através da arquitetura, como atrativo, tanto para o morador local, quanto para o visitante, seja com fins comerciais e/ou políticos. Recentemente, a demanda por autenticidade vem restringindo o temático a parques e estabelecimentos especificamente voltados para o lazer. Nestes locais, o tema é tido como mais coerente que em outros, cujo programa não condiz com o lúdico. Portanto, a valorização da percepção de autenticidade fatalmente levará ao uso da arquitetura espetacular, em detrimento ao temático, especialmente no que diz respeito à sua exploração urbana. Vimos que, se a arquitetura contemporânea nega o modelo temático, ao mesmo tempo alia-se a este sob diversos aspectos.

Conclui-se que a questão já é não pôr em cheque a pertinência do temático, mas tentar avaliar que conseqüências terão seus desdobramentos mais recentes. Podemos identificar, então, pontos que deverão ser abordadas futuramente, de acordo com possíveis rumos desta arquitetura espetacular. Se o grande atrativo turístico hoje são construções de caráter espetacular em que sobressai a assinatura do arquiteto, parece que o próximo passo é questionar o que irá acontecer quando estas construções, de tão freqüentes, já não causarem admiração, ou se haverá sempre uma nova idéia, uma nova tecnologia, que atraia público enquanto este modelo for coerente com nossa situação econômica e cultural.

Podemos levantar, ainda, a hipótese de que, se há uma constância na assinatura do arquiteto, pode haver em algum momento um esgotamento do elemento surpresa em sua obra. Esta discussão vem ganhado espaço em função do chamado “efeito Bilbao". A composição formal de Gehry, em Bilbao, remete, sem dúvida, ao Disney Hall (2003), em Los Angeles, e ao American Center (1994), em Bercy. Se a marca de Gehry 
continuar se espalhando, é possível que, futuramente, pensemos se é justificável a ida a Bilbao somente em função do Guggenheim, quando existem obras bastante semelhantes a poucos quilômetros de casa. A outra possibilidade é que a cidade, apoiada no fluxo que se dirige a Bilbao, desenvolva um conjunto de atrativos turísticos e infra-estrutura de apoio consistentes, tornando-se definitivamente um destino turístico. Caso isso não ocorra, a pergunta será a respeito do envelhecimento e preservação do edifício. Neste caso, é possível que se abandone temporariamente o fluxo em direção à cidade, mas que ele seja retomado anos mais tarde quando o edifício passar de maravilha moderna a marco histórico.

Vimos, também, que inúmeras cidades ditas históricas tiveram toda sua arquitetura orientada a salientar este caráter. Certamente, a relação do entorno, da cidade, com a arquitetura monumental contemporânea será uma questão a ser discutida em breve. Ainda que estejamos vivenciando uma valorização do original, é bastante provável que tenhamos que conviver com réplicas genéricas. Seguindo o processo em que a arquitetura espetacular se torna onipresente na cidade, através de menções em logomarcas e souvenirs, é possível que passe a ser citada em outras arquiteturas próximas, procurando remeter ao "símbolo da cidade".

O temático deve ser visto, então, como parte de um processo em curso. Se há um movimento de retorno a produções ditas autênticas, abandonando o fake assumido, a espetacularização, o uso de referencial figurativo e a colagem recontextualizada de elementos, característicos do modelo temático, estão presentes na arquitetura de hoje, contribuindo para determinar como percebemos o espaço urbano. 


\section{Bibliografia}

A Herança do pai da turma da Mônica. In. Revista Exame edição 0851 Editora Abril. Disponível em http://portalexame.abril.com.br/revista/exame/ edicoes/0851/negocios/m0057371.html

ADEMBRI, Benedetta. Hadrian's Villa. Milano: Electa, 2005.

ANDRADE, Flavia. Design, cenografia e entretenimento: uma análise da evolução dos Espaços Temáticos e suas principais implicações. 2004. Dissertação (Mestrado em Design) Departamento de Artes e Design - Pontifícia Universidade Católica do Rio de Janeiro.

ANHOLT, Simon. Brand New Justice How branding places and products can help the developing world. Revised Edition. Burlington: Elsevier Butterworth-Heinemann, 2005.

ARGAN, Giulio Carlo. Arte Moderna. São Paulo: Companhia das Letras, 2002.

- Clássico Anticlássico O Renascimento de Brunelleschi a Bruegel. São Paulo: Companhia das Letras, 1999.

ARIÈS, Phillipe. História social da criança e da família. 2a. Edição. Rio de janeiro: LTC, 1981.

AROCHI, Luis E. La pirâmide de Kukulcán: su simbolismo solar. Octava reimpresión corregida y actualizada. Anzures: Panorama Editorial, 1992.

ASHWORTH, Gregory J. e VOOGD, Henk. Marketing and place promotion. In. GOLD, John R. e WARD, Stephen V. (org.). Place Promotion The use of publicity and marketing to sell towns and regions. Chichester: John Wiley and Sons, 1994.

BAUMAN, Zygmunt. Identidade: Entrevista a Benedetto Vecchi. Rio de Janeiro: Jorge Zahar Editor, 2005.

. Modernidade Liquida. Rio de Janeiro: Jorge Zahar Editor, 2001.

Vida para consumo: a transformação das pessoas em mercadorias. Rio de Janeiro: Jorge Zahar Editor, 2008.

BLECHER, Nelson e MARTINS, J.R. O Império das Marcas. São Paulo: Marcos Cobra Editora, 1996.

BONEQUINHAS de luxo. Revista Marie Claire. Rio de Janeiro: Ed Globo, 2004. Edição 157. pp.115-118.

BOTTON, Alain de. Arquitetura da Felicidade. São Paulo: Editora Rocco, 2007.

O Desejo de Status. São Paulo: Editora Rocco, 2004.

BOURDIEU, Pierre. A Economia das Trocas Simbólicas. São Paulo: Editora Perspectiva, 2001.

BRUAND, Yves. Arquitetura Contemporânea no Brasil. São Paulo: Editora Perspectiva, 2002.

BUENO, Francisco da Silveira. Dicionário Escolar da língua portuguesa 11a. edição. Rio de Janeiro: FAE, 1984.

BURKE, Peter. A Fabricação do Rei: A Construção da Imagem Pública de Luís XIV. Rio de Janeiro: Jorge Zahar Editor, 1994.

CARLOS, Ana Fani Alessandri. O turismo e a produção do não-lugar. In YÁZIGI, Eduardo, CARLOS, Ana Fani Alesandri e CRUZ, Rita de Cássia da (org). Turismo: Espaço, Paisagem e Cultura. São Paulo: Editora HUCITEC, 1996. 
CASTROGIOVANNI, Antonio Carlos e GASTAL, Suzana (org). Turismo Urbano: Cidades, sites de excitação turística. Porto Alegre: Edição dos autores, 1999.

CHOAY, Françoise. A Alegoria do patrimônio. São Paulo: Editora Unesp, 2001.

COLQUHOUN, Alan. Modernidade e Tradição Clássica - ensaios sobre arquitetura 1980-87. São Paulo: Cosac \& Naify, 2004.

CUNHA, L. Economia e Política do Turismo. Lisboa: McGraw Hill, 1997.

DORFLES, Gillo. Introdução ao Desenho Industrial. Lisboa: Edições 70, 1972.

DUBAILAND, uma espécie de Disney dos árabes, será duas vezes maior que o parque da Flórida. Jornal O Globo, Rio de Janeiro: Editora Globo, 05/05/2008.

DUNLOP, Beth. Building a Dream - The Art of Disney Architecture. New York: Harry N. Abrams Publisher, 1996.

ECO, Umberto. Travels in hyper reality: essays. New York: Harcourt, 1986.

FERREIRA, Aurélio Buarque de Hollanda. Novo Aurélio século XXI: o dicionário da lingual portuguesa 3 a. edição. Rio de Janeiro: Nova Fronteira,1999.

FJELLMAN, Stephen M. Vinyl Leaves - Walt Disney World and America. Boulder: Westview Press, 1992.

FOSTER, Hal. Design and Crime (and other diatribes). Verso. London: 2003.

FRAMPTON. Kenneth. História Crítica da Arquitetura Moderna. Martins Fontes. São Paulo:2003.

FRAUSTO, Salomon. OCKMAN, Joan. (org.). Architourism Authentic Escapist Exotic Spectacular. Prestel. New York: 2005.

GIACOMINI FILHO, Gino. Colecionismo na Comunicação Mercadológica. In CORRÊA, Tupã Gomes e FREITAS, Sidnéia Gomes (org.) Comunicação, Marketing, Cultura: sentidos da administração, do trabalbo e do consumo. São Paulo: ECA/USP, 1999.

GILMORE, James H. e PINE II, B. Joseph. Autenticidade: tudo que os consumidores realmente querem. Rio de Janeiro: Elsevier, 2008.

GOLD, John R. e WARD, Stephen V. (org.). Place Promotion The use of publicity and marketing to sell towns and regions. Chichester: John Wiley and Sons, 1994.

GORMAN, Carma R. (edit.). The Industrial Design Reader. New York: Allworth Press, 2004.

GYMPEL, Jan. Histoire de l'Architecture. De l'Antiquité a nos Jours. Köln: Könemann, 1997.

HARVEY, David. Condição Pós-Moderna - Uma Pesquisa sobre as Origens da Mudança Cultural. São Paulo: Edições Loyola, 1999.

HAUSER, Arnold. História Social da Arte e da Literatura. São Paulo: Martins Fontes, 2000.

HOBSBAWN, Eric J. A Invenção das Tradições. Rio de Janeiro: Paz e Terra, 2000.

HUXLEY, Aldous. Admirável mundo novo. 2a. Edição. São Paulo: Editora Globo, 2001.

HUXTABLE, Ada Louise. The Unreal América Architeture and Illusion. The New Press. New York:1993.

JACOBS, Jane. Muerte y Vida de las Grandes Ciudades. Madrid: Ediciones Península, 1973. $2^{\text {a }}$ ed. 
JANUZZI, Melissa. Um passeio pela história - Espetáculo de som e luz, no Museu de Petrópolis. In. Revista Veja Rio. São Paulo: Editora Abril, Ano 35. $\mathrm{N}^{\mathrm{o}}$ 47, 2002.

KATZ, Peter. The New Urbanism Toward an Architecture of Community. McGraw Hill, Inc.1994.

KLEIN, Naomi. Sem Logo - A Tirania das Marcas em um Planeta Vendido. Rio de Janeiro: Editora Record, 2002.

LARA, Fernando. Vizinhos do Pateta. In. Arquitextos - periódico mensal de textos de arquitetura (online) Disponível: http://www.vitruvius.com. br (capturado em 29 jul 2002)

- Admirável Urbanismo Novo. In. Arquitextos - periódico mensal de textos de arquitetura (online) Disponível: http://www.vitruvius.com.br (capturado em 29 jul 2002)

LE CORBUSIER. Por uma Arquitetura. São Paulo: Editora Perspectiva, 2002.

LIPOVETSKY, Gilles. Os tempos hipermodernos. São Paulo: Barcarolla, 2004.

MACIEL, Kátia e PARENTE, André. Redes sensoriais: arte, ciência, tecnologia. Rio de Janeiro: Contra Capa, 2003.

MARX, Karl. Capital o Livro. São Paulo: Editora Civilização Brasileira, 1998.

MIDDLETON, Victor T. C. Marketing de turismo. Rio de Janeiro: Elsevier, 2002.

MOLES, Abraham. O Kitsch. São Paulo: Perspectiva, 2001.

MONTANER, Josep Maria. As formas do século XX. Barcelona: Gustavo Gili, 2002.

A Modernidade Superada. Arquitetura, arte e pensamento do séc XX. Barcelona: Gustavo Gili, 2001.

MORA, Joe. Disney's Dream Town. In. American Studies Today (online) Disponível: http://www.americansc.org.uk/Online/Celebration.htm (capturado em 10 jul 2005)

MORIN, Edgar. A inteligência da complexidade. São Paulo: Peirópolis, 2000.

NATIONAL AMUSEMENT PARK HISTORIC ASSOCIATION. The Amusement Park Industry - a Very Brief History (online). Disponível: http:// www.napha.org/history.html (capturado em 2 maio 2001)

NESBITT, Kate (org.). Uma Nova agenda para a arquitetura - Antologia Teórica 1965-1995. São Paulo: Cosac Naify, 2006.

NIELSEN, Christian. Turismo e Mídia: construção e destruição de destinos turísticos. São Paulo: Contexto, 2002.

NOVAES, Adauto (org.). O Olhar. Companhia das Letras. São Paulo:2003.

OECHSLIN, Werner, BUSCHOW, Anja. Architecture de Fête. Bruxelles: Pierre Mardaga editeur, 1984.

ORWELL, George. 1984. São Paulo: IBEP Nacional, 2003.

PARENTE, André. Tramas da rede: novas dimensões filosóficas, estéticas e políticas da comunicação. Porto Alegre: Sulina, 2004.

PADRÃO 7 estrelas. In. Anuário do Turismo Exame. edição 2007/2008. Editora Abril. Disponível online http://portalexame.abril.com.br/static/ aberto/turismo/anuario_exame_turismo/m0125855.html

POSTMAN, Neil. Amusing ourselves to death - Public Discourse in the age of show business. Penguin Books. New York:1986. 
ROGERS, Dorothy S., GAMANS, Lynda R., GRASSI, Mercia M.T. Retailing New Perspectives. 2 ed. Forth Worth: The Dryden Press, 1991.

RYBCZYNSKI, Witold. Casa: Pequena História de uma Idéia. Rio de Janeiro: Record, 1999.

SETTI, Adriana. Futurismo. In. Viagem e Turismo - Especial - Isto é Espanha, edição 151-E 05/2008. Editora Abril

SORKIN, Michael (Coord.). Variations on a Theme Park - The New American City and the End of Public Space. New York: Hill and Wang, 2001.

THE IMAGINEERS. Walt Disney Imagineering - A Bebind the Dreams Look at Making the Magic Real. New York: Disney Editions, 1996.

VARGAS, Heliana Comin. Espaço Terciário - o lugar, a arquitetura, a imagem do comércio. São Paulo: Editora SENAC, 2001.

VENTURI, Robert. Complexidade e Contradição em Arquitetura. São Paulo: Martins Fontes, 1995.

VENTURI, Robert, SCOTT BROWN, Denise, IZENOUR, Steven. Learning From Las Vegas - The Forgotten Symbolism of Architectural Form. Cambridge: The MIT Press, 2001.

WARD, Stephen. Time and place: key themes in place promotion in the US A, Canada and Britain since 1870. In. GOLD, John R. e WARD, Stephen V. (org.). Place Promotion The use of publicity and marketing to sell towns and regions. Chichester: John Wiley and Sons, 1994.

WOLFF, Janet. A Produção Social da Arte. Rio de Janeiro: Zahar Editores, 1982.

Obras consultadas AUGÉ, Marc. Não Lugares - Introdução à uma Antropologia da Supermodernidade. Campinas: Papirus, 1994.

BACHELARD, Gaston. A Poética do Espaço. São Paulo: Abril Cultural, 1978.

BAUDRILLARD, Jean. Disneyworld Company (online) Disponível: http:// www.uta.edu/english/apt/collab/texts/disneyworld.html (capturado em 27 nov 2002)

Simulacra and simulations (The body in theory: histories of cultural materialism). San Francisco: UMP, 1995.

CANCLINI, Nestor Garcia. Consumidores e Cidadãos. Rio de Janeiro: UFRJ Editora, 2005.

COBRA, Marcos. Marketing do entretenimento. São Paulo: Senac, 2008.

COLTMAN, Michael M. Tourism marketing. New York: Van Nostrand Reinhold, 1989.

DAVIDOFF, Doris S. e DAVIDOFF, Philip G. Sales and Marketing for Travel and Tourism. Englewood Cliffs: Prentice Hall, 1983.

DEBORD, Guy. A Sociedade do Espetáculo - Comentários sobre a Sociedade do Espetáculo. Rio de Janeiro: Contraponto, 1997.

FUÃO, Fernando Freitas (Coord.). Arquiteturas Fantásticas. Porto Alegre: Editora Universidade/ UFRGS, 1999.

HALL, C. M. Planejamento Turístico. Políticas, Processos e Relacionamentos. São Paulo: Contexto, 2001.

HERWIG, Oliver e HOLZHERR, Florian. Dream Worlds architecture and entertainment. Munich: Prestel Verlag, 2006.

HYTTINEN, Leena. Theme \& Amusement Parks in the U.S.A. (online) Disponível: http://www.uta.fi/fast/us7/paps/themeusa.html (capturado em 20 out 2002) 
HERTZBERGER, Herman. Lições de arquitetura. São Paulo: Martins Fontes, 1999.

JANSEN-VERBEKE, M. e LIEVOIS, E. Análise de Recursos Históricos para Turismo Urbano em Cidades Européias. In PEARCE, D. e BUTLER, R. (org.). Desenvolvimento em Turismo. Temas Contemporâneos. São Paulo: Contexto, 2002.

KOOLHAAS, Rem. Delirious New York, A retroactive manifesto for Manhattan. New York: Monacelli Press, 1978.

MENEZES, Ulpiano T. B. A Paisagem como Fato Cultural. In YÁZIGI, E. (org.). Turismo e Paisagem. São Paulo: Contexto, 2002.

MILLS, Steve. American Theme Parks and the Landscapes of Mass Culture. (online) Disponível: http://www.americansc.org.uk/disney.htm (capturado em 20 out 2002)

MONTANER, Josep Maria. Arquitetura y Crítica. Barcelona: Gustavo Gili, 1999.

NOISETTE, P. e VALLËRURGO, F. Le Marketing des Villes. Un Défi pour le Développement Strátegique. Paris: Les Ed. d'Organisation, 1996.

PARQUES ganham importância no cenário brasileiro. Entrevista com Francisco Carlos Lopes, presidente da Adibra Revista Hotel News (online) Disponível: http://www.revistahotelnews.com.br/ entrevista_296.htm (capturado em 20 out 2002)

POPE, N. W. Marketing do Mickey Mouse. In. American Banker, 12/09/1979.

POTTEIGER, Matthew e PURINTON, Jamie. Landscape Narratives : Design Practices for Telling Stories. Wiley, 1998.

RICHTER, L. e WALL, G. A Política de Desenvolvimento do Turismo Histórico: Temas Emergentes para o Novo Milênio. In PEARCE, D. e BUTLER, R. (org.). Desenvolvimento em Turismo. Temas Contemporâneos. São Paulo: Contexto, 2002.

RUSCHMANN, Doris. Marketing Turístico: um enfoque promocional. Campinas: Papirus, 1995.

RYKWERT, Joseph. A Casa de Adão no Paraíso. A Idéia da Cabana Primitiva na História da Arquitetura. São Paulo: Editora Perspectiva, 2003. A sedução do lugar: a história e o futuro da cidade. São Paulo: Martins Fontes, 2004.

SCHULTZ, Patricia. 1000 lugares para conhecer antes de morrer. Rio de Janeiro: Sextante, 2006.

SILVA, Maria da Glória Lanci da. Cidades turísticas: identidades e cenários de laz̧er. São Paulo: Aleph, 2004.

SUBIRATS, Eduardo. Desaprendendo com Las Vegas. In. Arquitextos periódico mensal de textos de arquitetura (online) Disponível: http:// www.vitruvius.com.br (capturado em 17 jul 2002)

TASCHEN, Angellika. (ed.) Fantasy Worlds. Köln: Taschen, 2007.

TEIXEIRA, Carlos Moreira. FCUK. In. Arquitextos - periódico mensal de textos de arquitetura (online) Disponível: http://www.vitruvius.com. br (capturado em 29 jul 2002)

VANDERBILT, Tom. On Place It's a Mall World After All-Disney, Design, and the American Dream. In. Harvard Design Magazine (online) Disponível: http://www.gsd.harvard.edu/research/publications/hdm/ back_issues/9onplace_vanderbilt.html (capturado em 20 out 2002) 
Websites consultados http://villette.com (capturado em 14 fev 2005)

http://whc.unesco.org/en/list/483 (capturado em 05 set 2007)

http://www.aoc.gov (capturado em 05 ago 2007)

http://www.americansc.org.uk/Online/Celebration.htm (capturado em 10 jul 2005)

http://www.barraworld.com.br (capturado em 05 maio 2007)

http://www.bergisel.info (capturado em 05 jun 2008)

http://www.bigthings.ca/ontario/colborne.html (capturado em 15 mai 2003)

http://www.brastemp.com.br (capturado em 13 nov 2007)

http://www.burjdubai.com (capturado em 08 set 2008)

http://www.caesars.com (capturado em 07 jun 2005)

http://www.celebrationfl.com (capturado em 12 jul 2005)

http://www.circuscircus.com (capturado em 07 jun 2005)

http://www.cite-musique.fr (capturado em 08 maio 2005)

http://www.cnca.gob.mx/cnca/inah/zonarq/chichen.html (capturado em 03 set 2007)

http://www.disney.co.hk (capturado em 08 maio 2005)

http://www.disneylandparis.com.fr (capturado em 20 jun.2003)

http://www.disneyland.disney.go.com (capturado em 20 maio 2003)

http://www.disneypix.com (capturado em 10 jul 2005)

http://www.dubailand.com.ae (capturado em 15 jul 2008)

http://www.estrela.com.br/estrela (capturado em 18 jan 2006)

http://www.excalibur.com (capturado em 07 jun 2005)

http://www.feiradobordadodeibitinga.com.br (capturado em 15 jul 2008)

http://www.ferrero.com.br (capturado em 06 ago 2008)

http://www.fiftiesweb.com/tv/davy-crockett.htm (capturado em 10 ago 2008)

http://www.goldennugget.com (capturado em 08 jun 2005)

http://www.hardrock.com (capturado em 18 out 2006)

http://www.holambra.sp.gov (capturado em 10 jul 2008)

http://www.hopihari.com.br (capturado em 30 nov 2007)

http://www.innsbruck-tourism.at (capturado em 05 jun 2008)

http://www.justdisney.com/ walt_disney/quotes (capturado em 10 jul 2002)

http://www.knotts.com (capturado em 19 jun. 2005)

http://www.lojavirtual/rainhaautentico.com.br (capturado em 14 mar 2008)

http://www.luxor.com (capturado em 07 jun 2005)

http://www.luxurydisneyguide.com (capturado em 09 jul 2005)

http://www.magictoys.com.br (capturado em 14 mar 2008)

http://www.marilan.com.br (capturado em 13 mar 2008)

http://www.minutemaid.com.br (capturado em 13 mar 2008) 
http://www.natura.com.br (capturado em 28 out 2008)

http://www.nba.com (capturado em 23 set 2006)

http://www.nettv.globo.com (capturado em 08 ago 2008)

http://www.nielsenmedia.com (capturado em 18 abr 2008)

http://www.nike.com (capturado em 18 ago 2006)

http://www.niteroitv.com.br/guia/pontosturisticos.asp?pos_menu=\# (capturado em 05 jul 2008)

http://www.nordpark.com (capturado em 05 jun 2008)

http://www.nps.gov/thje/ (capturado em 05 ago 2007)

http://www.nps.gov/nr/travel/wash/lenfant.htm (capturado em 06 ago 2007)

http://www.nynyhotelcasino.com (capturado em 08 jun 2005)

http://www.oautentico.com.br (capturado em 14 mar 2008)

http://www.patydoalferes.rj.gov.br (capturado em 15 jul 2008)

http://www.pritzkerprize.com (capturado em 05 jun 2008)

http://www.ryanair.com (capturado em 03 nov 2008)

http://www.reef.com (capturado em 07 out 2008)

http://www.salzburg.info (capturado em 13 mai 2007)

http://www.sixflags.com (capturado em 18 jun. 2003)

http://www.sobral.ce.gov.br (capturado em 04 mai 2008)

http://www.submarino.com.br (capturado em 08 ago 2008)

http://www.thepalm.ae (capturado em 15 jul 2008)

http://www.thevenetian.com (capturado em 10 out 2007)

http://www.theworld.com.ae (capturado em 15 jul 2008)

http://www.turismoholambra.com.br (capturado em 10 jul 2008)

http://www.universalstudios.com/themeparks (capturado em 27 mar 2007)

http://www.venetianmacao.com (capturado em 11 ago 2008)

http://www.venusfort.co.jp (capturado em 09 ago 2008)

http://www.visitcostarica.com (capturado em 03 fev 2008)

http://www.weguide.com.br (capturado em 18 jan 2002)

http://www.yucatantoday.com (capturado em 05 set 2007)

http://www.zaragoza.es (capturado em 20 mai 2008)

Outros meios Lost Terceira Temporada Completa. Buena Vista Home Entertainment, 2007. (989 min) DVD 7 vol.

Pequenos grandes consumidores. CBC. documentário exibido em 07 de agosto de 2008 no canal à cabo GNT.

Casablanca. Warner Bros./Metro-Goldwyn-Mayer, 1942. Direção Michael Curtis (103 min) DVD

Quero ser Grande - Big. Gracie Films, 1988. Direção. Penny Marshall (98 minutos) DVD.

A Noviça Rebelde - The Sound of Music. 20th Century Fox,1965. Direção Robert Wise (172 min) DVD 